\title{
EXPLORING ANTI-DEMOCRATIC PRACTICES IN UNIVERSITY POLICY-STEERAGE, MANAGEMENT AND GOVERNANCE IN MalaWI: A CRITICAL THEORY APPROACH
}

BY

\section{Lester Brian Shawa}

\author{
A thesis \\ submitted to the Victoria University of Wellington \\ in fulfilment of the requirements for the degree of \\ Doctor of Philosophy
}

Victoria University of Wellington

2011 



\begin{abstract}
This thesis draws on Critical Theory as advanced by Critical Theorists in the tradition of the Frankfurt School to explore the nature of anti-democratic practices within policy-steerage, management and governance of university education in Malawi. The thesis critiques instrumental use of reason and neopatrimonial aspects that permeate policy-steerage, management and governance of the university sector in Malawi, and suggests ways of emancipation or social change.
\end{abstract}

Two philosophical ideas inform analysis of this emancipatory project: dialectical reasoning as advanced by the first generation Critical Theorists such as Horkheimer, Adorno and Marcuse and communicative rationality, which is complemented by the theory of the lifeworld as advanced by the second generation Critical Theorist, Habermas. Dialectical reasoning entails understanding things as they are now and what they might be in future, as such, it is a useful idea for emancipation in that it fosters constant questioning (reflexivity) on the part of actors to make things better. Communicative rationality entails that actors seek to reach common understanding and coordinate actions by reasoned arguments, consensus and cooperation rather than instrumental reasoning and is useful for attaining social change (Habermas, 1984, 1987). Data sources comprise global policy debates, policy documents and interviews with selected government policymakers, Malawian civil society, university administrators and leaders of university staff and student unions.

The thesis reveals that at international policy-steerage level, university policymaking in Malawi is chiefly orchestrated by the World Bank using its economic power and the global-neoliberal logic. In this logic, Malawi follows the dictates of the powerful World Bank. Thus, the argument presented is that the World Bank's university policy-steerage in Malawi follows instrumental rationality and 
is anti-democratic. Instrumental reasoning refers to the deliberate use of the power of reason for social control or manipulation. At university level, the thesis reveals a rivalry relationship among stakeholders which leads to constrained collegial governance. The thesis shows that the neopatrimonial attitude of presidentialism or the big-man syndrome, which permeates the management and governance of universities in Malawi, perpetuates instrumental use of reason and renders the system anti-democratic. At Malawi Government university policy-steerage level, the thesis shows problems associated with the usage of power by state presidents who are also chancellors of public universities. At this level, policy-steerage is interventionist and characterised by both neopatrimonial aspects of the big-man syndrome and patron-client relationships that lead to instrumental use of reason.

Based on this Critical Theory analysis, a theory of university management and governance for Malawian universities is presented aimed at achieving emancipation. To achieve social change there is a need to challenge instrumental ways of reasoning and neopatrimonial aspects by employing dialectical reasoning and communicative rationality. 


\section{Acknowledgements}

I am indebted to my supervisors Dr. Stephanie Doyle and Prof. Robert Strathdee for guiding me throughout this thesis. I have immensely benefitted from their intellectual prowess and thorough critique throughout the production of the thesis. The two academics complemented each other in their expertise and guidance in ways that were most favourable to me.

To two anonymous reviewers of my $\mathrm{PhD}$ proposal, I pay tribute for their critique and suggestions that allowed me to forge ahead with my PhD studies. I would like to wish them success in their academic endeavours.

It would have been impossible for me to come and study in New Zealand if the Victoria University of Wellington did not award me the prestigious Doctoral Scholarship. As such, I would like to register my appreciation to the Victoria University Scholarship Committee for providing me with the required funding for my studies.

Working at the School of Education Policy and Implementation (SEPI) as both tutor and researcher has been a great experience. These activities have contributed immeasurably to my academic and professional growth while studying at Victoria University. I thus, thank the head of SEPI, Prof. Strathdee and all those concerned for creating an enabling work environment for me.

Many thanks are due to all postgraduate administrative office personnel for providing all the necessities during my $\mathrm{PhD}$ study period. I do not take their contribution for granted. 
I sincerely thank the management of Mzuzu University, my employer, for providing me a chance to pursue further studies amidst shortage of staff in the department of Education and Teaching Studies.

I am grateful to all academics and friends, numerous to mention who have contributed to my studies in their own different ways. May God bless their activities.

My brothers and sisters provided me with all the support that I needed to go through my studies far away from home. I cherish their love and support and pray that God continues to bless their efforts.

Lastly, but not least, I would like to thank the Lord for sustaining me in my studies. Icho mwenecho Chiuta walata munthu ni njani? "Whatever God has desired to achieve, who is man (to change)?" 


\section{Dedication}

To Stanslas, Theresa, Francis, Salome, Gertrude, Nicholas, Isabel, Karen, Timothy, Ken and all Philosophers and Sociologists of Education employing Critical Theory to make university policy-steerage, management and governance a democratic affair. 


\section{Table of Contents}

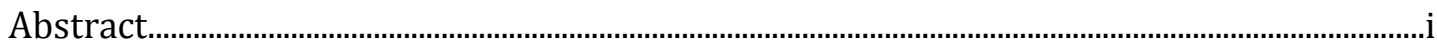

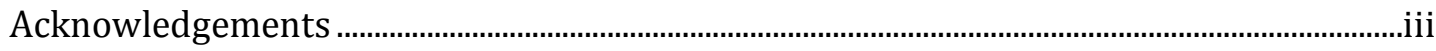

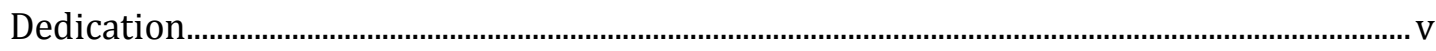

Table of Contents ..............................................................................................................................

CHAPTER 1 Critical Theory and the nature of the study ............................... 1

1.1. Introduction

1.2. The research problem and research question ........................................................................

1.2.1. The research objective and questions..................................................................... 9

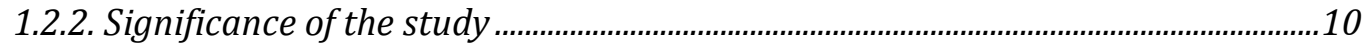

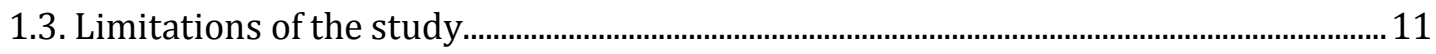

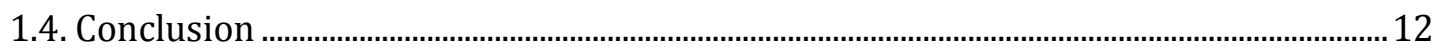

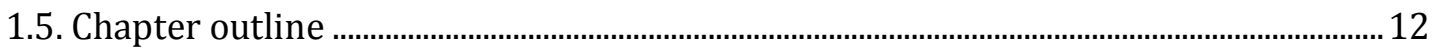

CHAPTER 2 Regionalist politics and neopatrimonialism in Malawi ........... 17

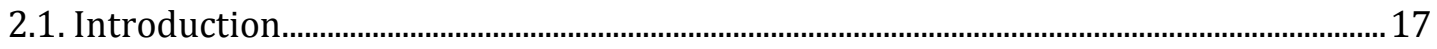

2.2. Politics and the crystallisation of regionalist practices in Malawi ................................... 18

2.3. Conceptualising neopatrimonialism................................................................................. 23

2.3.1. Neopatrimonialism in the socio-political life of Malawi...........................................27

2.3.2. Neopatrimonialism under one-party and multi-party periods ..............................28

2.4. The primacy of regionalism and neopatrimonialism in Malawi ...................................... 33

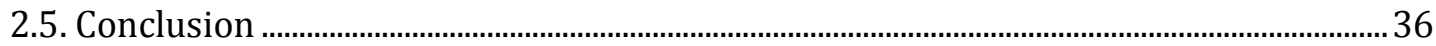

CHAPTER 3 Critical Theory as theoretical framework ............................... 38

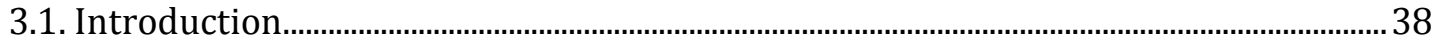

3.2. Definition of a paradigm or theoretical framework............................................................. 39 


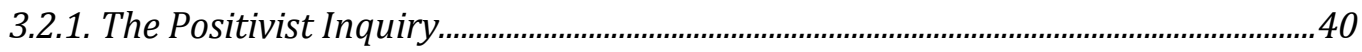

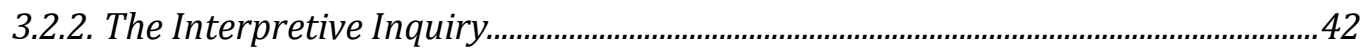

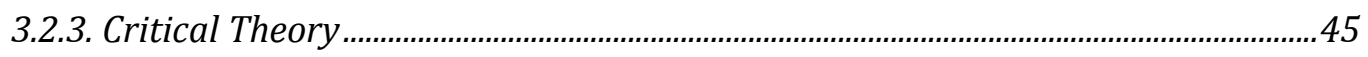

3.3. Critique for first generation Critical Theorists................................................................ 47

3.3.1. Challenges to the Hegelian-Marxian view of critique ................................................49

3.3.2. Horkheimer and Adorno's latter pessimism of reason and critique.......................50

3.4. Critique, a Habermasian linguistic turn ........................................................................... 51

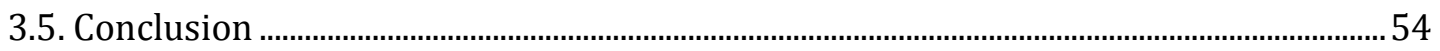

CHAPTER 4 Challenges of the university sector in Malawi ......................... 55

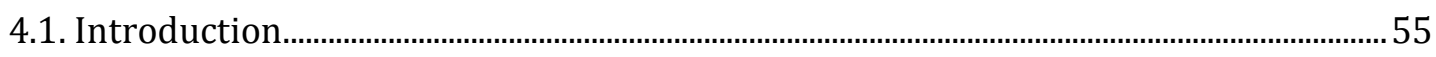

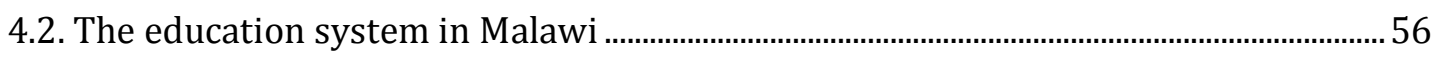

4.3. Education policy in Malawi................................................................................................. 56

4.4. Challenges of the university sector in Malawi ................................................................... 57

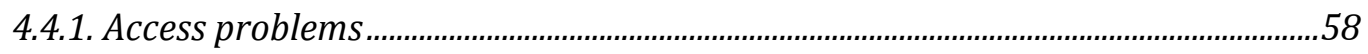

4.4.2. Problems of quality-provision of university education ..............................................61

4.4.3. Problems of management and governance of the university sector ......................62

4.4.4. Problems of financing university education ..............................................................63

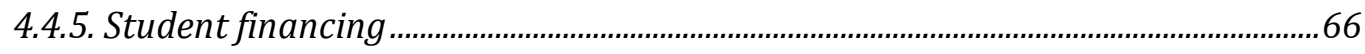

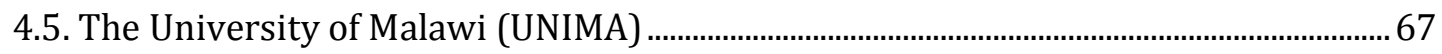

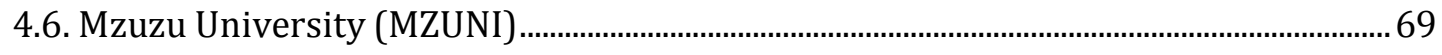

4.7. The University of Livingstonia (UNILIA) ......................................................................... 70

4.8. The Catholic University of Malawi (CUNIMA) ................................................................. 71

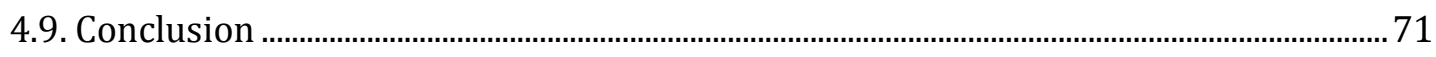




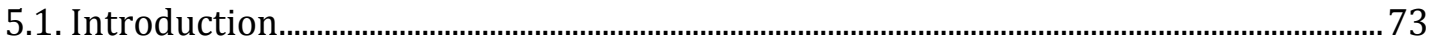

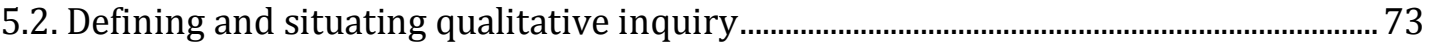

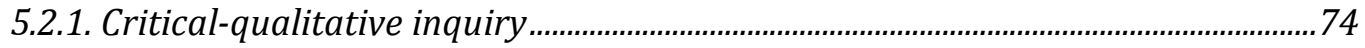

5.2.2. The role of reflexivity in critical-qualitative research …...........................................75

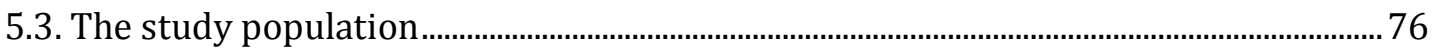

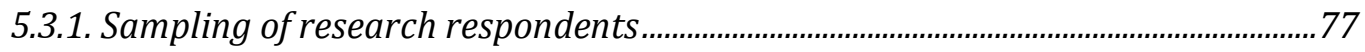

5.3.2. Research population from the Malawi Government.................................................77

5.3.3. Research population from the university sector .......................................................78

5.3.4. Research population from other Civil Society Organisations...................................79

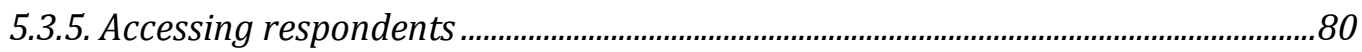

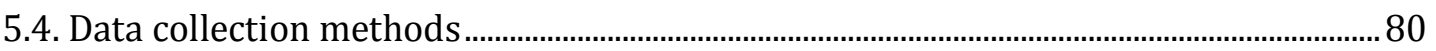

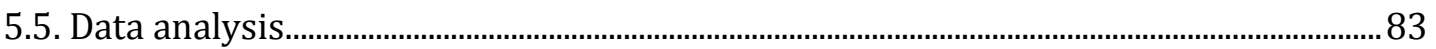

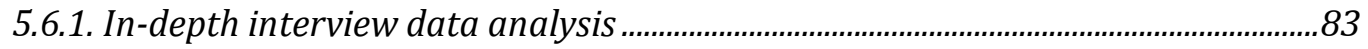

5.6.2. Conceptual analysis and policy document analysis.................................................8

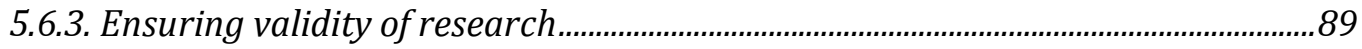

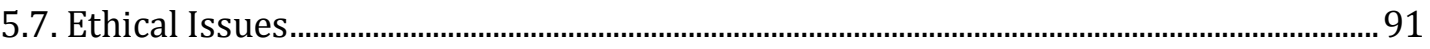

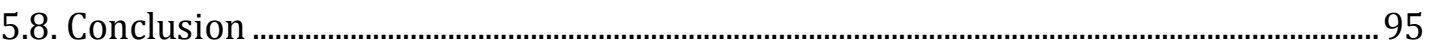

CHAPTER 6 The World Bank and university education policy in Africa.... 96

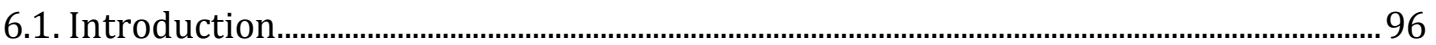

6.2. Conceptualising policy ………………………......................................................................

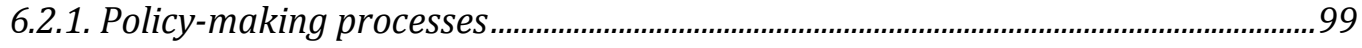

6.3. Conceptualising globalisation ............................................................................................101

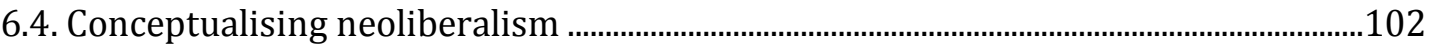

6.5. The World Bank's involvement in education policy in Africa...........................................103

6.5.1. African developmental university and manpower planning .................................105 
6.5.2. The basic education priority

6.6. Structural Adjustment Policies and education in Africa.

6.7. The Post-Washington Consensus

6.8. The Knowledge economy

6.9. The World Bank's influence on [education] policy...

6.10. Conclusion 116

CHAPTER 7 Global changes in university governance and its impact on Malawi 117

7.1. Introduction 117

7.2. Evidence of changes toward the new-managerialism in Malawi. 118

7.3. Global policy-steerage and university governance in Malawi

7.3.1. The state-control model and university governance in Malawi.. 120

7.3.2. The state-supervisory model and university governance in Malawi. 121

7.4. The nature of university governance in Malawi.

7.5. The emerging new-managerialism in Malawian universities 123

7.5.1. Critique of the new-managerialism in university governance. 124

7.6. Conclusion 127

CHAPTER 8 Governance and administrative practices at university level in Malawian universities. 129

8.1. Introduction 129

8.2. Rivalry relationship among university stakeholders 130

8.2.1. Strife between academics and university administrators.. 130

8.2.2. Strife between students and university managers.. 142

8.2.3. Strife between students and academic staff. 149

8.3. Constrained collegial decision-making processes at universities 151

8.4. Conclusion 159 
9.1. Introduction 160

9.2. The state president as chancellor of public universities 161

9.3. The big-man syndrome and patron-client mechanisms 169

9.4. The quota policy-making process

9.5. The big-man syndrome and academic freedom in Malawi 184

9.6. Conclusion .186

CHAPTER 10 International forces in university-policy-steerage in Malawi.. 187

10.1. Introduction 187

10.2. The World Bank as determiner of university policy in Malawi 187

10.3. The World Bank's influence through the Malawi Government. 192

10.4. The Poverty Reduction Strategy Paper and the university. 194

10.5. Conclusion

CHAPTER 11 Respondents' views on improving the management and governance of the university sector in Malawi ........................................ 200

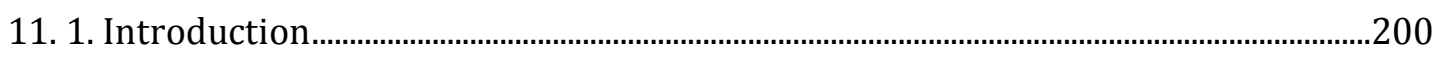

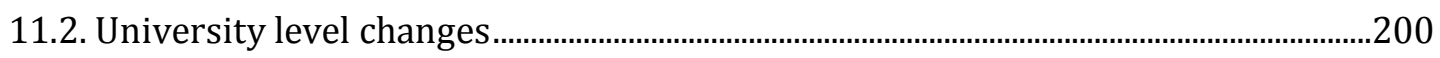

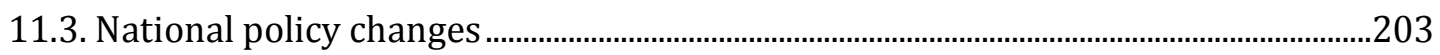

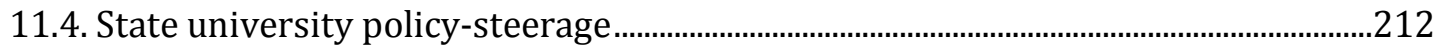

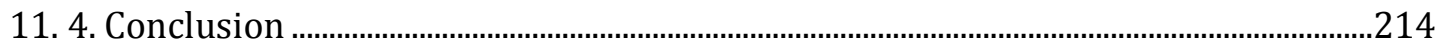

Chapter 12 Toward Emancipation: A theory of university management and governance for Malawian universities based on Critical Theory .............. 216

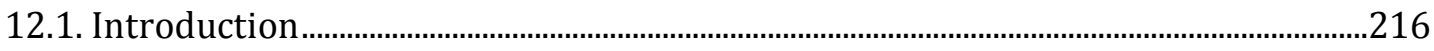

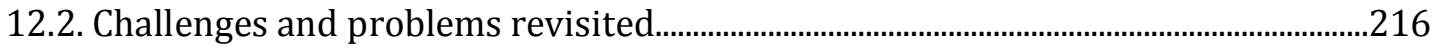


12.4. A theory of university management and governance.

12.4.1. Emancipation at international level.

12.4.2. Emancipation at university level. 226

12.4.2. Emancipation at Malawi Government level. 228

12.4.4. Summary of the emancipatory promise. 230

12.5. Issues for further research 232

12.6. Final word 232

REFERENCES

\section{APPENDICES}

Appendix 1: An example of an invitation letter for research

Appendix 2: Consent Sheet.

Appendix 3: An example of research information sheet 256

Appendix: 4: Sample questions for vice chancellors, public universities. 259

Appendix 5: Sample questions for chairpersons of staff unions 260

Appendix 6: Sample questions for chairpersons of student unions. 261

Appendix 7: Questions for the Director of Development 262

Appendix 8: Sample questions for university registrars and principals 263 Appendix 9: Questions for the Director of Higher Education 264

Appendix 10: Sample questions for vice chancellors, private universities. 265

Appendix 11: Questions for the civil society 266 Appendix 12: University of Malawi selection by district, year and population from 2002-2008. 267 Appendix 13: Public Affairs Committee (PAC) press statement 269 Appendix 14: Church of Central Africa Presbyterian Synod of Livingstonia press release 
Appendix 15: Quota university policy selection directive

Appendix 16: call for academic freedom by top Malawian Professors.

Appendix 17: Council for the Development of Social Science Research in Africa's concerns over academic freedom in Malawi 276

Appendix 18: Demonstration in fight for academic freedom at Chancellor College, University of Malawi

Appendix 19: Chairperson of the University of Malawi Council's view on academic freedom. 282

\section{List of Tables}

Table 1: Presidential election results in 1994 (major candidates only) ................................ 34

Table 2: Presidential election results in 1999 (major candidates only) ................................. 35

Table 3: Presidential election results in 2004 (major candidates only) .................................. 35

Table 4: Presidential election results in 2009 (major candidates only) .................................36

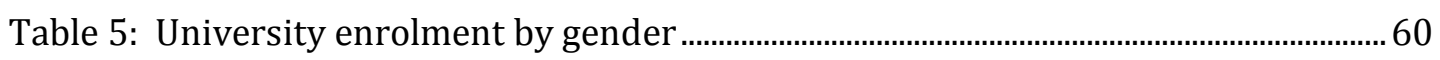

Table 6: The University of Malawi funding from 1999/2000-2004/2005 ...........................65

Table 7: Staff profile at the University of Malawi in 2008

Table 8: Staff profile at Mzuzu University in 2008

Table 9: Staff profile at the Catholic University of Malawi in 2008 ………………................. 71

\section{List of Figures}

Figure 1: Political Map of Malawi showing regions: Northern, Central and Southern .... 18 


\section{CHAPTER 1}

\section{Critical Theory and the nature of the study}

\subsection{Introduction}

"Critical theory" is a broad term that is employed differently by philosophers and sociologists as well as scholars of related disciplines such as Public Policy (How, 2003). While drawing on "critical theory" in general, this thesis adheres more to the version that was developed by the Institute for Social Research in Frankfurt, Germany (referred to as the Frankfurt School) from the 1920s and redefined by Habermas from the 1960s (Bohman, 1996; How, 2003; Morris, 2006, 2009; Rehg, 1996). Throughout this thesis, this version is written with capital letters as in Critical Theory to depict greater adherence to the Frankfurt School as opposed to the general usage of the phrase written without capital letters as in critical theory (Bohman, 1996; How, 2003).

Philosophers and sociologists working within Critical Theory are, among other things, interested in exposing anti-democratic social practices so as to emancipate societies (Habermas, 1984, 1987, 1998; Horkheimer, 1978; How, 2003; Marcuse, 1941, 1978; Rasmussen, 1996, 2004; Rehg, 1996). Similarly, this thesis draws on Critical Theory to explore the nature of anti-democratic practices within policy-steerage, management and governance of university education in Malawi at international, university and government levels and suggest ways of emancipation or social change. For example, given that during the dictatorship era (1964-1994) the university sector suffered both physical and symbolic violence (Habib, Morrow, \& Bentley, 2008; Kerr \& Mapanje, 2002; Sturges, 1998) and that in 1994 the country embraced multiparty democracy, such an analysis is required in order to determine the nature of anti-democratic practices within the new era. A democratic culture in policy- 
steerage, management and governance of university education in Malawi is essential for a responsible citizenry as well as for the developmental needs of the country. In exploring the nature of anti-democratic practices within the university sector, the thesis draws on global policy debates or discourses, policy documents and interview data from perspectives of selected government policymakers in Malawi, selected Malawian civil society, university administrators/managers and students in Malawian universities. In doing so, this thesis addresses a gap in our knowledge about the nature of antidemocratic practices within policy-steerage, management and governance of university education in Malawi and in suggesting ways of emancipation or social change.

Horkheimer argued that Critical Theory is adequate only if it meets three criteria:

...it must be explanatory, practical, and normative, all at the same time. That is, it must explain what is wrong with current social reality, identify actors to change it, and provide both clear norms for criticism and practical goals for the future (Bohman, 1996, p. 190).

The framework provided by Horkheimer provides structure to this thesis. Thus, following on from Horkheimer, this thesis attempts to examine problems within the current practice of university policy-steerage, management and governance; identify actors to solve the problems and provide ways of how to improve policy-steerage, management and governance of university education in Malawi (Bohman, 1996). Ultimately, the thesis attempts to develop a theory of university management and governance for Malawian universities based on Critical Theory.

In this thesis, the notions of management and governance encompass internal and external university relationships (Marginson \& Considine, 2000). These relationships within and outside the university include acts of influence or power within universities and in their interaction with the Malawi Government and the international community (see Marginson \& Considine, 
2000). The notion university policy-steerage thus, denotes the influence or power exerted by the Malawi Government and the international community in the management and governance of universities in Malawi. The broad perspective on university management and governance adopted in this thesis makes it possible for the thesis to explore the nature of anti-democratic practices within policy-steerage, management and governance of university education in Malawi at international, university and government levels and suggest ways of emancipation or social change. It is important to explore these issues since universities are positioned within wider power relationships (see Kolsaker, 2008; Ordorika, 2003; Rytmeister \& Marshall, 2007). As such, exploring such issues could help the university to mould reflective future leaders.

Critical Theory has been contentious among its proponents starting from its first generation theorists such as Horkheimer (1895-1973), Marcuse (18981979) and Adorno (1903-1969) to the second generation represented by Habermas (1929-) and his associates (Bohman, 1996; How, 2003; Morris, 2006; Rasmussen, 1996, 2004; Rehg, 1996). However, one aspect that sustains the project is the idea that Critical Theory ought to be critical, that is, it should not just interpret social reality correctly but create social and political conditions that make the human condition better or emancipated (Habermas, 1984, 1987, 1998; How, 2003; Neuman, 2006; Willis, Jost, \& Nilakanta, 2007). To emancipate society, Critical Theory challenges instrumental reasoning and its aims for social control and manipulation (Habermas, 1987; Horkheimer, 1978; Marcuse, 1941, 1978; Waghid, 2003). The phrase, instrumental reasoning, was coined by Horkheimer to mean purposive reason, more oriented to means to the exclusion of ends (Habermas, 1984, 1987; Rasmussen, 2004). Instrumental reasoning is, as such, used to explain the deliberate use of reason to manipulate society and exert power for social control. As suggested above, for this thesis to be genuinely critical the aim is to go beyond mere interpretation of the nature of anti-democratic practices within policy-steerage, management and governance of university education in 
Malawi to suggesting ways of emancipation or social change. To achieve the required social change in Malawian universities, this thesis develops a theory of university management and governance in chapter 12 , based on insights from Critical Theory.

In its analysis, the thesis employs both ideas of dialectical reasoning (the idea that an element in the process is presupposed by and contains an opposing element as part of its own identity without wedding it to the Marxian notion of historical materialism ${ }^{1}$ ) as developed by the first generation Critical Theorists and communicative rationality as advanced by Habermas in which democracy and social justice are embedded in reason giving in an intersubjective way (Habermas, 1984, 1987; Rasmussen, 1996, 2004; Rehg, 1996). Dialectical reasoning, as argued by Marcuse, entails that one sees "how things come to be the way they are and what they might be in the future" (How, 2003, p. 3). For example, human justice ought to be seen as having potential to become better than it may be in its present (what it is now) (How, 2003). Opposed to critique in dialectical reasoning, Habermas' communicative rationality is postmetaphysical and is embedded in language (Morris, 2006, 2009; Rehg, 1996). However, although these ideas have different normative foundations regarding the nature of critique, this study finds both useful in exploring the nature of anti-democratic practices within policy-steerage, management and governance of university education in Malawi and in suggesting ways of emancipation or social change such as by developing a theory of university management and governance for Malawian universities.

As elaborated in the chapter, the thesis conceptualises democratic within university management and governance in Malawi, using Critical Theory's

1Wedding the "dialectical" to the Marxian notion of historical materialism meant that emancipation was aligned to the history of human production and the idea of setting the proletariat free as a species being. Rather than seeing emancipation in this limited view, the thesis sees the idea in a wider sense. 
ideas of dialectical reasoning and communicative rationality. This means that democratic policy initiatives and practices are those that follow or give room to these major ideas. Waghid summarises the idea of the "democratic" within Critical Theory especially as viewed in the Habermasian sense as follows:

using and creating conditions for self reflexive critique, replacing
distorted education policies, discouraging indoctrination and
domination, freeing educational institutions from bureaucratic
interests, re-theorizing the roles of ego-centric members, producing
and reproducing more rational and informed educational policy rules
and offering guidance and new knowledge in education policy
formulation (Waghid, 2003, p. 52).

Thus, while not employing positivist logic, analysis of university policysteerage, management and governance in Malawi, in this thesis, follows the democratic view presented by Critical Theory as advanced by Waghid (2003) above.

This thesis follows a wide range of studies. Critical Theory has been applied to many fields such as public policy, planning and practice (Forester, 1993; Hartz-Karp, 2007) and education (Fritzell, 2002; Reich, 2007; Van Wyk, 2006; Waghid, 2003, 2004, 2005, 2006; Weaver \& Olson, 2006). For example, for Forester (1993), Critical Theory has offered insights into methodological problems of assessing planning, policy and administrative issues. He argues that the legacy of Critical Theory and especially the work of Habermas, "challenges policymakers to devise methods of investigation that are empirically sound and descriptively powerful, interpretively plausible and phenomenological meaningful and yet critically pitched" (Forester, 1993, p. 2). He contends that Habermas's lifeworld analysis enables policymakers to investigate how institutional pressures work "through the media of power and money, bureaucratisation and commodification, to pre-empt or encroach upon autonomous or even tradition-appropriating social action" (Forester, 1993, p. 4). Similarly Hartz-Karp (2007), using Critical Theory, argues that deliberative engagement successfully guided the Australian government policy in the Department of Planning and Infrastructure. Applying Critical Theory in his 
conceptual study of higher education transformation in South Africa, Van Wyk (2006) argues that a Critical Theory analysis shows that apartheid education aimed at making Black South Africans subservient and rendered them uncritical, as such, the role of the university both at policy and pedagogy is to emancipate the minds of South Africans especially Blacks to be self critical. All in all, these studies exemplify the application of Critical Theory as an emancipatory paradigm. Whereas there have been different ways in which Critical Theory has been applied, studies exploring anti-democratic practices within particular systems of higher education at international, university and government policy-steerage levels are generally missing and are specifically absent in Malawian higher education. This thesis, thus, fills a major gap in the application of Critical Theory to policy-steerage, management and governance of higher education generally and particularly in Malawi.

The thesis presents the following arguments: First, that at international policysteerage level, university policy-making in Malawi is chiefly orchestrated by the World Bank using its economic clout and the neoliberal logic. In this logic, Malawi follows dictates of the "powerful" World Bank. Thus, the argument presented is that the World Bank's university policy-steerage in Malawi follows instrumental rationality and is anti-democratic. Second, that at university level a rivalry relationship among stakeholders leads to constrained collegial governance. At this level, the neopatrimonial attitude of presidentialism or the big-man syndrome permeates the management and governance of universities in Malawi and perpetuates instrumental use of reason to render the system anti-democratic. Third, that at Malawi Government university policy-steerage level, there are problems associated with the usage of power by state presidents who are also chancellors of public universities. At this level, policy-steerage is interventionist and characterised by both neopatrimonial aspects of the big-man syndrome and patron-client with regionalist facets that lead to instrumental use of reason. Fourth, that to bring about social change or emancipation there is a need for employing dialectical reasoning and communicative rationality within university policy- 
steerage, management and governance in Malawi. Following is a brief description of the research problem and question.

\subsection{The research problem and research question}

Since the 1990s, Malawi started developing policy texts for the education sector (including the university sector) as evidenced by documents such as the Vision 2020, the Policy and Investment Framework, the National Education Sector Plan and the Malawi Growth and Development Strategy (Malawi Government, 2000a, 2000b, 2006a, 2006b). However, while the country has embarked on developing university education policies to improve the sector, no substantial efforts to explore the nature of anti-democratic practices within the university sector are evident. Exploring anti-democratic practices in the university sector with the aim of offering social change is pertinent if the country is to fulfil its ambitions of using the sector, for example, to fulfil its development goals, which it is struggling to achieve (see Malawi Government, 2000a; Malawi Government, 2000b, 2006a).

Besides the development imperative, questioning how African governments arrive at university policy decisions, or choose among competing alternatives is an area that is little studied and consequently not understood in subSaharan Africa including Malawi (Saint, 2004). Saint observes the lack of rigorous studies concerning the leadership and management of university education arguing that "addressing the need for leadership and management is...a necessary condition for meeting the other challenges faced by African universities" (Saint, 2004, p. 64). In Malawi, there has been little critical analysis of university education and the interaction between the Malawi Government and international forces. 
Most studies on sub-Saharan African university education including Malawi, have concentrated on positivist or measurable challenges facing the sector such as access, the growth of private universities, financing and curriculum (see Assié-Lumumba, 2005, 2006; Banya, 2001; Banya \& Elu, 2001; Bloom, Canning, \& Chan, 2006; Bloom \& Rosovsky, 2007; Ishengoma, 2004; Johnstone, 2004; Levy, 1999, 2007; Ramphele, 2004; Teferra \& Altbach, 2004) with little or no attempt to employ critical methodologies that assess policy issues at macro levels and go beyond nomothetic stances of positivist theorising (see Carr \& Kemmis, 1986; Waghid, 2003). Positivist theorising has, thus, arguably deterred education policymakers in Malawi from critically engaging with issues that are not easily measurable and has hindered them from critically assessing macro issues affecting university management and governance in Malawi. Generally, studies on democratic education in Africa have emphasised citizenship education in terms of curriculum and pedagogy (Enslin, Pendlebury, \& Tjiattas, 2001; Fritzell, 2002; Reich, 2007; Waghid, 2003, 2004, $2005,2006)$ with little emphasis on democratic praxis in relation to internal and external university relationships in terms of policy-steerage, management and governance of university education.

Consequently, in Malawi critical policy studies are scarce both at university and government policy-steerage levels. While, at university level, Malawi like many African countries continues to experience frequent campus tensions among students, university administrators and managers and academic staff (Nur-Awaleh \& Mtegha, 2005; Sawyerr, 2004b; Teferra \& Altbach, 2004), there seems to be a lack of engagement such as in employing Critical Theory to ascertain causes of strife and suggest tangible ways for emancipation. At state university policy-steerage levels, it is surprising that there is a lack of research that hinges on exploring the nature of anti-democratic practices within Malawi Government university policy-steerage, given that historically under the authoritarian rule of Dr. Kamuzu Banda and the Malawi Congress Party the university sector was suppressed (Kerr \& Mapanje, 2002). A case in point is the 1965 Public Security Regulations which made it an offence, punishable by 
up to five years imprisonment to publish anything likely to undermine the authority of or public confidence in the government (Sturges, 1998). The University of Malawi under Banda experienced both physical and intellectual oppression. Habib et al., (2008, p. 143) argue that under Banda: "the churches were suborned and silenced, the legal profession was undermined by cowed and easily manipulated traditional courts and academics considered subversive were summarily expelled if expatriates, or imprisoned if Malawians".

Research that explores the nature of anti-democratic practices within the university sector in Malawi to suggest ways of emancipation or social change is, thus, imperative to foster values of democracy that may be stifled under the current multiparty democratic government. At international university policysteerage level, while literature reveals the negative influence of the World Bank in developing countries (Brock-Utne, 1996, 2003; Tilak, 2005), in Malawi the international influence has not rigorously been assessed using Critical Theory. All in all, this thesis contributes knowledge in understanding the nature of anti-democratic practices in university policy-steerage, management and governance by assessing them at three fronts: international, university and government levels so as to offer suggestions for social change based on Critical Theory. The research question is discussed next.

\subsubsection{The research objective and questions}

The research objective and questions in this thesis adhere to Critical Theory. Carr, (2000, p. 209) posits that: "Critical Theory separates itself from both functionalist/objective and interpretive practical sciences through critical epistemology that rejects the self-evident nature of reality and acknowledges the various ways in which reality is distorted". With this critical epistemology as background, the thesis conceived the following research objective: 
To explore the nature of anti-democratic practices within university policy-steerage, management and governance in Malawi at international, university and government levels with the aim of suggesting ways of emancipation.

This research objective was phrased in the following two related research questions:

1. What is the nature of anti-democratic practices in university policysteerage, management and governance in Malawi at international, university and government levels?

2. What nature of social change or emancipation is required in university policy-steerage, management and governance in Malawi at international, university and government levels?

\subsubsection{Significance of the study}

This thesis is significant in several ways. The thesis adds new knowledge in many ways: First, it contributes to the development of Critical Theory and its practical application. For example, while most Critical Theorists tend to favour either dialectic reasoning or communicative rationality, in employing both critiques, the thesis shows that despite having different normative foundations, these critiques can be complementary depending on problems to be researched. Thus, drawing on both critiques shows that within the development and application of Critical Theory one can tap on both older and newer critiques to solve particular research problems. It can be said that the thesis exposes the fallacy that the newer the critique the better it is. Second, using Habermas' theory of the lifeworld it adds new knowledge in understanding how the normative or the taken-for-granted phenomena such 
as neopatrimonialism and regionalism ingrained in societies, can permeate institutions such as universities in Malawi. Through the lifeworld analysis, the thesis shows that neopatrimonialism and regionalism uncritically influence practices of actors especially leaders of the universities (see Habermas, 1984, 1987). Third, it adds new knowledge to understanding how Critical Theory as an emancipatory theoretical framework or paradigm can help to assess the nature of anti-democratic practices within an education system such as in Malawi (see Bolton, 2005; Forester, 1993; Fritzell, 2002; Gutman \& Thompson, 2004; Habermas, 1987; Weaver \& Olson, 2006). Fourth, by advancing the use of dialectic reasoning and communicative rationality in university sector in Malawi, the thesis exposes how usage of power by the powerful university actors degenerates to manipulation or instrumental use of reason.

In situating the study in the university education sector in Malawi, the thesis contributes to the currently limited research base on policy and university education in the country. It is hoped that the thesis contributes to a quest for more research in this area in Malawi. More so, in emphasising the role of democratic policy engagement in the university sector in Malawi, the thesis contributes to debates and efforts to revitalise higher education in subSaharan African context generally (see Assié-Lumumba, 2006; Association of African Universities, 2004; Bloom, et al., 2006; Bloom \& Rosovsky, 2007).

\subsection{Limitations of the study}

This thesis follows the transformative nature of Critical Theory and, as such, analysis is biased toward the researcher's self-reflexivity in effecting social change. Further, since the research generally falls within qualitative research, results reflect global policy debates assessed, policy documents read and the four universities visited and, therefore, cannot be generalised. 


\subsection{Conclusion}

Chapter 1 has introduced Critical Theory and the nature of this thesis. The chapter has presented two parameters of Critical Theory useful for emancipation in this thesis: the ideas of dialectical reasoning and communicative rationality. It has been argued that these two ideas are central in exploring the nature of anti-democratic practices within the university sector in Malawi. Four major arguments that shall be reflected throughout this thesis have been presented in the chapter. Further, presented in the chapter; are the research problem, research objective and questions, the significance of the study and the study limitation.

\subsection{Chapter outline}

Chapter 2 highlights the issues of regionalism and neopatrimonialism in Malawian society and argues that these aspects give a context to antidemocratic practices in policy-steerage in the management and governance of university education in Malawi as revealed through data (see chapters 8 and 9).

Chapter 3 details the theoretical framework and shows why it is useful in exploring the nature of anti-democratic practices within policy-steerage, management and governance of university education in Malawi. The chapter starts by discussing competing paradigms or metatheories of positivism, interpretive inquiry and Critical Theory and shows that the latter is more suited for this thesis. The chapter proposes two useful ideas for emancipation based on Critical Theory to be used in the analysis of this thesis: dialectical reasoning as developed by the early generation Critical Theorists such as Horkheimer, Adorno and Marcuse and communicative rationality as developed by the second generation Critical Theorist, Habermas. 
Chapter 4 briefly describes the university sector and explains the major challenges faced by this sector in Malawi mentioning: problems of access, quality, management and governance and financing of the sector. While discussing challenges and efforts to revitalise the sector, where necessary, the chapter hints that the way some of the challenges are being tackled reflects neopatrimonial attitudes of the big-man syndrome and patron-client mechanisms permeating policy-steerage and governance of the sector to be discussed fully in chapters 8 and 9. The chapter argues that understanding challenges within the university sector by employing positivist logic only impedes an understanding of immeasurable challenges such as those that can be uncovered through Critical Theory. It augments the general argument made throughout this thesis that although there are efforts to revitalise the university sector in Malawi, efforts to explore the nature of anti-democratic practices that hinge on power relations are not given primacy.

Chapter 5 explains the research methodology of the thesis. While situating Critical Theory in qualitative inquiry, the chapter explains the study population, data collection methods and analysis and ethical issues in this thesis. It is mentioned in this chapter that while chapters 8-11 present analyses based on respondents' views or data, chapters 6 and 7 are based on analyses of global policy debates and education policy documents. The chapter presents the argument that Critical Theory enabled the researcher to expose the nature of anti-democratic practices and their sources within the university sector in Malawi and to produce emancipatory knowledge necessary for social change.

Chapter 6 assesses the World Bank's university policy-steerage in Africa based on policy debates. The chapter presents the contention that the World Bank's university policy-steerage in Africa follows the global-neoliberalorthodoxy and instrumental rationality in which African countries have no choice to chart their own university policy agenda. The chapter shows that the World Bank's instrumental use of reason in steering university policy in Africa 
is perpetuated by the powerful less-powerful logic, which reflects lack of dialectical reasoning and communicative rationality and, is as such, antidemocratic.

Chapter 7 discusses global changes in university governance and their impact on university governance in Malawi. The chapter shows evidence that the university sector in Malawi is gradually embracing the new-managerialism mode of governance. The chapter presents the argument that the newmanagerialism impedes democratic governance because of its stress on a performative and monitoring culture that resembles business models. These business models in universities follow the knowledge economy demand in aligning university education to industry at the expense of critical pedagogies. The new-managerialism mode of governance is as such, viewed in this thesis as following instrumental use of reason and anti-democratic. This chapter adds to the thesis by helping to show that the global-neoliberal-orthodoxy and knowledge economy demands perpetuated by the World Bank gradually permeate university governance in Malawi and shall eventually render the system anti-democratic.

Chapter 8 discusses research findings on governance and administrative practices at university level in Malawi based on respondents' views. It shows that democratic governance and administrative practices are challenged by the rivalry relationship among stakeholders and that universities employ constrained collegial decision or policy-making processes. The chapter presents the argument that the neopatrimonial attitude of presidentialism or the big-man syndrome permeates the governance and administration of Malawian universities and that as a result leaders within universities generally lack dialectic leading and fail to engage communicatively with other stakeholders within the academy. 
Chapter 9 explores the nature of anti-democratic practices within university policy-steerage by the Malawi Government. The chapter presents the following arguments: first, that the role of the state president as chancellor of public universities in Malawi presents problems in policy-steerage as presidents tend to use neopatrimonial aspects of presidentialism and patron-client relationships in their policy-steerage. Second, that consequently, university policy-steerage by the Malawi Government is interventionist and follows narrow political aspirations. Third, that university policy-steerage by the Malawi Government is woven within instrumental reasoning and lastly, that instrumental reasoning and neopatrimonial attitudes have eventually stifled academic freedom in Malawian universities. Consistent with Critical Theory as used in this thesis, the chapter proposes that the neopatrimonial attitudes need to be challenged and contained to allow for democratic university policysteerage in Malawi.

Chapter 10 discusses research findings on international influence on university policy-steerage in Malawi based on respondents' views. The chapter shows that the World Bank has much influence on university policy-steerage in Malawi because of its economic clout. The chapter reveals that in most cases, Malawi as a country has no choice or power to reject prescriptions from the powerful World Bank. Further, the chapter explains that the World Bank works through the Malawi Government with little room for professionals such as those involved in the university to contribute to university policyformulation which perpetuates a lack of critical engagement in policy-making. The chapter contends that the World Bank has used the Poverty Reduction Strategy Paper rationale to legitimise its power in Malawi. Like in chapter 6, this chapter presents the argument that the World Bank's university policysteerage in Malawi is conceived within the realms of instrumental rationality aimed at social control within the global-neoliberal logic and is antidemocratic. The chapter is useful as it explains respondents' personal views about the World Bank's policy-steerage and thus, adds understanding to antidemocratic practices revealed through policy debates discussed in chapter 6 . 
Chapter 11 presents respondents' views on improving the management and governance of the university sector in Malawi. Changes have been suggested at university, national and government policy-steerage levels. While respondents' views do not necessarily adhere to Critical Theory, they provide some basis for the emancipatory theory of university management and governance based on Critical Theory advanced in this thesis in chapter 12 .

Chapter 12 concludes the thesis by developing a theory of university management and governance for Malawian universities based on Critical Theory as a way of achieving emancipation. The proposed emancipatory theory employs dialectical reasoning and communicative rationality. It is argued that dialectical reasoning and communicative rationality are helpful in achieving a reflexive leadership, rationalising (in a Habermasian sense) neopatrimonial attitudes that permeate the university policy-steerage, management and governance and in curbing instrumental reasoning in policysteerage generally. Lastly, the chapter presents issues for further research. 


\section{CHAPTER 2}

\section{Regionalist politics and neopatrimonialism in Malawi}

\subsection{Introduction}

This chapter discusses regionalist politics and neopatrimonialism in Malawi in order to aid understanding of how they contribute to the nature of antidemocratic practices within university policy-steerage, management and governance. Before discussing regionalist trends and neopatrimonialism, a brief description of Malawi as a country follows.

Malawi is a landlocked country in Southern Africa that borders Tanzania to the northeast, Zambia to the northwest and Mozambique to the southeast and southwest (see Figure 1). Covering an area of 118, 484 square kilometres of which $20 \%$ is water, in 2008 it had a population of slightly more than 13 million inhabitants (Malawi Government, 2008). The Southern region had the highest population of 5, 876, 784 (45\%) in 2008 seconded by the Central region at 5, 491, $034(42 \%)$ and the Northern region was the least populated at 1, 698, 502 (13\%) (Malawi Government, 2008). The social situation in Malawi is highly stratified with about $80 \%$ of the poor population living in rural areas (Gilman, 2001). Malawi was under British protectorate since 1891 and part of the Federation of Rhodesia and Nyasaland from 1953 to 1964 (Vail \& White, 1989). The country became independent in 1964 under the dictatorship of Dr. Hastings Kamuzu Banda and the Malawi Congress Party which lasted for three decades. Currently, ideally under multi-party democracy, the country has conducted four elections in 1994, 1999, 2004 and 2009. Figure 1 shows the three regions of Malawi and its bordering countries. The discussion starts with regionalist politics in Malawi. 


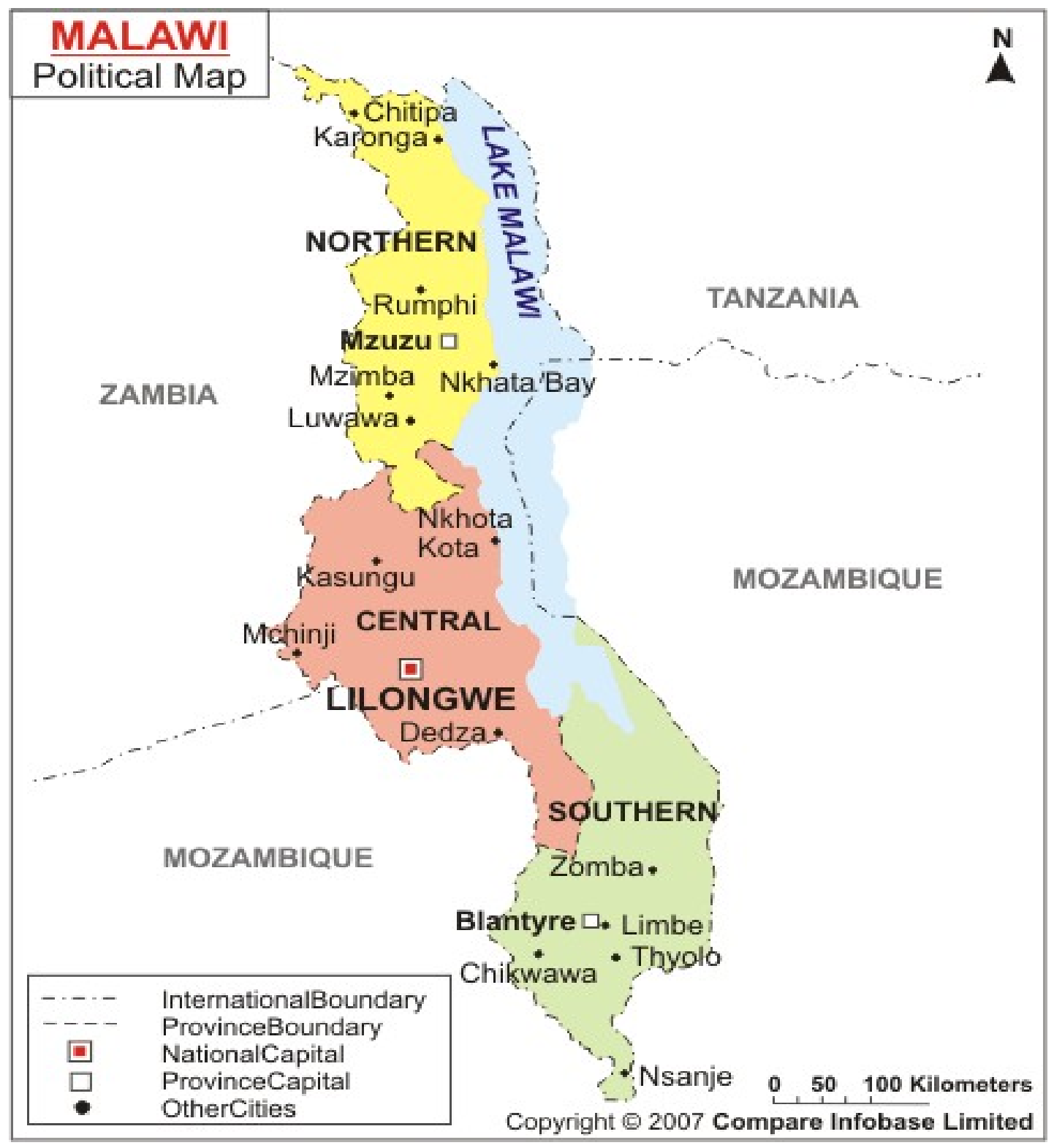

Figure 1: Political Map of Malawi showing regions: Northern, Central and Southern

\subsection{Politics and the crystallisation of regionalist practices in Malawi}

This discussion shall show how president Banda used his power that reflects the big-man syndrome, to be discussed later, negatively to crystallise regionalist trends in Malawi. As shown in Figure 1, Malawi is generally divided into three regions: Northern, Central and Southern which were organised by 
the colonial administration in 1921 (Vail \& White, 1989). In Malawi, these three regions have varied and distinct tribes that form their regional organisations. After independence, these divisions were maintained or crystallised and used as bases for the Malawi Government's administration (Posner, 1995). The three regions have historically, shown different experiences economically, socially and intellectually (Vail \& White, 1989). Understanding these different experiences is helpful in exploring the nature of anti-democratic practices within the university sector in Malawi as they help explain power relations among people from different regions. It shall be shown that the crystallised divisions and differences provide background to some anti-democratic trends in policy-steerage, management and governance of the university sector in Malawi.

The Northern region is the least developed (Williams, 1978) and as noted, the least populated of the three, regions (Malawi Government, 2008). Historically, however, the Northern region has been advantaged by a quest for education instilled by the Presbyterian missionaries (Posner, 1995; Vail \& White, 1989). The Central and Southern regions remain more developed and have historically adhered to tobacco farming and business oriented activities respectively other than schooling (Posner, 1995). These differences combined with crystallised regional identities and population dynamics among regions pose great challenge to Malawi's socio-political life including university education policy in which the majority have an upper hand in having their voices heard in policy formulation. In neopatrimonial terms, as shall be explained later, it becomes easier to make policies that adhere to patron-client mechanisms at the expense of those adhering to rationality required to protect minority groups (see Booth, et al., 2006; Engel \& Erdmann, 2007; Gilman, 2001, 2004).

One of the issues that helped crystallise regionalist trends was the privileging of the Chewa language and culture at the expense of other languages and cultures in Malawi by Banda (a Chewa by tribe) (see Kamwendo, 1994; 
Kayambazinthu, 1998; Matiki, 2001; Posner, 1995). While privileging the Chewa language was meant to achieve national linguistic homogeneity (Kaspin, 1995; Matiki, 2001), it largely led to resentment (Short, 1974) and the development of two major language blocks based on use of two languages: the Chewa speaking Southern and Central regions and the Tumbuka speaking Northern region.

Despite many ethnic groups in Malawi such as Chewa, Nyanja, Tumbuka, Yao, Lomwe, Sena, Tonga, Ngoni, and Ngonde (Kaspin, 1995; Kayambazinthu, 1998; Vail \& White, 1989), as early as in 1964 Banda decided to privilege the language and culture of the Chewa making the country to solely reflect the Chewa culture (Matiki, 2001; Posner, 1995). Banda claimed that many Malawians despite coming from other regions were in fact Chewa only they did not realise it (Matiki, 2001; Vail \& White, 1989). He, eventually, used deliberate and militant ways in privileging the Chewa language and culture (Kayambazinthu, 1998). For example, the Malawi Congress Party Convention of 1968, decided that Chichewa become a national language without any proper research to warrant the policy (Matiki, 2001). Following on this, the Malawi Parliament decreed that Chichewa and English were the only national languages in Malawi (Kayambazinthu, 1998; Matiki, 2001). With the 1968 declaration, Banda banned all other languages from press and radio (Kayambazinthu, 1998; Matiki, 2001; Vail \& White, 1989). This was problematic for the northerners as their Chitumbuka language had by 1947 become one of the two official languages (see Kayambazinthu, 1998; Posner, 1995; Vail \& White, 1989). However, although the ban on Tumbuka and other minority languages was formally instituted, the Tumbuka language had already developed as a lingua franca ${ }^{2}$ of the Northern region such that the imposed ban could not actually kill the language (see Kamwendo, 2004; Kayambazinthu, 1998; Matiki, 2001; Vail \& White, 1989). Instead, the ban only

\footnotetext{
${ }^{2}$ Lingua franca means a common language among speakers of other languages
} 
facilitated the development of Chichewa as a lingua franca of the Southern region.

Banda established the Chichewa Board in 1972 with a mandate to expand the usage of Chichewa as a national language (Kayambazinthu, 1998) and further directed the establishment of the Chichewa Department at the University of Malawi as a way of developing and expanding the language (Kayambazinthu, 1998; Matiki, 2001).

The government established the National Examination Board which replaced the Cambridge Examination Board to deal with the country's examination and award of certificates for primary and secondary school level students (see Kayambazinthu, 1998). Two contested issues by the Banda regime followed this establishment: first, it was decided that all children who failed Chichewa in schools were required to resit examinations (Short, 1974), and second, that students from the Northern and Southern regions had generally to obtain higher grades in their final primary school examinations than those of the Central region to qualify for secondary education (Vail \& White, 1989). These measures, among other reasons, were put in place to force other ethnic groups to learn Chichewa (Kayambazinthu, 1998).

All in all, the argument is that following the ban on minority languages, with time, two language blocks that were already evident during the colonial time were perpetuated: the Chitumbuka speaking minority region of the north and the Chichewa speaking majority of the central and south (see Kaspin, 1995). The contention is that banning of minority languages facilitated negative attitudes among the majority Malawians who started to view minority languages and their speakers as inferior to Chichewa and its speakers. It is argued that eventually with the two language groups, Banda, used language to perpetuate a mentality among Malawians to view the minority northerners as "other" (Canales, 2000) or different from the majority Malawians who shared 
Chichewa as a language of communication. Given the patron-client mechanisms of neopatrimonialism to be discussed later, the two language groups provide challenges for policy-steerage generally.

Regionalism was also perpetuated by the way Banda treated minority groups in Malawi. Since independence, minority groups especially northerners were victims of the Banda regime (Kaspin, 1995; Posner, 1995). Northerners were at independence highly represented in the civil service and the university (Posner, 1995; Williams, 1978) hence throughout the 1970s, deliberate steps were taken to reduce the representation of non-Chewas and northerners in particular from these institutions (Posner, 1995). Banda's real reasons for purging northerners from higher education institutions can only be speculative. It could have been a way of consolidating power by weakening a region that was promising education wise or a reaction to the 1964 cabinet crisis in which some prominent figures from the north were among those who differed with Banda's style of rule (see Kayuni \& Tambulasi, 2010; Posner, 1995).

Almost at all levels, school achievement for the northerners was not viewed positively by the Banda regime generally (Posner, 1995). For example, In 1988, unproved allegations stated that a number of northern region employees at the Malawi National Examination tampered with results of the Malawi School Certificate of Education to achieve high pass rates for students from the north (Posner, 1995). In the following year, Banda accused teachers of northern region origin of deliberately interfering with the education of children from the Chewa speaking regions so as to reserve jobs for northerners (Posner, 1995). At the time, Banda ordered all teachers from the north to go and teach in their home region (Posner, 1995). It is argued that the sending of all teachers from the north to teach in their places of origin served as an example of regionalist practices which reified the north and its people to be viewed as "other"(see Canales, 2000). 
Given the issues highlighted, it was not surprising that in 1989 the Malawi Government introduced a quota system for university selection based on districts of origin and district population which reduced the number of students from the north, to enter university (Chirwa, 1994; Posner, 1995). Although this policy was rescinded in 1993 when some concerned students challenged it in the high court, in 2009, Malawi readopted the formal quota system of university selection that follows the same logic of 1988. In the name of equitable access to higher education, the formal quota also works on selecting students to universities based on their districts of origin and employs population dynamics. The policy has received criticism from the public especially human rights as well church groups, and some political parties who contend that the policy required greater consultation.

In general terms, it is argued that the wrath by the Banda political machinery toward the northerners made it possible for Malawians from other regions to begin to view northerners as "other" and perhaps "less" Malawian (Canales, 2000). Hence, the behaviour of the Banda regime toward minority groups especially the northerners is helpful for an understanding of some of the current anti-democratic trends within the university sector in Malawi. The discussion has shown that the struggle to reduce the participation of northerners from university education has a long history and reflects regionalist trends initiated by the colonial administration and crystallised by Banda and the Malawi Congress Party. Apart from regionalist practices, neopatrimonialism in Malawi's socio-political life also provides context to antidemocratic practices in the university sector as shall be discussed next.

\subsection{Conceptualising neopatrimonialism}

The discussion on neopatrimonialism in the socio-political life of Malawi shall conceptualise the notion neopatrimonialism and give examples of 
neopatrimonial practices in Malawi's socio-political life. It is argued in this discussion that neopatrimonialism in Malawi is normative and that it is this normativity or the taken-for-granted (using Habermasian ideas) that facilitates neopatrimonialism to permeate policy-steerage, management and governance of universities in Malawi (see Carr \& Kemmis, 1986; Habermas, 1984, 1987).

The word neopatrimonialism is a combination of the prefix neo (new) and the word patrimonialism. Political scientists make use of Max Weber's (18641920) term, patrimonial state, to describe pre-industrial states in which wealth belongs to the patrimony of the ruler other than to the public (Booth, et al., 2006; Engel \& Erdmann, 2007). It follows that under patrimonialism, all power represents personal relations and there is no difference between the private and the public (Booth, et al., 2006; Engel \& Erdmann, 2007).

In contrast, the word neopatrimonialism reflects a new way of defining states which is a combination of aspects of the patrimony and the modern logic of rule, as such, it describes hybrid states. Von Soest (2007) contends that although not absolutely related to Africa, the term has been used by political scientists to explain Africa's political, democratic and economic challenges. An explanation of democratic deficiencies within the neopatrimonial logic is helpful in understanding how neopatrimonialism renders the management of the university sector in Malawi anti-democratic.

While under neopatrimonialism a formal distinction between the private and the public exists, power taps on both of them (Booth, et al., 2006). The idea of power operating on both the private and the public is well captured by Engel and Erdman who state that in neopatrimonialism:

...Formal structures and rules do exist, although in practice the separation of the private and the public sphere is not always observed. In other words two role systems or logics exist next to each other, the patrimonial of the personal relations, and the legal-rational of the 
bureaucracy. The spheres are not isolated from each other. Quite contrary they permeate each other (Engel \& Erdmann, 2007, p. 105).

The hybrid states of neopatrimonialism exhibit three major characteristics: presidentialism (the big-man syndrome), clientelism and patronage (award of personal favours to individuals and groups respectively) and use of political resources for political legitimation (misuse of resources) (see Bratton, Gyimah-Boadi, \& Mattes, 2004; Bratton \& van de Walle, 1997; Cammack, 2007a, 2007b; Cammack, Golooba-Mutebi, Kanyongolo, \& O'Neill, 2007; von Soest, 2007).

Presidentialism refers to the dominance of one individual who normally uses patron-client powers to achieve absolute rule (see Booth, et al., 2006). In politics, under this system, the president is the big-man who normally decorates himself with titles that depict power such as father and founder of the nation, and life-president (see Chirambo, 2001, 2004, 2007, 2009). With such dominant leaders the state becomes a single man show. In neopatrimonial states, the powers of the dominant figure impinge on the activities of other political and state institutions (Booth, et al., 2006). Using data the thesis shall show that similar behaviours are evident within university policy-steerage, management and governance in Malawi.

Engel and Erdmann contend that "clientelism means the exchange or brokerage of specific services and resources for political support, often in the form of votes... involves the relationship between unequals, in which the major benefits accrue to the patron" (2007, pp. 106-107). Thus, clientelism facilitates personal favours such as job offers or appointments by the big-man to individuals in order to for the big-man to sustain rule or power (see Booth, et al., 2006; Engel \& Erdmann, 2007; Kurer, 2007). 
Patronage is a form of clientelism applied to groups of people such as providing development finance within the logic of patrimony (Engel \& Erdmann, 2007). Engel and Erdman contend as follows:

Clientelism implies a dyadic and asymmetric relationship between patron and client, while patronage refers to the relationship between an individual and a bigger group. The difference between clientelism and patronage is essentially a distinction between the recipients...The distribution of these benefits follows personal or particularistic interests by violating universalistic rules...The mechanism is usually based on the following perception and rationality: if one of us is involved, it will be more beneficial for us than if another who is not of our kin and who may not have our interest at heart (Engel \& Erdmann, 2007, p. 107).

In this thesis, as shall be shown later, it is argued that apart from other antidemocratic practices, the Malawi Government policy-steerage adheres to the patron-client logic as explained above.

The use of political resources for legitimation describes how big-men access special funds at their discretion. In politics, thus, in neopatrimonial states, it is not surprising that state resources, government positions, provision of services as well as policy-making are effectively in the hands of the big-man (Booth, et al., 2006; Engel \& Erdmann, 2007; von Soest, 2007). As such, the state lacks the ability to govern democratically as it is caught up to serving particular interests and groups (Booth, et al., 2006). More so, in such states, corruption is usually common and in most cases choices of leaders depend on how much voters can get from their leaders within the patron-client logic (Booth, et al., 2006). In neopatrimonial logic, alien origins disadvantage the leaders as they are not part of the patron-client web (Booth, et al., 2006). Given the crystallisation of regional divisions and differences in Malawi, it is normal to view people from other regions as foreigners and remote to the regional organisation or system: one is either from the minority north or the majority central and south (see Kaspin, 1995). 
The patron-client web in neopatrimonial states make parliaments as well as the civil society weak (see Cammack, 2007a, 2007b; Cammack, et al., 2007; Gilman, 2001, 2004). As such, neopatrimonial states normally show a lack of policy autonomy and the ability to formulate democratic policies as interests are caught up within the patron-client network (Booth, et al., 2006; Cammack, 2007a). While thus far, the discussion has concentrated on conceptualising the notion neopatrimonialism, to understand better how neopatrimonialism provides context to this thesis, the discussion now turns to neopatrimonialism in Malawi's socio-political life.

\subsubsection{Neopatrimonialism in the socio-political life of Malawi}

Neopatrimonialism in the socio-political life of Malawi has deep roots. All aspects of neopatrimonialism: presidentialism or the big-man syndrome, clientelism and patronage and use of political resources for political legitimation are reflected in Malawi's socio-political life. In general, neopatrimonialism in Malawi seems to be posited normatively due to differences in power relations such as between the rich and the poor (Booth, et al., 2006). For example, in terms of presidentialism, Gilman (2001) posits that since the social situation in Malawi is highly stratified the poor population is less powerful and is prone to be susceptible to blind loyalty to the rich and powerful. This results into reality "in which the ruling elite controls and owns most of the country's economic and political resources, while the majority of the population is hoping to attain any little bit through goodwill and generosity of these same people" (Gilman, 2001, p. 46).

Neopatrimonialism, in its presidential form or big-man syndrome, is also seen as an extension of colonial logic in which there is the powerful (the colonial masters or the present government) and the less powerful (the local people) (Booth, et al., 2006). The powerful less-powerful analogy however, translates deeply at every level of the socio-political life in Malawi in which, for example, 
the big-men who have power want to exert absolute control over the led or the less powerful (Booth, et al., 2006). In terms of the university sector, power relations among stakeholders such as university chancellors, managers, academics and students also reflect this neopatrimonial powerful lesspowerful analogy as revealed by data in chapters 8 and 9 .

In Malawi, this powerful less-powerful relationship demands an expectation that the big-men in power support their relations to get loyalty in reciprocity (Booth, et al., 2006). Such expectations have the potential to curtail democratic policy-steerage. The neopatrimonial attitudes that perpetuate the powerful less-powerful relationships need the less powerful to be dependent on the powerful individuals making concentrated use of power and dependency normative in Malawian society (Booth, et al., 2006). Anti-democratic practices are strongly reinforced by this normative stance founded within Malawi's socio-political life (Booth, et al., 2006). It is this normative stance, the takenfor-granted, that facilitates neopatrimonial attitudes to permeate the management and governance of university education in Malawi and which needs to be rationalised (in a Habermasian sense) in order to emancipate stakeholders within the university (see Habermas, 1984, 1987). The next discussion exemplifies neopatrimonial attitudes or the taken-for-granted that require to be challenged in Malawi's socio-political life. Exemplifying neopatrimonial attitudes adds more understanding on how these attitdues permeate the university sector in Malawi.

\subsubsection{Neopatrimonialism under one-party and multi-party periods}

This discussion demonstrates how neopatrimonialism is ingrained within Malawi's socio-political life and is a taken-for granted phenomenon. While there are many examples of neopatrimonialism at every level of society in Malawi, the discussion uses the behaviours of presidents. Neopatrimonialism in Malawi has early roots. It can be traced to the time Malawi was a British 
protectorate from 1891 and later as part of the Federation of Rhodesia and Nyasaland from 1953 which comprised Southern Rhodesia (Zimbabwe), Northern Rhodesia (Zambia) and Nyasaland (Malawi) (Booth, et al., 2006). The colonial masters were the powerful and the local Malawians, the less powerful. This, however, did not change when the country became independent in 1964 under the authoritarian rule of Banda and his Malawi Congress Party (Booth, et al., 2006). Banda's big-man syndrome culminated in the authoritarian rule that lasted for 30 years only to be challenged in 1994 when Malawi embraced multiparty democracy. Banda was invited to Malawi in 1958 from the United Kingdom to lead the Nyasaland African Congress, and, as soon as he became president, he imprisoned, exiled or killed his opponents (Chirambo, 2001; Posner, 1995). The Banda regime followed the following three major strategies: the centralisation of political and economic power in the hands of the big-man, Banda; the merciless treatment of political opponents and the total control of public life (Posner, 1995). Banda instituted "what was probably the most repressive, corrupt, predatory and violent political system in Africa through combination of bribery, intimidation, election malpractices and the suffocation of civil society" (Inhonvbere, 1997, p. 225).

To sustain presidentialism or the big-man syndrome, Banda used ideological leadership (Chirambo, 2004). This was manifested in the way he created a special idolised image of himself: He was the Father and Founder of the Malawi nation; he was the only person that Malawians wanted to rule the country, and, like Jesus Christ, he was chosen by God before he was born to save Malawi (Chirambo, 2004). He was thus called, His Excellency, Ngwazi Dr. H. Kamuzu Banda, the Life President of the Republic of Malawi. The name Ngwazi means conqueror or saviour (Chirambo, 2004). The other titles that complemented these included: Wamuyaya (one who reigns for ever), Nkhoswe No.1 (the protector of women) (Chirambo, 2001, 2007) and Mkango wa Malawi, (The Lion of Malawi) (depicting the absolute power of the big-man). The special image that Banda created about and for himself was reified through folk music and dance that people performed for their saviour 
(Chirambo, 2001, 2004, 2009; Gilman, 2001). Women were often used to compose songs of praise drawing on the rich heritage of oral tradition in Malawi (see Chirambo, 2001, 2004, 2007, 2009). Chirambo (2001) argues that the songs that women composed were more than just political propaganda as they vividly deified him. Chirambo (2001) gives an example of one song sung by the Women's League from Rumphi district that went:

"BaNgwazi wandababike

Chiuta wakawasola

Kuwa mulongozgi muno m'Malawi

Before Ngwazi was born

God chose him

To be the leader in Malawi" (p. 206)

In the same vein this big-man and saviour was the "biggest" in the whole of Africa as the members of Women's League from Ntcheu portrayed in one of their songs:

Kuno ku Malawi kuno

Ngakhale mu Africa

Kulibe wina puresidenti woposa Kamuzu

Mbumba zikunyadira

Ife tikunyadira, kulibe wina purezidenti woposa Kamuzu

Here in Malawi

Even in the whole of Africa

There is no president as powerful as Kamuzu

Women are happy

We are happy

There is no president as powerful as Kamuzu

Thus, normatively, Malawians believed or were meant to believe that Banda was really chosen by God hence no one would equate to him. 
Further, exhibiting neopatrimonial attitudes, Banda perpetuated relationships based on patronage with people (Booth, et al., 2006). For example, he built houses for key women in the Women's League which facilitated loyalty to him (Booth, et al., 2006). In terms of use of political resources for political legitimation, under Banda, private-sector resources and party resources were readily under his use (Booth, et al., 2006). For example, during the yearly crop inspection tours that he undertook, "private as well as government vehicles were commandeered to ferry the dancing women and the party members to attend rallies" (Booth, et al., 2006, p. 10).

Malawi moved from a one party system of government to a multiparty democracy in 1994. There were several reasons for this change: first, the $8^{\text {th }}$ March 1992, pastoral letter by the Catholic Bishops that challenged the dictatorial form of government; second, the economic problems due to Banda's patronage based rule; third, changes in the Southern Africa region that pointed toward multi-party democracy and fourth, the University of Malawi Students' protests against human rights abuses in Malawi generally (see Inhonvbere, 1997; Posner, 1995).

With the dawn of multiparty democracy, it was expected that most issues surrounding governance would change for the better. However, aspects of neopatrimonialism have carried over to democratic rule revealing how ingrained within the Malawi society they are. For example, both multi-party presidents: Bakili Muluzi (1994-2004) and Bingu wa Mutharika (2004-2014) have in their own ways sustained neopatrimonial tenets in their rule. Features of the big-man have been carried over by the two presidents (Booth, et al., 2006). Cammack quotes an informant's account of when Mutharika speaks:

No one should question. He has reached the point that the cabinet has to clap hands and sing. The same songs we sang for Kamuzu, we sing for him. This is a human being living in different era and this era is not good for him because it requires that you have to listen and compromise....when he makes a statement in cabinet, everyone has to 
agree. When you do not, you are seen as a barrier (Cammack, 2007a, p. 6).

The Centre for Human Rights and Rehabilitation (CHRR) accused Mutharika of flouting rules and procedures in policy-making, threatening people's rights and implementing policies in a contradictory and inconsistent way (Cammack, 2007a). Both Muluzi and Mutharika as did Banda, used special names to invoke populism and to assert the big-man syndrome. Muluzi, referred to himself as kumutunda kuno meaning (getting to me is uphill) and woasachepa kaba (to have broad chest) (Booth, et al., 2006). Mutharika adopted the title used by Banda, Ngwazi. He saw himself as the conqueror just like the big-man, Banda was. Cammack (2007a) contends that Mutharika behaves like Banda trying to use dictatorial powers in a democratic era. Both Muluzi and Mutharika, like Banda before them, have used women to dance and sing praises for them (see Booth, et al., 2006; Chirambo, 2001; Gilman, 2001, 2004). The same songs that women sang for Banda were sung for Muluzi and Mutharika (Booth, et al., 2006).

Like Banda, both Muluzi and Mutharika have used patronage to sustain power (Booth, et al., 2006). While Banda built houses for some members of the Women's League, Muluzi often gave loans to women and others within the patron-client logic (Booth, et al., 2006). Further Muluzi gave senior positions to people who assisted him to get to power (Booth, et al., 2006).

Both Muluzi and Mutharika failed to distinguish between private-sector resources and party resources like the big-man, Banda (Booth, et al., 2006). While Banda used private as well government vehicles to ferry people to his rallies, Muluzi did the same during his development tours (see Booth, et al., 2006). All presidents have tried to sustain loyalty by threatening voters with withholding development finance for their areas if voters do not give them support (Booth, et al., 2006). Mutharika used public resources as his own as 
exemplified by paying school fees for his children and grandchildren from a public fund only to justify the act because Muluzi, before him, also did it (Cammack, 2007a).

The continuation of neopatrimonial thinking combined with regionalist trends has complicated the socio-political life in Malawi including university policysteerage. Regionalist trends and neopatrimonialism in Malawi are also reflected in the presidential elections voting pattern as shown in the next discussion.

\subsection{The primacy of regionalism and neopatrimonialism in Malawi}

This discussion uses Malawi's presidential election results to show how the combined forces of regionalism and neopatrimonialism have affected Malawi's socio-political life. It is argued that with the crystallisation of regionalist trends in Malawi, people tend to support each other within the neopatrimonial logic of the patron-client relationship and that this is reflected within the presidential voting pattern (see tables 1-4). Regionalist and neopatrimonial practices have been very vivid in Malawi's election results since 1994. Posner commented:

While the emergence of regional identities may be traced to the preindependence period, the primacy of regionalism in political life today is as much an outcome of the character of post independence rule and the nature of the campaign leading up to the May 1994 elections which at once reflected and deepened the country's tripartite division as it is a legacy of colonialism. Whatever its origins, Malawi's regional polarization poses a serious obstacle to the consolidation of democracy (Posner, 1995, p. 133).

Tables I-4 show presidential election years, presidential candidates, presidential candidates' regions of origin and the percentage number of votes they won in the different regions. Although table 4 shows that the 2009 election results are an exception with one candidate getting close to landslide 
victory, the 1994, 1999 and 2004 results show a voting pattern that reflects regionalist as well as neopatrimonial logic. In 1994 the major parties in contention were the Malawi Congress Party (predominantly from the Central region), the Alliance for Democracy (predominantly from the Northern region) and the United Democratic Front (predominantly from the Southern region) (see Table 1).

Table 1: Presidential election results in 1994 (major candidates only)

\begin{tabular}{|l|l|l|l|l|}
\hline \multicolumn{1}{|c|}{$\begin{array}{c}\text { Presidential } \\
\text { candidate }\end{array}$} & $\begin{array}{c}\text { Region of origin } \\
\text { of the candidate }\end{array}$ & $\begin{array}{c}\text { Northern } \\
\text { region votes } \\
\text { (\%) }\end{array}$ & $\begin{array}{c}\text { Central } \\
\text { region votes } \\
\text { (\%) }\end{array}$ & $\begin{array}{c}\text { Southern region } \\
\text { votes (\%) }\end{array}$ \\
\hline $\begin{array}{l}\text { Chakufwa Chihana } \\
\text { (Alliance For } \\
\text { Democracy: } \\
\text { AFORD) }\end{array}$ & north & $87.8 \%$ & $7.5 \%$ & $5.2 \%$ \\
\hline $\begin{array}{l}\text { Bakili Muluzi } \\
\text { (United } \\
\text { Democratic Front: } \\
\text { UDF) }\end{array}$ & south & $4.5 \%$ & $27.5 \%$ & $78.0 \%$ \\
\hline $\begin{array}{l}\text { Kamuzu Banda } \\
\text { (Malawi Congress } \\
\text { Party: MCP) }\end{array}$ & central & $7.3 \%$ & $64.3 \%$ & $16.1 \%$ \\
\hline
\end{tabular}

Source: African Elections Database

Table 1 shows that all the three presidential candidates had overwhelming support from their regions of origin. In 1999, there was an alliance between Malawi Congress Party and Alliance for Democracy and the results showed a continuation of the 2004 voting pattern (see Table 2) 
Table 2: Presidential election results in 1999 (major candidates only)

\begin{tabular}{|l|l|l|c|c|}
\hline \multicolumn{1}{|c|}{$\begin{array}{c}\text { Presidential } \\
\text { candidate }\end{array}$} & $\begin{array}{c}\text { Region of origin of } \\
\text { the candidate }\end{array}$ & $\begin{array}{c}\text { Northern } \\
\text { region } \\
\text { votes (\%) }\end{array}$ & $\begin{array}{c}\text { Central } \\
\text { region votes } \\
\text { (\%) }\end{array}$ & $\begin{array}{c}\text { Southern region } \\
\text { votes (\%) }\end{array}$ \\
\hline $\begin{array}{l}\text { Bakili Muluzi } \\
\text { (United } \\
\text { Democratic } \\
\text { Front) }\end{array}$ & south & $9.4 \%$ & $35.2 \%$ & $78.3 \%$ \\
\hline $\begin{array}{l}\text { Gwanda } \\
\text { Chakuamba } \\
\text { (Malawi } \\
\text { Congress Party } \\
\text { and Alliance for } \\
\text { Democracy) } \\
\text { Alliance }\end{array}$ & $\begin{array}{l}\text { south (but in coalition } \\
\text { with northern party) }\end{array}$ & $88.6 \%$ & $62.4 \%$ & $18.5 \%$ \\
\hline
\end{tabular}

Source: African Elections Database

The same voting pattern and logic was repeated in 2004 as shown in Table 3 below.

Table 3: Presidential election results in 2004 (major candidates only)

\begin{tabular}{|l|l|l|c|c|}
\hline \multicolumn{1}{|c|}{$\begin{array}{c}\text { Presidential } \\
\text { candidate }\end{array}$} & $\begin{array}{c}\text { Region of origin of } \\
\text { the candidate }\end{array}$ & $\begin{array}{c}\text { Northern } \\
\text { region } \\
\text { votes (\%) }\end{array}$ & $\begin{array}{c}\text { Central } \\
\text { region votes } \\
\text { (\%) }\end{array}$ & $\begin{array}{c}\text { Southern region } \\
\text { votes (\%) }\end{array}$ \\
\hline $\begin{array}{l}\text { Gwanda } \\
\text { Chakuamba } \\
\text { (Republican } \\
\text { Party) }\end{array}$ & south & $73.3 \%$ & $7.7 \%$ & $24.5 \%$ \\
\hline $\begin{array}{l}\text { Bingu Wa } \\
\text { Mutharika } \\
\text { (United } \\
\text { Democratic } \\
\text { Front) }\end{array}$ & south & $16.2 \%$ & $23 \%$ & $53.1 \%$ \\
\hline $\begin{array}{l}\text { John Tembo } \\
\text { (Malawi } \\
\text { Congress Party) }\end{array}$ & central & $3.3 \%$ & $62.2 \%$ & \\
\hline
\end{tabular}

Source: www.judicary.mw/election/ele2004national_distr.htm 
Although Table 4 shows a huge change in voting patterns with one candidate gaining overwhelming majority, this could have been because of the events that followed during the 2004-2009 rule that are outside the focus of this thesis. Table 4 shows the 2009 presidential results.

Table 4: Presidential election results in 2009 (major candidates only)

\begin{tabular}{|l|l|l|l|c|}
\hline \multicolumn{1}{|c|}{$\begin{array}{c}\text { Presidential } \\
\text { candidate }\end{array}$} & $\begin{array}{c}\text { Region of origin of } \\
\text { the candidate }\end{array}$ & $\begin{array}{c}\text { Northern } \\
\text { region } \\
\text { votes (\%) }\end{array}$ & $\begin{array}{c}\text { Central } \\
\text { region votes } \\
\text { (\%) }\end{array}$ & $\begin{array}{c}\text { Southern } \\
\text { region } \\
\text { votes } \\
\text { (\%) }\end{array}$ \\
\hline $\begin{array}{l}\text { Bingu wa } \\
\text { Mutharika (DPP) }\end{array}$ & south & $94.84 \%$ & $49.76 \%$ & $68.03 \%$ \\
\hline $\begin{array}{l}\text { John Tembo } \\
\text { Congrawi } \\
\text { and United } \\
\text { Democratic } \\
\text { Front alliance) }\end{array}$ & central & $3.0 \%$ & $46.39 \%$ & $28 \%$ \\
\hline $\begin{array}{l}\text { Dindi Gowa } \\
\text { Nyasulu } \\
\text { (Alliance for } \\
\text { Democracy) }\end{array}$ & north & $0.57 \%$ & $0.38 \%$ & $0.49 \%$ \\
\hline
\end{tabular}

Source: Malawi Electoral Support Network (MESN) 2009

In general, the voting pattern suggests regionalist trends and neopatrimonial attitudes took primacy within presidential elections in Malawi. This trend provides crucial context for an analysis of the nature of anti-democratic practices within the university sector in Malawi.

\subsection{Conclusion}

Chapter 2 has discussed regionalist politics and neopatrimonialism in Malawi. The contention is that the combined forces of regionalism and neopatrimonialism provide vital context for understanding the anti- 
democratic nature of university policy-steerage, management and governance in Malawi. Regionalism and neopatrimonialism provide potential for actors to employ instrumental use of reason or social control in the running of the university sector in Malawi. 


\section{CHAPTER 3}

\section{Critical Theory as theoretical framework}

\subsection{Introduction}

As noted, this thesis draws on Critical Theory as a theoretical framework. Critical Theorists have since Horkheimer been interested in the idea of critique (that which informs emancipation) within Critical Theory (see Habermas, 1984, 1987; Horkheimer, 1978; How, 2003; Marcuse, 1941, 1978). Although critique for them is embedded in reason, it is how reason can be used for emancipation that is their preoccupation. This section attempts to bring forward what informed critique for the first generation Critical Theorists such as Horkheimer, Marcuse and Adorno and what informs critique for the second generation represented by Habermas. While critique has different foundations for both groups, in this thesis the two ideas are viewed as complementary in exposing and suggesting social changes to anti-democratic practices within Malawian universities. This is not to turn a blind eye to the development of the theory, but to show the versatility of Critical Theory in that it is flexible and can be applied differently according to the nature of the social problems requiring critique. Further, while these philosophers were also preoccupied with normative foundations of their philosophies, the task at hand in this thesis is not about establishing normative foundations, rather to establish the application of Critical Theory in exploring the nature of anti-democratic practices requiring emancipation or social change within universities in Malawi.

Like Habermas the study does not attach critique to the Marxian notion of historical materialism (Habermas, 1984, 1987). However, unlike Habermas, the study retains the idea of the dialectical and argues that it is useful in democratising institutions such as universities in Malawi. Thus, as alluded to 
earlier, two aspects of Critical Theory inform analysis in this thesis: the idea of the dialectical (the idea of an ongoing reflexivity in our actions) (see Adorno, 1982; Carr, 2000; Horkheimer, 1978; How, 2003; Marcuse, 1941, 1978) and Habermas's communicative rationality in which democracy and social justice demand the use of the force of reason as opposed to the force of coercion (Habermas, 1984, 1987, 1998). Both dialectic reasoning and communicative rationality in this thesis are seen to embody democratic values that enforce reflexivity and mutual respect of actors in achieving democratic practices within a university education system. The chapter begins by defining a theoretical framework or paradigm and describing competing paradigms before presenting the argument that Critical Theory is the most suitable approach to this study as it allows researchers to go beyond mere interpretation of reality to proposing social change (Carr \& Kemmis, 1986; Habermas, 1984, 1987).

\subsection{Definition of a paradigm or theoretical framework}

The idea of establishing a definition of a paradigm in this research is to show how paradigms in general influence research (Bailey, 2007). This shall be helpful in exploring the nature of anti-democratic practices within policysteerage, management and governance of university education in Malawi at international, university and government levels and in suggesting ways of emancipation or social change.

A paradigm is defined as "a general organising framework for theory and research that includes basic assumptions, key issues, models of quality research and methods of seeking answers" (Neuman, 2006, p. 81). Examples of paradigms are positivist inquiry, interpretivist inquiry and Critical Theory (Bailey, 2007; Neuman, 2006; Waghid, 2003; Weaver \& Olson, 2006; Willis, et al., 2007). Paradigms consist of ontological (questions about the nature of reality), epistemological (the relationship between the knower and the known 
or the way people know), axiological (concerned with the role of values and ethics in research) and methodological assumptions (procedures for understanding the world) (Bailey, 2007). A paradigm is different from research methods in that methods are techniques used to collect data such as employing questionnaires, interviews and observation (Bailey, 2007; Willis, et al., 2007). Paradigms, thus, influence the whole research project as Bailey contends:

Researchers' paradigmatic beliefs influence the purposes of their research, how they will conduct the research, how they will assess the role of values and ethics in their work, how they will formulate relationships to respondents in the setting, how their work will be presented, and many other aspects of the research process (Bailey, 2007, p. 50).

As such, differences within competing paradigms get reflected in their ontological, epistemological, axiological and methodological assumptions (Bailey, 2007; Willis, et al., 2007). The following discussion turns to positivist and interpretive inquiries and shows how as frameworks they are limited in assisting to answer the research questions for this thesis. Understanding these differences is important in order to establish an understanding of how the use of Critical Theory goes beyond mere interpretation of reality to effecting social change (see Carr \& Kemmis, 1986).

\subsubsection{The Positivist Inquiry}

Positivist inquiry is generally viewed as a reaction to knowledge that was premised on Christian religion (Willis, et al., 2007). Founded in $19^{\text {th }}$ century by Augustine Comte, positivism emphasises discovering causal laws in research (Neuman, 2006; Waghid, 2003; Willis, et al., 2007). The paradigm was further elaborated by philosophers of the Vienna Circle in the 1920s also known as logical empiricist, logical neopositivists and neopositivists that included Schlick, Carnap, Neurath and Hempel (Neuman, 2006). These philosophers' 
major concern was to develop a scientific method for establishing valid knowledge (Neuman, 2006; Willis, et al., 2007). Willis argues as follows:

Logical positivists were materialists and realists in that they believed that only the physical or real world existed, they were empiricists in that they judged the truth of statements by comparing them to what actually happened to the real world and they were positivists in that they believed the scientific method was the sole source of valid knowledge (Willis, et al., 2007, p. 42).

The positivist ontological position is that reality is, out there, and can be known through rigorous investigation; hence epistemologically they view what can be learned about the social world as existing independently of the researcher (Willis, et al., 2007). With this ontological view, it is not surprising that their axiological position is that research should be value free and consequently, methodologically, research raises questions of reliability, validity and generalisation (Bailey, 2007; Waghid, 2003). Thus, since for this world view, knowledge is real and out there to be discovered and is value free, explanation becomes nomothetic where for example A is caused by B because A and B are specific instances of a causal law (Carr \& Kemmis, 1986; Neuman, 2006; Waghid, 2003). Applied to research, positivism requires establishing hypotheses, generalisation of results and replication of research to determine valid knowledge (Waghid, 2003).

Positivism is not an appropriate approach for an exploration of the nature of anti-democratic practices within the university sector in Malawi on a number of grounds. For example, in assuming that valid knowledge can only be established by reference to that which is manifested in experience, it ignores other forms of knowing such as those through which anti-democratic practices can be assessed (see Waghid, 2003). Defining reality as facts in the world would mean that existing university sector practices are objective to form the basis of action limiting the power of self-reflexivity to effect change (Waghid, 2003). Such an approach limits critical analyses as Critical Theory is aimed at seeing reality as what it is now and what it ought to become in future to avoid the givenness of reality as assumed by positivism (see Adorno, 1982; 
Horkheimer, 1978; How, 2003; Marcuse, 1941). Consequently, Critical Theory analysis does not require scientific objectification as advanced by positivism.

Second by positing research as value free, positivism diminishes the power to emancipate societies such as in exploring the nature of anti-democratic practices for the sake of social change in a university sector (see Waghid, 2003). The rejection of values assumes that the running of an education system happens in a vacuum without dominating forces such as power reflected within policy-steerage generally. Research then degenerates to finding facts within the causal law logic and relegating all that cannot be scientifically measured. Such a positivist approach makes it difficult to engage with a deliberative policy-making and practice which is vital in reducing antidemocratic practices or distortions within a sector such as the university.

Third, given the factual interest presented by positivism, its inquiry is based on the functional interest to control, a kind of instrumental reasoning which within Critical Theory is viewed as anti-democratic as it aims at manipulation of society or social control (Habermas, 1984, 1987; Horkheimer, 1978; Neuman, 2006; Rasmussen, 1996, 2004). This is unsuitable as exploring the nature of anti-democratic practices within an institution ought to be guided by honest deliberation and reflexivity to effect change other than just explaining phenomena (Habermas, 1998; How, 2003; Morris, 2006, 2009; Rehg, 1996). The next section discusses the interpretive inquiry and shows that although it is closer to Critical Theory in its approach, it lacks the rigour necessary for an emancipatory project, as set out in this thesis, because of its relativist stance.

\subsubsection{The Interpretive Inquiry}

While positivism was a reaction to the Greco-Roman knowledge premised on Christian religion, interpretivist inquiry was a response to the excess of 
scientific social science (Willis, et al., 2007). It, therefore, comes as a reaction to positivism or a response to objectivism (Willis, et al., 2007). While combining relativist and rationalist perspectives, interpretivist inquiry is opposed to the idea that experience offers the only valid knowledge (Willis, et al., 2007). It, thus, emphasises meaningful social action, socially constructed meaning and value relativism in its approach (Neuman, 2006). The principal goal for research is embedded in the German term, verstehen, meaning, empathetic understanding (Bailey, 2007; Neuman, 2006). Interpretive researchers then are interested in understanding people's internal reasons or motives that shape and guide their actions (Neuman, 2006; Willis, et al., 2007). Neuman contends that "an interpretive approach is the systematic analysis of socially meaningful action through the direct detailed observation of people in natural settings in order to arrive at understanding and interpretations of how people create and maintain their social worlds" (Neuman, 2006, p. 88). As a result, the interpretive approach is in part, largely about how people create meaning in their lives.

Bailey (2007) contends that ontologically, interpretive inquiry assumes that there is no objective reality, but instead members in a setting create their own social reality. Thus, research couched in this paradigm focuses on social relationships as well as mechanisms and processes through which members in a setting create their reality or social worlds (Bailey, 2007; Neuman, 2006). Accordingly, their epistemological belief is that what can be learnt does not exist independently of the researcher (Bailey, 2007; Neuman, 2006; Willis, et al., 2007). The interpretive axiological stance is that research cannot be valuefree as such, research methodology includes interactions with and observations with the respondent (Bailey, 2007). Applied to research, an interpretivist approach proposes that "social scientific knowledge is contingent, context specific and often requires bracketing" (Willis, et al., 2007, p. 48). 
This paradigm offers some meaningful insights for analysis in this thesis in that it rejects the nomothetic stance of positivism and allows for reflection, rationality and discursive communication (Bailey, 2007; Waghid, 2003; Willis, et al., 2007). However, while interpretivist inquiry does manage to replace the nomothetic stance of positivism with interpretive notions such as of meaning making, it fails to go beyond mere interpretation of reality to effecting social change due to its relativist stance (Carr \& Kemmis, 1986; Waghid, 2003). Whereas it is important for people to create meaning, it is pertinent to realise that in their meaning making, they may be influenced by the taken-for-granted beliefs that may sustain instrumental use of reason or simply present distortions in society (Carr \& Kemmis, 1986; Waghid, 2003). Therefore, any analysis, such as of university policy-steerage, management and governance must offer ways of identifying ideological distortions and provide ways of overcoming the taken-for-granted distortions (Carr \& Kemmis, 1986). It can be posited thus, that interpretive theory fails to recognise that many antidemocratic practices within a system such in the university sector in Malawi may not be deliberate choices of actors but due to the taken-for-granted constraints within their socio-political life (see Carr \& Kemmis, 1986; Habermas, 1984, 1987, 1998; Kemmis, 2006). An analysis of the nature of antidemocratic practices within the university sector in Malawi must be concerned with identifying, exposing and changing the taken-for-granted distortions that impede the use of reason to achieve a democratic system (see Carr \& Kemmis, 1986; Habermas, 1984, 1987; Waghid, 2003). Against interpretivist theorising, Carr and Kemmis argue as follows:

A critique cannot simply explain the source of problems that practitioners may face; rather, its purpose is to inform and guide the practices of the actors by indicating the actions that they need to take if they are to overcome their problems and eliminate their difficulties (Carr \& Kemmis, 1986, p. 130).

Interpretive theory, thus, fails to go beyond mere interpretation of reality to effecting social change and so is limited to this study. Critical Theory is more helpful to this thesis as, unlike interpretive theory which views reality in relativist manner, Critical Theory allows the researcher to uncover problems 
and suggest how distortions can be changed to emancipate society. In the following section Critical Theory is discussed. The following paragraphs sketch the beginnings of Critical Theory, the internal contradictions within the theory and elaborate the critique in Critical Theory that informs this thesis. This is important in that it highlights the development of Critical Theory as a theory and shows the source from which this thesis taps to explore the nature of antidemocratic practices within the university sector in Malawi and suggest change.

\subsubsection{Critical Theory}

As noted, Critical Theory is mostly tied to the Frankfurt School in Germany in the 1930s, but can be traced back to Marx, Kant and Hegel (Neuman, 2006). It was, however, elaborated by scholars such as Adorno, Fromm, Marcuse and Horkheimer (first generation theorists) and later by Habermas (second generation theorist) (How, 2003; Rasmussen, 1996, 2004; Willis, et al., 2007). Critical Theory developed as a response to inequities in society (Willis, et al., 2007). It is argued that being sensitive to inequities in society, Critical Theory offers a better way to explore anti-democratic practices in society generally. "Critical Theory is a critical process of inquiry that goes beyond surface illusions to uncover the real structures in the material world in order to help people change conditions and build a better world for themselves" (Neuman, 2006, p. 95). Consequently, a Critical Theory perspective argues that society can be changed for the better. Thus, it is helpful in exploring the nature of antidemocratic practices within policy-steerage, management and governance of university education in Malawi in order effect social change.

The ontological perspective of Critical Theory is that reality is hidden and shaped by aspects which may be historical, socio-political, cultural, ethnic, gender, racial, economic and others (Bailey, 2007; Neuman, 2006). As such, the self evident nature of reality as proposed by positivists for example is 
deceptive. As a result, the epistemological approach in Critical Theory is that what is researched is not independent of the researcher i.e. the researcher produces knowledge through reflexivity normally relating it to oppressive mechanisms (Bailey, 2007). The axiological position is that values are vital to the researcher and that therefore nomothetic stances are ignored (Neuman, 2006). Methodologically, Critical Theorist researchers take macro perspectives to research transcending micro settings such as in considering historical oppressive practices that may affect respondents' world views or settings (Bailey, 2007). Accordingly, Critical Theorist researchers advance epistemologies that can critique ideological distortions (Carr, 2000; Carr \& Kemmis, 1986; Hansen, Berente, \& Lyytinen, 2009; Weaver \& Olson, 2006).

As noted, a Critical Theory perspective views both positivist and interpretive theories as lacking the rigour for emancipation. For example, since positivist theorising rests on causality, a Critical Theory perspective views positivist inquiry as anti-democratic in its use of reason (Neuman, 2006). Further, Critical Theorists argue that positivist inquiry defends the status quo because of assumptions of an unchanging social order that fail to view current social reality as becoming (Neuman, 2006).

Critical Theorists view interpretivist inquiry as being too subjective and relativist, as it celebrates respondents' meaning making as more important than conditions for emancipation (Neuman, 2006). As a result, Critical Theorists argue that interpretive approaches result in a narrow context-bound perception of research (Neuman, 2006). Consequently, they regard interpretive inquiry as amoral and lacking the rigour to exert change within society (Neuman, 2006).

The next discussion details the nature of critique (that which makes Critical Theory go beyond mere interpretation to effecting change in society). The discussion starts with an explanation of critique in the light of the first 
generation Critical Theorists at the Frankfurt School and later the Habermasian linguistic turn. The contention presented is that although the ideas of dialectical reasoning and communicative rationality have different normative foundations, they provide complementary lenses to explore the nature of anti-democratic practices within the university sector in Malawi and suggest ways of emancipation or social change.

\subsection{Critique for first generation Critical Theorists}

What informed critique for the first generation Critical Theorists was the linking of Hegelian Philosophy of History and Marxian historical materialism (How, 2003; Rasmussen, 2004). Hegelian Philosophy was premised on the historical nature of human freedom (Carr, 2000). Hegel introduced the idea of the dialectic involving thesis, antithesis and synthesis which meant that "one element in the process is presupposed by and contains an opposing element as part of its own identity" (How, 2003, p. 4). In Hegelian terms, this means that reality is not static and, as such, reality today only projects what it ought to be in the future (see Carr, 2000; How, 2003; Marcuse, 1941). The contribution made by Hegel to critique in Critical Theory is to show that social reality is a dialectic process which require interrogation to discern what could be a rational and just society (How, 2003). For example, while technology may be seen to improve the human condition, it also presents challenges that may be destructive to social reality (see How, 2003). As such, for first generation Critical Theorists critique meant interrogating those aspects that impede continuous improvement of human condition made aware through dialectic reasoning (How, 2003). First generation Critical Theorists linked this Hegelian idea to Marxian historical materialism as explained next.

For Marx, economic activity was very important in the development of history and consequently for him, human history was simultaneous to human 
production or economic life (Rasmussen, 2004). Thus, it is argued that the linking of this view to the Hegelian dialectic meant that critique was aligned to the history of human production or economic life. Rasmussen argues that according to Marx,

\begin{abstract}
...the problem of modern productive process is that it fails to allow the worker to consolidate herself as a species-being i.e. a person who can function for another human being. Hence the labour process reduces her to an animal, as opposed to a human being, level making her autonomous, competitive and inhuman-cooperating with the productive process and not with other human beings. The point of revolution would be to bring the human being to her full and proper capacities as a being for whom the species would be the end, object and aim (Rasmussen, 2004, p. 6).
\end{abstract}

Making this linkage meant that for the first generation Critical Theorists critique was wedded to the Marxian thesis, emancipation in historical materialism (see How, 2003; Rasmussen, 1996, 2004). In other words, for Marx and his followers, emancipation depended on the use of reason to make the proletariat a species-being. Consequently the dialectic view of interrogating opposites became one premised on the proletariat becoming a species-being or capitalism becoming socialism (How, 2003; Rasmussen, 2004). As such, the research practice prioritised a collection of data meant to show the view that capitalism was pointing towards socialism (How, 2003; Rasmussen, 1996, 2004).

In this thesis, the idea of the dialectic is taken on board but without wedding it to historical materialism or the Marxian orthodoxy. The thesis only accepts that the concept of dialectical reasoning is vital in exploring anti-democratic practices within education systems such as the university sector in Malawi. Following the Hegelian view, the running of universities is viewed as a social reality that requires dialectic interrogating. The next section discusses how critique conceived within the Hegelian-Marxian fashion was challenged by events such as the rise of Fascism and Stalinism and the fall of the idea of the proletariat as becoming species-being. The discussion is helpful in that it 
clarifies why in this thesis; the idea of dialectical reasoning is not wedded to historical materialism.

\subsubsection{Challenges to the Hegelian-Marxian view of critique}

The Hegelian-Marxian perception of emancipation advanced by the first generation Critical Theorists became problematic due to several events such as the rise of Fascism and Stalinism, which were totalitarian ideologies starting from the 1920s (Gentile, 1990; Macridis, 1952). These ideologies manifested instrumental use of reason (Rasmussen, 2004). Second, with time there appeared to be a fragmentation of the workers movement or the proletariat Rasmussen (Briefs, 1939). Consequently, the absence of a cohesive proletariat at this time rendered critique based on the idea of the proletariat becoming a species being, to lack basis (Rasmussen, 1996). In response, Horkheimer attempted to rescue reason as informing critique without wedding it to the idea of the proletariat as becoming a species-being embedded in the Marxian notion of historical materialism (Rasmussen, 1996, 2004).

In trying to reconceptualise critique without wedding it to the Marxian thesis, Horkheimer tried to distance himself from assumptions that required research to be viewed as a reflection of economic life (How, 2003; Rasmussen, 1996, 2004). It is argued that his view shows an attempt to reject positing the proletariat dogmatically as a starting point of emancipatory research (Rasmussen, 1996, 2004). However, many critics argue that Horkheimer failed to disassociate himself completely from the Marxian ideas (Rasmussen, 2004). Rasmussen contends that:

...while dissociating itself from the assumption that truth and proper knowledge was to be rendered through the proletariat, the fundamental tenet of Marxian theory, this treatise on Critical Theory celebrated as valid notions, concepts such as economic determinism, reification, critique of autonomy and social contradictions - 
assumptions derived from the traditional Marxian social theory (Rasmussen, 2004, p. 12).

In this thesis, the Marxian historical materialism is rejected on three major grounds. First, while the Marxian historical materialism posits critique within a particular social class, the proletariat, in this thesis critique is not dependent on a particular social class (Briefs, 1939; How, 2003). Second, while Marxian historical materialism assumes an automatic emancipatory social change, in which with time capitalism changes to socialism (Briefs, 1939; How, 2003), in this thesis change is not viewed as automatic rather as a deliberate effort to create a democratic environment in which the force of reason triumphs over the force of coercion (Habermas, 1984, 1987). Third, while the Marxian historical materialism bases its critique on economic production (How, 2003; Rasmussen, 1996, 2004), in this thesis emancipation is not conceived within such realms other than in the use of reason in a dialectical manner and within communicative rationality.

The next section explains how after the Second World War Horkheimer and Adorno developed pessimism with critique embedded in reason. They began to question whether reason was going to inform any critique capable of emancipation. They began to hold that reason was being used for egoistic practices as manifested by Fascism and Stalinism for example. Understanding reason as used for egoistic tendencies is relevant in this thesis as it helps explain how some university actors use reason for social control in Malawi.

\subsubsection{Horkheimer and Adorno's latter pessimism of reason and critique}

As noted, before the two World Wars, Horkheimer and his associates believed that dialectical reasoning would emancipate society. However, after the Second World War, they became pessimistic, as reason was seen as being used to dominate and control society (instrumental reasoning) rather than offering 
emancipation or social change (Bohman, 1996; Rasmussen, 2004). For these Critical Theorists at this time, the growth of media, bureaucracy, economy, cultural life harboured instrumental reasoning (Bohman, 1996; How, 2003; Rasmussen, 1996, 2004). In this way, reason had become a force for purposes of social control. They began to hold the view that instrumental reason would now become a characteristic of the powerful that would use reason to dominate and control society for their own gains (see Bohman, 1996; Habermas, 1984, 1987; How, 2003; Rasmussen, 1996, 2004; Rehg, 1996). Thus, Horkheimer and Adorno became pessimistic as the very reason that was to inform critique and lead to emancipation had succumbed to unreason to oppression. It is argued that for these Critical Theorists, critique in Critical Theory at this stage had collapsed twice: one from its linkage with Marxism and second to unreason or oppression (Rasmussen, 2004). This discussion is helpful in showing how instrumental reason can be employed in manipulating societies by some actors in the university sector in Malawi.

The next discussion presents critique as advanced by Habermas. Having attempted to show how pessimistic Horkheimer and associates had become, in the following discussion, the interest is to present the revival of the power of reason in informing critique (Rasmussen, 2004). Unlike the Hegelian-Marxian tradition that presents critique in historical materialism, Habermas positions his critique in language and presents what is termed the linguistic turn in Critical Theory (see Habermas, 1984, 1987; Morris, 2009; Rasmussen, 1996; Rehg, 1996).

\subsection{Critique, a Habermasian linguistic turn}

Habermasian critique, as a form of Critical Theory, presents a linguistic turn as he posits critique or the use of reason in language or in speech other than metaphysics (Habermas, 1984, 1987). Habermas views critique in this way, in 
order to re-establish critique in Critical Theory that for him had collapsed with the historical materialism of the Hegelian-Marxian tradition and the pessimistic view of the use of reason (dialectic of enlightenment) expressed by Horkheimer and Adorno (see Bohman, 1996; Forst, 1996; Morris, 2006, 2009; Rasmussen, 1996, 2004). The dialectic of enlightenment describes Horkheimer and Adorno's stance that the very reason that was supposed to be employed for emancipation was being used for egoistic practices especially during the $18^{\text {th }}$ Century enlightenment period (Bohman, 1996; How, 2003; Rasmussen, 2004). The dialectic of enlightenment is used differently from the general idea of the dialectical as advanced by Hegel. Here it denotes the fact the very reason meant for social change, had succumbed to unreason or oppression. Habermas rejected the dialectical nature of critique and that critique could be derived from history as advanced by Hegelian idealist philosophy (Habermas, 1984, 1987; Rasmussen, 1996, 2004). He argues that the philosophy advanced by Horkheimer and associates (the dialectical) viewed the world in terms of subject-object and that in this way reason could only be instrumental (Habermas, 1984, 1987).

For Habermas critique is posited within communicative action (rationality) in which actors seek to reach common understanding and coordinate actions by reasoned arguments, consensus and cooperation rather than instrumental reasoning (Habermas, 1984). He makes the claim that the original mode of language is communication as such discourse embodies emancipation (Habermas, 1984, 1987). Communication provides a basis for critique because language embodies the ideal mutual understanding of actors without use of force (Habermas, 1987). He advances the idea that communicative action is complemented by the theory of the lifeworld (Habermas, 1984, 1987). The concept of lifeworld (lebenswelt) is derived from Husserl's phenomenology and refers to the everyday world as experienced by men and women (How, 2003). Habermas argues as follows:

The lifeworld is given to the experiencing subject as unquestionable. By the everyday lifeworld is to be understood that province of reality 
which the wide-awake and normal adult simply takes for granted in the attitude of common sense. By this taken-for-grantedness, we designate everything which we can experience as unquestionable; every state of affairs is for us unproblematic until further notice (Habermas, 1987, p. 130).

Habermas contends, thus, that subjects acting communicatively always come to an understanding in the horizon of a lifeworld or a cultural, social and shared meaning context. In this thesis, the Habermasian linguistic turn complements the idea of dialectic reasoning.

From the discussion on Critical Theory, the following aspects are important for its application in this thesis:

1. That the idea of dialectical reasoning (without wedding it to historical materialism) is important for interrogating social reality such as the university sector in Malawi

2. That the ideas of dialectic reasoning and communicative action are complementary in exploring anti-democratic practices within the university sector in Malawi in order to effect social change

3. That reason, as an emancipatory tool, can be misused for social control (instrumental reasoning) by some actors within the university sector in Malawi

4. That the lifeworld analysis helps to explain aspects that are taken-forgranted which perpetuate anti-democratic practices within the university sector in Malawi

5. That the ideas of dialectical reasoning and communicative rationality are useful in curbing instrumental reasoning and rationalising the taken-for-granted that impede democratic practices within the university sector in Malawi.

The application of these ideas is given thorough attention in the last chapter in which a theory of university management and governance for Malawian universities is developed in the thesis. 


\subsection{Conclusion}

Chapter 3 has presented Critical Theory as a theoretical framework relevant to this study and has shown how competing paradigms: positivist and interpretive inquires are not rigorous enough to inform this thesis. The chapter presents the argument that positivism over relies on experiential measurable knowledge while interpretivist approach stops at interpreting social reality as relatively viewed by individuals without considering how to emancipate society. The chapter advances a need for employing dialectic reasoning and communicative rationality in policy-steerage, management and governance of university education in Malawi in order to effect social change. 


\section{CHAPTER 4}

\section{Challenges of the university sector in Malawi}

\subsection{Introduction}

This chapter briefly highlights the situation of university education in Malawi. It describes challenges the sector faces and efforts taken by the Malawi Government to revitalise the sector. The chapter starts by brief explanations of the education system and education policy development in Malawi before discussing challenges faced by the university sector.

While discussing challenges and efforts to revitalise the sector, the chapter where necessary, hints that the way some of the challenges are being tackled reflects neopatrimonial attitudes of the big-man syndrome and patron-client mechanisms permeating policy-steerage and governance of the university sector. This argument is fully developed and augmented by chapters 8 and 9 .

The chapter largely contributes to the thesis in three ways: first, by showing that understanding challenges within the university sector by only employing positivist logic blurs an understanding of immeasurable challenges that impede the growth of the sector. Second, by augmenting the general argument made throughout this thesis that although there are efforts to revitalise the university, efforts to explore the nature of anti-democratic practices within the university sector are not given primacy and, third, by providing basis for understanding the proposed social changes in the thesis discussed in chapters 11 and 12. 


\subsection{The education system in Malawi}

The education system in Malawi follows the 8-4-4 pattern, comprising, primary, secondary and tertiary respectively (Maluwa-Banda, 2004). At the end of eight years of primary schooling, successful students obtain the Primary School Leaving Certificate which allows them to go for a four-year period of secondary school level education. After completion of the first two years of the secondary education, successful students obtain the Junior Certificate of Education. Successful students obtain the Malawi School Certificate of Education after completing four years, which enables them to enter tertiary level education. The tertiary sector includes technical and vocational training, primary teacher training institutions and university education. Whereas technical and vocational training and primary teacher training last between two to three years, university sector education usually lasts for four years (Maluwa-Banda, 2004).

\subsection{Education policy in Malawi}

A brief description of the education policy development is helpful in understanding the nature of anti-democratic practices in the university sector in Malawi. Before 1994, two Education Development Plans guided the education sector in Malawi. The first Education Development Plan was formulated for the period of 1973-1980 and the second, for the period 19851995. Currently, university education policy is loosely contained in four documents: the Vision 2020 (Malawi Government, 2000b), the Policy and Investment Framework (Malawi Government, 2000a), the National Education Sector Plan (Malawi Government, 2006b) and the Malawi Growth and Development Strategy (Malawi Government, 2006a). 
The Policy and Investment Framework, which is the major document on education policy generally, outlines education policies for Malawi including for the university education sector for the period of 1995-2012. The policies hinge on increasing access, achieving equitable access, improving quality and relevance of the university education, developing institutional and financial frameworks to sustain the university and encouraging the growth of the private university sector (Malawi Government, 2000a). These proposals have also been echoed by the National Education Sector Plan and the Malawi Growth and Development Strategy, which view education as critical and necessary for the economic and industrial growth and development goal of Malawi (Malawi Government, 2006a, 2006b).

Whereas, as called for in the policy documents, the challenges require addressing, there is a need to understand the nature of anti-democratic practices that permeate the management of the university sector in order to successfully address the concerns of the sector. As argued earlier, challenges presented in policy documents, mostly reflect those that adhere to positivist (measurable) logic which limits understanding of immeasurable problems that demand different kinds of solutions such as those informed by Critical Theory. Challenges of the university sector in Malawi are explained next.

\subsection{Challenges of the university sector in Malawi}

From 1965 to 1999, Malawi had one public university, the University of Malawi. The second public university, Mzuzu University was established by an act of parliament in 1997 and admitted first students in 1999 to increase access to higher education in the country (Mzuzu University, 2005). Access to university education in Malawi (at the time of research) was the lowest in the Southern African Development Community region (Hayward \& Ncayiyana, 2006). Apart from the two public universities, four private universities were operating in the country at the time of research (Malawi Government, 2009). 
The university sector in Malawi shares palpable challenges of sub-Saharan African universities. These challenges include access and equity, quality and relevance, management and governance and financing (see Altbach, 2005; Assié-Lumumba, 2005; Banya, 2001; Banya \& Elu, 2001; Bloom, et al., 2006; Bloom \& Rosovsky, 2007; Johnstone, 2004; Levy, 1999, 2007; Ramphele, 2004; Sawyerr, 2004a, 2004b; Zeleza, 2003, 2005). Each of these challenges is discussed in turn to aid understanding of the proposed social changes in the thesis discussed in chapters 11 and 12.

\subsubsection{Access problems}

In Malawi, a sharp increase in the number of students seeking to enrol in the university has posed a challenge for the university sector (Hayward \& Ncayiyana, 2006). In all sub-Saharan African countries, demand for university education is steadily increasing posing resource related challenges in universities (Teferra \& Altbach, 2004). In Malawi, the problem is partly exacerbated by the fact that without proper preparation, the country adopted the Free Primary Education Policy in 1994, which has burgeoned the number of students wanting to get to university (see Malawi Government, 2000a). The stress on primary education in Africa was supported by the World Bank without corresponding efforts to strengthen the capacity of the university sector (Brock-Utne, 2003; Tilak, 2005).

University education in Malawi is extremely competitive and only a limited number of qualified students get enrolled annually (Bloom \& Rosovsky, 2007; Malawi Government, 2000a). By 2006, only about one fourth of students could be admitted to the university annually from about 4, 000 applicants who qualified for university education (Hayward \& Ncayiyana, 2006). By 2006 the Gross Enrolment Rate (GER) for the universities was at $0.3 \%$ and for the general tertiary at $0.5 \%$ of the $18-23$ age group (Bloom, et al., 2006; Malawi 
Government, 2000a, 2006b). The university sector in Malawi had about 7000 students in all study levels against a population of about 14 000, 000 in 2006 (Hayward \& Ncayiyana, 2006). This shows a very elitist admission if compared to other countries of the region such as Swaziland and Botswana each with a population of about 1, 500, 000 and a public university enrolment of around 15, 000 each in the same year (Hayward \& Ncayiyana, 2006).

The main limitation to access is due to the statutory provision of 1964 that demanded the university to guarantee free accommodation to all students (Hayward \& Ncayiyana, 2006). As a result, bed space became the absolute limiting factor to the number of students that could be admitted annually from the secondary school sector (Hayward \& Ncayiyana, 2006). Since (as at the time of research) private universities had followed the traditional provision of guaranteeing accommodation to almost all students, it seemed unlikely that Malawian university education would substantially increase access.

However, in a bid to increase access to university education, in 2002, the University of Malawi introduced the parallel programme in addition to the normal students who qualify for bed space (Hayward \& Ncayiyana, 2006). Parallel students are admitted to the university on condition that they provide their own accommodation and food and pay higher fees. This arrangement is expensive for most students and it heavily favours the wealthy, as such, it is not an option for many.

University participation for female candidates is more limited than for male candidates (Malawi Government, 2000a, 2009) (see Table 5). The government proposes to bring about equitable access by increasing enrolment for females candidates to $50 \%$ of the total enrolment (Malawi Government, 2000a). There are a number of reasons why female enrolments are low in Malawian universities such as high female dropout rates which reduce the percentage of females who enter the Malawi School Certificate of Education and 
consequently, the university and other tertiary institutions (Malawi Government, 2009). Second, accommodation in universities is mostly designed for male students (Malawi Government, 2009). Table 5 shows total university enrolment for the period 2003 to 2008 and the corresponding enrolment percentage.

Table 5: University enrolment by gender

\begin{tabular}{|l|l|l|l|l|l|}
\hline Year & Male & Female & Total & Male \% & $\begin{array}{l}\text { Female } \\
\text { \% }\end{array}$ \\
\hline 2003 & 3,262 & 1,397 & 4,659 & 70 & 30 \\
\hline 2004 & 3,877 & 1,706 & 5,583 & 69 & 31 \\
\hline 2005 & 4,208 & 2,051 & 6,259 & 67 & 33 \\
\hline 2006 & 4,947 & 2,410 & 7,357 & 67 & 33 \\
\hline 2007 & 5,686 & 2,788 & 8,474 & 67 & 33 \\
\hline 2008 & 5,964 & 3,118 & 9,082 & 66 & 34 \\
\hline
\end{tabular}

Source: Malawi Education Country Status Report, 2009

Table 5 shows a general increase of university enrolment for the period 2003 to 2008 for both male and female candidates. The Table shows that by 2008 the percentage increase of female candidates of the total enrolment is 34 . This shows that while the Malawi Government's policy on equity is to increase female participation to $50 \%$ of the total enrolment by 2012 , given the enrolment growth rate, this may not be achieved by 2012 .

The other government proposed policy on equity concerns increasing the participation of students from disadvantaged groups (geographical, physical disabilities and socio-economic groups) (Malawi Government, 2000a). As a strategy to achieve this policy, the government proposes a quota system to be put in place on admission of students from educationally disadvantaged groups (Malawi Government, 2000a). However, the policy is not clear on what 
it means by educationally disadvantaged group and does not provide any explanation. As is discussed in chapter 9, however, the government has introduced a quota system of university selection policy based on district of origin and district population. The problem is that the policy has been put in place without deliberative mechanisms and is viewed to harbour neopatrimonial aspects of the big-man syndrome and patron-client mechanism as discussed in chapter 2. Chapter 9 provides a detailed discussion of the policy.

\subsubsection{Problems of quality-provision of university education}

Quality as a notion is contested (Harvey \& Green, 1993). In Education policy documents in Malawi, the idea of quality is linked to the availability of teaching and learning resources, adequate staffing and relevance of the courses (Malawi Government, 2000a, 2006b).

It is argued that the scarcity of teaching and learning resources limits the provision of quality university education in Malawi (Malawi Government, 2000a). The government advises universities to diversify their sources of income to avert this problem (Malawi Government, 2000a, 2006b). While diversifying sources of income would be practical, it has the potential to facilitate market oriented university governance, which might affect the public good conception of the university as argued in chapter 7 (see Giroux, 2003).

Staffing has been a serious problem in the university education sector and a lack of qualified personnel affects the quality of teaching and learning and stifles research capacity within universities (Malawi Government, 2000a, 2006b). Lack of adequate qualified personnel compels universities in Malawi to use staff associates and assistant lecturers to teach courses (Malawi 
Government, 2009). The use of staff associates who are not fully qualified to lecture at university level reveals that universities fail to attract enough qualified lecturers (Malawi Government, 2009). To attract qualified personnel, the government policy is to improve the motivation of the staff by improving work conditions such as increasing real wages and professional benefits for faculty members (Malawi Government, 2000a). While there is a need to improve the motivation of staff by improving work conditions, there is a need to interrogate anti-democratic practices that stem from power relations, which demoralise faculty members as revealed in chapters 8 and 9 of this thesis.

The lack of relevance of the courses is viewed as contributing to poor quality university education (Malawi Government, 2000a). The government aims at achieving relevance for the courses offered at university level in two ways: by encouraging institutions to review their teaching and research programmes and promoting institutional responsiveness to the needs of the Malawian society and by strengthening Science and Technology and HIV/Aids awareness programmes (Malawi Government, 2000a, 2006b). While designing courses to be responsive to the Malawi society is important, the government ought to guard against reducing university education to fulfilling only the requirements of the labour market, which has the potential of limiting critical aspects of university education (see Giroux, 2003).

\subsubsection{Problems of management and governance of the university sector}

In policy documents, problems of management and governance of the university sector in Malawi are associated with a lack of defensible higher education policy frameworks such the National Council for Higher Education and those associated with the governance of the collegiate nature of the University of Malawi (Malawi Government, 2000a). 
The government proposes the following policies to address issues of management and governance in Malawian universities: enacting a University Education Act to steer national objects of the university education and establishing a National Council for Higher Education to oversee policy development and encourage private tertiary education and ensure its quality (Hayward \& Ncayiyana, 2006; Malawi Government, 2000a, 2006b). Further, the government proposes decentralising the University of Malawi governance and promoting joint collaboration between universities and the Ministry with regard to university education development generally (Malawi Government, 2000a, 2006b).

While defensible policy frameworks may be useful in the management and governance of the university sector, it is how they shall be used to steer policy that is most important and seems not to be reflected in government proposals. The policy propositions by the Malawi Government reflect the positivist logic in assessing problems and solutions associated with the management and governance of the university sector. While employing the positivist logic is useful, there is a need to also assess problems by employing Critical Theory, which helps to uncover hidden or immeasurable anti-democratic practices that permeate policy-steerage and university governance as discussed in this thesis.

\subsubsection{Problems of financing university education}

Public universities in Malawi are funded or subvented by the government (Malawi Government, 2009). University funding is under a separate budget, independent of the Ministry of Education and Vocational Training, although universities report to this ministry (Hayward \& Ncayiyana, 2006). Funding has proved to be unpredictable and without proper mechanisms (Hayward \& Ncayiyana, 2006). It is argued in this thesis that the lack of proper funding mechanisms facilitates the big-man syndrome (stemming from state 
presidents who are also university chancellors) to permeate university policysteerage (see chapter 9). The provision of university education in Malawi is expensive (Bloom \& Rosovsky, 2007; Ng'ethe, Subotzky, \& Afeti, 2008). As of 2008, among its neighbours, Malawi had the lowest GDP per capita at USD 257 in comparison to Mozambique (USD 397), Zambia (USD 898) and Tanzania (USD 363) (IMF World Economic Outlook Database, 2008.). However, Malawi spends relatively more per capita on university education than some neighbouring countries. (Malawi Government, 2000a; Sayed, Mackenzie, Shall, \& Ward, 2008).

Funding is crucial and most of the time universities do not get the required amounts for their operations, as shown in Table 6. Universities are expected to source for more resources on their own, which presents a very big challenge in running universities in Malawi. By 2006, the Malawi Government approved student fees of 25000 Kwacha (US\$ 170) per annum at the University of Malawi and 55000 Kwacha (US\$ 390) at Mzuzu University (Hayward \& Ncayiyana, 2006). However, parallel and non residential students pay 100, 000 Kwacha (US\$ 689) at the University of Malawi and 150, 000 Kwacha (US\$ 1 034) at Mzuzu University respectively. Table 6 shows the University of Malawi funding from 1999/2000-2004/2005. 
Table 6: The University of Malawi funding from 1999/2000-2004/2005

\begin{tabular}{|l|l|l|l|l|l|}
\hline Year & $\begin{array}{l}\text { Amount } \\
\text { requested by } \\
\text { the } \\
\text { university } \\
\text { (excluding } \\
\text { own } \\
\text { generated } \\
\text { income) in } \\
\text { Malawi } \\
\text { kwacha (MK) }\end{array}$ & $\begin{array}{l}\text { Amount } \\
\text { granted by } \\
\text { the } \\
\text { government } \\
\text { in Malawi } \\
\text { kwacha } \\
\text { (MK) }\end{array}$ & $\begin{array}{l}\text { Percentage } \\
\text { of } \\
\text { government } \\
\text { funding of } \\
\text { the total } \\
\text { cost }\end{array}$ & $\begin{array}{l}\text { Amount } \\
\text { generated } \\
\text { by the } \\
\text { university } \\
\text { in Malawi } \\
\text { kwacha } \\
\text { (MK) }\end{array}$ & $\begin{array}{c}\text { Actual } \\
\text { expenditure } \\
\text { in Malawi } \\
\text { kwacha } \\
\text { (MK) }\end{array}$ \\
\hline $1999 / 2000$ & $\begin{array}{l}680000000 \\
\text { (Mno }\end{array}$ & & & \\
\hline $2000 / 2001$ & 1158134395 & 500000000 & 43.17 & 58300722 & 725003699 \\
\hline $2001 / 2002$ & 1431496659 & 659529966 & 46.07 & 168546789 & 832178691 \\
\hline $2002 / 2003$ & 1689072972 & 891804448 & 52.99 & 201669095 & Not provided \\
\hline $2003 / 2004$ & 2393195669 & 1450894821 & 60.63 & 303249782 & 1331984105 \\
\hline $2004 / 2005$ & 2977251628 & 1932177836 & 64.9 & 358162592 & 2290340428 \\
\hline
\end{tabular}

Source: The University of Malawi, University Office Statistics, Annexe 3, 2007

Table 6 shows that the University of Malawi did not get the requested amount of subvention for the period from 1999/2000-2004/2005. Mzuzu University financing also shows a similar trend. In general, public universities are given about $50 \%$ subvention of what they request from government and they have to augment this with tuition fees and other income (Malawi Government, 2009).

Tuition fees are the major source of income in the private universities. Students pay 320, 000 Kwacha (US\$ 2 206) at the Catholic University of Malawi and 230, 000 (US\$ 1586 ) Kwacha at the University of Livingstonia per year (Malawi Government, 2009).

Government funding to universities in Malawi is not only undependable but also inadequate to run universities (Hayward \& Ncayiyana, 2006). A lack of proper funding mechanisms makes universities to be at the mercy of state 
presidents to authorise funding from the government (see chapter 9). Waiting for presidents to authorise funding levels gives them unprecedented power over the running of universities. It is argued that the dependence on the presidents to improve funding for the university sector facilitates the big-man syndrome (stemming from state presidents who are also university chancellors) to permeate university policy-steerage (see chapter 9). This argument is developed in chapter 9.

\subsubsection{Student financing}

Student financing has been very controversial in Malawi's university education sector (Hayward \& Ncayiyana, 2006; Malawi Government, 2009). At first students were provided with a free book allowance (Hayward \& Ncayiyana, 2006). Changes initiated around 1994 demanded that students get loans from the government, which they were supposed to pay back after graduation (Malawi Government, 2009). However, due to lack of recovery mechanisms by the government, it was difficult to recover loans from graduates (Hayward \& Ncayiyana, 2006; Malawi Government, 2009). Currently the Government has introduced a student loan scheme managed by the Public Universities Students Loan Trust to facilitate fee and book or stationery needs of students. However, the loan trust fund lacks proper repayment mechanisms, prompting students to consider loans as grants (Hayward \& Ncayiyana, 2006; Malawi Government, 2009).

The main purpose of the loan scheme is to improve access especially of the needy students from poor backgrounds (Malawi Government, 2009). However, with lack of proper operational mechanisms the needy do not really benefit from the scheme (Hayward \& Ncayiyana, 2006; Malawi Government, 2009). The problem is that the loan trust fund finds it difficult to establish working criteria for needy students such that almost every student qualifies to get loans (Malawi Government, 2009). 
While there are several issues surrounding the loan scheme as noted, the major problem revealed in this thesis is the way the disbursement of students' loans is done by university administrators within universities. The disbursement of students' loans is a source of strife within universities and reflects the neopatrimonial attitude of the big-man syndrome permeating the university sector. This argument is developed in chapter 8.

\subsection{The University of Malawi (UNIMA)}

The University of Malawi is a collegiate university comprising the following institutions: Chancellor College, Bunda College of Agriculture, Kamuzu College of Nursing, the Malawi Polytechnic and the College of Medicine. Chancellor College, situated in Zomba is the main campus of the University of Malawi with 23 departments under five faculties: Education, Humanities, Law, Science and Social Science. Bunda College of Agriculture in Lilongwe specialises in Agricultural and Environmental courses. Kamuzu College of Nursing in Lilongwe prepares graduate nursing and midwifery personnel. The Malawi Polytechnic in the commercial city of Blantyre focuses on Science and Technology, Engineering and Commerce. Also in Blantyre is the College of Medicine which consists of a single faculty that offers a range of medical courses. The university has five centres: Centre for Agricultural Research and Development; Centre for Education Research and Training; Centre for Language Studies; Centre for Social Research and Centre for Water, Sanitation, Health and Appropriate Technology Development and has a unit for Gender Studies.

The University of Malawi model emerged in the early 1960s, partly out of economic considerations and partly as a result of historical exigencies (Loken, Asher, \& Lesire, 1977). On economic grounds, it would have been unrealistic to launch different types of tertiary institutions separately. It was thus, a realistic policy both on economic and educational grounds to entrust the university 
with the responsibility for almost all tertiary education in the country. The university of Malawi was founded under the University of Malawi Provisional Council in October 1964 which was replaced by the University of Malawi Act in 1974 (The University of Malawi, 2004).

In 2008 the University of Malawi had 6, 257 full time students out of which 26 were from the Southern African Development Community region and five from other international regions (Robbins, Strydom, \& Hoosen, 2009). While masters degrees are offered in most subjects at this university, PhDs are only offered at Chancellor College and only in the following areas: Theology, English, Chemistry, Biology and Economics (Malawi Government, 2009). Table 7 shows the staff profile at the University of Malawi.

Table 7: Staff ${ }^{3}$ profile at the University of Malawi in 2008

\begin{tabular}{|l|c|l|l|l|c|}
\hline $\begin{array}{l}\text { Staff } \\
\text { designation }\end{array}$ & $\begin{array}{l}\text { UNIMA Bunda } \\
\text { College }\end{array}$ & $\begin{array}{l}\text { UNIMA } \\
\text { Chancellor } \\
\text { College }\end{array}$ & $\begin{array}{l}\text { UNIMA } \\
\text { Poly }\end{array}$ & $\begin{array}{l}\text { UNIMA } \\
\text { College of } \\
\text { Medicine }\end{array}$ & $\begin{array}{l}\text { UNIMA College } \\
\text { of Kamuzu } \\
\text { Nursing }\end{array}$ \\
\hline Professor & 12 & 12 & 1 & 6 & 0 \\
\hline $\begin{array}{l}\text { Associate } \\
\text { Professor }\end{array}$ & 10 & 10 & 2 & 25 & 11 \\
\hline $\begin{array}{l}\text { Senior } \\
\text { Lecturer }\end{array}$ & 24 & 24 & 33 & 62 & 25 \\
\hline $\begin{array}{l}\text { Lecturer } \\
\text { Assistant } \\
\text { Lecturer }\end{array}$ & 79 & 119 & 94 & 39 & 0 \\
\hline $\begin{array}{l}\text { Staff } \\
\text { Associate }\end{array}$ & 20 & 6 & 43 & 0 & 38 \\
\hline
\end{tabular}

Source: Malawi Government (Education Sector Country Status Report, 2009)

${ }^{3}$ Highest staff qualifications and their designations are as follows: Professors and Associate Professors usually hold PhDs and have substantial publications. Senior lecturers may hold masters degrees or PhDs. Lecturers hold masters degrees. Assistant lecturers hold first degrees with some years of teaching experience. Staff Associates hold first degrees and are employed pending further training. 
While most staff members have their first degrees from Malawi, most of them have obtained their postgraduate degrees mainly from England, the United States and South Africa.

\subsection{Mzuzu University (MZUNI)}

As noted, the need for a second public university in Malawi, Mzuzu University, was expressed in 1994 owing to the high demand for higher education and the need for an elaborate university education that answers to the needs of the country (Mzuzu University, 2006). The university was finally established by an Act of Parliament in 1997 as second national (public) university in Malawi and admitted the first students to the Faculty of Education in January 1999 (Mzuzu University, 2006). Mzuzu University is autonomous and independent of the existing collegiate University of Malawi. The university which in 1999 had only the Faculty of Education had by 2010 three other faculties: the Faculty of Health Sciences, the Faculty of Information Science and Communication and the Faculty of Environmental Sciences. The university has centres for Open and Distance Learning, Continuing Education; Test and Training Centre for Renewable Technologies (TCRET); Security Studies; and Environmental Education, Training and Research.

In 2008, enrolment at Mzuzu University was 1,612 out of which only five were from the Southern African Development Community region and five from other international regions (Robbins, et al., 2009). Apart from undergraduate courses, the university offers masters degrees in Information Science and Cryptography and Religious Studies and PhDs in Religious Studies. Table 8 shows the staff profile at Mzuzu University. 
Table 8: Staff profile at Mzuzu University in 2008

\begin{tabular}{|l|c|}
\hline Staff designation & Number of Staff \\
\hline Professor & 2 \\
\hline Associate Professor & 6 \\
\hline Senior Lecturer & 24 \\
\hline Lecturer & 54 \\
\hline Assistant Lecturer & 8 \\
\hline Staff Associate & 35 \\
\hline
\end{tabular}

Source: Malawi Education Sector Country Status Report, 2009

\subsection{The University of Livingstonia (UNILIA)}

The University of Livingstonia owned by the Synod of Livingstonia under the Church of Central Africa Presbytery, opened in 2003 in the Northern region of Malawi. It is a collegiate with the Livingstonia Technical College and a School of Education located in Livingstonia in Rumphi district and three other institutions: the College of Commerce, Ekwendeni College of Nursing and the Livingstonia Theological College at Ekwendeni near Mzuzu City in Mzimba district.

In 2008 the University of Livingstonia (School of Education) had 147 students against 14 members of staff (Robbins, et al., 2009). Most of the lecturers were adjunct especially from Mzuzu University, as such it is difficult to show a staff profile for this university. There is generally a lack of information due to poor information management facilities at the university, as such; information provided for this university is only from the College of Education. 


\subsection{The Catholic University of Malawi (CUNIMA)}

The Catholic University of Malawi was officially opened in 2006 in Blantyre, in the Southern region of Malawi. Owned by the Catholic Church in Malawi, the university has three faculties: Education, Social Science and Health Sciences and a Centre for Legal Studies. In 2008, the Catholic University had 363 students against 27 members of staff. Table 9 shows staff profile at the Catholic University of Malawi.

Table 9: Staff profile at the Catholic University of Malawi in 2008

\begin{tabular}{|l|c|}
\hline Staff designation & Number of staff \\
\hline Professor & 2 \\
\hline Associate Professor & 0 \\
\hline Senior Lecturer & 9 \\
\hline Lecturer & 8 \\
\hline Assistant Lecturer & 2 \\
\hline Staff Associate & 6 \\
\hline
\end{tabular}

Source: Malawi Education Sector Country Status Report, 2009

\subsection{Conclusion}

Chapter 4 has briefly described the university sector and explained the major challenges faced by this sector in Malawi. While discussing challenges and efforts to revitalise the sector, the chapter where necessary, has hinted that the way some of the challenges are being tackled reflects neopatrimonial attitudes of the big-man syndrome and patron-client mechanisms permeating policysteerage and governance of the sector to be discussed fully in chapters 8 and 9 . The chapter has contributed to the thesis by arguing that understanding challenges within the university sector by employing positivist logic only 
impedes an understanding of immeasurable challenges such as those that can be uncovered through Critical Theory. It has thus, augmented the general argument made throughout this thesis that although there are efforts to revitalise the university, efforts to explore the nature of anti-democratic practices that hinge on power relations within the sector are not given primacy. All in all, the chapter has provided the basis for understanding the proposed social changes within the sector in the thesis. 


\section{CHAPTER 5}

\section{Methodology of the study}

\subsection{Introduction}

To explore the nature of anti-democratic practices within the university sector in Malawi and suggest ways of emancipation or social change, this thesis employs qualitative inquiry grounded on Critical Theory. Since qualitative aspects of methodology shall be discussed from the stance of Critical Theory, they shall be dealt with differently from qualitative aspects that are founded on the interpretive logic which does not aim at emancipation (see Carr \& Kemmis, 1986; Habermas, 1984). This chapter defines and situates qualitative inquiry by explaining critical-qualitative inquiry and the role of reflexivity in critical-qualitative research; describes the study population; explains data collection methods and analysis and, finally, examines ethical issues in this thesis.

\subsection{Defining and situating qualitative inquiry}

The definition of qualitative research is contested as it connotes a complex family of terms such as foundationalism, post-structuralism and others (Denzin \& Lincoln, 2003). Punch (2005), describes qualitative research as representing a huge variety. It is argued in this thesis, therefore, that the usage of the term qualitative inquiry mostly varies with the nature of research undertaken such as whether it follows an interpretive framework or Critical Theory.

Denzin and Lincoln (2003, p. 13) suggest that: "qualitative researchers stress the socially constructed nature of reality, the intimate relationship between 
the research and what is studied, and the situational constraints that shape inquiry emphasising the value-laden nature of inquiry". In this way, qualitative research is interested in socially constructed meaning that people bring to the researcher as opposed to discovering the real world, out there (Creswell, 2002; Patton, 2002). Meaning construction by the researcher is helpful in knowledge production (see Bailey, 2007; Neuman, 2006). In allowing for knowledge production by the researcher, qualitative inquiry is appropriate for this thesis as it enables the researcher (using Critical Theory) to produce necessary knowledge to explain respondents' constraints that perpetuate anti-democratic practices within the university sector in Malawi and suggest opportunities for change (see Carr \& Kemmis, 1986).

Qualitative researchers, in their meaning construction, employ particular methods of data collection such as in-depth-semi-structured interviews and analysis of policy documents that are to form a rich picture of the nature of anti-democratic practices within the university sector in Malawi in this thesis (see Bryman, 2008; May, 1997; Punch, 1998, 2005). The next discussion explains critical-qualitative inquiry based on Critical Theory.

\subsubsection{Critical-qualitative inquiry}

As noted, Critical Theory has an emancipatory project. A Critical Theorist, thus, is one who advances a form of social criticism in his/her work which has the potential to lead to emancipation (Kincheloe \& McLaren, 2008). Similarly, this thesis offers a form of social critique by exposing the nature of anti-democratic practices and their sources within the university sector in Malawi. Kincheloe and McLaren articulate a Critical Theory inquiry as follows:

Critical research can be understood in the context of the empowerment of individuals. Inquiry that aspires to the name of critical must be connected to an attempt to confront the injustice of a particular society or sphere within the society. Research thus becomes a transformative endeavour unembarrassed by the label political and 
unafraid to consummate a relationship with an emancipatory consciousness (Kincheloe \& McLaren, 2008, p. 406).

Viewed as above, Critical Theory is concerned with issues of power and justice and the ways social systems are constructed (Kincheloe \& McLaren, 2008). In this thesis, Critical Theory enables the researcher to expose misuses of power within the university sector in Malawi and identify opportunities for social change. In this way this thesis is transformative (Kincheloe \& McLaren, 2008).

As argued in chapter 3, adhering to Critical Theory, the thesis presents an ontology that holds that social reality is shaped by macro issues such as historical, social, cultural and economic factors (see Bailey, 2007). The thesis, thus, in its methodology, also pays attention to macro issues that seem to shape the nature of anti-democratic practices in Malawian universities such as neopatrimonial attitudes discussed in chapter 2 . The next paragraph briefly describes the role of reflexivity in critical-qualitative research.

\subsubsection{The role of reflexivity in critical-qualitative research}

Reflexivity in social research is contested (D'Cruz, Gillingham, \& Melendez, 2007; McCabe \& Holmes, 2009). The general starting point is that "reflexivity in research can function as both a control for researcher bias and as a tool for gaining new depths in research" (McCabe \& Holmes, 2009, p. 1521). This is not surprising given the value-laden nature of social research. In Critical Theory, Waghid (2003) argues that reflexivity has two dimensions that ought to be embraced simultaneously to achieve an emancipatory project: first, interrogating one's personal and theoretical assumptions, second, investigating how these assumptions can help to solve distorted practices. Following on from Waghid, reflexivity in this thesis concerns the researcher's personal and theoretical assumptions drawn from Critical Theory which help the researcher to expose the nature of anti-democratic practices within the university sector in Malawi in order to effect social change. Reflexivity in 
Critical Theory is, thus, a condition for achieving emancipation. A brief explanation of the study population is discussed next.

\subsection{The study population}

A total of 20 respondents were interviewed for this thesis. As already noted, to gather data, the research targeted university administrators or managers, selected government policymakers, leaders of selected Malawian civil society, leaders of staff and student unions in Malawian universities and the international finance community represented by the World Bank and the International Monetary Fund. These groups were targeted because of their connection, though in varied ways, to the university sector in Malawi. Their involvement in the university sector was seen to be helpful in answering the research questions that hinge on exploring the nature of anti-democratic practices within the university sector in Malawi.

However, the international agencies did not accept invitations for formal interviews by the researcher. While the leader of the education section of the World Bank in Malawi referred the researcher to the 2009 Malawi Education Country Status Report publication that the World Bank funded, the leader of the International Monetary Fund in Malawi offered an informal discussion in which he elaborated his organisation's general involvement in education in Africa generally including in Malawi. As such, the major discussion on external influence in university education provided in this thesis is based on data from university administrators or managers, selected government policymakers, leaders of selected Malawian civil society, leaders of staff and student unions in Malawian universities, analyses of international policy discourses and analysis of policy documents. 
Although the research had targeted two representatives of the civil society, only the leader of the Centre for Human Rights and Rehabilitation was reached. The leader of the Malawi Economic Justice Network could not find appropriate time for an in-depth interview. All in all, despite the mentioned constraints, the researcher managed to gather enough data to aid a transformative research analysis as is required within Critical Theory (Cho \& Trent, 2006).

\subsubsection{Sampling of research respondents}

This thesis employed deliberate or purposive sampling to get research respondents. Purposive sampling entails that the researcher deliberately selects respondents with some purpose or focus in mind (Punch, 1998, 2005). With purposive sampling the research population is less significant than the criteria of identifying the respondents since qualitative research does not aim at generalising results (Bryman, 2008; Punch, 1998, 2005). Purposive sampling was useful in selecting the institutions and respondents with knowledge that would lead to exploring the nature of anti-democratic practices within the university sector in Malawi.

\subsubsection{Research population from the Malawi Government}

From the Malawi Government, data were collected from the directors of education and development from ministries of Education and Vocational Training and Development Planning and Cooperation respectively.

The Ministry of Education and Vocational Training was selected because public universities are answerable to this ministry although, as noted earlier, public universities are funded through a separate budget (see Hayward \& Ncayiyana, 2006). The Ministry of Education and Vocational Training is responsible for 
the development of education policy including that of higher education (see Malawi Government, 2000a). It was viewed as pertinent to interview the director of education to explore the nature of anti-democratic practices within the university sector originating from the Malawi Government.

The Ministry of Development Planning and Cooperation was selected because of its role in providing policy advice and technical support to government on economic, social and development policy to which education is viewed as centrepiece in Malawi (Malawi Government, 2000a, 2006a, 2006b). Further, the Ministry of Development Planning and Cooperation, being responsible for development policy plays a liaison role between the Malawi Government and the international financing community on general policy that eventually affects the university sector in Malawi. As such, it was helpful to consult the Ministry of Development Planning and Cooperation in order to explore the nature of anti-democratic practices within the university sector stemming from the international finance community.

\subsubsection{Research population from the university sector}

At the time of research, Malawi had two public universities, the University of Malawi and Mzuzu University, and four private universities, The University of Livingstonia, the Catholic University of Malawi, Share World University, and the Adventist University of Malawi (see Malawi Government, 2009). This research targeted the two public universities and two private universities: the University of Livingstonia and the Catholic University of Malawi.

The two public universities were chosen because they are the only public universities and were relevant to an analysis of the nature of anti-democratic practices within the university sector in Malawi. The two private universities were selected because they have structures similar to the public universities. 
In general, the research purposively targeted universities that were relevant in providing information that could lead to an analysis of the nature of antidemocratic practices within the university sector in order to identify opportunities for social change.

Seven respondents were interviewed at the University of Malawi: the University Registrar, the Chairperson of Council, the Chairperson of the Academic Staff Union, the principals of three colleges (Chancellor, Bunda, and Medicine) and the Chairperson of Students' Union. Five respondents were interviewed at Mzuzu University: the Deputy Vice Chancellor, the University Registrar, The Chairperson of Council, the Chairperson of Mzuzu University Academic Staff Union and the Chairperson of the Students' Union. Two respondents were interviewed at the University of Livingstonia: the Acting Vice Chancellor and the Chairperson of the University of Livingstonia Students' Union. Three respondents were interviewed at the Catholic University: the Vice Chancellor, the Chairperson of the Catholic University of Malawi Staff Social Welfare and the Chairperson of the Students' Union.

\subsubsection{Research population from other Civil Society Organisations}

Up to the time of the study in 2009, there was a weak civil society or Non Governmental Organisation that directly worked with the university sector in Malawi. However, civil society organisations such as the Centre for Human Rights and Rehabilitation have commented on government policy on university education on some occasions. The researcher interviewed the former director of the Centre for Human Rights and Rehabilitation.

The study, selected the Centre for Human Rights and Rehabilitation because of its role as a commentator on government university policy. Since this centre is a human rights organisation that advances respect for human rights, equality 
and impartiality while promoting good governance in Malawi, it was well placed for discussions on democracy and policy praxis of the nature advanced throughout this thesis.

\subsubsection{Accessing respondents}

Face to face contacts and personalised invitations are the practical and accepted practice within Malawi for research (see Mtika, 2008). Respondents were visited in order to have face to face contact with the aim of personalising invitations. They were provided with letters inviting them to participate in the research, information sheets and consent forms. This was done to avoid the long delays that arise in Malawi when letters are sent to respondents before face to face contact (see Mtika, 2008). Personalised invitations sped up research activities, which was vital as there was limited time to collect data and return to New Zealand to continue PhD studies. Arrangements were made to interview those individuals who agreed to participate in the research. However, although the invitations were personalised and dates for interviews agreed upon with respondents, in some instances, respondents did not turn up or had to be reminded about the interview schedule. In other cases, dates and time for interviews had to be rearranged. In some cases, the respondents changed dates and time, making it difficult for the researcher to stay in the areas for long due to limited resources. In these cases, interviews were cancelled. For this reason (among others) instead of interviewing 29 respondents as planned, only 20 respondents were interviewed.

\subsection{Data collection methods}

In order to explore the nature of anti-democratic practices within the university sector in Malawi the study employed in-depth semi-structured interviews. In-depth, semi-structured interview is mostly a qualitative 
research technique that require undertaking intensive individual interviews with a small research population to investigate their perspectives on a particular research problem (Boyce \& Neale, 2006).

Usage of in-depth, semi-structured interview method presupposes that a dialogue can emerge between the researcher and the interviewee (Bailey, 2007). According to Flick (2006), the dialogue is facilitated by a subjective theory, which views interviewees as having a broad knowledge about the research question. As such, to explore the nature of anti-democratic practices within the university sector in Malawi, the researcher presupposed that respondents had broad knowledge about the university sector in Malawi. The general expectation, thus, was that respondents could express their knowledge of the university sector spontaneously in answering questions about the nature of anti-democratic practices within the university sector (see Flick, 2006). This method of data collection enabled the researcher to interrogate anti-democratic practices and their sources within the university sector.

A list of guiding questions was developed in order to facilitate the dialogue required by using the in-depth semi-structured interview method. To enhance the dialogue, prior to interviews respondents were given a list of themes that the interview was going to cover. This was important to respondents as it helped them to anticipate what the interview was to be like and prepared them to engage with the questions critically.

The researcher considered setting up expectation as vital, as such, in opening in-depth interviews; introductory questions were broader to provide space for probing issues that respondents were bringing out concerning the nature of anti-democratic practices within the university sector in Malawi (see Yates, 1998). Starting in-depth interviews with broader questions enabled the researcher to develop ideas that were emerging during the research 
discussion (Yates, 1998). To facilitate dialogue and to enrich the research discussion, the researcher provided respondents with flexibility on how to reply to the research questions (Bryman, 2008). Providing more flexibility in answering in-depth interview questions allowed for more probing and exploration of the topic under study (Bryman, 2008).

While aware that in-depth interviews have the advantage of providing detailed information and a more relaxed atmosphere in which to collect data, the researcher was also aware that they can be prone to bias as respondents may be informed by distortions that stem from the taken-for-granted realms of their social life. Where biases reveal to be stemming from the taken-forgranted aspects revealed in this thesis, the thesis provides ways of counter arguments. Providing counter arguments is important in Critical Theory as it allows the researcher (in meaning making) to offer critique other than to accept respondents' view points as relative truths as is normally assumed in interpretive research (see Bailey, 2007; Neuman, 2006).

In-depth-semi-structured interviews may be expensive and time consuming (Boyce \& Neale, 2006). In this study the researcher travelled long distances to arrange interviews and conduct them. In some cases, the researcher had to stay in places longer than expected increasing expenses on accommodation and food. Where necessary, the researcher tried to appeal to respondents to be considerate of him and accord him time for interviews as planned.

Information was also sought through an analysis of global policy debates and reading of policy documents. This information generally forms the basis of chapters 6 and 7. 


\subsection{Data analysis}

Following Critical Theory as a guiding analytical lens, data analysis took a macro perspective to research (see Bailey, 2007; Neuman, 2006). This meant looking beyond the micro issues as revealed through data to the larger historical and socio-political context of Malawi that influence anti-democratic practices within the university sector. Consequently, working from a Critical Theory stance, data were not viewed as meaningful in themselves since the interpretation of data from a Critical Theory perspective entails a self-reflexive analysis such as on how anti-democratic practices permeate the university sector in Malawi (see Krejsler, 2006; Marcuse, 1978; Willis, et al., 2007). Thoughtful analysis and reflection means that the researcher is involved in emancipatory knowledge production through self-reflexivity (see Cho \& Trent, 2006; Waghid, 2003). Accordingly, data analysis attempted to interrogate the nature of anti-democratic practices within the university sector in Malawi with two ideas in mind: the macro nature of analysis in Critical Theory and the generation of emancipatory knowledge through self-reflexivity by the researcher.

\subsubsection{In-depth interview data analysis}

While employing Critical Theory as a theoretical framework of the study, the study employed the Miles and Huberman Framework for Qualitative Data Analysis to analyse interview data (Miles \& Huberman, 1994; Punch, 1998, 2005). While the Miles and Huberman Framework for Qualitative Data Analysis is mostly used to make meaning of data that is based on unbiased research questions, in this research, the questions are biased in assuming that the university sector is generally anti-democratic. As such, the framework is not used to generate meaning from data as to whether university practices in Malawi are democratic or not, rather to aid in exposing the nature of antidemocratic practices within the university sector in Malawi. 
The researcher was mostly attracted to the intellectual activities of abstraction and comparison in meaning making as advanced by the framework. These intellectual activities, allowed the researcher to move from micro level issues to the macro perspectives such as neopatrimonialism and regionalism that impede democratic practices within the university sector in Malawi. Before explaining how this framework is employed in the thesis, an explanation of the framework follows.

The Miles and Huberman Framework for Qualitative Data Analysis is a framework that helps to organise qualitative data and make meaning out of the data through themes and proposition formation (Miles \& Huberman, 1994; Punch, 1998, 2005). This framework has three important stages: data reduction, data displays and drawing and verifying conclusions (Miles \& Huberman, 1994). Similarly it has three major activities: coding, memoing and developing conclusions (Miles \& Huberman, 1994; Punch, 2005). The whole data analysis process is however guided by two intellectual tools (employed by the researcher's intellectual capability): abstraction and comparison of data in order to arrive at research propositions (Punch, 2005).

Data reduction occurs continuously throughout the analysis (Miles \& Huberman, 1994). In early stages, it involves editing data, segmenting data and summarising ideas from the transcribed data (Miles \& Huberman, 1994; Punch, 1998, 2005). In the middle stages, it involves coding (labelling data) and memoing (theorising write ups of ideas) in order to find themes, clusters and patterns represented by the transcribed data (Miles \& Huberman, 1994; Punch, 1998, 2005). In the latter stages, it involves conceptualising and explaining.

Miles and Huberman (1994, p.13) suggest that: "data display refers to organised, compressed assembly of information that permits conclusion drawing and action". Data displays can be in the form of graphs, diagrams and 
many other forms that aid analysis. The last stage of the framework is drawing and verifying conclusions which are in form of propositions of the study and once they have been drawn they require verifying (Punch, 2005).

The intellectual activity of abstraction refers to the move from concrete terms to abstract levels in data analysis, while comparison refers to the comparing of different data indicators in order to move from concrete forms of data to abstract concepts that are behind the empirical data (Punch, 2005). In other words, it is by the intellectual activity of comparing that the intellectual activity of abstraction is possible so as to move to the one-upping (Punch, 2005).

This framework was used in analysing the interview transcriptions for this thesis. In-depth semi-structured interviews were firstly transcribed in order to employ the proposed framework for analysis. After transcriptions, data were reduced by editing the transcripts which involved checking spellings and listening to the interviews again to ascertain that what was transcribed was what the respondents really said. At this stage, data were segmented and summarised. For example responses of student union leaders were grouped together and similarly university leaders' responses were grouped together and so on. The next level of data reduction was coding the data manually in line with the research question that hinges on exploring the nature of antidemocratic practices within the university sector. The first level codes developed, helped to group anti-democratic practices within the university sector. The grouping of similar data revealed anti-democratic practices between university managers and academics, academics and students, academics and the university chancellor and so on. The grouped data formed the basis of theme formation later.

As data were coded, memos were developed by the researcher to record emerging patterns. For example, university staff union leaders identified 
problems that after coding were grouped under, strife between academics and university managers, as one of the problems faced at the universities. When it was ascertained that there were substantial responses from university staff union leaders attributed to strife between academics and university managers, the researcher wrote a memo (to himself within data analysis) about that, which read as follows: strife between academics and university managers seems to be an issue between academics and staff members.

When strife was reflected at all levels of interaction, the researcher then wrote another memo that read as follows: strife among actors within the university seems to be a cross cutting concern. The next step was to group the nature of strife among actors. Memos were useful in pointing to some pattern that the data were revealing in the process of analysis in order for the researcher to go beyond micro level issues.

Following Critical Theory analysis, when a similar pattern emerged across the data, it formed the basis of interrogating, for example, what the nature of strife reflected between leaders and their subjects revealed about the socio-political context of Malawi in order to expose the taken-for-granted aspects that permeated the university management. Relating data to the socio-political life of Malawi was helpful in order to understand a macro perspective or source of the anti-democratic practices that permeated the university sector and required emancipating.

The researcher displayed data by tabulating issues that were arising in two columns, one that explained the nature of the problem or issues and the other sources of the problem as exemplified: 


\begin{tabular}{|c|c|}
\hline Nature of problems/Issues & Source of the problems \\
\hline $\begin{array}{l}\text { - Bureaucratic managerial } \\
\text { practices } \\
\text { - Lack of communication within } \\
\text { the university }\end{array}$ & $\begin{array}{l}\text { Management, government, } \\
\text { university administration etc }\end{array}$ \\
\hline
\end{tabular}

Data displays were essential in taking research analysis further to understanding patterns that were forming in the research. From data reduction and data displays, the researcher used the intellectual tools of abstraction and comparison to draw conclusions and come up with research proposals which adhered to a macro analysis as required by Critical Theory and which attempted to answer the major research question of the thesis. For example, as noted, from descriptive data that constituted strife, the researcher saw a pattern that was evident within the leader-led relationship (see chapter 2) at the university level governance as well as at state-university relations.

Using intellectual tools of abstraction and comparison, the researcher employed self-reflexivity to deduce from the data that for example, regionalist and neopatrimonial aspects ingrained in Malawian society permeate university management and governance at micro levels complicating the leader-led relationship. Regionalist and neopatrimonial aspects then became macro contexts needing emancipation. As such, these aspects have been discussed in chapter 2 to aid understanding on how they permeate the management of the university sector. A brief explanation of data analysis from conceptual analysis and policy document analysis follows next. 


\subsubsection{Conceptual analysis and policy document analysis}

Conceptual analysis includes an examination of concepts or notions, terms and definitions with a view of examining them for clarity, coherence and understanding assumptions behind them (see Petocz \& Newbery, 2010). In this thesis conceptual analysis is employed for two reasons: first, to clarify concepts such as neopatrimonialism, policy, globalisation, neoliberalism and governance that are used within global university policy discourses. Further, to discern how these concepts are used within the global university policy discourses so as to expose the nature of anti-democratic practices that eventually affect the university sector in Malawi.

Conceptual analysis simultaneously led to a review of literature that generally augmented the account of the anti-democratic nature of policy-steerage by the international finance community as discussed in chapters 6 and 7. Thus, while chapters 8 to 11 analyse data from the respondents' perspectives, chapters 6 and 7 generally analyse global policy discourses from global policy debates and policy documents as they relate to the university sector in Malawi.

Reading policy documents from Malawi was aimed at examining whether documents reflected a need to address the anti-democratic practices within the university sector. Malawi Government policy documents read include: the Vision 2020, the Policy and Investment Framework, the National Education Sector Plan, the Malawi Growth and Development Strategy and university strategic plans. The next discussion hinges on issues of validity in Critical Theory research. 


\subsubsection{Ensuring validity of research}

Issues of reliability and validity in research generally depend on research paradigms used (Cho \& Trent, 2006). Thus, by adhering to Critical Theory this thesis articulates issues of reliability and validity differently from positivist or interpretive research approaches. Before explaining issues of reliability and validity as used in this thesis, a general brief explanation of the notions of reliability and validity is provided. The discussion shows two major developments: first, that notions of reliability and validity stem from positivist research and are adapted to qualitative research (Cho \& Trent, 2006; Golafshani, 2003; Thomas \& Magilvy, 2011; Whittemore, Chase, \& Mandle, 2001), and, second, that in qualitative research two major trends have emerged: the transactional and transformational validity (Cho \& Trent, 2006). Validity in this research adheres more to the latter approach.

As noted, notions of reliability and validity stem from positivist research. Reliability in positivist or quantitative research concerns the replicability of scientific findings whereas validity concerns the accuracy of findings (LeCompte \& Goetz, 1982). However, while reliability and validity of research are used in qualitative research, qualitative and quantitative research are based on different epistemological and ontological assumptions (see Cho \& Trent, 2006; LeCompte \& Goetz, 1982; Whittemore, et al., 2001). Consequently, the usage of terms reliability and validity carry different meanings in qualitative and quantitative research (Kirk \& Miller, 1986; LeCompte \& Goetz, 1982; Thomas \& Magilvy, 2011). Thus, without employing the replicability principle, reliability in qualitative research refers to the extent to which the set of meanings derived from several interpretations are adequately similar (LeCompte \& Goetz, 1982). Similarly, without necessarily aiming at the scientific accuracy of findings, validity in qualitative research addresses whether researchers see what they think they see (Kirk \& Miller, 1986), which depends on the value-laden nature of the qualitative research. 
While these understandings are traditionally accepted, Cho and Trent (2006) posit that in qualitative research, two major trends of validity have emerged: transactional and transformational validity. They note that transactional validity assumes that qualitative research can be more credible with usage of certain techniques, methods or strategies such as member checking, bracketing and triangulation (see Cho \& Trent, 2006; Willis, et al., 2007). Techniques such as member checking, bracketing and triangulation generally imply a positivist logic (Cho \& Trent, 2006). Associated with validity in this thesis, Cho and Trent contend that validity in Critical Theory research is transformative and they posit as follows:

Transformational validity is defined as a progressive, emancipatory
process leading toward social change that is to be achieved by the
research endeavour itself. Such a process in qualitative research, is a
critical element in changing the existing social condition of the
researched, involves a deeper, self-reflexive, empathetic understating
of the researcher while working with the researched (Cho \& Trent,
2006, p. 322).

As such, following Cho and Trent (2006), validity in Critical Theory is different from transactional approaches that assume that qualitative research can be more credible as long as certain techniques, methods or strategies are employed during the conduct of research. In this research, thus, validity entails a critical element in exposing the nature of anti-democratic practices within the university sector in Malawi and suggesting ways of emancipation or social change. Such validity is reflected through the researcher's self-reflexivity and empathetic understanding of the university stakeholders in Malawi requiring emancipation.

As such, validity in this research has been achieved through two ways: first, through the researcher's self-reflexivity to produce emancipatory knowledge by analysing both the micro and macro issues affecting the nature of antidemocratic practices within the university sector in Malawi. Further, through rigorous coding of the transcripts to come up with themes, patterns and conclusions using the Miles and Huberman Framework for Qualitative Data 
Analysis. The argument is that in this thesis validity is not so much something that can be achieved solely by way of certain techniques as advanced by mere interpretive research but by the research endeavour itself and through selfreflexivity and understanding of the researched who may be blinded by the taken-for-granted to chart their own emancipation (see Carr \& Kemmis, 1986; Cho \& Trent, 2006; Habermas, 1984, 1987).

\subsection{Ethical Issues}

Since qualitative research in social sciences focuses on examining people and their environment, it is embedded with power relations between researchers and respondents (Orb, Eisenhauer, \& Wynaden, 2000). Education research, thus, requires adherence to ethical issues (Bailey, 2007; Cohen, Manion, \& Morrison, 2007; Tomal, 2003). Adherence to ethical issues is intended to ensure that research respondents are not harmed during and after the research results (King \& Horrocks, 2010; Punch, 2005; Richards \& Schwartz, 2002).

Exploring the nature of anti-democratic practices within the university sector in Malawi was a sensitive activity that required thorough adherence to research ethics. As a consequence, prior to conducting the research, the researcher sought ethical approval from the Victoria University of Wellington Human Ethics Committee and conformed to the university's Human Ethics policy following the acceptance of the research proposal. In this thesis three risks and harm to be avoided were identified. These risks are anxiety and distress of respondents, misrepresentation of respondents' ideas and the identification of the respondents in published papers by themselves and others (see Richards \& Schwartz, 2002). 
Richards and Schwartz (2002) posit that the use of in-depth interviews can present anxiety and stress in respondents. Since this thesis employed indepth semi-structured interviews, some respondents were anxious and stressed for several reasons: first, as argued by Richards and Schwartz (2002), because of the probing nature of the interview, and, second, because as leaders, their own practices were implicitly being explored. To minimise these constraints or risks, the researcher ensured confidentiality of the research in that respondents were not named. As noted, prior to interviews, respondents were given a list of themes that the interview was going to cover in order to facilitate dialogue and minimise their stress.

The researcher sought informed consent after making sure that all respondents were provided with comprehensive details about the nature of the research and assured them that their participation was voluntary. Volunteers then confirmed their participation in the study by signing a written consent.

As noted, in this thesis, anxiety about misrepresenting respondents' ideas accurately was identified as a risk. During data collection, this was evident in the way some respondents repeatedly or continuously rephrased what they mentioned so as not to be misunderstood. More so, most respondents asked to listen to their recorded interviews perhaps to ascertain what they really said. Richard and Schwartz (2002) argue that the risk in misrepresenting respondents' ideas stems from theoretical stances of the researcher such that there is anxiety by respondents about how data shall be presented. Theoretical stances influence how information from research respondents is processed and how results get disseminated, and, thus, can bring fear among respondents who do not want their views to be misrepresented in the research findings (see Richards \& Schwartz, 2002). 
The danger of misrepresenting respondents' views has been reduced in this thesis through the use of self-reflexivity within the realms of transformational research and an adherence to careful and reflexive analysis using the Miles and Huberman Framework for qualitative Data Analysis.

While most studies minimise misrepresentation of respondents' views by member checking, or providing transcripts to respondents and discussing emerging research ideas (Cho \& Trent, 2006), since this thesis adheres to transformational research, minimising misrepresentation of respondents' views was tied to self-reflexivity of the researcher (Cho \& Trent, 2006). Using self-reflexivity meant that the researcher did not just explore the nature of anti-democratic practices within the university sector but went beyond to expose their sources that respondents may have not been aware of (the takenfor-granted). As such, there was no need for member checking or going through transcripts with respondents as the nature of research required the researcher to interrogate anti-democratic practices that were not readily understood by the respondents. Understating sources of anti-democratic practices at macro level enabled the researcher to suggest meaningful social change based on aspects that respondents mostly took for granted such as regionalism and neopatrimonialism discussed in chapter 2 .

The Miles and Huberman Framework for Qualitative Data Analysis allowed the researcher to arrive at themes, patterns and conclusions after coherent and rigorous coding of research transcriptions so as to avoid misrepresentation of respondents' ideas (see Miles \& Huberman, 1994). The framework enabled the researcher to use the intellectual activities of abstraction and comparison of data to understand macro sources of anti-democratic practices within the university sector in Malawi.

The third major risk that was identified in this thesis is the idea of respondents fearing to identify themselves or be identified by others in published papers. 
This concern was evidenced by some respondents who wanted clarification on how information they provided would be used and whether they would get results of the thesis as mentioned in the consent and information sheets. This fear was exacerbated by the quota system of university selection debate during the time of research, which revived tribal and regionalist debates in the country (see appendices $13 \& 14$ ) that have been sensitive since independence (Kaspin, 1995; Posner, 1995). Consequently, the research had to be guided by the principle of anonymity. As such, respondents' names were not mentioned in transcripts, although organisations, union groups, government ministries and institutions are named in the thesis. The implication here is that although individuals are not named the fact that their organisations are, in some cases this will lead to opinions being attributed to organisations or role holders. This was however, made clear to all the paticipants in a written consent and was disccussed before they voluntarily participated in the research. Further, the research discussions were kept confidential and respondents were given the right to withdraw from the research at any stage.

To maintain this confidentialility effectively, the researcher was the sole transcriber of the work and replaced names of respondents with codes in the transcripts. More so, printed transcripts were kept in a safe lockable facility. Respondents were told of the opportunity to check transcripts or excerpts if they wished. The researcher assured respondents that their views would only be used for the purposes of this PhD study, academic articles and conference papers without naming them. Given the nature of the purpose and usage of information required for this thesis, respondents were told that the interview transcripts would be kept for a maximum period of five years to assist in producing academic articles and conference papers as stipulated in the consent and information forms. Finally, to adhere to honesty, it was decided that the researcher would provide all respondents' with a written summary of the findings and a library link to the thesis. 


\subsection{Conclusion}

Chapter 5 has situated Critical Theory in qualitative inquiry. The argument presented is that by employing Critical Theory the researcher was able to expose the nature of anti-democratic practices and their sources within the university sector in Malawi and to produce emancipatory knowledge necessary for social change. Further, the chapter has explained the study population, data collection methods and analysis and ethical issues in this thesis. It is mentioned in this chapter that while chapters 8-11 present analyses based on respondents' views or data, chapters 6 and 7 are based on analyses of global policy debates and education policy documents. 


\section{CHAPTER 6}

\section{The World Bank and university education policy in Africa}

\subsection{Introduction}

This chapter uses policy debates to discuss anti-democratic practices in university education policy-steerage by the World Bank and its partner organisations in Africa including in Malawi. An assessment of global policy debates in this chapter reveals the World Bank's significant influence on policy initiatives, including university education in developing countries such as in Malawi (Brock-Utne, 2003; Malawi Government, 2009; Samoff \& Carrol, 2004a). Global policy discourses further show that the World Bank's policy initiatives for Africa follow a generalised pattern of policy prescriptions (Brock-Utne, 1996; Jones, 1998; Samoff \& Carrol, 2004b). Given the generalised pattern of policy prescriptions in which the World Bank operates, this chapter positions the Malawi case within a general African perspective. Ultimately, the chapter contributes to the thesis by showing the nature of antidemocratic practices in policy-steerage by the World Bank in Africa and in Malawi.

The chapter uses education policy debates to show how the World Bank has dominated education policy without giving much room to African governments to chart their own university education policies (Brock-Utne, 2003). The World Bank's domination on education policy in Africa, is considered as a kind of social control and anti-democratic (see Habermas, 1984, 1998). Using first generation Critical Theorists and Habermas, the argument presented in the chapter is that the policy influence exerted by the World Bank follows instrumental use of reason directed to achieve social control as part of the global-neoliberal-orthodoxy agenda. 
The instrumental use of reason by the World Bank is reflected by its role in advancing the global global-neoliberal-orthodoxy, which celebrates the market logic that negatively affects the African university sector (Jones, 1998; Olssen, Codd, \& O'Neill, 2004). Examples of instrumental use of reason by the World Bank are as follows: the World Bank's insistence on basic education at the expense of university education in Africa despite African governments' call for a sound higher education, the World Bank's legitimated control over African policy landscape through poverty discourses, the World Bank's use of power to instruct African countries to follow its specifications on the use of loans and in forcing its partner organisations to follow its decisions on education policy (Fraser, 2005; Robertson, et al., 2007; Samoff \& Carrol, 2004b).

The analysis of global policy debates in this chapter provides context to the discussion in chapter 10 that specifically examines evidence from respondents as to the influence of the World Bank on university education in Malawi. To situate the discussion on the World Bank's intervention in policy-making in Africa generally, the chapter starts by conceptual analyses of notions of policy, globalisation and neoliberalism, which are closely knit to the World Bank's policy-steerage discourse.

\subsection{Conceptualising policy}

The concept, policy, is elusive. However, to meaningfully engage with an analysis of the influence of the World Bank on university education policy in Malawi, it is essential to conceptualise the notion and sketch the different ways of thinking about policy-making. The enduring concepts in policy and policy processes hinge on power, authority and value allocation (Berkhout \& Wielemans, 1999). It is helpful to conceptualise (education) policy thus, in order to understand whose power, authority and values are being propelled, for example, by the World Bank in its university education policy-steerage in Malawi. A conceptual analysis of the notion policy and its related usage is 
helpful as it enables the thesis to explore the nature of anti-democratic practices by the World Bank, especially those that are usually not easily measurable as in positivist theorising.

The question is: what is policy? Or what should be regarded as policy that the World Bank uses to influence education policy in Malawi and Africa generally? Literature reveals distinct views about what policy is (Samoff \& Carrol, 2004a; Trowler, 1998). There are those who see policy as text or official statements, others who see it more of processes informed by particular discourses and yet others who view it as the "unsaid" that influence action or both the text and the unsaid that influence action (see Rizvi \& Lingard, 2010; Samoff \& Carrol, 2003, 2004a, 2004b; Trowler, 1998).

Education policy is often conceived as a thing or a statement within a policy document (Trowler, 1998). Education policy conceived this way, could be defined as a "specification of principles and actions, related to educational issues, which are followed or should be followed and which are designed to bring about desired goals" (Trowler, 1998, pp. 48-49). In this sense, policy is a text or a written statement to guide practice, which is a very limited view of what it means by policy (Trowler, 1998).

Another definition of policy is offered by Dye who contends that "public policy (such as education policy) is whatever governments choose to do or not to do" (Dye, 1987, p. 7). This definition implies that public policies involve choice on the part of governments to do something or to do nothing and fits well with Trowler's argument that seeing policy as text only is being narrow as choosing not to do something also constitutes policy. Dye's definition implies that the agent of public policy-making is the government. Thus, it can be argued that "although the activities of nongovernmental actors may and certainly do influence what governments do, the decisions or activities of such groups do not in themselves constitute public policy" (Howlett \& Ramesh, 1995, p. 5). 
Given that the World Bank works through governments (see Samoff \& Carrol, 2003, 2004a, 2004b), the World Bank influences what governments especially in Africa see as their own home grown policies, which may be presented in government policy texts such as the Malawi Growth and Development Strategy or simply constitute the unwritten policy, the kind of policy discourse that guides action.

Policies are revealed through texts, practices, symbols and discourses that explain and reflect power and value allocation (Birkland, 2005). In this thesis, what constitutes policy refers to what is written down but also that which guides action, "which may or may not be incorporated in a formal statement signed by officials"(Samoff \& Carrol, 2004a, p. 7). The stance followed in this thesis means that in terms of the World Bank's education policy influence, not all that guides the World Bank's actions towards countries such as Malawi are necessarily written down as policy-texts. The unwritten policy discourses also influence what governments such as Malawi choose to do or not to do in policy-making. Such a conceptualisation of policy is useful in this thesis as following on Critical Theory the thesis is interested in exploring antidemocratic practices such as those between the World Bank and the university sector some of which may be "hidden", or be the "taken-for-granted" (see Habermas, 1984) and difficult to quantify. Such a definition of policy enables the thesis to explore power relations in policy-steerage, which are not easily measurable.

\subsubsection{Policy-making processes}

Studies and discourses in policy-making have emerged from political scientists who aimed at helping governments to make rational ${ }^{4}$ policies

\footnotetext{
${ }^{4}$ Rational or rationalism meaning most efficient ways of achieving public policy and NOT as employed in a Habermasian sense .
} 
mostly shaped by the positivist paradigm (Rizvi \& Lingard, 2010). Positivist policy-making mechanisms have been employed by the World Bank in generalising policy prescriptions for Africa such as the Structural Adjustment Policies, Education for All Policy and university education user fees among others (see Banya \& Elu, 2001; Brock-Utne, 2003; Fraser, 2005; Robertson, et al., 2007; Samoff \& Carrol, 2004b; Tilak, 2005). As argued earlier, the danger of viewing policy largely in positivist ways is that policy-making ignores other ways of knowing especially those that cannot be quantified. More so, the functionalist tendency of positivism tends to influence instrumental rationality in policy-making aimed at control or manipulation of society (Waghid, 2003).

Rizvi and Lingard (2010) contend that working within positivist paradigm, political scientists developed several models to assist governments in policymaking. Although these models of policy-making are available to governments, perhaps the most common ones have been the rational and incremental models. Rational models "prescribe procedures for decision-making that will lead to the choice of the most efficient means of achieving public policy" (Howlett \& Ramesh, 1995, p. 140). Dye (1987) posits that rational model of policy-making involves the calculation of values and that policymakers ought to be aware of all the society's values in assessing policy choices. As can be imagined, calculating values is not easy and would generally follow the positivist logic.

The incremental model views public policy as "a continuum of past government activities with only incremental modifications" (Dye, 1987, p. 36). The danger of conceiving policy incrementally is that creativity in policymaking is suppressed as policies tend to follow rigid government prescriptions (see Shawa, 2007), which may be already influenced by powerful institutions such as the World Bank. In general, these policy models do not give much room to critical analyses which may be more appropriate in understanding how power, authority and values may be steered by for example, the World 
Bank in its university policy-steerage in a country like Malawi. The next discussion conceptualises the notion, globalisation.

\subsection{Conceptualising globalisation}

Globalisation is a difficult term to define. However, it is generally accepted that it consists of the alteration of space and time in terms of culture, politics and economics that extends beyond nation-states (Rust \& Jacob, 2005). This perspective of globalisation implies that global changes have implications for nation-states such as Malawi in policy-steerage. To understand the effects of globalisation on university education in Malawi, it is helpful to engage with the notion as the World Bank employs global mechanisms in its policy-steerage (Jones, 1998; Olssen, et al., 2004; Samoff \& Carrol, 2004a).

There are three broad strands of globalisation: the economic, cultural and the political (Allen, 1995). In terms of economic globalisation, Allen (1995) sees the world economy functioning beyond nation-states, which means that economic conceptions such as those propelled by the World Bank quickly affect nation-states globally. In terms of cultural globalisation, Allen (1995) sees the promotion of the western forms of ways of life engulfing the world and in terms of political globalisation; he sees challenges concerning the role and power of nation-states. Globalisation can also be viewed as an ideology (a system of widely shared beliefs, guiding norms and values, and ideals accepted as truth by a group of people) (Rizvi \& Lingard, 2010). Viewed in this way, it "represents a range of loosely connected ideas designed to describe new forms of political-economic governance based on the extension of market relationships globally" (Rizvi \& Lingard, 2010, p. 31). It is argued thus, that at the centre of globalisation is strong adherence to market forces. 
Globalisation and its market forces threaten democratic institutions and impedes development in Africa (Geo-Jaja \& Zadja, 2005). Africa has so far experienced four stages of continental oppression: first, slavery; second, colonialism, third, neoliberalism and fourth, a new global economic order which affects university education policy-steerage (Geo-Jaja \& Zadja, 2005). It is argued that economic globalisation is global capitalism, which keeps Africa in a dependency loop (see Potter, Binns, Elliot, \& Smith, 2008). It is within this globalised market logic that the World Bank and partner organisations work in their policy initiatives including those for university education (see BrockUtne, 1996, 2003; Fraser, 2005; Samoff \& Carrol, 2003, 2004a, 2004b). As noted, the power that derives from such market logic to restructure the university sector in Africa reflects manipulative mechanisms or instrumental use of reason by the World Bank and its partner organisations. The next discussion briefly conceptualises the notion, neoliberalism, to aid understanding of the effects of market forces on university education in Africa.

\subsection{Conceptualising neoliberalism}

To understand the influence of the global-neoliberal-orthodoxy within which the World Bank works there is a need to engage with the notion neoliberalism. The term neoliberalism is an extension of the concept liberalism (Olssen, et al., 2004). Liberalism advances free market mechanisms and is opposed to government interference in the economy (Potter, et al., 2008). With the rise of the new right in the 1980s, during the reign of Margaret Thatcher and Ronald Reagan in the United Kingdom and the United States respectively, there emerged new stress on economic liberalism as opposed to Keynesian economics (Potter, et al., 2008). Whereas the new right is essentially different from neoliberalism, the two terms are closely related and are mostly used interchangeably (Olssen, et al., 2004). It is during this period that the term and ideology neoliberalism took shape as a new way of looking at liberalism 
(Potter, et al., 2008; Robertson, et al., 2007; Samoff \& Carrol, 2003, 2004a, 2004b).

However, it is important to note that while classical liberalism viewed state power negatively and as impeding individual freedom, neoliberalism views the state power positively in facilitating for market mechanisms (Olssen, et al., 2004). In general, the neoliberal agenda celebrates strong market driven policies, against the central role of states in national economic development such as those advanced by Keynesian economics (Potter, et al., 2008; Robertson, et al., 2007; Samoff \& Carrol, 2003, 2004a, 2004b).

Neoliberalism is viewed as an aspect of globalisation in that it shapes the local and global economic spaces such as the education policy landscape (Olssen \& Peters, 2005). It is argued in this thesis that the influence of the World Bank on university education policy follows the global-neoliberal-orthodoxy. The next section discusses the World Bank's involvement in education policy in Africa in order to show the nature of anti-democratic practices rested on power relations between the powerful World Bank and African countries within the global-neoliberal-orthodoxy.

\subsection{The World Bank's involvement in education policy in Africa}

Given the forces of the global-neoliberal-orthodoxy mentioned earlier, the world can be viewed as responding to and working within a global-neoliberal system (see Samoff \& Carrol, 2004a). The argument presented here is that within the global-neoliberal-orthodoxy, "today, the World Bank has become one of the major managers of the world system, including the integration of African countries into an economic order largely defined and governed outside the continent" (Samoff \& Carrol, 2004a, p. 56). To explore anti-democratic practices within university education policy-steerage in Malawi, thus, demands 
an understanding of how the World Bank operates within the globalneoliberal-orthodoxy or in managing the world system. However, this is not an easy task as the influence has become subtle and not easy to pinpoint (see Peters, 2003a; Peters, 2003b; Peters \& Besley, 2004). In general terms though, the global-neoliberal-orthodoxy seems to perpetuate a dependency syndrome especially on the part of African governments (Geo-Jaja \& Zadja, 2005). This dependence syndrome perpetuates instrumental use of reason by the World Bank in its university education policy-steerage in Africa aimed at social control.

Although most post-colonial African universities began with dependence, as they were opened by the help of colonial masters who assisted to form links between European universities and African universities (Ajayi, Goma, \& Johnson, 1996), this dependency has taken different forms today as more actors such as the World Bank have come in. Created in 1944 as an International Bank for Reconstruction and Development, the World Bank did not intend to get involved in education policy as it was interested only in productive activities (Samoff \& Carrol, 2003, 2004a, 2004b). It was not surprising then that the World Bank rejected an application from the United Nations Educational, Scientific and Cultural Organisation to fund schools and university education in the underdeveloped world in 1957 (Robertson, et al., 2007). However, using the human capital theory which proposes that education be seen as investment and key tenet of economic growth (Olssen, et al., 2004), the World Bank started to support education in Africa as an investment or a form of human capital (Bloom, et al., 2006; Bloom \& Rosovsky, 2007; Robertson, et al., 2007; Samoff \& Carrol, 2004a). The next discussion starts highlighting the early period of the World Bank's involvement in African university education to aid more understanding of the World Bank's influence on African education policy. 


\subsubsection{African developmental university and manpower planning}

The discussion in this section, backgrounds the World Bank's involvement in African university education. The discussion helps in understanding the antidemocratic or instrumental ways in which the World Bank operates in its university education policy-steerage in Africa generally and in Malawi in particular. By the 1950s the notion of an African developmental university emerged, which facilitated support for the university sector from multilateral firms and agencies such as the World Bank (Samoff \& Carrol, 2003). As noted, guided by the human capital theory, the World Bank responded to the notion of a developmental university by supporting African university education as an investment. The World Bank thus started granting university education loans to African countries and urged them to view university education as and investment and prioritise manpower planning to replace the departing colonial personnel (Samoff \& Carrol, 2003, 2004a, 2004b).

However, the notion of an African developmental university that was used to attract funding to the university sector in Africa suffered after the World Bank started to follow economists who advanced the rate of return analysis. The rate of return analysis assesses the public and private costs of education and their benefits (Robertson, et al., 2007). Economists who adhered to the rate of return analysis proposed more investment in basic rather than in university education in Africa (Bloom, et al., 2006; Bloom \& Rosovsky, 2007). Using this analysis, the World Bank argued that basic education was more likely to contribute to poverty alleviation than the university sector in Africa (Bloom, et al., 2006; Bloom \& Rosovsky, 2007; Brock-Utne, 2003; Robertson, et al., 2007). Given the World Bank's view, investment in university education was not encouraged and the World Bank prioritised restructuring of the university sector generally (Bloom, et al., 2006; Robertson, et al., 2007; Samoff \& Carrol, 2004b). For example, while the World Bank spent $17 \%$ of its worldwide education support on higher education for the period 1985-1989 this reduced to $7 \%$ for the period 1995-1999 (Bloom, et al., 2006). 
Drawing on the rate of return analysis, higher education in Africa was viewed as costly and unproductive public service that only benefitted the rich (Bloom, et al., 2006). Working within this logic, it was not surprising that the World Bank and its partner organisations directed resources to the basic education sector in Africa (Samoff \& Carrol, 2004b). African university education such as in Malawi suffered and had no choice but to succumb to the thinking of the World Bank in supporting the basic education sector at the expense of university education. The Malawi Government had no choice as the World Bank decided to direct its funds to the basic education sector (Brock-Utne, 2003). The argument presented here is that the way the World Bank dominates education policy reflects instrumental use of reason. The basic education priority is discussed next.

\subsubsection{The basic education priority}

The argument presented here is that using the rate of return analysis mentioned earlier, the stress on basic education was forced on African governments such as Malawi and was at the expense of the development of the African university sector and of secondary education (Brock-Utne, 1996, 2003; Samoff \& Carrol, 2003, 2004a, 2004b). The World Bank shifted its resources to basic education and advised its partner organisations to follow suit (BrockUtne, 2003). The powerful World Bank gave no choice to African countries to chart their own education policy priorities. This led to the stagnation of higher education in Africa. Since African governments were compelled to follow the thinking of the World Bank which had money to disburse as loans (see BrockUtne, 1996, 2003), the stress on basic education at the expense of university education, can be said to be an example of instrumental rationality meant to control and perpetuate the World Bank's global-neoliberal priorities. The 1990 Education for All Conference in Jomtien, Thailand is viewed as having been used to justify the restructuring of the African university education sector by the World Bank (Brock-Utne, 1996, 2003; Samoff \& Carrol, 2003, 2004a, $2004 \mathrm{~b}$ ). Using the rate of rate of return analysis, the World Bank went on to 
criticise African universities as expensive and inappropriate despite calls for support of the sector by African governments (Brock-Utne, 1996, 2003).

The Education Policies for sub-Saharan Africa policy document by the World Bank in 1988, proposed reduction of university funding levels in Africa and argued that African university education was a luxury (Brock-Utne, 1996, 2003). Championing the global-neoliberal agenda, the World Bank argued that university education in Africa should mostly produce skills required by the market (Brock-Utne, 1996, 2003). The World Bank saw itself as mandated to make policies for Africa that follow its global-neoliberal logic. In this way, the activities of the World Bank can be said to be anti-democratic regarding university policy-steerage in Africa as it does not provide space for African governments to devise their policy priorities for the university sector. The World Bank is too powerful such that it steers its education policy dogmatically (see Habermas, 1984, 1987, 1998). In Habermasian sense, the World Bank has colonising power that requires rationalising if African policymakers are to chart their own university education priorities (Habermas, 1987). Next, follows a brief discussion of Structural Adjustment Policies that further exemplify how the World Bank used positivist views to generalise policy prescriptions for Africa, which eventually affected the African university sector generally.

\subsection{Structural Adjustment Policies and education in Africa}

The Structural Adjustment Policies are discussed within the policy rationale that emerged between 1980-1990 mostly referred to as the Washington Consensus in which the neo-liberal agenda took primacy (Robertson, et al., 2007). The term Washington consensus was coined by Williamson in 1989 (Williamson, 2004). The key points of the Structural Adjustment Policy include: the devaluation and unification of the exchange rate and the elimination of exchange controls, curtailment of expenditure to alleviate 
budget deficits, cuts in public wage bills and social sector programmes, market liberalisation within the national economies, the elimination of subsidies and price controls, compression of real earnings and the liberalisation of the labour market (Ibhawoh, 1999). With the Structural Adjustment Policy lending in the 1980, 24 African countries accepted the debts and by 1993 the programme was being implemented in 36 African countries including Malawi (Ibhawoh, 1999).

The argument presented here is that Structural Adjustment Policies were quick fix measures that affected the university sector in Africa due to reallocation of resources to basic education, the introduction of fees in the university sector and which brought about strife in African universities such as in Malawi (see Adedeji, 1999; Brock-Utne, 1996, 2003; Samoff \& Carrol, 2003, 2004a, 2004b; Zeilig, 2009; Zeilig \& Dawson, 2008).

The spread of the global-neoliberal agenda of the Structural Adjustment Policies followed the 1980-1982 worldwide economic recession and was mostly facilitated by the failure of Mexico to pay its debt in 1982 (Ibhawoh, 1999). For Africa, Structural Adjustment Policies started as quick fix, one sizefits all measures without a clear understanding of development priorities of the continent (Adedeji, 1999). Given the general world recession, most African countries turned to borrowing to sustain their economies (Ibhawoh, 1999). As a result, the World Bank and the International Monetary Fund increased the level of conditions required for loans and credits to developing countries (Ibhawoh, 1999). Given the situation, the World Bank and the International Monetary Fund found an opportunity to extend their grip on African countries. In this way the World Bank maintained its power over university policysteerage in Africa generally.

During the period of Structural Adjustment Policies lending the education sector just as other social sectors suffered in most developing countries 
(Samoff \& Carrol, 2004b). Since during this time the World Bank insisted on the human capital theory and the rate of return analysis alluded to earlier, it preferred basic education to university education and general privatising of social services to government control (Robertson, et al., 2007). Brock-Utne's (1996) example of the 1988 World Bank loan for primary school sector given to Malawi on condition that the University of Malawi cut book allowances as well as all funding for student vacations even though the university had not asked for a loan, serves here as a case in point.

Structural Adjustment Policies affected students and the general running of universities in Africa (Zeilig \& Dawson, 2008). While following independence in Africa, "university students were part of a privileged and transitory social group, waiting to be allocated graduate employment in an expanding civil service and across the state-sector" (Zeilig \& Dawson, 2008, p. 2), with Structural Adjustment Policies, the university sector was starved resulting in serious riots in most African universities such as in Malawi. In general terms, the effects of Structural Adjustment Policies have been well summarised by Ibhawoh (1999) who contends that:

Liberalisation of labour markets has left millions of breadwinners unemployed, while the introduction of fees in the delivery of previously free social services, including health and education, has raised the cost of living. In a situation, as in most African countries, where there are no reliable social welfare systems, millions more of dependents become destitute or economic refugees in the already overcrowded urban centres. Mass retrenchments in the public sector swell the rank of unemployed, creating discontent, a restive population and pervasive social tension... (Ibhawoh, 1999, p. 160).

It is argued that since the World Bank and the International Monetary Fund found great opportunity to exert more control over Africa such as by formulating university policies for the continent at this time, their policies reflect instrumental use of reason meant to manipulate and control. Following on from Horkheimer and other critical Theorists, this is an example of instrumental reasoning in which the powerful dominate and control society for their own gains and as such the very reason that is meant to inform 
critique and lead to emancipation succumbs to unreason or to oppression (see Rasmussen, 1996).

By the late 1980s, the neoliberal approach reflected by the Washington Consensus was generally criticised for impeding development in Africa (Robertson, et al., 2007; Samoff \& Carrol, 2003, 2004a, 2004b). The Structural Adjustment Policies were considered as only focussed on debt repayments rather than on reducing poverty and inequality in Africa (Robertson, et al., 2007). These critiques led to the Post-Washington Consensus which was meant to include the "social" that was missing from the Structural Adjustment Policies (Fraser, 2005; Robertson, et al., 2007; Stewart \& Wang, 2003). However, it is debatable whether there has been substantial move away from the global-neoliberal-orthodoxy agenda as the next discussion shall show.

\subsection{The Post-Washington Consensus}

The argument presented in this discussion is that the Post-Washington Consensus which was meant to bring the idea of the social in global policy initiatives, has simply legitimised the control of the World Bank in developing countries such as Malawi and that as such, university policy-steerage by the World Bank shall continue to be framed within the global-neoliberalorthodoxy, which follows instrumental reasoning. By the late 1990s, the neoliberal ideas of the Washington Consensus were generally viewed as limited (Potter, et al., 2008; Robertson, et al., 2007). Just as Thatcher and Reagan propelled the Washington Consensus, Clinton and Blair in the mid 1990s in the United States and the United Kingdom respectively, propelled a shift toward the Post-Washington Consensus that was meant to bring the social in its policies (Robertson, et al., 2007). This led to the preference of the Poverty Reduction Strategy Papers to the Structural Adjustment Policies by the international financial community (Fraser, 2005). 
Poverty Reduction Strategy Papers were intended to prevent the World Bank and the International Monetary Fund from imposing policies as they were planned to be written by individual countries to prioritise their developmental requirements tapping on their social capital (Fraser, 2005). African countries were asked to produce a Poverty Reduction Strategy Paper with guidelines from the World Bank (Stewart \& Wang, 2003). The fact that guidelines came from the World Bank suggest problems within policy-steerage.

The Poverty Reduction Strategy Papers were a condition for getting more loans (Fraser, 2005). They were generally "policy documents produced by borrower countries outlining the economic, social and structural programmes to reduce poverty, to be implemented over three years"(Stewart \& Wang, 2003, p. 4). Following the Post-Washington Consensus, education policy has been entangled within development discourses generally and especially poverty reduction mechanisms (Samoff \& Carrol, 2003, 2004a, 2004b). Employing the idea of social capital, the Post-Washington Consensus supported participatory development mechanisms in Africa for economic growth as opposed to Structural Adjustment Policies (Fraser, 2005; Robertson, et al., 2007; Stewart \& Wang, 2003). Consequently, in African countries such as in Malawi, the idea of social capital was employed in the preparation of Poverty Reduction Strategy Papers in 1999 that replaced Structural Adjustment Policies (Robertson, et al., 2007; Stewart \& Wang, 2003).

Since Poverty Reduction Strategy Papers were meant to be country driven, the World Bank and the International Monetary Fund, argued that they would encourage a sense of national prioritisation of policies (Robertson, et al., 2007). However, although the World Bank hoped to achieve a sense of national prioritisation of policies through the Poverty Reduction Strategy Papers, the priorities of Poverty Reduction Strategy Papers in most African countries are very comparable to Structural Adjustment Policies, which suggest limited policy change (Stewart \& Wang, 2003). This reveals the influence of the World Bank on what varied national groups formulating Poverty Reduction Strategy 
Papers in Africa viewed as their national development policy priorities. It is important to note that the World Bank's influence is both direct and indirect (Samoff \& Carrol, 2004a).

The Poverty Reduction Strategy Paper processes have mostly just legitimised the influence of the World Bank (Fraser 2005). Although individual African countries have now developed other country papers such as the Malawi Growth and Development Strategy stemming from the Poverty Reduction Strategy Papers, the Poverty Reduction Strategy Paper rationale still forms the basis for policy in Africa (Stewart \& Wang, 2003). The legitimating of influence on the African policy landscape presents domination and instrumental use of reason by the World Bank. The anti-democratic policy-steerage by the World Bank is well captured by Sammoff and Carrol (2004) in their discussion of the Poverty Reduction Strategy Papers' country participatory processes as follows:

...many more people can sit in the driver's seat. They may determine its
speed and fuel economy. The national government and community
organisations are responsible for what happens. But they are
proceeding along tracks whose directions and technical specifications
have been set elsewhere (Samoff \& Carrol, 2004a, p. 46).

These sentiments expressed by Sammoff and Carol (2004) are central in understanding anti-democratic policy-steerage by the World Bank and in assessing what most African countries term home grown policies such as the Malawi Growth and Development Strategy. All in all Poverty Reduction Strategy Papers can be "understood as a technology of social control which seek to shape the domestic political space" (Fraser, 2005, p. 317). It is this domination that is viewed as anti-democratic in this thesis as it limits the power of individual African countries to propel their own policies such as in the university sector. 


\subsection{The Knowledge economy}

The knowledge economy is an elusive phrase (Peters \& Besley, 2004; Powell \& Snellman, 2004). It can be defined as "production and services based on knowledge-intensive activities that contribute to an accelerated pace of technological and scientific advance as well as equally rapid obsolescence" (Powell \& Snellman, 2004, p. 201). The knowledge economy means productivity that stems from the use of the human intellect as opposed to those based on natural resources (Peters, 2003b; Powell \& Snellman, 2004). It is thus, about innovation and intellectual prowess. Given stress on intellectual innovation for production or economic progress, the knowledge economy discourse is necessarily linked to university education (Peters, 2003a, 2003b; Peters \& Besley, 2004).

The World Bank has thus since the late 1990s shown keen interest in the knowledge economy discourse and African university education (Olssen \& Peters, 2005; Peters \& Besley, 2004; Samoff \& Carrol, 2004a). The World Bank's contention is that aligning university education to the knowledge economy has the potential for alleviating poverty in Africa (Bloom, et al., 2006; Bloom \& Rosovsky, 2007; Samoff \& Carrol, 2003, 2004a, 2004b). Brock-Utne (2003) reminds us that this was the same mandate that was given to basic education at the Jomtien Conference.

The World Bank proposes that sub-Saharan African countries ought to raise the quality of university education through linking their education to the labour market, improving equitable access and providing differentiation in programmes offered (Ng'ethe, et al., 2008; World Bank, 2009). By insisting on linking university education to the labour market, the World Bank is perpetuating a view of university education that undermines areas of study that develop critical abilities that may be useful in developing Africa (Beckmann \& Cooper, 2004). 
While adhering to the knowledge economy has its benefits, here is yet another opportunity for the World Bank to perpetuate its control over African education by formulating policies for African university education. For example, by insisting on aligning university education to the labour market, the World Bank advances a market conception of university education. As noted, a market conception of education has the potential to hinder critical analysis required by citizens to advance democracy and citizenship values pertinent to Africa (Giroux, 2003).

As argued earlier, given that policy in viewed to encompass discourses and all that guides actions, it is expected that the influence of the World Bank's policies shall, within the global realm of thought, creep into university policy restructuring in countries such as Malawi with ease. This is because the World Bank is powerful and has legitimated its power in Africa. The last discussion in this chapter highlights how the World Bank influences (education) policy in Africa generally.

\subsection{The World Bank's influence on [education] policy}

The contention presented here is that the World Bank managed to legitimise its influence in Malawi and Africa directly and indirectly such that it has become very difficult for developing countries to propel their own policy agenda including that of university education without largely following the World Bank's specifications. This has created dependence that reifies the World Bank as powerful. This usage of power is viewed in this thesis as representing a force of coercion and follows instrumental rationality (Habermas, 1984). 
Samoff and Carrol (2004) have isolated different ways in which the World Bank manages this influence as part of its management of a world system mentioned earlier. In terms of direct influence, they argue that first, "the World Bank instructs loan recipients on what they should and should not do, when and how" (Samoff \& Carrol, 2003, p. 43). This means that loan recipient countries such as Malawi cannot prioritise their own agenda. In making countries fail to priorities their own agenda, the World Bank steers policy from the point of power, which in a Habermasian sense is dominating and represents a force of coercion (Habermas, 1984). As such, the World Bank uses its lending ability to exert direct influence on Africa. Second, the World Bank exerts control through its wide publication which legitimises its intentions (Samoff \& Carrol, 2003). This means that it is easy for the World Bank to reach out to intended audiences and propel its stances. In this way the World Bank has positioned itself as an authority on policy in Africa including that of education. Having positioned itself as authoritative, the World Bank easily controls the policy arena in Africa. Third, the World Bank exerts its control by endorsing which African countries are following its policy prescriptions such that where prescriptions seem not to be adhered to all funding is halted (Samoff \& Carrol, 2004a). This reveals the vulnerability of African countries such as Malawi at the hand of the powerful World Bank.

All in all, policy debates or discourses reveal the domination of the World Bank in its policy-steerage including that of university education in Africa. Within Critical Theory as employed in this thesis, the domination of the World Bank shows a lack of dialectical reasoning and communicative rationality on the part of the World Bank's leadership. The dominating tendencies are thus regarded as anti-democratic and requiring change. These views shall be augmented by interview data in chapter 10 that present specific accounts of the influence of the World Bank on university education in Malawi. 


\subsection{Conclusion}

This chapter has advanced the argument that the World Bank dominates education policy in Africa generally and especially in Malawi. This domination reflects instrumental use of reason meant to control within the globalneoliberal logic. The chapter has augmented these claims by showing that for example, using the human capital theory and the rate of return analysis, the World Bank supported basic education at the expense of university education despite calls by the African governments for support of the university sector. Second, using Structural Adjustment Policies the World Bank supported cuts from higher education within the neoliberal logic; third, using the PostWashington Consensus the World Bank has legitimised its control over African policy generally, which facilitates market mechanisms in policy-steerage and fourth, using the knowledge economy idea the World Bank has intensified its plan of aligning university education to the labour market in Africa, thus repositioned its power in formulating policies for the African university sector. In general, the World Bank influences education policy both directly and indirectly. The chapter, thus, reveals that the World Bank propels its university policy through the global-neoliberal-orthodoxy within the powerful lesspowerful logic regarded from Critical Theory perspective in this thesis as lacking dialectical reasoning and communicative rationality. 


\section{CHAPTER 7}

\section{Global changes in university governance and its impact on Malawi}

\subsection{Introduction}

This chapter discusses changes in global university governance, which follow the global-neoliberal-orthodoxy (Hall, 2005; Olssen \& Peters, 2005) and their projected impact on university governance in Malawi. As noted, the global in relation to university policy steerage, is viewed in this thesis as antidemocratic (Peters, 2004). The chapter contributes to the thesis by showing that African governments including in Malawi, have begun to respond to the global-neoliberal-orthodoxy in their university governance and policysteerage hence moving toward anti-democratic modes of governance. Simultaneously, the chapter highlights the interventionist characteristics of university governance structures in Malawi whose further implications shall be discussed in chapter 9 .

In most countries, the intellectual oriented university that facilitates free deliberative and collegial governance is being replaced by the neoliberal associated form of governance, the new-managerialism (Davies, Gottsche, \& Bansel, 2006; Hall, 2005). New-managerialism adheres to a need for quality assurance, performativity, audit cultures, strategic planning and general assessment tools (Olssen \& Peters, 2005). The regulatory mechanisms mentioned above follow the dictates of the knowledge economy discussed in chapter 6 which convey a need to align university education to the needs of industry (Olssen \& Peters, 2005). Such a conception of the university obscures efforts for collegial or democratic governance and citizenship education (see Beckmann \& Cooper, 2004; Davies, et al., 2006; Delanty, 2003; Olsen \& Peters, 2005) as universities run like industry. More so, the new-managerialism 
encourages universities to concentrate on producing skills required by the labour market at the expense of critical reflections required to build democratic societies (Giroux, 2003).

Recent legal frameworks in sub-Saharan African universities reflect trends associated with the new-managerialism (Saint, 2009). For example, Policy documents in Malawi such as the Policy and Investment Framework and the National Education Sector Plan call for university governance characterised by a need for quality assurance mechanisms, policy guidance and accountability systems (see Hayward \& Ncayiyana, 2006; Malawi Government, 2000a, 2006b). Since in Africa these mechanisms are generally steered by the World Bank, which has legitimised its authority as argued in chapter 6, they will easily be incorporated into the African university education (see Samoff \& Carrol, 2004b). Thus, although, the Malawi university sector is just starting to respond to these mechanisms, there is a need to engage with problems that stem from neoliberalism and associated governance discourses of the newmanagerialism. The chapter starts by discussing evidence of gradual changes toward the new-managerialism in Malawi.

\subsection{Evidence of changes toward the new-managerialism in Malawi}

In revising legal frameworks, sub-Saharan African governments tend to follow international trends such as those propelled by the World Bank (Saint, 2009). As such, African universities, have embarked on restructuring university governance to reflect the demands of the global-neoliberal-orthodoxy and the knowledge economy such as in expanding institutional autonomy, introducing a performative culture and aligning universities with the labour market (Saint, 2009). To achieve these changes, most African governments have established councils for higher education to oversee their education systems (Saint, 2009). 
Similarly, the Malawi Government and the university sector have proposed a Malawi Council for Higher Education following a report on higher education policy assessment (Hayward \& Ncayiyana, 2006). The proposed Malawi Council for Higher Education was to be empowered to facilitate coordination of public universities, approve the registration of new institutions, recommend quality assurance mechanisms, review university governance and strengthen transparency and accountability mechanisms (Hayward \& Ncayiyana, 2006; Malawi Government, 2006b). The new trends in Malawi reflect a sense of corporatism (Malawi Government, 2000a). For example, the Policy and Investment Framework proposes the following policy directions for higher education financing in Malawi: that tertiary institutions are required to promote cost-effective use of available resources, devise strategies to enhance their capacity to diversify their revenue sources and to introduce appropriate cost sharing mechanisms aimed at reducing government's subvention for higher education (Malawi Government, 2000a). Taken together, these policy propositions reflect a gradual move toward the new-managerialism in Malawi. The next section situates the Malawi scenario in general global university policy-steerage mechanisms.

\subsection{Global policy-steerage and university governance in Malawi}

There are three major state university policy-steerage mechanisms: state control, state supervision and the market (Taylor \& Miroiu, 2002). For the purposes of this thesis, the first two are discussed. University policy-steerage mechanisms impact on institutional governance in several ways (Gornitzka, 1999; Taylor \& Miroiu, 2002). For example, state policy-steerage models can affect a range of governance issues within the university such as: finance management, flexibility to conclude university contracts, curriculum development and many other educational matters (Taylor \& Miroiu, 2002). This section starts by discussing the state-control university policy- steerage model as reflected in university governance in Malawi. 


\subsubsection{The state-control model and university governance in Malawi}

An assessment of the state-control university policy-steerage model, contributes to an understanding of the nature of anti-democratic practices within the university sector in Malawi. While the state-control model developed into negative control of universities in many African countries such as in Malawi (Habib, et al., 2008; Kerr \& Mapanje, 2002; Sherman, 1990; Sturges, 1998), the model ought not to be necessarily negative.

The state-control university policy-steerage model adheres to strict government control and has historically characterised the higher education sector (Gornitzka, 1999; Moja, Muller, \& Cloete, 1996; Taylor \& Miroiu, 2002). With this model, university education is directly managed by governments, and universities are part of the general public administration (Van Vught, 1994). This model is characterised by strong dependency on government funding and decisions (Gornitzka, 1999). The model is useful in terms of achieving university education that contributes to national growth, a view which has been advanced by African leaders generally (Moja, et al., 1996).

Studies on African university management and governance (see Gaidzanwa, 1994; Saint, 2009) show the following key features of the state-control university policy-steerage model: the dominance of the government of the day through the Ministry of Education; a system of university council, senate and a university administration headed by a vice-chancellor with deans heading faculties; use of acts of parliaments and availability of university councils that are mandated with managing the universities. These features characterise universities in Malawi (see Mzuzu University, 1997; The University of Malawi, 1998).

This model is sometimes confused within the interventionist university control (Moja, et al., 1996). However, the likening of the state-control to the interventionist model is a little confusing and rather problematic as the latter 
is "not a systematic policy control model, rather intervention occurs when higher education institutions become sites of opposition to the development path or perceived political direction of the state" (Moja, et al., 1996, p. 148). The interventionist control of university policy-steerage has the following features: an inactive chancellor who is often also the president of the country; a weak Ministry of Education which fails to promote universities; a weak and poorly educated personnel in the higher university planning department; university councils which are largely dormant and only reactive to issues; large senates that solely concentrate on academic issues and vice-chancellors who are normally appointed and fired at the pleasure of the state presidents (Omari, 1991).

While the features of the state-control mechanism, as described earlier, help to explain the Malawi Government's policy-steerage structure, the characteristics of the interventionist university policy-steerage control offered by Omari (1991) largely typify the university governance sector in Malawi. It is important to note that anti-democratic practices in policy-steerage in Malawi are embedded within this interventionist control mechanism as shall be argued in chapter 9. Combined with the interventionist mode of policysteerage in Malawi, is the emerging new-managerialism mentioned earlier. The next discussion explains the state-supervisory model mostly linked to the new-managerialism (Taylor \& Miroiu, 2002).

\subsubsection{The state-supervisory model and university governance in Malawi}

The state-supervisory university policy-steerage model is different from the state-control as it allows more freedom to universities to decide their goals and stresses institutional autonomy (Gornitzka, 1999; Taylor \& Miroiu, 2002). Taylor and Miroiu (2002) argue that this model, also called the newmanagerialism, is oriented to the market and that most European countries are moving toward it. The following characterise the state-supervisory model of university policy-steerage: withdrawal of governments from control 
functions; formation of buffer bodies such as councils for higher education; developing funding models that give flexibility to institutions to diversify sources of income; formation of quality assurance and accountability systems, affirmation of the university governing board as accountable to the minster or buffer body, and gradual withdrawal of the state from direct decision-making on the appointment of the university council chairpersons (Fielden, 2008; Saint, 2009).

As noted, while African university education is chiefly characterised by the state-control model, newer legal frameworks for university education reflect international trends of the state-supervisory model. As argued earlier, in Malawi, education policy documents refer to some of these changes (Malawi Government, 2000a, 2006b). This discussion has generally augmented the idea that governance structures in Africa and in Malawi are being influenced by global trends. The next discussion concentrate on the effects of changes in state-steerage models on the nature of institutional governance.

\subsection{The nature of university governance in Malawi}

The nature of state university policy-steerage influences whether university governance systems in a country follow the republic of scholars' (collegial) or the stakeholder (corporate) models (Bleiklie \& Kogan, 2007). These governance models are reflected in the way governance structures are organised within universities (Saint, 2009). Within collegial governance council decisions tend to be made by a strong committee of scholars or professors within the university, whereas the stakeholder model incorporates various types of external members within university councils. Since university councils are governing bodies, their composition is crucial in exercising power and authority in decision-making for the university. 
In their composition of university councils, the French and Portuguese speaking African universities tend to adhere more to the republic of scholars governance model, while the English speaking universities to the stakeholder model (Saint, 2009).

The Malawi system seems to have a balanced membership that incorporates external members in its university councils. For example, the University of Malawi Council comprises the following members: the chairperson appointed by the president; the vice-chancellor; the principals of the constituent colleges; the Secretary for Education or his designated representative (ex-officio); the Secretary to the Treasury or his designated representative(ex-officio); two members appointed by the chancellor; one member appointed by the University of Malawi ex-students' association; one member appointed by the council from a panel of three persons distinguished in university affairs in Malawi, nominated by the vice-chancellor; one female member and one male member elected by the University of Malawi Students' Union, other members not exceeding four co-opted by the Council (The University of Malawi, 1998). This composition is similar to Mzuzu University's. However, while the composition of the governing bodies in public universities in Malawi reveal a balanced composition, this does not mean that decisions are free from interventionist modes of policy-steerage as data reveal in chapter 9. The next chapter engages with the new-managerialism that is emerging in Malawian universities.

\subsection{The emerging new-managerialism in Malawian universities}

As noted, following the requirements of the new-managerialism, in recent years some African countries have begun to enhance monitoring mechanisms for their universities (Saint, 2009). It can be argued that African countries such as Malawi, are gradually moving toward the state-supervising university policy-steerage model due to the interaction between neoliberalism and the 
knowledge economy discourses (Olssen \& Peters, 2005). The next section offers a critique of this emerging new-managerialism within the university sector in Malawi.

\subsubsection{Critique of the new-managerialism in university governance}

The Malawi university governance system is gradually showing signs of embracing the new-managerialism at least, as spelled out in recent policy documents cited. Since there seems to be a gradual move toward this model in Malawi, the critique here follows a policy-futures approach. This means that the critique is about anticipated problems of the model using debates emerging from countries where this mode of governance has fully been adopted. This critique is important for university education planners, policymakers and policy analysts in Malawi as it helps us understand antidemocratic practices within the university sector.

New-managerialism fosters private-sector methods to public sector management such as to university education institutions (Beckmann \& Cooper, 2004; Beckmann, Cooper, \& Hill, 2009; Davies, et al., 2006; Gewirtz \& Ball, 2000; Hall, 2005; Rizvi \& Lingard, 2010). Globally, literature reveals several problems that have arisen when the private-sector techniques are employed in university governance. The new-managerialism with its neoliberal logic has altered public universities by stressing efficiency, accountability and performativity (Chou, 2008; Olssen \& Peters, 2005). Following these demands, university chancellors conduct their duties as business chief executives and are not concerned with the education endeavour (Marginson, 2002).

Davies, Gottsche and Bansel (2005) use a Foucauldian idea of governmentality (the silent or uncritical acceptance to be governed in particular ways) to argue that neoliberal views employed in the new-managerialism in university education are posited as the unquestioned in that they demand university stakeholders such as academics to be loyal to vice chancellors whose job is to 
run universities as chief executives. Thus, university governance within the new-managerialism rhetoric impedes debate within the university as debate can be viewed as disloyalty to chief executives mandated to galvanise resources for the university (Davies, et al., 2006; Olssen \& Peters, 2005). While neo-liberalism and the new-managerialism are not necessarily homologous notions, they influence each other. This idea is well captured by Olssen and Peters (2005) who contend as follows:

\begin{abstract}
A further consequence of marketisation has been the increased emphasis on performance and accountability assessment, with accompanying use of performance indicators and personal appraisal systems. This has generated a concern with corporate loyalty and the use of discipline against employees who criticise their universities. Universities in this model have become concerned with their market reputation and become increasingly intolerant of adverse criticism of the institution by the staff. Such policies are the logical outcome of privatisation: in the private sector employers are not permitted to criticise their employer in public. Under neoliberalism corporativisation many universities are employing advertising and public relations agencies to ensure that only positive statements appear about the university and it products (Olssen \& Peters, 2005, pp. 327-328).
\end{abstract}

Consequently, state-supervision or new-managerialism is viewed in this thesis as following instrumental rationality that impedes communicative rationality necessary for democratic university governance. According to Olssen and Peters (2005), neoliberal governmentality has given rise to shifts from collegial or democratic governance models to imposed management models of powerful less-powerful chains of command. These anti-democratic ways of university governance are further reflected through imposed workloads and course content on academics which erode the traditional notions of academic or professional autonomy in teaching and research (Olssen \& Peters, 2005). As such the emergence of the market forces in university governance in Malawi can be seen to be pointing to a direction that is woven within instrumental rationality, which impedes democratic deliberation generally and is antidemocratic. 
Giroux (2003) bemoans these market forces and the new-managerialism in university education and governance and contends as follows:

Fundamental to the rise of a vibrant democratic culture is the recognition that education must be treated as public good - as a crucial site where students gain a public voice and come to grips with their own power as individual and social agents. Public and higher education cannot be viewed merely as sites for commercial investment or for affirming a notion of the private good based exclusively on the fulfilment of individual needs. Reducing higher education to the handmaiden of corporate culture works against the critical social imperative of educating citizens who can sustain and develop inclusive democratic public spheres (Giroux, 2003, p. 182).

Further, Giroux (2003) contends that new-managerialism has brought new ways of governance in which the management model is one that replaces faculty governance (i.e., the community of scholars) with that of the language of accountability which impedes democratic governance. As such, university students are conceptualised as human capital in need of training for paid work at the expense of a broad based critical pedagogy (Beckmann, et al., 2009). University education is different from training and there is a need for academics to resist market forces (Giroux, 2003). As noted, the market forces weaken the critical nature of the university (Giroux, 2003).

Another problem that arises within the new-managerialism is the conceptualisation of what it means by knowledge and what type of knowledge universities need to impart (Peters, 2003a). Peters (2003a) argues that in the age of global capitalism within which new-managerialism takes primacy, there are struggles not only over the meaning and value of knowledge but also over the means of knowledge production. For example, Hall (2005) contends that new-managerialism has shifted the focus from educational purposes and politics in education to an emphasis on what works. What matters as knowledge therefore, is that which can be measured and as such scientific evidence that proves what works, is legitimated as knowledge (Hall, 2005). By implication and following on from Peters' (2003a) argument, this alters not 
only what it means by knowledge, but also the ways knowledge is produced and communicated within the university. In the same vein, Hall (2005), poses the question "what are the policy implications of a policy mission that focuses narrowly on providing solutions to, rather than stimulating ongoing deliberations about educational problems" (Hall, 2005, p. 182).

It is noted that students prepared for the market only, lack the required deliberative mechanisms to engage with the public (Beckmann \& Cooper, 2004; Beckmann, et al., 2009; Giroux, 2003). As such, market forces in university education mould learners within instrumental reasoning, which impedes their abilities to embraces communicative rationality.

More so, these market forces have been viewed as exacerbating social injustice. In England for example, studies show that market forces have encouraged inequality in accessing education resulting into class problems (Beckmann \& Cooper, 2004; Beckmann, et al., 2009; Whitty, Power, \& Halpin, 1998). Similarly, it is expected that given the adherence to market forces, these changes in Malawi shall affect the poor who will fail to manage to meet costs for university education generally.

\subsection{Conclusion}

This chapter has discussed global changes in university governance and their impact on university governance in Malawi. These global changes, which adhere to global-neoliberal-orthodoxy and the knowledge economy discourses, are forcing universities to embrace mechanisms of the newmanagerialism for governance. The chapter presents the argument that these mechanisms impede democratic governance as they are based on a performative and monitoring culture that resembles business models. Moreover, the global-neoliberal-orthodoxy and the knowledge economy discourse demand aligning university education to industry at the expense of 
critical pedagogies. They are, as such, viewed in this thesis as following the instrumental use of reason and being anti-democratic. This chapter has therefore helped to show that the global-neoliberal-orthodoxy discussed in chapter 6 gradually permeates university governance in Africa generally, and in Malawi, in particular. 


\section{CHAPTER 8}

\section{Governance and administrative practices at university level in Malawian universities}

\subsection{Introduction}

This chapter explores the nature of anti-democratic practices at university level governance based on data. Drawing on data from semi-structured indepth interviews, the chapter reveals that the major challenges to governance at university level in Malawi emanate from rivalry relationships among university stakeholders which constrain decision-making processes. In reference to the rivalry relationship among stakeholders, respondents' views are reflected through data showing the following: strife between academics and university managers, strife between students and university managers and strife between students and academic members of staff. In reference to constrained decision or policy-making at university level, respondents' views revealed constrained collegial or faculty-led university governance with poor participation in decision-making by staff and students and lack of proper consultation on some issues. The two major findings are interrelated. While the level of problems and strife differs from one institution to another, overall, the chapter shall show that democratic or collegial governance and administrative practices at university level where they exist are undermined by neopatrimonial attitudes.

Based on these findings, the chapter makes the argument that the neopatrimonial attitude of presidentialism or big-man alluded to in chapter 2 permeates governance and administrative practices in universities and renders them in the most, anti-democratic. Viewed within Critical Theory, the chapter shall show that power struggle within universities facilitated by presidentialism or the big-man syndrome impedes both dialectic reasoning as 
well as communicative rationality among stakeholders within the running of universities in Malawi. The data are presented as outlined above. It, thus, begins with discussing the rivalry relationship among stakeholders.

\subsection{Rivalry relationship among university stakeholders}

As shall be shown, rivalry relationships among university stakeholders reveal problems of misuse of power mainly stemming from the neopatrimonial attitude of presidentialism or the big-man syndrome that permeates the governance of universities in Malawi. As noted throughout, from a Critical Theory perspective, this thesis unveils problems that hinge on misuse of power, which is not measurable as in positivist theorising. This is important to bear in mind as data were analysed within macro parameters and following self reflexivity that enables the researcher to suggest social changes as argued in chapter 5. Following is a discussion on strife between academics and university managers.

\subsubsection{Strife between academics and university administrators}

Respondents' views revealed that democratic governance and administrative practices are impeded by strife between academics and university managers in most Malawian universities. The questions asked aimed at understanding problems within universities, especially between academics and university administrators generally.

Data show that strife between academics and university managers is caused by the following: poor handling of staff salary increment requests and welfare related issues, lack of trust between academics and university managers, lack of transparency in usage of funds, misuse of academic freedom, differences in 
qualification between academics and administrators and lack of transparency in appointing university leadership. These issues generally show the misuse of power common in neopatrimonial modes of rule, which are ingrained in Malawian society as argued in chapter 2 .

Poor handling of staff salary increment requests seem to bring intense tensions between academics and administrators in Malawian universities especially in public universities. One university manager averred the following:

Well for a long time the management of universities in this country and in Africa in general were a microcosmic representation of what was happening at the top. Because administrators were interacting with the Kamuzus ${ }^{5}$ of our time; they knew how tough it was to reach the top. And they never were able to explain that when we go up there we are just told off. So they failed to explain that the people at the tower behave this way. So you had two groups that had a different understanding of what was happening. Academics tended to view administrators as part of the oppressors, the politician, and administrators and government used to see academics as troublemakers. So when it came to difficult matters of salaries it was like they belonged to different camps.

The manager highlights problems with usage of power by post-colonial state presidents who were also chancellors of public universities and how this affected the running of the universities in Africa generally. These presidents such as Banda in Malawi tended to exert total control on university management and governance reflecting the big-man syndrome (Kerr \& Mapanje, 2002; Sturges, 1998). In Malawi, there was as such, a general tendency for university administrators to side with the government which perpetuated strife between university administrators and academics. While the manager seems to argue that this situation was prevalent only during the dictatorial time in Malawi, as data show, the tendency is evident in Malawian universities and is still a source of serious tension. For example, one academic member of staff mentioned the following:

\footnotetext{
${ }^{5}$ Kamuzu was the first president of the Republic of Malawi and dictator. The usage here means "dictators"
} 
I would say probably there is pretence. When it comes to issues of general welfare of staff members such as salary increment it is always assumed that members of staff are always in need of increased salary increments while the management is against that. But by the end of the day what happens is that both are winners. Whenever the issue has been implemented both management and staff members are winners. But the union is always seen as acting against.

The academic makes the argument that the tendency to have two opposing camps in dealing with salary increment issues is rife. The sentiments presented reveal that there is a lack of communicative rationality between two sides in dealing with the issue. In a democratic environment one would expect that the two sides engage in dialogue to solve such problems. The tendency for university managers to side with the government or the powerful stifles a need for deliberation and reflects the big-man syndrome permeating within the university governance systems in Malawi. Consequently, this tendency adheres to instrumental reasoning in which university administrators collude with the government machinery to exert control over the academic staff as used to happen during the dictatorial time. The administrators are perceived as benefiting more from the system than academics in Malawian universities as one academic member of argued:

The main problem is that they (university administrators/managers) ${ }^{6}$ themselves have plenty allowances and they do not see the need for this one because they are already well covered. They have got fuel allowances but look at a member of staff, of course they have a research component but the money is little...

It can be argued that the fact that university managers or administrators benefit more than academics through the university governance system, they easily side with the government. The siding of university administrators with the government makes it easier for university administrators to exert manipulative control over academics in Malawian universities. As noted, it can be said that this powerful less-powerful relationship within the university results into a lack of enabling mechanisms for democratic deliberations and eventually hinders most university leaders to think dialectically or to be self-

${ }^{6}$ My addition in brackets 
reflective about their leading practices in order to improve the running of universities (Carr \& Kemmis, 1986; Habermas, 1984, 1987; Waghid, 2003). In some instances, the tension between academics and university administrators over salary increment wrangles has been so intense that the university management in some institutions has used its powers to commit academics to court as one academic member of staff explains:

.... it was the same salary issue when members of the union decided to go on strike and our employer the university council pointed out that the strike was illegal because previously they had gotten an injunction restraining us to go on strike until certain things were reviewed. So what happened was that we were in contempt of court and the council selected seven of us to be committed to court then there after they wanted to follow up on all of us and that sent shivers amongst the members throughout the university.

The sentiments provided by the academic present a good example of a lack of proper mechanisms to iron out problems based on rationality within an institution. These tensions are not helpful in achieving the missions of universities in Malawi. The poor handling of salary increment requests seem to have the potential of demotivating academics in their endeavour, which is one area that the Malawi government would like to improve as stipulated in the Malawi Policy and Investment Framework (Malawi Government, 2000a). As argued in chapter 4 however, the Malawi Government's perspective of motivation hinges on measurable issues only without understanding how the big-man syndrome permeates university governance such that it is the way salary requests are handled that requires more attention. The lack of morale is expressed by one academic member who said the following:

I would describe it (motivation) as extremely low because now people are tired since they have tried this and that staging strikes but still the employer is somehow winning. I think their strategies are somehow winning because they know that once you take time when the fight takes a longer period of time some people get back. But somehow we call ourselves as a submarine that is in the waters and any time it can emerge.

The constant tension seems to build helplessness and anger among academics as revealed through the above sentiments. The academic cites delays by the management in solving problems as part of strategies to exert control. It is 
argued that a lack of promptness in solving such tensions impedes dialectic reasoning and communicative rationality. Further, the sentiments reveal the powerlessness of academics in the face of the powerful university managers who are the only ones endowed with power to make decisions, which reflects the big-man syndrome. The anger and helplessness among academics can be said to prompt revenge as they view themselves as submarines submerged in waters that can emerge anytime, to fight back when necessary. Such tensions limit deliberative modes of decision-making as people begin to become strategic or teleological, hence instrumental (Habermas, 1984). Commenting on salary and welfare related issues between academics and administrators another university manager argued as follows:

... They (staff) ${ }^{7}$ complained against council policy decisions... in previous years they complained partly against council and partly against management. But they were for very specific instances and when you look at it all complaints...have to do with their welfare more than anything else... (We had) hundreds of meetings between unions and council until matters were resolved you know in all cases where there have been disagreements between the staff members and the council we have resolved otherwise this college could not have been running.

The manager alludes to problems of welfare that academics complained about. These problems generally hinge on salary as noted. While the manager argues that in trying to solve welfare problems, several meetings were heard, given the earlier discussion, the problem is that university managers tend to take the government's side, without exercising the use of reason required. In other words, such meetings become difficult as both sides become strategic, which stifles communicative rationality that requires adherence to respect of participants' views, inclusivity of representatives and a commitment to resolving problems using reasoned arguments without the use of force (see Habermas, 1984, 1987). Responding to a similar question, another university manager mentioned that strife between academics and management will always exist in Malawian universities by positing the following:

${ }^{7}$ My addition in brackets 
There will always be conflict between the management and academic staff because there is an inherent suspicion that the administration are in control of resources and they are the ones who are consuming most of the resources which could have been used by the faculties.

The university manager argues that there will be perpetual strife between academics and administrators in Malawi due to the inherent suspicion that the management or administration is in control of resources and benefit more from them. Although this view has been already alluded to, it is important to note that as presented by the university manager, here it explicitly reveals the powerful less-powerful relationship where those who have resources are more powerful and tend to make decisions for the powerless that is common in neopatrimonial modes of rule as argued in chapter 2 (see Erdmann \& Engel, 2006; Gilman, 2001, 2004).

All in all, the handling of salary increment requests and related welfare problems cause tension within Malawian universities due to lack of deliberative mechanisms. This facilitates an environment in which academics and university administrators become strategic or instrumental in their use of reason. The general challenge stems from the usage of power by the powerful revealing the big-man syndrome that permeates university governance.

Data reveal that the other major problem that contributes to strife between academics and university administrators in Malawian universities is a lack of trust between the two groups. As can be deduced from the data, the lack of trust stems from misuse of power by those in leadership positions and it exemplifies the neopatrimonial attitude of the big-man syndrome alluded to earlier. The lack of trust is a result of previous problems discussed. One academic member of staff mentioned the following: 
The other challenge could be how we are viewed by our employers they think that the union ${ }^{8}$ is a club of troublesome people. Whenever we want to say something they kind of verify who is there and who is not there...

Instead of working together to achieve academic goals and missions of the university, the academics are viewed by the managers, the powerful, with suspicion. This suspicion exacerbates tensions as it breeds fear and lack of trust between the groups. Working within an environment in which stakeholders do not trust each other forces stakeholders to think in ways that can be manipulative or adhere to social control (Habermas, 1984). For example, according to the academic, since the university management is endowed with power, it manages to isolate academics that seem to be troublesome. It is important to note that being troublesome in such antidemocratic environments might mean being critical. The situation represents a kind of power struggle in which strategic or instrumental reasoning is employed to instil fear by the powerful who then fail to exercise self-reflexivity and communicative rationality. Another academic lamented about the lack of trust between academics and university managers and averred as follows:

It is unfortunate that the staff union is seen as a block against management. It is not supposed to be like that. It is supposed to be like a bridge between the members of staff and management but as of now in most cases it is seen as block or a tool to force management to do things which they assume are against their planned activities...

The academic member of staff argues that it is unfortunate that the management views staff unions or social welfare groups as blocks that force management to do things that they do not plan for. The statement by the academic reveals a perpetual tension or fight between the two groups at the university. In arguing that the staff union is supposed to be like a bridge between the members of staff and management, the academic is in favour of a kind of communicative rationality to be facilitated between the two camps in

\footnotetext{
${ }^{8}$ Staff Union is used generally to include academic social welfare groups. During the time of research, of all universities and university-colleges, it was only Chancellor College that had a registered staff union.
} 
which reason-giving and not control ought to take primacy. On the same question, another academic mentioned the following:

I think there is lack of trust (between academic staff and management) ${ }^{9}$. The relationship is very bad... we want to show that we can paralyse the system because management has shown that we are not necessary people, they have shown that they are arrogant and if somebody is arrogant we respond in a similar way. Sometimes reminding them of past experiences that this is what "your friends saw and if you are not careful you may also face the same" 10 .

Like the other academic responded before, although academics see themselves as powerless, they are able to paralyse the system in one way or the other. The sentiments of the academic above reveal constant tension, fear and lack of trust between the two camps which results into anger and helplessness especially among academics. Academics remind managers of experiences of past managers who were removed unceremoniously at the demands of academics. The constant fight, helplessness, anger revealed here exemplifies the misuse of power common in neopatrimonial modes of governance, which as noted, militates against both dialectical reasoning and communicative rationality within leadership. In neopatrimonial logic, the powerless are meant not to question the powerful who see themselves as providers and in control (see Booth, et al., 2006; Engel \& Erdmann, 2007; Gilman, 2001, 2004). The control over academics facilitates instrumental reasoning among academics that consequently resort to finding anti-democratic ways of paralysing university governance as one way of showing their anger or helplessness.

All in all, lack of trust among academics and administrators within Malawian universities hampers democratic governance as it facilities manipulative thinking that militates against both didactical reasoning and communicative rationality.

\footnotetext{
${ }^{9}$ My addition in brackets

10 My parenthesis to the respondent's statement
} 
Data show that lack of transparency in usage of funds is another factor contributing to anti-democratic practices within governance and administration in Malawian universities. One academic member of staff mentioned the following:

...There were some lecturers who were teaching...and were supposed to be paid extra money because they were teaching outside the programme...the director of finance thought that they were paying lecturers twice. Now it also happened that there was money...which [university managers] shared. So when lecturers heard about it they queried as to why they were not given any money but people who did not work were... By the end of the day it was true that the money was shared and they were forced to pay the money back...

The academic mentions a situation where managers use their powers to misuse funds within universities. This represents a lack of accountability and transparency in the running of universities. Lack of accountability in usage of funds reflects the big-man syndrome that some university managers harbour in Malawi. Misuse of funds and lack of transparency is generally rampart within neopatrimonial modes of governance (see Gilman, 2001). On the same topic, one university manager said the following:

People must know where the funds are coming from how they should be used, how best we can use the funds for, because at the end of the day strife is always about resources. Sometimes there is an imaginary belief that resources are there so we need to be transparent that is why I referred earlier...to transparency in administration of finance and resources...

The manager argues for transparency on usage of funds within the universities and acknowledges that strife or strikes at the university are always about resources. It can be argued that transparency fosters openness in the running of universities and is as such helpful in achieving democratic university governance. Overall, lack of transparency in Malawian universities reflects the big-man syndrome and instrumental use of reason that require changing.

Data show that some university managers attributed the strife mostly to academic freedom. Academic freedom can be defined as the ability of academic staff to teach, conduct research and publish without outside interference while 
university autonomy as the power to govern without outside control (Richard \& Anderson, 1998). On advancing that academic freedom causes strife within the university, one university manager said the following:

That a university has got academic freedom means a lot. It means a lot because it is saying that in as far as the faculty is concerned, in as far as individuals within the university are concerned they are free to do what they can do. So, that is related to knowledge, to discover and create knowledge you cannot restrict knowledge in an academic freedom... Academic freedom comes in conflict with the management in the sense that while the management is interested in running the university, at the same time the management is answerable to the external that is the government. Now the government has its own expectation that is bureaucratic expectations which says that they do not expect the university to engage in politics, not to discuss with the opposition... so that brings a lot of conflicts between the faculty and the management.

From the argument presented by the university manager, it can be deduced that while management of the university is interested in the smooth running of the university, it gets caught up with government agendas, further giving an example of the misuse of power alluded to earlier. It can be argued thus, that other than just a lack of academic freedom, this view is related to challenges of institutional autonomy. In this case, academic freedom is perceived to be problematic and a cause of strife between academics and university managers not because of academics per se, but because university autonomy is curtailed by the government. Another university manager expressed the academic freedom view as contributing to strife between academics and university managers as follows:

This has to do with what is called academic freedom in universities...in the academic world you are trained in a particular field and it is not a job that anybody can just fill in. And that gives a lot of authority to individual members of staff... they are in control of their own expertise and the work that they do that is where the academic freedom comes from. So it is the nature of the institution and the nature of the jobs people do that contributes to this. The other reason is that academic staff being authorities they speak from a point of strength there is nobody who speaks from a point of weakness. If you have your qualification from a good university and you have done your research you can go and do that anywhere in the world as long as your services are required. It is not exactly the same if you are in the private sector. 
The idea presented because of academic freedom academics speak with authority, and, as such, the nature of their job contributes to the tension with management of universities is debatable. The major problem as revealed in this thesis is the fact that those in power crave for total control which stifles academic freedom generally. All in all, the academic freedom view as causing strife within the university sector is debatable. However, as discussed in chapter 9, academic freedom in Malawian universities is stifled by the government following the big-man syndrome mechanism.

The other cause of strife mentioned by respondents was the difference in level of education attained between academic staff and administrative or management staff in Malawian universities. This problem is woven within power relations. The problem is well expressed by a university manager who mentioned the following:

In the past priority for training used to go to academic members of staff who tended to be better qualified than their administrative colleagues. Now things have changed, such that people like ourselves have gone under specialised training such that when people are arguing we can counter argue from a position of professional preparedness other than from a position of intimidatory power. And you know that now we can argue based on who better understands the concepts. So even ourselves before we say anything we start asking ourselves, is this workable? Am I capable of defending this when the time comes? Similarly the academics have realised that merely saying that I am an academic and you are an administrator is failing to back issues with facts, there must be rationality. So that again has now reduced the tension of academics and administrators who viewed each other as foes and not as partners.

The issue presented by the university manager above reveals how differences in qualifications contribute to tensions between academics and university managers in Malawi. The problem highlighted shows that in the past, the administrators or managers, who as noted, are endowed with more power than academics within Malawian universities, employed power of force and not of reason in their dealings with academics. However, although the manager would like to portray that this is no longer the case, as shown by previous data, 
the spirit of control and coercion by managers and administrators is still rife in Malawian university facilitated by the big-man syndrome.

Some argued that the tension was due to lack of transparency in appointing university managers. For example, one university manager mentioned the following:

Actually in the old days there were no transparent ways of appointing leaders. With the dawn of multiparty politics the University Act was revised and the revision examined all these issue that you are mentioning. Now that everybody knows how these people are appointed, now that everybody knows that these people are not imposed but are democratically appointed hostility towards them has been greatly reduced.

The university manager holds that hostility from academic staff toward university managers has greatly reduced because unlike in the past when university managers were imposed on the university now they are democratically appointed. While this might be the case, since the state president nominates chairpersons of university councils and approves university level principals (Mzuzu University, 1997; The University of Malawi, 1998), it is arguable if the system is really democratic given neopatrimonial attitudes that permeate the state steerage of university policy as shall be shown and argued in chapter 9.

The discussion on strife between academic and university managers or administrators has highlighted several ways in which strife is facilitated. Central to findings are the anti-democratic practices that stem from the neopatrimonial aspect of the big-man syndrome and instrumental use of reason. These aspects militate against dialectical reasoning as well as communicative rationality and need to be rectified. 


\subsubsection{Strife between students and university managers}

This discussion will show that strife between students and university managers in Malawian universities is woven within a powerful - less powerful relationship in which the big-man syndrome takes primacy and consequently impedes dialectical reasoning and communicative rationality.

Data reveal that the strife between students and university managers impede democratic governance and administrative practices and have been grouped as follows: lack of urgency in handling students' loans and stationery allowance, experience of freedom after the fall of the Banda regime by students, academic freedom and the questioning-nature of actors within the university and resource-related issues. The discussion starts as outlined above.

Most university students in Malawi depend on government loans to finance their university studies as discussed in chapter 4 . However, the lack of urgency in handling students' loans and stationery allowances seems to cause serious tensions between public university students and university managers. One student leader averred as follows:

The major cause of students' riots is basically the delay in students receiving their book and stationary loans. This loan actually comes from the Public University Trust Fund and whenever there are delays students get interested and almost all the strikes that occurred here... have been revolving around that...As for the riot which we peacefully declared on 22nd of June 2009 which personally I call... a peaceful riot though before that some students had already broken into the university and...blocked traffic,...the management did not...punish the students because they themselves contributed to the sit-in in the sense that they delayed in giving us the book and stationery loan when the loan fund had already remitted to the university the money a week before the riot... 
As can be deduced from the student leader, universities delay to disburse students' loans which lead to strikes within the universities. Augmenting this view, one university manager mentioned the following:

Most of their problems are around the loan scheme. Money coming from the loan scheme, the university is just a facilitator. That money is not supposed to be coming to the university but it was found feasible to use the university as a facilitator. The problem comes when that money comes the students want it like yesterday, the moment you delay by one day it becomes uncontrollable. But it is a loan not a right and students do not seem to understand...

The university manager is in agreement with the student's sentiments that most of the problems that affect students surround the loan scheme which public universities are just facilitators. In the university manager's view, students are not patient to wait for the disbursement of the funds. However, while the university is just a facilitator given the dire need for these loans by students, delays in disbursing loans to students is problematic. The argument presented is that delays in disbursing university loans, especially when funds have been remitted to individual universities, reveals that students are not given priority as university stakeholders reflecting the powerful less-powerful relationship or the big-man syndrome. Second, there seems to be a lack of information flow regarding loan schemes within the universities which reflects that students are not given the respect they ought to receive as stakeholders. This argument is further reflected in the following student leader's remarks:

Normally it is due to poor management styles employed by our college managers. You see, information is very important but they normally give information at the very last minute of the event and sometimes taking people for granted is not ok as well. You will agree with me that there has been a great change. In 2009 I can cite one example with... which used to have a number of strikes in a year, this time they have conducted only one it was something to do with stationery allowance. Students came up to the sixth week without the money and yet the loan trust is there. Of course this was the time of campaign and other people thought that the opposition used the students but this was not the case. So students went on strike but there was nothing like breaking vehicles what what....

The powerful less-powerful relationship between students and university managers or administrators is further shown by the lack of information and 
urgency in dealing with the issue of the student allowance by the university management or administration as argued by the student leader. The students have branded this as poor management style. Commenting on whether university managers explain the delays in stationery allowance, one student leader averred as follows:

... They did explain but the students did not like what they presented as the problem. They actually said that the cheque was supposed to be cleared at the Bank after getting it from the Loan Trust Fund but we know a cheque is normally cleared in four days but it actually took more than five days for the students to get their money so their explanation was not convincing to students. Although after that sit-in, there was an observation that one major university property in the name of a sign post at the gate was destroyed and the Principal Secretary wrote the university a letter that students should pay the equivalence of the damage but some students were saying that actually the damage was done by the police who came to quell down the riot. So it is an issue that is much contested. But the university has not taken any action up to now.

The situation explained by the student, exemplifies a lack of information and proper communication between the student bodies and university managers. It is argued that this reveals the big-man syndrome in which the powerful tend to ignore the powerless as all decisions depend on those who are in control. The big-man syndrome reflected in the relationship between students and university managers through the handling of loan schemes, shows that leaders concerned fail to reason dialectically and to engage with students using communicative rationality. The sentiments are supported by another student leader who mentioned the following:

Basically the management is not careful in handling students' issues and this is what normally causes strikes. I am not saying that all are failures some do achieve but in general terms. I am told that at ... read the today's article in the Daily Times where they say that the other problem was also the way the bus operates. They talked to the management only to find out that the management took the issue very lightly so that is the way things happen.

Referring to a strike that happened at one of the colleges during the time of research, the student further bemoans the lack of urgency in handling students' issues within the universities generally. 
On the whole, the lack of urgency in disbursing students' loans and stationery allowance, which leads to strikes and strife within Malawian universities, reveals the big-man syndrome that permeates university governance. This is because within the big-man syndrome, decisions are chiefly done by the powerful that are in charge while the powerless ought just to follow (see chapter 2). University leaders who belittle students as stakeholders show a lack of dialectical reasoning and communicative use of reason that require respecting stakeholders as part of a reasoning community in decision-making (Habermas, 1984).

Some saw strife between university students and managers as due to the experience of freedom after the fall of the Banda regime. For example, one university manager said the following:

In the history of the University of Malawi it is like beginning from the late 80s when an economic pinch was felt by the university students in that they were asked to start contributing for higher education, they noticed that also under-funding affected the cafeteria, the type of cleaning facilities, even the brain drain in first year they had very capable lecturers and come fourth year that lecturer was no more there. ...when they tested freedom and saw that they could strike and demonstrate they never looked back and they must have thought that things were like that...

While referring to Structural Adjustment Policies that led to the introduction of fees and generally dilapidated the university sector in Malawi (see Samoff \& Carrol, 2003; Zeilig, 2009; Zeilig \& Dawson, 2008) as contributing to the strife between students and university managers, the university manager also argues that when students got freedom to stage demonstrations they began to take demonstrations as normal. While the change to multi-party democracy in 1994 indeed brought excitement among university students, the contention in this thesis is that the causes of strife between students and university managers hinge on the dictatorial hangover that characterises the running of universities exemplified in the powerful-less-powerful relationship. As such, whereas there is some merit in putting some blame on students, more has to 
do with how the students were and are treated within the powerful-lesspowerful relationship alluded to throughout this thesis.

Some university managers blamed the strife between university management and students on academic freedom. An example of this view was advanced by a university manager as follows:

To me, in most cases we are abusing the academic freedom and what is known as human rights. One Member of Parliament said that we must have human rights with responsibility. That is a problem that people have. For example the people in your profession, the people in education at... one time marched to a council meeting. They wanted the teaching practice allowance increased. It was a reasonable request to me because people on similar activities from...and...were getting much more...The problem I had was that they were told that council was reviewing their condition and asked to wait. This happened in October and they were supposed to be going for teaching practice in May next year but they decided to march to our council meeting demanding that we should take their demands on board. I did not see the reason especially that for council it was the first time we were hearing about it. It was not going to be implemented until six months later so they should have pressurised through the channel without going on strike...

As can be noted, the phrase academic freedom seems to be used loosely by some respondents. The university manager posits that students abuse academic freedom and cites Bachelor of Education students at the university who marched to a council meeting to demand an increase in their allowance for teaching practice. Although there was a need for addressing the allowance issues the manager deplored the lack of understanding from the students. The respondent argues that there is a need to have human rights with responsibility. While the manager makes a point that students should have followed normal channels, the problem as viewed in this thesis lies in the lack of urgency and promptness in dealing with students' issues generally mentioned earlier. It can be argued that the lack of urgency in handling students' issues serve as a form of precedence and facilitates an attitude in students to use force in order to get what they want. Probably more related to academic freedom is the following view by one university manager: 
I think one aspect that has to be accepted by many people is to look at the actors of the university system. You will see that the people that go through the university system...are people who are supposed to be intellectually the cream of society...the students who come to the university...are those who have been selected from the secondary school meaning that they are the best in the country, supposedly creative and original and the university becomes an experimenting laboratory... So the assortment of the actors within the university is what results in demonstrations and of course some of them are irrational, some emotional and some of them can be genuine and constructive.

Whereas the argument presented by the manager above has merit, the excitement and creative nature of students will normally be triggered by how they are viewed or treated by the university management or administration. As such, the contention in this thesis is that the powerful less-powerful relationship plays a big role in students' demonstrations in Malawian universities. Students' creativity could be a source of intellectual debate and advancement of communicative rationality within the academy that ought to be encouraged.

Some problems have been related to lack of resources such as lack of lecturers, lack of books and poor food especially in private universities. While these are genuine problems in that Malawian universities have limited resources as argued in chapter 4 , it is the way such issues are handled by university management or administration when demanded by students that is usually at stake. One student leader argued as follows:

We do not have enough lecturers most of them are adjunct...now when it comes to this you find that most courses are not started by the time when we reach mid semester. Now when you try to talk to the administration, they think that we are not there to assist but to organise demonstrations...last year there was one because we had been at the institution for over 10 months but a number of courses were not yet started so there was a mini demonstration to show the administration that we were not happy with the status because if a course is not done it means we were to carry it over. Now carrying over means that the courses would be added later when we have other courses to do, this leads to poor performance and some students are 
weeded 11 because of that. We want to make sure that this should not continue and should stop immediately.

The student leader highlights an important issue pertaining to how resource related issues are handled at the university. The argument presented is that when confronted with resource related issues the administration trivialises the issues and blames students for just wanting to stage demonstrations. In this way university administrators miss opportunities to reason together with students and provide explanations as to why, for example, some courses are not being offered although planned for within a semester. In other words there is a need for communicative use of reason in which only the power of reason irons out misconceptions that may be there in the minds of students. The problems of resources were echoed by one university manager who commented on students' complaints at the university as follows:

...for example lecturer $\mathrm{X}$ is not teaching us well or we want to change the menu and so on, or there are beans at table and most of them who make noise have fees arrears. So we say if you do not pay fees how do you even have to say we do not have enough food. Or for example we rely so much on part-timers so it means we cannot have a fixed time table. The time table has to be drawn in the morning and these are mature students and they are told in the morning that today this is the time table so you cannot plan on your own because you have to go by the people who will come. This is a big problem. But it is something that our students do understand.

In private universities this situation is very serious as one student leader explained:

...the major problem that we also face is that we do not have many lecturers most of them are adjunct because of that you find that those adjunct when they come here they want us to have lessons up to $8: 30 \mathrm{pm}$. Sometimes we have lesson from $8 \mathrm{am}$ to $8: 30 \mathrm{pm}$ which means we do not have time to study. The time we leave the classroom we are tired and just sleep so this also affects our performance as students.

\footnotetext{
11 Weeding is a term used informally in Malawi to describe the withdrawal of students who fail courses to be able to proceed with university studies.
} 
The student highlights the problem that arises due to challenges in accessing adjunct staff to teach at the university. However, one student leader reported a more understanding and enabling situation in dealing with resource related problems at one university by advancing the following:

I think as a new institution we have got a lot of issues that we are facing on both fronts. The previous union was not able to do much not because of their fault I suppose but maybe the university had not really been open to the idea of working with the student union. The students were treated as secondary school... not adults...But now with our union it is a little different because when we came in we said we have to work as partners in the school. Of course we respect the administration but we also are an entity... We are trying to get the administration understand that we are not just students but we are representing students and we can do things which are in conflict with them but not against them for we are working for the same goal. Also as a new institution we do not have enough lecturers. For example, now we have been here for six weeks and some students have not started learning. Sometimes lecturers come sometimes not and we have approached the administration but this is a recurrent problem. But we understand it is because they are trying to recruit more lecturers and we have been here only for four years... but they are trying to recruit a lot of full time lecturers, and the library is still being constructed, there are not enough books and we use our own initiatives to go to town to buy books and so on, but not everyone can afford that.

From the student leader's sentiments, one sees efforts for engagement between staff and students at their institution. This reflects a working or reasoning together that is lacking in most universities in Malawi as per earlier discussion.

\subsubsection{Strife between students and academic staff}

Strife between students and academic members of staff also reveals the bigman syndrome in which the academics are powerful and students less powerful. The argument presented throughout this thesis, especially in chapter 12 is that this syndrome ought to change. One student commenting on the relationship between academics and students said the following: 
Basically, the relationship in many instances has been observed not to be very good. For example if there is a small conflict between a student and a lecturer normally I am told some lecturers do victimise some students. And actually I was privileged to go to the University of... and what I noted...there is nothing like an academic staff victimising a student and I actually captured that during my report as a recommendation that probably the same should be happening here... it was one of the issues that was seriously noted by council and they said that if there is really that problem it is better for the students to report to management... I have evidence because there are so many cases which students have appealed about academic assessment results and so on and most of these have ended... in students' favour.

The student leader argues that the relationship between students and academics at this university is not good. The respondent claims that lecturers tend to mark down students' work or victimise students if they have some conflicts with them. It is interesting to note that such issues get reported to the university council. However, action against lectures may not be guaranteed given the power relations that are at play and have been discussed. Another student mentioned the following:

...so this other gentleman ...was trying to reason with the administrator so one member of the academic staff said what you have to know is that your grades are in my hands...when this issue was reported, we took up this issue to the lecturer in question and what he said was that he was not really meaning it, he was just trying to warn that particular student. But maybe he was not open enough for I think he really meant it.

The student leader gives a further example in which lecturers use their power to instil fear in students using the idea of failing students. This is antidemocratic and a reflection of the neopatrimonial logic of presidentialism. In some cases, students have sought the intervention of courts to curb such behaviours as one student leader explained:

... so the student went to court to challenge the lecturer but I am not sure what the outcome was. I just have to find out what really transpired. I am told some students think that once they are not satisfied with their grades, they fear to go and ask the lecturers for a remark because they say lecturers work to fail such people and they think that they may get them repeat a year or get withdrawn. So as long as they are above a passing grade they think they are safe. But maybe we should find ways in which we could solve such problems. Where students deserve to pass let them pass and vice versa. 
The student mentions a situation where lecturers have been committed to courts for deliberately failing students. The respondent also explains the fear students have to ask for remarks even though procedures for appeals are available. This fear which is a result of the big-man syndrome that permeates governance and administrative practices in Malawian universities curtails intellectual engagement among students and militates against deliberative democratic university governance.

Marking down students' work is an example of the big-man syndrome and the quest to intimidate students by academics. This tendency shows a lack of dialectical reasoning on the part of academics who fail to be self reflexive in order to improve their professional practice. Further, such academics are unable to foster communicative rationality in their dealings with students as they work within instrumental rationality in which their interests are to exert fear and control or manipulate students. Such academics limit creativity amongst students. The last part of this chapter discusses constrained collegial decision-making processes at university level in Malawi which also reveal the big-man syndrome mechanisms.

\subsection{Constrained collegial decision-making processes at universities}

While most university managers' views as well as university level policy documents reveal that governance structures in Malawian universities ought to or follow a collegial or faculty-led governance system, an analysis of data show that constrained meaningful participation and lack of consultation amongst stakeholders in decision-making impede democratic governance. These constraints reveal the big-man syndrome permeating university governance system in Malawi already alluded to earlier. 
As data shall show, constrained participation is revealed by a lax in responsibilities by staff members, lack of active participation in deliberating issues in meetings, over expectation of staff members to the management for decision-making, constrained students' participation in decision-making and a lack of proper consultation among stakeholders within the university. These can be said to be due in part to the big-man syndrome in which power is overconcentrated at the top management which tends to limit the level of meaningful participation in decision-making at lower levels. For example, commenting on participation in decision or policy-making by staff members at university level, one university manager mentioned the following:

... Well the structures are there but are they used effectively? Sometimes they are not. Do people within those structures understand their responsibilities? Sometimes they do not. There is need for a kind of reform...

While appreciating that structures for decision and policy-making are available as most managers explained, the manager questions whether they are used effectively. Following the sentiments of the manager, it can be argued, thus, that while governance structures are meant to facilitate collegial governance there are problems with their effectiveness. While the manager attributes the problem to lack of knowing responsibilities by leaders, there seems to be more than this as revealed by another manager who held the following:

... when a proposal is made you are lucky if you have got full participation of the faculty board. Two, you are lucky that full house participates actively or just lets things go... The expectation is that the faculty administration will be responsible for the active participation of its members...

While noting that structures for decision or policy-making are well articulated, the university manager bemoans the level of participation in decision or policy-making at university level. It can be argued that lack of active participation by faculty members in meetings such as faculty boards reveals the powerlessness that faculty members feel in that their proposals may not be taken into consideration, especially when the system allows meaningful 
decisions to be made at top management only within the big-man syndrome mentioned throughout the thesis. In typical collegial governance the voice of academics respected as the locus of power within a university (Saint, 2009).

Other respondents bemoaned the over expectation of staff members in relation to the management or administration for decision-making. One manager mentioned the following:

\begin{abstract}
...our system here is a faculty system. By the provision of the act and statutes a lot of powers or responsibilities have been placed in the faculties... of course the catch here is that the administration in the name of the registrar is required to provide secretarial services this means that the registrar's office should provide expert advice to the faculty. Ideally the person who should be in command is the dean and his heads of department, the registrar should be coming in to provide advice. Unfortunately this is not happening as a result a lot is expected from the registrar's office. The challenge there is that there is temptation for the registrar's office to appear as if it is administering the faculty.
\end{abstract}

The university manager posits that although the registrar's office is supposed to act only as secretary to the faculties, there is a lot of expectation from the office of the registrar by faculty members which gives the temptation for the registrar's office to appear as if it is administering the faculties. Since the registrar's office is part of the management, the actions of faculty members to over expect from the office explain the hidden power relations. It can be argued that the tendency to over expect from the registrar's office explains the powerlessness of academics to make decisions as what matters in the system is the voice from the powerful management. This is further expressed by the manager who mentioned the following:

...There is a tendency to pass on even minor issues to the highest office at the university. So what we have observed is that normally there are a lot of request that come to the vice chancellor which should really be handled at a much lower level and we suspect that that is because of lack of orientation of staff.

Here the manager bemoans the tendency to pass on minor issues to the highest office and thinks that there is lack of work orientation among university leaders. However, the tendency of passing even minor issues to the 
highest office within the university only shows the problem of the big-man syndrome in which decisions are effectively made by one man or top university management. This is against collegial or faculty-led decision-making that structures of universities in Malawi stipulate.

While in some universities or university-colleges students seem to participate meaningfully in decision-making processes, data reveal a general constrained students' participation in issues that directly affect them across the system. For example, one student leader responded as follows:

Mostly I can say that strategies that most stakeholders are using especially when it comes to decision-making...they seem to avoid students to be part of the decision-making team. As students we are just given decisions that are made elsewhere like imposing them on students which is a thing that we are feeling cannot help the university grow...

The sentiments of the student show that students are not meaningfully involved in decision-making in matters that concern them within universities. While students cannot be involved in each and every decision, every opportunity should be given to them to participate in matters that affect the student community. The quest to limit students' participation in decisionmaking in Malawian universities is also expressed through the manager who stated the following:

The students have been included on council but my experience with them in a council is that the issues that are discussed there are beyond their level because they do not have experience and effort has not been made to teach them how to work with management. Where students' representatives have been integrated within the governance of the university effort has also been made to send them to participate in the committees. You know they go there and just sit like that waiting for when tea will be served... So at the moment they are represented at different committees at college level up to university level but no effort is being made to send in leadership skills on how to participate in these committees. At the end of the day it is time wasted and sometimes they attend a meeting and agree with everybody in the meeting and tell their friends the total opposite. And yet the whole idea for making them to participate was to help them own these decisions. But what happens is when they go back to their friends they change and begin to speak as if they have heard nothing and they do 
not even make an effort to establish what is fully theirs and what is for management.

The manager argues that including students at council is problematic because according to his/her experience no effort is being made to train them on how to participate in the committees. The respondent also argues that sometimes students misrepresent what council deliberates causing problems in the process. If issues hinge on training students, one would argue that universities could facilitate this. This view can be said to be used to justify the limiting of students' participation. One respondent lamented:

...right now we are hearing that the university is intending to remove all the students from the university council...

The respondent expresses the mist surrounding efforts to remove or limit the participation of students' in decision-making at the university. Some universities such as the University of Malawi have proposed a limit on the number of students attending council meetings (The University of Malawi, 2009). This can be interpreted as a way to manipulate students by hindering their voices within campus governance. Limiting student participation at council reveals a lack of creating enabling environment for communicative governance which takes reason as primacy. As argued earlier, this reveals the big-man syndrome in which decisions are not collegial but effectively made by the powerful. Limiting of students' participation at council is also expressed by one university manager who averred the following:

According to the statutes this time we did ask students to be represented but when we sent this to the... he threw away that idea. But they are involved at senate level. When we are discussing the grades the student are not supposed to participate.

The university manager mentions that when a proposal was sent to the chief executive of their university, the chief executive threw away the idea of having students at council. This shows that where real policy issues are to meaningfully be made, student representation is generally limited. 
The big-man syndrome is also revealed through a lack of proper consultation among stakeholders within the university as one academic argued:

...Our employer singlehanded decided to change our conditions of service... if you were interested to be senior lecturer you needed to publish three papers now they added certain things just to make it difficult for you...they did that without any consultation and we have several things of that nature where our employer decided to change

The academic member of staff here generally argues that there are several instances where there is lack of consultation among stakeholders within the university. A case in point is when employers at his/her university did not consult or pre-inform academics in changing promotional requirements. In any democratic governance, one would expect proper information flow. Augmenting the idea of lack of consultation another university manager argued as follows:

\begin{abstract}
Maybe the challenge is that we need to engage more staff meetings and so on. Sometimes I have seen things coming up from colleges and I tend to think they lack consultation so each college is encouraged to consult. In fact, I should have mentioned that we have a very strong principals' committee which meets with the vice chancellor and the registrar regularly. That is where most of the decisions are made and if there is an issue we recommend that it should be debated throughout at college level and then there must be a position paper to be tabled at the principals' meeting after which it goes to the trustees. In fact, we have just decided that principals should also be attending meetings of the board of trustees.
\end{abstract}

While recognising limitations with governance and administrative practices within the academy, some university managers argued that this is due to lack of training of university managers and administrators. One university manager argued as follows:

... the other problem is that we have not made deliberate effort also to offer training of our managers, we tend to think that if you are an excellent academic you are automatically a good manager, it does not work like that. There are people who may not be superb academics but when it comes to organising their colleagues and making them focus, they do the job. So, in the west, now our colleagues are saying you cannot become a head of department, dean, vice principal, head of a research centre before being exposed to higher education management techniques because you command the respect of your 
peers because of how your managerial skills are manifesting themselves

The university manager here sees the major problem with decision-making as a lack of proper training for university managers arguing that to be a superb academic does not necessarily translate into a successful university manager. The view to train university managers is reasonable as long as training supports leaders to think dialectically and employ communicative rationality in their leading. On the same issue another university manager said the following:

People are now talking about entrepreneurial university if you were to ask most lecturers they do not know what it means and yet it is a big thing in the university. People are talking about internationalisation and globalisation or education without boundaries so all these are important in how you run higher education and most people in the universities are not aware of these. One, they relatively new concepts, two, efforts have not been made to make people aware of them so the dialogue is not guided by the language that should accompany higher education.

The manager sees one of the major problems as a lack of dialogue among stakeholders in running the university due to a lack of understanding key concepts that underpin the running of higher education institutions such as internationalisation and globalisation. The respondent thinks that there is a need to make stakeholders aware of these concepts. In this way the manager proposes the need for higher education studies that are not offered in most African universities such as in Malawi. While such training and studies are important in Malawi, there is a need to follow a Critical Theory approach to training in order to address neopatrimonial attitudes such as the big-man syndrome as shall be argued in chapter 12 .

Some university managers suggested ways of curbing what they saw as problems of the collegial decision-making processes. One university manager argued as follows:

...I find the collegial style in universities of Malawi and Mzuzu incorrect relying on a committee system. It is ill suited for our 
universities, people are afraid to take decisions, holding people accountable becomes difficult, when the matter becomes confrontational people form committees to kill the idea by prolonging debate and in the process because nothing moves indiscipline among staff and students increases because they feel there is no force that can hold them accountable. Because of this I think time has come when we need to embrace the corporate culture of leadership. With this culture we need to strengthen the positions of heads of departments, by giving them executive powers, appoint them as opposed to electing them, giving them executive powers so that when the dean notices that someone is not teaching the dean can choose to discipline the teacher. The vice chancellor should be given executive powers.

The university manager argues that the collegial system of decision-making is problematic and proposes what a corporate culture of leadership in which heads of department for example, are endowed with executive powers. The respondent holds that such powers would help in instilling discipline among staff members. As argued in chapter 7, this view is a reflection of the neoliberal agenda which has its own challenges. Further, given the neopatrimonial attitude of the big-man syndrome, granting executive powers to university leaders who may lack dialectical reasoning and who may not engage in communicative rationality, the corporate leadership, may exacerbate fear and anti-democratic practices in the running of universities in Malawi. Supporting the corporate culture of governance, another manager said the following:

...we have a person who can decide because he is always thinking when the time comes to renew my contract it is the same person I would have knocked who would be interviewed, what will he say about me. Elsewhere it is council that appoints the principal and the people of council are of various experiences lawyers, teachers and the combination of their experiences bestows the interviews to a level whereby the end of the day they say this is the person we have picked you have a manager who can be resourceful.

The argument presented by the respondent is that the person heading the university following a corporate fashion will be able to make decisions better than one following the collegial structure of governance because of the accountability principle. This gives the respondent the basis to proposes that council should be vested with powers to appoint principals of colleges other than electing them as is the case now at the university. As argued earlier, this industry oriented governance system, simply follows the neoliberal 
governance logic in which the World Bank operates and is regarded as hindering democratic ideals of the public of scholars conception of the university as argued in chapter 7.

\subsection{Conclusion}

Chapter 8 has presented the nature of anti-democratic practices at university level governance in Malawi. The findings reveal that democratic governance and administrative practices are challenged by the rivalry relationship among stakeholders which leads to constrained collegial decision-making processes. The rivalry relationship is noticed between academics and university administrators, students and university administrators and between students and academic staff. Constrained collegial decision-making processes are facilitated by a lack of deliberative mechanisms among the university actors. An analysis of these views shows that these challenges are due to the instrumental use of reason stemming from the neopatrimonial attitude of presidentialism or the big-man syndrome that permeate the governance and administration of Malawian universities. The chapter further argues that as a result, actors within universities generally lack dialectic leading and fail to engage communicatively with other stakeholders within the academy. To achieve meaningful social change or emancipation at university level governance, there is a need to contain the neopatrimonial attitude of the bigman syndrome. 


\section{CHAPTER 9}

\section{Government university policy-steerage in Malawi}

\subsection{Introduction}

This chapter explores the nature of anti-democratic practices within university policy-steerage by the Malawi Government. Employing in-depth semistructured interviews that concentrated on this major question, the chapter reveals that democratic policy-steerage is hindered by the perceived power of the state president as chancellor of public universities and that, consequently, the usage of such power allows for interventionist policy initiatives. As noted earlier, according to Moja et al., (1998) the interventionist model of government policy-steerage is not systematic and occurs when universities become sites of opposition to usually narrow political direction of the states. Data presented in this chapter, reveal that interventionist university policy initiatives in Malawi tend to follow regionalist political practices that were crystallised at independence, as argued in chapter 2.

While results in chapter 8 reveal that the neopatrimonial attitude of presidentialism or the big-man syndrome, permeates governance and administrative practices at university levels, results in this chapter shall reveal that both the big-man syndrome and the patron-client aspects of neopatrimonialism permeate the Malawi Government university policysteerage. It shall be shown that the big-man syndrome and the patron-client mechanism allow the state president to dominate university policy-making generally and to favour narrow university policies that support the (ethnic) majority in order to garner political support within the regionalist logic. As an example of such narrow policies, the chapter discusses the quota system of university selection. The neopatrimonial aspect of the big-man syndrome, eventually affects academic freedom and institutional autonomy of public 
universities in Malawi. The general argument presented is that the neopatrimonial practices reflect instrumental reasoning and a lack of communicative rationality among government leadership concerned with the university sector. This chapter discusses the controversial role of the state president as chancellor of public universities, the quota system of university selection policy and challenges to academic freedom posed by the neopatrimonial attitude of presidentialism or big-man syndrome.

\subsection{The state president as chancellor of public universities}

The role of the president as chancellor of public universities in Malawi is generally viewed as problematic. Most university managers in Malawi argued that having the state president as chancellor makes it is easier for universities to get government support, but evidence from this research shows that this arrangement impedes democratic university policy-steerage. As noted, the system of having state presidents as chancellors of public universities was facilitated by a need to align African universities to national development (Moja, et al., 1996; Zeleza, 2003). As stipulated by university Acts in Malawi, the arrangement ought to be ceremonial. Public University acts in Malawi, describe the role of the state president as chancellor as follows:

1. That whenever present he/she shall preside at all ceremonial and other congregations and in the name of the university confer all degrees, diplomas and certificates of the university.

2. That the chairperson and the vice-chancellor shall keep the chancellor informed concerning the general conduct of the affairs of the university and shall furnish him/her with such information as he/she may request on any particular matter relating to the affairs of the university. 
3. That he/she shall exercise such other functions and duties in relation to the university as are conferred upon him/her from time to time by the statutes (Mzuzu University, 1997; The University of Malawi, 1998).

Although, as described in the university acts, the role of the chancellor is meant to be ceremonial, based on the data presented, the argument offered in this section is that the expectance by university managers that it is easier to get support from the government if the state president is chancellor, gives the president perceived powers, which perpetuate neopatrimonial aspects of the big-man syndrome and patron-client mechanisms in government university policy-steerage in Malawi.

Respondents' views about the role of the state president as chancellor of public universities have been summarised as follows: that while it is easier to get support from the government the role of the president as chancellor of public universities curtails the independence of universities; that some presidents lack the ability to understand the role of the university and that the role is in place due to the fear that universities can cause political problems if the state president is not chancellor and that the role was a normal political issue during the dictatorial regime.

Advancing the idea that while it is easier to get support from the government the role of the president as chancellor of public universities curtails the independence of universities, one university manager mentioned the following:

... it depends on the situation. It is possible that having the head of state as president you create problems, but at the same time having the head of state as chancellor we have also an advantage in that if you need something you can easily go to the chancellor who is head of state and get what you want whereas an independent person has to go and negotiate with government so you are increasing the number of players in terms of negotiating with government.

While mentioning that in some cases the role could be problematic, the advantage of the role according to the respondent is that universities can 
easily benefit from the president if he/she is the chancellor. Further, the respondent posits that an independent person has to go and negotiate with government first before he/she can get help for the running of a university. This view grants the president perceived powers due to the fact that he is perceived by university managers as being in control of resources required by the university, which can only be easily accessed through him. It can be argued that in this way, the president is presented as the big-man in control of resources badly needed by the universities. As already noted, Gilman (2001) posits that following the neopatrimonial logic, the idea of the big-men having resources tends to lead to blind loyalty by those who do not have resources to those endowed with resources and this could help explain the attitude displayed by university managers in this case. One would expect a proper university system in which universities are given required resources without necessarily depending on the generosity of the president who is the powerful and the big-man. Echoing the big-men with resources idea, another university manager said the following:

...when you have a benevolent chancellor it means that you can easily go to them, talk to them about your problems and they can easily give instructions to technocrats to do what you want...Certainly, the experience has been that since the current president took over in 2004 we have been pulled out of the $60 \%$ funding to something like $70 \%$ and I do not think that there are that many countries in the world that are getting $70 \%$ of what they ask for.

The respondent's argument here shows that the help that universities get within this structure is based on the benevolence of the chancellor, the state president. In such cases, according to the respondent, if the chancellor is benevolent, he/she can easily instruct technocrats to facilitate the support that universities require. The perception of such university managers makes it possible for the chancellor to dominate policy-making using the power of resources and exert instrumental control that stifles communicative rationality and democratic governance. Thus, while there may be some advantages with the role, some respondents argued that it curtails the independence of public universities. One staff union leader mentioned the following: 
...that makes the university not to be independent of government. You know the university is established by an act of parliament and is supposed to be an independent body but whenever you have a chancellor who is head of state and government I think in Malawi it has shown that it is not easy to separate things. People have taken directives from the government as something that is in the university act forgetting that the university is independent and should listen to the senate... Whenever council is making decisions they have in mind the president so whatever decision they make is not independent.

According to the experience of the above union leader, the role given to the president as chancellor militates against the independence of the university. In Malawi, as argued by the respondent, university stakeholders easily accept government directives at the expense of the university's independence. This can be said to be the result of treating the president and government within the big-man syndrome logic. It is not surprising, then, that the respondent posits that this affects policy-making bodies such as councils, as they tend to listen to the state president, the big-man, instead of following what their university acts (ratified by the Malawi parliament) stipulate. This is possible in a situation where the chancellor or the president is presented as the big-man and who is endowed with perceived powers to make decisions for the running of the universities. As mentioned in chapter 2, Booth et al., (2006) argue that the powerful less-powerful relationship found in neopatrimonial rule, is very common in Malawian society due to poverty. As such, in Malawi, this dependency on the powerful individuals makes concentrated authority and dependency normative and can be said to be the taken-for-granted that reinforces neopatrimonial aspects, even at, for example, the Malawi Government university policy-steerage level. Another university manager averred as follows:

In a way, this issue in Malawi has been to some degree a benefit to the university because the chancellor, the state president has identified himself with the higher education sector. That identification commits the government in a way to respond to the need to develop higher education...Nevertheless there is the down side in that the independence of the university to some degree is curtailed in that it has to be aware of the government policies and if the policies are not to the national interest then it can be difficult to speak out for various reasons and to be able to be an impartial advocate for higher education. 
While the university manager's remarks show that in some ways the role of the state president as chancellor of public universities in Malawi has been beneficial to the country in that the chancellor has identified himself with the university, the independence of the university can be curtailed in that the role makes it difficult for people to speak against the state president. It can, thus, be seen as a way of stifling people's voice as people generally fail to question the president in a powerful-less -powerful relationship of the big-man syndrome. In this case, the role impedes values of deliberative democracy in university policy-steerage as the system does not allow for communicative rationality in its policy-steerage. This danger is well expressed by the university manager who opined as follows:

... it can also be a source of oppression. If they want to have a bigger say on how the university should run then they will end up using the managerial powers and exercise political manoeuvre.

Given the perceived powers and the powerful-less-powerful relationship between the president and universities, it is easy for chancellors to become oppressive. As already mentioned, the Banda regime in Malawi is a perfect example of this. It shall be argued next that within the interventionist policysteerage exemplified by the quota system of university selection later in this chapter, exercising political manoeuvre becomes normative. Another example of political manoeuvre is the potential in sacking vice chancellors by state presidents when they work within the big-man syndrome and interventionist logic as one university manager averred:

...It may be noted that having the president of state as your chancellor is not always an advantage...Walter Kamba vice chancellor of Zimbabwe University discovered this when he had president Mugabe as his chancellor. He sacked Walter. A rather similar outcome occurred for Ian Michael, the first vice chancellor of the University of Malawi. Banda arranged a swift departure for him.

The sentiments of the university manager show that when state presidents are chancellors, there is great potential for vice chancellors to be prone to sacking. In Malawi, since the state president as chancellor plays a role in selecting vice chancellors (Mzuzu University, 1997; The University of Malawi, 1998), it 
means that vice chancellors ought to have the support of the president. This has the effect of obliging vice chancellors in Malawian universities to support perceived political agendas which may be narrow and regionalist to avoid being sacked. It can be argued that the system perpetuates the taken-forgranted neopatrimonial attitudes, which have the ability to facilitate injustices, as there is a general lack of communicative rationality in the running of universities within the neopatrimonial logic.

Some respondents argued against state presidents being chancellors of universities in Malawi because some presidents do not have university qualifications to enable them to appreciate what universities do. They posited that the role is in place for fear that universities could become breeding grounds for political turmoil in the country if not overseen by the presidents. In this way, the role can be said to be in place in order to manipulate and control the academy, using instrumental reasoning, which eventually affects academic freedom and institutional autonomy. One staff union leader contended as follows:

It is not on to have the head of state as chancellor because we have a lot of challenges and what if you have a president who has not been to the university, how does he appreciate what goes on in the university? Like the past ten years when we had Muluzi ${ }^{12}$ in power, he never understood what was going on in the university and he could just make funny decisions.

The union leader makes the argument that it is important to have chancellors who have the interest and commitment to the university sector other than having them just because they are presidents of the country. Given the powerful less-powerful relationship, lack of interest and proper commitment by chancellors can only worsen the sector. The respondent further holds that chancellors who have studied and obtained university degrees can understand and appreciate the demands of running universities better than those who do 12 Dr. Bakili Muluzi ruled the country from 1994-1999. He is not a graduate of a university,
however, he has an honorary doctorate degree 
not have university qualifications. However, the qualification view is problematic as educated African leaders such as Banda have also been detrimental to the university sector. As such, the problem seems to be much bigger than the qualification view presented by the respondent. In this thesis, the problem is seen to stem from neopatrimonial attitudes that permeate university policy-steerage. One public officer mentioned the following:

In Malawi, we had one party state and the president was a chancellor of all the colleges. Even during the multiparty dispensation ... we have seen that the president is chancellor even though I think the president has not even seen the corridors of a university 13 . I guess that is done due to the fear of the unknown that may be universities are the cause of sometimes political problems... Maybe it is time we should also be hiring people on merit to be chancellors who could steer and are full time... because the presidents are not full time... I think we need more analysis on this one.

The public officer questions the role attributed to the president as chancellor of the university and opines that it could be due to the fear of the unknown that without the control of the state president, the university would cause political turmoil in the country. In this case, the role can be said to perpetuate the quest to control the academy in a period of multiparty democracy which demands communicative approaches to policy-making within the policysteerage, management and governance of university education as opposed to dogmatic ways such as those characterised by the Banda regime. The public officer reiterates a need to start employing chancellors on merit other than based on their positions as state presidents and stresses a need for employing chancellors on full time basis. The respondent also contends that there is a need for more analysis of the role of state presidents as chancellors of public universities in the country. Such debates are welcome in order to push for a more democratic and workable system that avoids stifling academic freedom and institutional autonomy.

\footnotetext{
${ }^{13}$ The statement refers to Dr. Bakili Muluzi (see footnote 13).
} 
Some argued that the role was political and normal or expected especially during the dictatorial regime. One university manager said the following:

I must say that in the first place it was pure political in the sense that newly independent countries were not democratic at all and the idea of having somebody else as chancellor would not occur. But I do agree with the current observation that it does not follow that if we have this person then things will flow. The least that can happen is personal generosity, when the chancellor gives a donation or so but that money is not sustainable. If you studied the acts of the various universities in relation to the position of the chancellor, it really is ceremonial. It does not attach anything other than the person giving out the certificates... In other words the person has no powers... In other words the chancellor cannot for example close the university in his capacity as chancellor because that is the responsibility of council... The chancellor does not have powers but he has duties.

The university manager makes the claim that the role of the state president as university chancellor was a norm in post-colonial Africa as most African leaders were dictators which made it difficult for someone other than the presidents themselves to be chancellors of their universities. Further, the respondents makes the argument that today, in Malawi, this does not make sense as the role is generally expected to be ceremonial. That this system is still perpetuated in Malawi reveals a quest to sustain control over public universities by the government. As such, the tendency represents the neopatrimonial attitude of presidentialism or big-man syndrome that perpetuates control by a dominant figure.

It is significant within a Critical Theory analysis to mention that in general, the question on the chancellorship of the president and the anti-democratic nature of university policy-steerage by the Malawi Government was sensitive and that some respondents feared to be viewed as if speaking against the current president, the big-man.

In subtle ways however, public universities have shown signs of wanting to get rid of the role of presidents as chancellors of public universities by including in their acts what is expected to happen in cases when state presidents do not 
want to become chancellors, a move which was unthinkable few years ago. For example, the proposed University of Malawi Act of 2009 stipulates that where the head of state decides not to serve as chancellor he/she shall appoint somebody in consultation with the university council who shall serve as chancellor for the duration of the appointing state president's office. Similarly, Mzuzu University Acts of 1997 and 2009 stipulate that where the president declines the appointment of the chancellor, the chancellor shall be appointed by the council in consultation with the minister. However, as can be noted, the two public universities also differ in their stipulation in that according to the University of Malawi, when the president turns down the offer to be chancellor, he/she shall appoint a chancellor in consultation with the council while for Mzuzu University the task is given to its council and the minister. It can be said that these inclusions are signs that slowly there is a quest to review the role but given the fear and the powerful-less-powerful relationship of neopatrimonialism alluded to earlier, this can only be expressed implicitly and cautiously.

\subsection{The big-man syndrome and patron-client mechanisms}

The argument presented here is that the quota system of university selection policy which was rescinded in 1993 and reintroduced in 2009 in Malawi was conceived within instrumental reasoning and that it reflects neopatrimonial aspects of presidentialism or the big-man syndrome and patron-client that follow the regionalist logic mentioned in chapter 2. As such, it shall be argued that the policy is an example of interventionist policy-steerage in which the Malawi Government sought to achieve narrow political aspirations based on regionalist logic.

As noted in chapter 2, employing the regionalist logic and a quest to purge institutions such as universities of non-Chewas generally and northerners in 
particular, in 1989, the Malawi Congress Party Government introduced a quota policy in selecting students to the University of Malawi based on district of origin and district population, which eventually disadvantaged the minority Tumbuka speaking people's access to university education (Kaspin, 1995; Posner, 1995). It can be argued that the Malawi Congress Party Government hoped to gain political support from the Chewa speaking populace as chances of the Chewa speaking people to enter university were widened. Against this policy, four students: Charles Mhango, Ambokire Salimu, William Kaunda and Christopher Chilenga who were admitted to the university on non-residential basis challenged the University of Malawi Council's decision to admit them on that basis and on the basis of district of origin other than on merit (Malawi Law Reports, 2003). Following their application to the court, the High Court of Malawi on 16 July 1993 rescinded the quota policy of selection based on the following arguments:

1. That the university council adopted a government directive without making its own decision on the issue in accordance with the University of Malawi Act and thereby fettered its powers under the said act.

2. That the university council had implemented an academic policy without consulting the senate as it was required under the act.

3. That the decision to base university selection on district quota other than on merit was discriminatory and of no solid foundation (Malawi Law Reports, 2003).

However, despite this High Court rule, in 2009 the Democratic Progressive Party Government decided to reintroduce the policy. While interested citizens have sought judicial reviews more than once, the recent quota policy has been maintained by the courts because those challenging it are not directly affected 
by the policy ${ }^{14}$ as was the case in 1993. It is argued in this thesis that the reintroduction of the policy is a continuation of steps to purge institutions such as universities of northerners that started in the 1970s (see Kaspin, 1995; Posner, 1995). Further, the policy represents the neopatrimonial aspect of the patron-client relationship in which for example both state presidents who pushed for the policy, seem to have done so in a quest to make the majority happy for political gains. The chapter shall also show that the quota policymaking process followed instrumental rationality as opposed to communicative rationality and that all in all the policy exemplifies interventionist policy-steerage by the Malawi Governments (The Malawi Congress Party and currently the Democratic Progressive Party). Data have been grouped into three categories as follows: First, an assessment of views that the quota policy is not anti-north, second, an assessment of the idea that the quota policy is meant to achieve equitable access to university education, and, third views presented against the equity stance.

During the reintroduction of the policy in 2009, proponents of the policy generally refuted that the policy had to do with the participation of the northerners in the university sector. However respondents' views clearly show that this is the case. Commenting on the rationale for the quota system of university selection policy one student leader said the following:

This is a political issue and that is why I cannot really tell. I am told that some people think that the corridors of the university are being filled by people from the north who are working very hard in order to see Blantyre ${ }^{15}$. So we are saying is that a problem if a person works

\footnotetext{
14 Refer to: http://www.malawilii.org/mw/cases/MWHC/20101.htm1: S v Council of University of Malawi, Ex-Parte in Re: Longwe and Another (138 of 2009) [2010] MWHC 1 (21 January 2010)

${ }^{15}$ Blantyre is the commercial and largest city of Malawi. It has two constituent colleges of the University of Malawi: The Polytechnic and the College of Medicine. Since the Northern part of the country is the least developed, the response presented shows the derogatory view of some people in Malawi that students from the Northern region work hard in school to qualify for university entry in order to see the largest city or in general to see the more developed Central and Southern parts of the country.
} 
hard that is alright. Someone is busy with nyau ${ }^{16}$ and you expect him to go to the university?

The sentiments of the above respondent help to explain the rationale for the quota system of university selection in Malawi: the fact that people from the northern part of Malawi are said to be benefitting more from university education in the country than those from other regions (see appendix 12). Although this seems clear, accepting that the policy had to do with the participation of northerners to the university was avoided by officials who were afraid of regionalist tones as the data shall show. The respondent, however, brings forth an important observation: that those students who qualify for university entry benefit from their hard work. Given the competitive access to university education in Malawi discussed in chapter 4, students have to work extra hard to afford to enter the university especially using the merit system. Another student leader advanced the following:

To be honest I am happy it is back because currently the merit system is open to abuse... for example at Bunda ${ }^{17}$... I do not know whether it is wrong for me to say because I am Chewa ${ }^{18}$ but you go there and the selection list is just people from the north north north you can tell from their surnames...

The respondent is happy with the reintroduction of the policy and hints at the regionalist rationale of the quota by arguing against the high percentage rate of university participation by people from the north. The student leader wonders why one of the constituent colleges of the University of Malawi, Bunda College enrols more students from the north. The respondent reveals the anger and the attitude that he/she harbours (and perhaps more nonnortherners) toward students from the north for their level of participation in the university sector. These sentiments are in line with the argument

\footnotetext{
${ }^{16}$ Nyau is a traditional cult dance for the Chewa people of the Central region of Malawi. The response also shows the derogatory view that some people have in Malawi about the Chewa people who are viewed by such people as concentrating on their traditional dance more than on school.

${ }^{17}$ Bunda College of Agriculture is a constituent college of the University of Malawi situated in the central region of the country.

18 The largest tribe in Malawi
} 
presented earlier in which historically people from the north have been viewed as "other" and as described by the respondent, you can tell from their surnames. One university manager advanced the following:

... from 2002 to about 2003 council analysed how students were being selected and it was very clear that some places were faring very bad. I will tell you this it is very unfortunate that this is being presented as if it is anti-north policy because within the north itself there are variations, and within the south and the centre there are some districts which without this new system are already doing very well beating some districts in the north. Ntcheu can compete with almost every district in the north that is why presenting it as a policy that is antiregion is I think most unfortunate.

The university manager makes the argument that it is clear that in some places students are faring badly. The manager deplores presenting the issue as antinorth as some districts such as Ntcheu in the central region can equally compete with districts in the Northern region (see appendix 12). Seeing the whole issue as anti-north seemed to be politically incorrect and proponents of the policy tried as much as possible not to associate the policy with anti-north tones so as not to be seen as regionalists.

Some proponents of the quota policy argued that the policy is vital to provide equitable access to university education in Malawi. While this view sounds reasonable, the major issue is a need for expanding access generally, other than using narrow interventionist policies for political gains as has been the tendency since the Malawi Congress Party Government in Malawi. One university manager who supported the equity argument mentioned the following:

No it is not a quota system. It is selection on equity but again that is the same problem with the access to the university. There are some districts for one reason or another where they have very good students. Others like where I come from anthu ake ndiwochita chonchi (the people do not appreciate/or work hard at school). The point is on equity to get a respectable distribution of higher education... We are waiting for a press conference or a press release from government to tell us what it is. But we are going in that direction to increase equitable access. 
As argued earlier, proponents of the policy such as this respondent were at pains to avoid calling the policy a quota system for this would associate the new policy with the one that was rescinded in 1993. In justifying the policy, the respondent refers to people from some region as anthu ake ndiwochita chonchi meaning that people are generally not hard workers or do not appreciate schooling, and, as such there is a need to give them chance to enter the university through quota system so as to achieve an equitable access to university education. Given the limited access to university education in Malawi, this view of equity is problematic as it simply translates into regionalist and patron-client mechanisms other than solving the access problem at hand. The contention is that it is more inequitable to kill the hard working spirit among the minority in the name of equity. Perhaps, what is desirable is rather to nurture and instil the hardworking spirit throughout the country for the betterment of the whole nation. Most pertinent perhaps, there is a need for proper research to determine causes of poor university participation rates in the other two regions of Malawi. Another university manager and proponent of the policy argued as follows:

If we had gone the old route (merit system) of selecting students, half of the places would have gone to one district...During that time (when quota system was first introduced) it was strictly quota when a district fails to satisfy its quota the next district could get that quota... We are just making sure that in one area we do not have a district that is not completely without students because even boreholes need to be shared. Would you have boreholes in one area? Would you have hospitals in one area? So at the best minimum there must be that distribution but we will see that at the end of the day still those that do well will continue to benefit slightly more than those that do not do well.

The respondent argues that if merit was followed in selecting university students for the University of Malawi half of the places would have gone to one district (which may not necessarily be the case, see appendix 12). As such, according to the respondent, the quota policy adheres to equity arguing that a country cannot have boreholes or hospitals in one area. However, the stand in this thesis is that real questions are not being asked such as how to meaningfully increase access without perpetuating regionalism and tribalism. Another university manager supported the policy by arguing as follows: 
... it will take a long time and before anybody has done any study to interrogate what it is that makes some places send more students to the university than others, there must be a way that inequalities are not being perpetuated.

Here, the university manager justifies the quota system on the basis that it will take a long time before tangible studies can be done to find out the reasons for the poor participation rate of some districts and regions in Malawi. Given the discussion presented earlier, no efforts have been taken by the Malawi Government to establish the real reasons why the minority, who are not politically powerful in the country, are doing better in terms of participating in university education and vice-versa. As such the policy can be seen as a mechanism to stifle the minority, the "other". Such mentalities need emancipation if the country is to achieve democratic university education management and governance. The next paragraphs show views against the equity proposals.

Views against the equity arguments presented by respondents help to show the anti-democratic nature of the policy. For example one university manager mentioned the following:

Personally I do not understand. But what I have seen in other countries where you have empowerment like in South Africa...when you have a disadvantaged group which you can identify within the state law then you can do something about it. But when that is not available it becomes difficult to understand. Of course I do not have inside information that has led to this.

The respondent makes the argument that there is a need to identify a disadvantaged group and have necessary legislation before applying policies such as the quota system of selection policy. This is important because just applying equity policies without solid foundation may bring more injustices than solve them. As such, the policy ought to have been debated using reasoned arguments so as to avoid positing it dogmatically as has been the case (Habermas, 1984, 1987). Another university manager argued as follows against the policy: 
...I think that the premises of quota are based on wrong analysis very wrong mathematical calculation... First quota system has been based on statistics that people from other districts are more than other districts so they are based on population figures... what is missing is that when they are doing population census you register where you are. It means that I will be in Lilongwe and register there... But when we are doing selection they ask you where you come from so it means the population that is listed in Lilongwe for example comprise people from several other parts. Unless we have special identities to tell the exact population so to base this on the population of districts is the number one problem. When you are doing affirmative action you assume that others have been disadvantaged for sometime but here there is no one who has been disadvantaged unless they are talking about rural versus urban... The demerit that I see in the whole issue is that it will remove the whole competitive spirit...people who were working hard will be disappointed... I do not see much merit in this thing.

While it is generally factual that the northern region is the least populated of the three regions (Malawi Government, 2008), the argument presented by the university manager makes some contribution to highlighting some of the problems concerning the implementation of the quota system. The major complication is that the population found in cities and towns does not only include people who are originally from those places. As such, in cases where there is no identification system like in Malawi it is very difficult to base selection on origin and population parameters. Further, the manager alludes to the problem of identifying disadvantaged groups and explaining in what way they are disadvantaged to warrant a policy, which has the potential to remove the competitive spirit among students. As mentioned earlier, it can be argued that removing the competitive spirit among students shall bring more harm than the proponents of the policy anticipate.

The general contention is that while issues concerning equity and access to higher education are pertinent, reasons for poor university education participation rate in some districts of Malawi are not clearly known. For example, it can be argued that if missionaries assisted northerners to develop interest in schooling, with the eventual growth of missionary work in all regions of the country, other regions could have followed suit. That this seems not to have happened suggests further research on the issue. Thus, without a 
proper identification of disadvantaged groups and providing explicit explanations why the majority who have the political power are disadvantaged within the university system, it does not suffice to argue for the quota policy. As such, the quota policy is tantamount to punishing students for their motivation and hard working academic spirit that they engender. As already argued, what is vital is to expand access to university education.

There is a need for tangible reasons and evidence that could result into well conceptualised equity policies other than interventionist policies such as the current quota policy. The policy can be viewed as a tool to support the majority for political gains within the patron-client logic. The anti-democratic nature of the quota policy is further reflected in its policy-making process discussed next.

\subsection{The quota policy-making process}

The quota policy-making process was mostly an issue between the University of Malawi and the Malawi Government. This discussion shall show that the policy-making process of the quota system of university selection followed instrumental reasoning and consequently lacked values of communicative rationality or deliberative democracy. It can be said that the policy is an example of interventionist policy model which mostly adhere to narrow political aspirations (Moja, et al., 1996). The quota-policy making process is discussed under two headings: first, the idea that like the former quota policy, this one was also a government directive and, second, that the proponents of the policy and the government machinery did not give room to dissenting views.

Data in this chapter show that although the government wanted to show that the quota policy came from the University of Malawi Council, it was a 
government directive. One university manager who attended the first meeting about the policy mentioned the following:

I managed to attend the quota meeting which was aborted and there was high tension between the senate and the council. The council wanted it to be implemented the senate thought it was not correct and that caused a lot of problems... we do not know who is behind this. I am not in a position to really say what is going on. It is an issue that is an example of government-university relationship...if it is a government directive and the government is giving you money even if you do not want, you have no voice.

From the university manager who attended the first meeting, it is clear that there was tension between the senate and the council on the reintroduction of the policy at the University of Malawi. The respondent clearly mentions that the council was interested in implementing the policy, while the senate thought it was not correct. The university manager goes further to argue that it was not known who was behind the whole issue. This shows the lack of transparency that surrounded the policy. The impression given by the university manager is that the University of Malawi Council had already endorsed the government directive, but needed to convince its senate as lack of consultation with the senate was one of the bases for rescinding the policy in 1993 as noted. The lack of transparency is also expressed by one university officer who argued as follows:

...last year the selection committees and members of senate were
invited to deliberate on this. Senate...argued that there is a need for a
wider consultation which they have not done and this time around
they have not published the directive like last year where senate was
consulted and members of selection had documents. This time around,
the directive was simply read during the selection meeting and after
the meeting other documents related to that were withdrawn, it was
done secretly...

The respondent reveals that there was a directive (see appendix 15) from the government and that the senate asked for wider consultation on the implementation of the policy. It can be argued that as a policy that was rescinded, the government should have given time for debate if it was really interested in achieving equitable access. The respondent also reveals that unlike at the first meeting, the documents pertaining to the policy were 
withdrawn from respondents at the second meeting, showing how sensitive the matter had become. Another university officer mentioned the following:

The quota system resurfaced last year there was a directive and the selection committee and deans were invited and told that there was a new selection system and we easily got wind of it that it was a quota system just prepared in another expression...This year it has come around and we still understand it as a quota system where people have to be selected depending on where they come from and not on merit ...

While the description of the policy changed to: introduction to equitable system for admitting students to public universities (see appendix 15), some university stakeholders recognised that the policy was not substantially any different from the former quota system of university selection. The name change can be said to have been an effort not to associate the new policy to the rescinded one as argued earlier and an attempt to justify the policy using recent equity discourses.

Some university managers however, wanted to show that in fact the whole policy was not a directive, but one that was thoughtfully included in the University of Malawi Strategic Plan. The thinking is that if it were a directive from government then it would have been against the law as per the 1993 High Court judgement as noted. One university manager argued as follows:

You know to begin with this was included in our strategic plan. The University of Malawi had never planned strategically until 2004 when with the assistance of donors we started to have a five year strategic plan. The issue among many was the one on widening access and that issue looked at women, people with disabilities, areas within Malawi which historically, geographically and culturally have been perpetually disadvantaged and not participating fully in higher education...

Despite clear indications that the policy was a directive, the respondent here shows that the policy was not a government directive rather it stemmed from the University of Malawi Strategic Plan. This view is generally problematic. First, if it was an issue of the University of Malawi then the policy would not have been extended to the other public tertiary institutions, which never factored the issue in their strategic plans such as Mzuzu University (Mzuzu 
University, 2006). Second, under pillar I of the said University of Malawi Strategic Plan: Teaching and Learning goal 1, the university proposes two strategic objectives that concern access to university education:

1. Increasing intake and flexibility to double intake by 2010 and

2. Ensuring affirmative action (gender, mentally and physically challenged) (The University of Malawi, 2004).

Under increasing intake and flexibility to double in take by 2010 , the strategic plan does not clearly state that the university shall adopt the quota system of university selection. Under the strategic objective two: ensuring affirmative action (gender, mentally and physically challenged) the plan mentions among other activities that it,

1. shall review admission criteria and procedures and develop a policy on the admission of the disadvantaged (gender, mentally and physically challenged as shown above).

2. implement affirmative action by increasing intake of female students at least by $30 \%$.

3. provide facilities for the mentally and physically challenged and disadvantaged.

4. provide remedial courses/tutorials and soliciting scholarships for the disadvantaged.

The University of Malawi does not explicitly refer to a quota system of university selection. Even if it would, this would be against its own university act that stipulates university selection be based on merit (The University of Malawi, 1998). The review of selection criteria concentrates on issues of gender, mentally and physically challenged students. It is in the Policy and Investment Framework however, that the issue of quota system is raised (Malawi Government, 2000a). Although this government document mentions 
government's intention to introduce a quota system on the admission of educationally disadvantaged regions, the government policy document does not explain which these regions are or the reasons they are disadvantaged or even any legislation to warrant the policy.

The Government university policy-steerage machinery did not give room to dissenting views. The quota policy of university selection attracted multiple voices from religious leaders, university students, university lecturers, the civil society and many others from which the government could have benefited in terms of debate. Notable among groups or organisations that commented on the policy are the Public Affairs Committee, a grouping of all faith groups in Malawi and the Livingstonia Synod, a Presbyterian Church operating in the Northern region of the country. Against the quota policy generally and the policy-making process, in its press statement, the Public Affairs Committee argued as follows:

1. That quota system as a policy issue could have benefitted from a proper consultative process required in a democracy.

2. That the discussion culminated into political discourse and unleashed tribal, regionalist and divisive sentiments in the country.

3. That the president's declaration amounted to top down policy approach.

4. That the president should avoid publicly making comments likely to divide Malawians (see appendix 13).

As the press statement rightly captures, the stand of the president culminated into political discourse and unleashed tribal, regionalist and divisive sentiments in the country. In this thesis, unleashing regionalist trends by the president are viewed as a quest to garner political support within the patronclient logic as mentioned earlier. 
On its part, the Livingstonia Synod in its press release generally argued that the quota policy is anti-democratic and that it should not be used as an excuse for not expanding the higher education sector in Malawi (see appendix 14).

University students generally also found the policy problematic. One student leader argued as follows:

... assuming we come up with results on Monday if the students say no to quota then we have to hunt for a lawyer to represent our views because I hear the Attorney General is supporting the government cause according to the yesterday's paper. Highly qualified lawyers from the government are ready to challenge us so we will have to find a very good lawyer to challenge these people and you know that is a process assuming that they go to court to challenge that issue on Tuesday, it means we will lose because of time factor and these people are doing these things at a faster rate and I think this is one of their strategies. For example, selection was done on Tuesday and on Wednesday they released the names of first year short listed candidates and they were interviewing them on Monday so you can see the way they are doing this...if there was not court order they would have released the names today so you can see the rate at which they want implement the policy, they do not give you room to go to court.

Students within constituent colleges of the University of Malawi were voting to have one voice either against or for the policy. As can be deduced from the respondent, the government and the council speeded up the process to implement the policy without giving room to dissenting views. The respondent shows that without an injunction that was obtained by concerned citizens against the policy, the government and the council would have implemented the policy with speed to avoid input from other stakeholders into the policy process. This is a clear example of instrumental reasoning in policy-making processes.

One university manager reasoned as follows:

I have always wondered... the president has been making comments and maybe the president is being misled. I do not know how he is being advised. Maybe some people have a hidden agenda, they pretend that they are advising the president but maybe they want to make him 
fall. But I think this is the time that many people now know his true colours...I do not think this thing will be reversed. My feeling is that the president has made his decision and he will not reverse this. So I have now come to know him as a man who once he makes a decision it is a decision...I do not know I am not a lawyer but I think he has the prerogative to say I am directing, I have issued this decree, I am the president.

The words of the university manager above explain the dismay people had from the president's remarks and his attitude toward policy-making in Malawi. The sentiments of the university manager shows how the president presented himself as, the big-man, he who decides what should be done. This is the same logic in which Banda during the dictatorial time looked at policy; he was the Ngwazi, the big-man. Similarly, Mutharika is the Ngwazi, the big-man in a democracy.

Given the arguments presented by respondents, the policy-making process was flawed. The process reveals the interventionist way of policy- steerage based on the big-man syndrome and patron-client mechanisms and is antidemocratic.

For example, as can be deduced from the data, bringing the issue to the senate seems to have been an attempt to show that unlike in 1989 and as stipulated by the University of Malawi Act, this time there was consultation between the University of Malawi Council and its senate. It seems clear that the senate opted for wider consultation, bearing in mind that the policy was rescinded in the High Court, but also because the policy was sensitive to be implemented without proper consultation. However, no room for meaningful consultation and engagement on the quota policy was given. Again as shown by the data, during the second consultative meeting, the directive was only read to the respondents and documents relating to the policy were withdrawn from them. The lack of openness on the issue presents a shortfall in the policy-making process on an issue that was sensitive to the country's education system. It can be said that, given the way the policy was propelled, the council was under 
pressure to implement a government directive. The university policy-steerage by the Malawi Government regarding the quota policy reveals the big-man syndrome among government leadership. The next discussion briefly presents the argument that the big-man syndrome in university policy-steerage has eventually affected academic freedom in Malawi.

\subsection{The big-man syndrome and academic freedom in Malawi}

While during the research respondents were positive about academic freedom, an analysis of data, as noted already, showed that the anti-democratic environment reflected by the data would be a breeding ground for challenges to academic freedom. During field research one university manager who argued that there was improved academic freedom in Malawian universities said the following:

If one sees academic freedom as the right to use one's knowledge to argue for a particular stand point without fear of censorship, there is no doubt in my mind that within the set up of the university there is total academic freedom. I have not seen since multiparty dispensation anyone being punished; I have not seen any member of our staff, losing a job on account of holding a particular view point that did not go down very well with particular political figures, unlike in the past. And you will notice that those at the your university where... is almost commenting on daily basis on political issues in the country, similarly at ... we do have... of our time who comment directly on political matters not just issues of philosophical bend but matters affecting the key political parties in the country and when they say this particular key political player is messing up you find that they are not being harassed and so on.

Another university manager augmented this by mentioning the following:

Academic freedom at this university is mainly enhanced through associations...they negotiate for what staff members would like. They can publish anything and nobody stops them. So academic freedom does exist here and it is actually encouraged that is why we encourage staff to do seminars to air out, to talk about the issues that emanate from their disciplines. 
Regarding academic freedom one staff union member held the following:

With the coming in of freedoms I think we have the freedom. I think you can publish anything and no one will stop you.

While on the surface the picture painted by the data during field research showed that academic freedom was not stifled, some events after the field work for this thesis show that the identified anti-democratic practices within universities in Malawi eventually had negative effects on academic freedom. For example, on 12 February 2011, an Associate Professor in the Department of Political and Administrative Studies was summoned by the inspector general of police for questioning over what he presented in the classroom during a Political Science lecture. This used to be the case during the dictatorial time in Malawi (Kerr \& Mapanje, 2002), where the Malawi Government had spies in university classrooms to report issues that were seen to be against the government.

In demand for academic freedom, lecturers at the University of Malawi demanded an apology from the inspector general of police and an assurance of safety in classrooms. However, supported by the Malawi president, the inspector general of police refused to apologise (see appendices 16-18). The lecturers then boycotted classes in demand of academic freedom to which the Malawi Government respondent with threats to fire lecturers, freeze salaries and eventually closed the campuses of the University of Malawi (see appendices 16-18). As is expected in the anti-democratic environment, the University Council of Malawi argued that academic freedom was not stifled (see appendix 19).

Given that academic freedom provides freedom to research and teach without outside interference (Richard \& Anderson, 1998), the Malawi Government can be said to have stifled academic freedom by interfering with what was presented in class. In this thesis, the activities of the Malawi Government are viewed to stem from the neopatrimonial attitude of presidentialism or the big- 
man syndrome in which whatever the big man decides ought to be followed. Such attitudes also show a lack of communicative rationality to solve issues using reasoned arguments. In general, the anti-democratic practices by the Malawi Government in stifling academic freedom reveal a lack of dialectical leading by the government leadership and an instrumental way of reasoning. As shall be argued in chapter 12, neopatrimonial attitudes need to be challenged to allow for a democratic university policy-steerage in Malawi.

\subsection{Conclusion}

This chapter has presented four arguments. First, that the role of the state president as chancellor of public universities in Malawi presents problems in policy-steerage as presidents tend to use neopatrimonial aspects of presidentialism and patron-client and regionalist practices in their policysteerage. Second, that consequently, university policy-steerage by the Malawi Government is interventionist and follows narrow political aspirations. The chapter has exemplified this claim by the contested quota system of university selection policy that continues the regionalist agenda in the country. Third, that university policy-steerage by the Malawi Government is woven within instrumental reasoning and lastly, that instrumental reasoning and neopatrimonial attitudes have eventually stifled academic freedom in Malawian universities. These neopatrimonial attitudes need to be challenged and contained to allow for a democratic university policy-steerage in Malawi. 


\section{CHAPTER 10}

\section{International forces in university-policy-steerage in Malawi}

\subsection{Introduction}

While chapter 6 presented an assessment of the World Bank university policysteerage in Africa based on policy debates, this chapter explores antidemocratic practices in university policy-steerage by the World Bank and partner organisations in Malawi based on data or respondents' views. Based on respondents' insights, the chapter augments the argument in this thesis that university policy-steerage by the World Bank and partner organisations follows instrumental rationality and is anti-democratic. Data from respondents have been summarised as follows: that the World Bank is a major determiner of university policy in Malawi; that the World Bank exerts its influence through the Malawi Government and that the World Bank has legitimised its influence in Malawi through the poverty reduction strategy rationale. The chapter is informative for the research, as it explains respondents' personal views about the World Bank's policy-steerage and thus, adds understanding to anti-democratic practices revealed through policy debates discussed in chapter 6.

\subsection{The World Bank as determiner of university policy in Malawi}

Respondents' views reveal that using its economic power the World Bank is a major determiner of university policy in Malawi, as this excerpt from one manager's interview reveals:

Policy within the university...is also influenced by the World Bank and you know when the World Bank coughs everybody catches the cough. Because of their economic clout they are able to engage highly qualified people who conduct research and are able to present their 
findings. I will give you an example now we are moving towards a culture of outsourcing of all non-core functions of the university... Just as I am talking to you now...the maintenance department of the university is gone through outsourcing. We are now remaining with catering. Now some of the problems that come with this is that while in the west there is ready market for these activities in Malawi we do not have a culture of outsourcing and therefore the market is not there. So we expect teething problems when you have done these things. But we end up doing them because if you do not, then you end up not getting support from the World Bank. So the World Bank is the major determiner of policy in higher education in Africa because it works in partnership with our other development partners who use the theory and the thinking of the World Bank to promote their agenda.

As presented by the respondent, the university sector does not have choice but to comply with recommendations of the World Bank for fear of losing support from the World Bank. This reveals the helplessness of the Malawi Government at the hands of the powerful World Bank revealing the powerful less-powerful relationship between the World Bank and the Malawi Government and its university sector. The respondent further argues that with its economic clout, the World Bank manages to engage highly qualified personnel to conduct research and legitimise its influence through research results, an argument that resonates with claims made by Samoff and Carrol (2004) mentioned in chapter 6. This manager identifies the outsourcing policy for non-core business of the university that the World Bank is orchestrating in public universities in Malawi, as an example of policies that are imposed. Although the manager sees the problems associated with this neoliberal policy in that there are no ready markets to support such a policy in Malawi, the Malawi Government has to comply for fear of losing the World Bank's support.

It can be said that within such a relationship policy initiatives follow instrumental use of reason in which the powerful manipulate and control the less powerful for their own gains. As argued in chapter 6, the respondent mentions that the World Bank has the capacity to influence its policy agenda through its partner organisations which means that there is no room for the 
Malawi Government to opt for help from the World Bank's partner organisations as these also follow and work within the World Bank's globalneoliberal policy logic. As argued earlier, this shows that policy initiatives from the World Bank are mechanisms for direct control (see Samoff \& Carrol, 2003, 2004a, 2004b). Another university manager shared the following reflection:

\begin{abstract}
... Sometimes donor funding comes with conditionalities. For instance if you want to do something in the Ministry of Agriculture then you need to do this to higher education. Then it just comes to us as a directive. In those circumstances yes the donor can influence policy in higher education through their funding...Donors are really emphasising on primary education more than the higher education sector. For instance one of the policies you mentioned... the Education Sector Plan, one of the issues was to outsource... and they were willing to pay the requirement package for those who will be laid off like the cooks and so on. So it is things like these that come in and we implement them. The idea of outsourcing for me is a good one it is not controversial, it is not that they are imposing something that we do not see the benefit, but there are some circumstances where we may not see the benefits but because it is their conditionality to assist another sector then you have to oblige.
\end{abstract}

The sentiments of the university manager further exemplify the relationship between the World Bank and the Malawi Government as that of the powerful versus the less powerful. In such a relationship, one sees a lack of dialectical reasoning on the part of the World Bank's leadership and a lack of engaging communicatively using reasoned arguments in which there is mutual respect and reciprocity of ideas without employing force (see Habermas, 1984, 1987). These findings resonate with claims that "values that national systems of education now promote through policy are no longer determined wholly by policy actors within the nation-state, but are forged through a range of complex processes that occur in transnational and globally net-worked spaces"(Rizvi \& Lingard, 2010, p. 22). Supporting the idea that the World Bank is the main determiner of university policy in Malawi, in the following excerpt, one respondent questioned the power imbalance:

...we are in extreme subjection of the IMF, World Bank and bilateral partners. They have heavy influence on our policy. In other words they are the ones that make our policy, we just endorse... For example the budget that we have been making in the past years it is much more of a reflection of the interest of the World Bank and IMF... There is too much pressure and they are using money as pone. The other aspect is 
that...our policymakers... go into discussion and dialogue ill prepared. Why I say that is that in most cases these institutions as they come in our countries, they are well equipped, they get information from here, analyse it and when discussions and dialogue are taking place we are much more of recipients other than actors into that process...

The respondent depicts Malawi as being in a position of extreme subjection in relation to international finance and aid organisations. When meeting organisations such as the World Bank, policymakers from Malawi are ill prepared to challenge some of the ideas presented by such organisations. The respondent avers that this reduces policymakers from Malawi to simple recipients of external policy. This extreme subjection arises from a lack of respect on the Malawian policymakers by the international finance institutions. Commenting on the relationship, one respondent lamented:

\begin{abstract}
I am coming to World Bank and IMF as external factor, I would say I have never seen a country where foreigners...even these bilateral and multilaterals can just come and do whatever they want and get away with it. One of it is that our ability as Malawians in general is that we are too submissive. The question of engagement and putting our feet down is not there so that also brings in a culture that is damaging because our people are not aggressive or assertive to say no to the World Bank or the IMF or the DFID ${ }^{19}$.
\end{abstract}

The respondent argues that in Malawi there is a submissive culture that leads to accepting organisations like the World Bank to do anything that they propose. Thus, the major problem in terms of external influence is that the World Bank has become too powerful in its influence of policy initiatives in Malawi generally, and, as such, its policy initiatives including those of the university sector can be said to be manipulative to fit the global-neoliberal agenda. This view is supported by another university manager whose reflections are recorded as follows:

It [the World Bank] ${ }^{20}$ has impacted on Malawi in a very bad way. To begin with during the UDF 21 era the World Bank wrongly in retrospect

\footnotetext{
${ }^{19}$ DFID stands for Department for International Development. It is a department for British Aid.

20 My addition in parenthesis

21 UDF stands for United Democratic Front, one of the political parties in Malawi which ruled the country under Dr. Bakili Muluzi from 1994-2004
} 
was claiming that if we invest in primary education the social returns are greater than in secondary and tertiary education. But you know what they did not know is that education is a continuum that if you have poor primary education it will have impact on secondary and university. Similarly, if you do not have strong secondary and tertiary education the teachers from TTCs 22 will not be of high quality and will not teach primary school students well. But if you promote all the sectors equally well, then you are assured of a sound education so what we were denied by the policy of the World Bank through the Malawi Government was a sound education.

The respondent holds the view that by insisting on investing in basic education at the expense of secondary and higher education sectors, the World Bank denied the country a sound education system. As already shown in chapter 6, by using the rate of return analysis that assesses the public/private cost of education and their gains, the World Bank argued that basic education was more likely to contribute to poverty alleviation than the university sector (see Bloom, et al., 2006; Bloom \& Rosovsky, 2007; Brock-Utne, 1996). While there was a need to simultaneously support the university sector, the World Bank proposed cuts to the sector in Africa. As noted, the Malawi Government had no choice but to comply with the demands and prescriptions of the World Bank in the powerful less-powerful relationship and concentrated on the basic education. Reflecting a change of policy by the World Bank, one public officer said the following:

I think in the past World Bank focussed on basic education using some theories they felt that a country would develop if they concentrate on basic education. But they have now realised that no country has developed by focussing on basic education and there is a change of heart as they say there is enough emphasis on higher education and yes in that respect they have also contributed in our policy direction because there is funding for higher education like construction of lecture theatre, upgrading of infrastructure in the university, the expansion of Mzuzu there a lot of things that are happening with the World Bank. That is recognition about the importance of higher education.

Again resonating with literature generally as shown in chapter 6, the respondent mentions that there is a change of heart by the World Bank, as it

\footnotetext{
${ }^{22}$ TTC stands for Teachers Training College
} 
now wants to invest in the university sector again. As already shown in chapter 6, the World Bank policy started to indicate signs of support for the higher education sector within the knowledge economy discourse. The respondent cites the infrastructure development that the World Bank is rendering to public universities in Malawi.

As noted in chapter 6 , there are implications for the renewed interest of the World Bank to support the university sector in Africa. First, using the knowledge economy discourse, the World Bank has found another opportunity to formulate policies for Africa. Second, the discourse is used to support the World Banks' contention that university education in Africa should align to the labour market impeding critical pedagogies generally. As noted, this is viewed within this research, as manipulative and adhering to instrumental rationality. The next discussion aims at showing that the World Bank's influence happens at the Malawi Government level.

\subsection{The World Bank's influence through the Malawi Government}

Respondents' views reveal that the World Bank steers university policy in Malawi through the Malawian government and that the level of direct engagement with the university personnel is limited. The excerpt from one university manager's interview goes as follows:

\footnotetext{
The challenge is that we are not a direct spokesperson with the World Bank. We participate as partisan of the government and when the government is actually meeting the donor we are not there and I would have thought that when the government meets the donor the representation of our universities should also be present.
}

The respondent's argument shows that as a concerned sector, the university needs to be represented when the World Bank meets the Malawi government on university education issues. This lack of representation by the university sector is problematic, given the fact that the World Bank is generally 
represented by experts who can easily convince the government to follow its prescriptions as noted. Besides, the government may be interested in loans to support its political agenda without really looking at the implications for the future, hence the need for professional advice. Another university manager presented the following:

...the international community will influence policy through
government and through matters like tuition fees apart from that not
much. Actually what we call funding from World Bank should be
understood as money from government because World Bank does not
give money to the universities. World Bank gives grants to the
government, will give loan to government and government will use it
for higher education, secondary education, and primary education and
so on. Truly thinking it is not money from the World Bank it is money
from the government but government is being assisted through loans
or grants by the World Bank

The argument presented is that the World Bank gives loans and grants to the government, which in turn channels that money to the different education sectors. The sentiments of the manager augment the idea that the influence of the World Bank is at government level. Given that the Malawi Government largely depends on external financial support (Claussen, Amis, Delay, \& McGrawth, 2006), chances of resisting university policy changes that are tied to money are very minimal. Influencing policy through government gives chance to the World Bank to manipulate policy at the highest level of policymaking. Another university manager assessed the World Bank's influence as follows:

...in my experience the donor's influence is not a force of good. Implementation is frequently far too slow, with many so-called 'experts' reaping substantial consultancy fees for little output. The wider local influence within Malawi is largely confined to the political domain. Professionals play a small part but really should have a greater role.

The respondent argues that in general the influence of the donor is not a force of good. The manager cites slow implementation of the projects, the reaping of money by their experts and that policy is generally through the government in which professionals play a very small part. As argued in chapter 6, the World Bank has begun to fund through sector-wide mechanisms as opposed to 
discrete projects. Within sector-wide approaches university education is just part of the broader anti-poverty strategy woven within the global-neoliberalorthodoxy alluded to earlier (Samoff \& Carrol, 2004a). In this way, there is a general lack of direct and discrete funding for need prioritised by universities. Another public officer talked about the following:

\begin{abstract}
Government should not think that...only civil servants...can talk and engage on behalf of the government. This is a very narrow way of looking at things because people within the private sector who are knowledgeable should be part of the delegation. But our policymakers have taken it that government is only civil servants, I think ... in terms of where there are critical agenda in a country most of our experienced knowledgeable people should be used.
\end{abstract}

The respondent echoes the need for proper representation when government talks to organisations such as the World Bank. As argued earlier in this thesis, lack of proper representation helps the World Bank to propel its policy agenda within the realms of instrumental reasoning other than communicative rationality. The next section shows how the World Bank has legitimised its influence in Malawi through the poverty reduction discourse as argued by respondents.

\title{
10.4. The Poverty Reduction Strategy Paper and the university
}

Based on respondents' views, the general argument presented here is that the Poverty Reduction Strategy Paper process facilitated by the World Bank in African countries including in Malawi, has legitimised the World Bank's influence in Malawi. The legitimated influence affects all the sectors including the university. The discussion further shows that following the Poverty Reduction Strategy Paper's rationale, university education is not given primacy. Reflecting on the Poverty Reduction Strategy Paper process, one respondent said the following:

My experience in Poverty Reduction Strategy Paper and also other policies like the Vision 2020 that we had is that yes the government has attempted in terms of making consultations however one would 
have liked much more in terms of engagement of our people down there...I recall the Poverty Reduction Strategy Paper was much more of a blue print because if you look at it, at that time there was just a wave in all African countries... the IMF, World Bank pushing. I am not saying that pushing some of those policies is wrong but what I am saying is that a policy is there to make an intervention, finding solutions to the problems that people are faced with.

The respondent clearly argues that the Poverty Reduction Strategy Paper process was just a wave in all African countries by the International Monetary Fund and the World Bank. It can be argued, thus, that while participatory mechanisms were employed, the discussions proceeded following specifications of the World Bank and its partner organisations in an effort to generalise its policy-steerage in Africa (see Fraser, 2005; Samoff \& Carrol, 2003, 2004a, 2004b). One public officer held the following:

\begin{abstract}
Policies start from the grass root level and they evolve as it were. When it comes to us it is a matter of putting that policy into context to make sure it is in line with the Malawi Growth and Development Strategy... We make sure that the policy has to evolve from particular sector... and then finally we also put our work on it to make sure that it is aligned to the Malawi Growth and Development Strategy...we need to add three additional areas including education. This year we are starting to review it and we start developing a successor strategy to the Malawi Growth and Development Strategy.
\end{abstract}

The respondent argues that policies from different sectors (including the university sector) need to be compatible with the Malawi Growth and Development Strategy. As noted, the Malawi Growth and Development Strategy has been developed from the Poverty Reduction Strategy Paper and as a policy document the education sector is required to align its policies to it. The Ministry of Development Planning and Cooperation is endowed with mandate to coordinate the implementation of the Malawi Growth and Development Strategy.

The Malawi Poverty Reduction Strategy was launched in 2002 to translate long term strategy of the Vision 2020 policy document into medium term action plans (Malawi Government, 2006a). The goal was to achieve sustainable poverty reduction through the empowerment of the poor through strategic pillars: sustainable pro-poor growth, human capital development, improving 
the quality of life of the most vulnerable and governance. In addition it had four cross cutting issues namely HIV and AIDS, gender, environment and Science and Technology. The Poverty Reduction Strategy Paper was reviewed in 2005 and its findings informed the strategic direction of the Malawi Growth and Development Strategy.

Following on the Malawi Poverty Reduction Strategy Paper, the key priority areas for the Malawi Growth and Development Strategy are: Agriculture and Food Security; Irrigation and Water Development; Transport Infrastructure Development; Energy Generation and Supply; Integrated Rural Development and Prevention and Management of Nutritional Disorders, HIV and AIDS. These key priority areas were further explained through themes. The Malawi Growth and Development Strategy has also aligned its focus to the Millennium Development Goals. While Education is not listed as a priority area, it is mentioned as a sub theme of social development. On education, the sub-theme states the following:

In the education sector, emphasis will be on equipping students, especially at primary school level with basic knowledge and skills to enable them function as competent and productive citizens; to provide academic basis for gainful employment in the informal, private and public sectors; and to produce high quality professionals with relevant knowledge...(Malawi Government, 2006a, p. xxii).

The university education sector in Malawi Growth and Development Strategy is not given any primacy, where it is mentioned, it is only in passing such as on section 2.5 (Millennium Development Goals) which on Education states the following:

The Malawi Growth and Development Strategy seeks to increase enrolment to $95 \%$ and reduce the dropout rate to 5 percent by 2012 . At primary school level it is expected that there will be substantial reduction in absenteeism, repetition and dropout rates and high quality and relevant education. At secondary and tertiary levels it is expected that there will be increased access and improved quality and relevant education for both sexes and people with special needs (Malawi Government, 2006a, p. 5). 
Given the World Bank Poverty Reduction Strategy Paper rationale, it is clear that the Malawi Government was expected to stress the basic education component that the World Bank supports at the expense of the university sector. The priority areas cited in the Malawi Growth and Development Strategy are generally those that the World Bank prioritises and, thus, the participatory mechanisms manipulated respondents to think in the direction and specification set by the World Bank. Another university manager reflected as follows:

Usually the World Bank will come to a country and look at country policies and which sectors they would want to support and in discussion with government raise up their interests to support critical areas. The World Bank has contributed in terms of funding which were used to come up with the document [NESP] ${ }^{23}$ and also sometimes they identify expertise to assist us...these are home grown ideas which need some kind of stimulus to take them forward... We call the Malawi Growth and Development Strategy a home grown policy.

Although the respondent depicts the Malawi Growth and Development Strategy as a home grown policy, it is clear that it follows the World Bank's rationale. Another public officer said the following:

What we have in Malawi is that as an umbrella policy, the long term policy is the Vision 2020 whereby we have the aspirations, the dreams of the people...They want Malawi to be a middle income country and all those issues by 2020. And below that we have different strategies which are short to medium term and at the moment the medium term strategy is the MGDS. It is a vehicle for implementing the Vision $2020 \ldots$ and below that we have various sectoral policies as well, Agriculture has its own policy, Education its own policy, Health has its own policy and others. And these sectoral policies are supposed to be vehicles as well for implementing the MGDS.

The respondent shows how the country in general is expected to align its different policy initiatives to the Malawi Growth and Development Strategy, which is generally done at the Ministry of Development Planning and Cooperation. The Malawi Growth and Development Strategy in this way provides funding base for policy initiatives. As argued in chapter 6, this is a clear example of how education debates have been concentrated in finance or

${ }^{23}$ My addition in parenthesis 
planning departments in Africa, which tend to favour the neoliberal stances of the World Bank (see Samoff \& Carrol, 2003, 2004a, 2004b). In this way the World Bank can easily exert its influence and its agenda. Another public officer mentioned the following:

I would say that for the sake of Malawi I think gone are the days whereby the donor is calling and we are followers. We are little bit lucky ...I know this has been the case in the past that donors could dictate from their own capitals out there but I have seen that of late the government is ...clearly defining its area of interest as far as the education is concerned...This has been manifested through the PIF for the Ministry of Education and now they have also developed the NESP which have defined to a certain extent what we want to implement... in this particular sector. And we are allowing donors to come and marry in that particular programme. In addition to that within the education sector we are also trying to develop a sector-wide approach whereby we intend to clearly develop our own plans in strategic manner and also allow donors to come in a coordinated manner and buy into that.

While the respondent is clear in terms of how the policies such as the Policy and Investment Framework and National Education Sector Plan in education have come about, what is problematic is that the rationale for these policies generally follows the directions and specifications of the World Bank as argued earlier. More so, the initiatives were funded by the World Bank (Malawi Government, 2006b).

The Poverty Reduction Strategy Paper rationale has helped to legitimise the power of the World Bank in education policy in Malawi and Africa generally. Fraser (2005) sees the Poverty Reduction rhetoric as a total extension of the global-neoliberal agenda seeking legitimation through poverty discourses. Following Critical Theory perspective as used in this thesis, the Poverty Reduction Strategy Paper rationale follows instrumental rationality that seeks to control. Given the legitimised power of the World Bank, the direction of the university sector in Malawi will technically depend on the direction given by the World Bank unless there is mutual respect in university policy-making following communicative rationality. 


\subsection{Conclusion}

Based on respondents' views, this chapter has shown that the World Bank has much influence on university policy-steerage in Malawi because of its economic clout. Giving an example of the outsourcing policy, the chapter shows that in most cases, Malawi as a country has no choice or power to reject prescriptions from the powerful World Bank. Further, that the World Bank works through the Malawi Government with little room for professionals such as those involved in the university to contribute to university policyformulation which perpetuates a lack of critical engagement in policy-making. The chapter contends that the World Bank has used the Poverty Reduction Strategy Paper rationale to legitimise its power in Malawi. Like in chapter 6, the general argument presented is that the World Bank's university policysteerage in Malawi is conceived within the realms of instrumental rationality aimed at social control within the global-neoliberal logic, and, is as such, antidemocratic. The chapter has illuminated respondents' personal views about the World Bank's policy-steerage and thus, adds to understanding antidemocratic practices revealed through policy debates discussed in chapter 6 . 


\section{CHAPTER 11}

\section{Respondents' views on improving the management and governance of the university sector in Malawi}

\section{1. Introduction}

One of the objectives of this thesis was to identify ways to bring about change within the university sector in Malawi. This chapter presents respondents' views on ways to improve the management and governance of the sector. It is helpful to note that suggestions by respondents do not necessarily adhere to lenses of Critical Theory as they certainly do not work within this paradigm. However, where necessary, their views are assessed within the lenses of Critical Theory. Respondents' views however, contribute to the development of a theory of university management and governance based on dialectical reasoning and communicative rationality presented in chapter 12 .

Respondents presented varied views that have been summarised as follows: those that propose university level changes; those that propose practical changes at national policy-steerage level and those that propose changes at state policy-steerage level. The data were presented as outlined above. It thus, begins by university level changes as suggested by respondents.

\subsection{University level changes}

At university level major changes proposed by respondents were as follows: a need for participatory administration/governance and collaborative research. These issues were viewed by respondents as important in democratising the 
management and governance of the university sector in Malawi. One university manager said the following:

I think most of the changes should be within. To get staff to take on responsibility. Once they understand their responsibility they will be able to contribute positively to the governance of the university because you see the demands are quite huge from the government side.

The respondent argues for a need for members of staff to know their responsibilities in order to contribute positively to the governance of the university. However, as argued in chapter 8, knowing responsibilities alone is not enough when the big-man syndrome counters efforts by academics to participate in governance effectively. As such, a need to rationalise neopatrimonial attitudes that permeate university governance becomes pertinent. Another university manager has the following reflection:

Well I think for me I would... rather talk about what I am already doing...one of the things is that we make decisions by consulting widely there are no decisions that are taken without consulting. We consult all members or their representatives and they give their views and we circulate it to all members of staff and we have got a server list where if we send a memo they read it from wherever they are whether they are in Australia, New Zealand, Canada and they give us feedback and then that is how we have operated and that is one thing.

The respondent knows that in some universities, there are consultative ways of decision-making. This is important for improving the management and governance of the university sector in Malawi. However, it is helpful to realise that consultation demands more than soliciting stakeholders' views as advanced by the respondent. To contribute to democratic affair, consultation needs to be accompanied by a listening spirit and one that entails prioritising the use of the force of reason as opposed to force of coercion (Carr \& Kemmis, 1986; Habermas, 1984, 1987). One staff union leader averred as follows:

First and foremost management has to learn to listen to people. Do not shut them out. They should understand that most of staff here does not have a strong academic background because they did not work for the universities, they were in management elsewhere. They came here old and are in transition. Now the young members of staff need to be sent to school quicker so that when they go they can come and assist the 
university. The other one is that academic research needs to be very well supported.

A listening spirit is vital in the management of institutions. As argued earlier, a listening spirit is one of the tenets of democratic governance (see Habermas, 1984, 1987). It can be argued that the respondent is against the big-man syndrome in management, which counters democratic governance in Malawian universities, as already noted. One university manager said the following:

We have made some changes to the [university] ${ }^{24}$ act so that we make sure that people who are getting into currently...are not the councillors and at the same time senators. Now, to start with, you have the entire management in council and the same people will be implementing the policy. All academic matters being discussed by council first of all go to senate and senate sends that to management to bring to council. Now management are the principals, and the principals are councillors and the principals are senators so they send issues to management, then to council to approve but they are the same people doing that. So we want to change this.

The respondent points to the idea that they have made some changes to their university act so that it is not the same people taking decisions in council, senate and management. Having the same people making decisions at council and senate has the potential of perpetuating the big-man syndrome, as the same people can easily make decisions that support their own personal agendas without checks and balances. As such, the suggested change is welcome as it shall contribute to reducing instrumental reasoning and the bigman syndrome in the management and governance of universities.

Some respondents argued for collaborative research. One student leader held the following views:

I would basically suggest that in conjunction with the academic members and students there should be research which should be conducted. I see this to be very common in other universities. The university should also involve students in decision-making more than

24 My addition in parenthesis 
what is happening now. The students should actually be incorporated in all committees of the university.

To improve university management and governance, the respondent argues for a need for joint research between students and academics. Joint research would be helpful in enhancing the collaboration of stakeholders such as students and academics. This is key in that teaching and learning in the university within democratic parameters (as viewed within Critical Theory), ought to be a reflective and respectful experience where learners and academics are co-producers of knowledge (Waghid, 2006). The respondent further mentions a need for involving students in the governance of the university as an important tenet for achieving democratic governance, a view that is pertinent in Malawian universities as argued in chapter 8.

\subsection{National policy changes}

Respondents suggested several changes pertaining to national policy issues. Their views have been grouped as follows: a need for the National Council for Higher Education to be established; a need for changes in national university curricula and related issues; a need for the Malawi Government to support private universities; a need for engaging the civil society in policy praxis; a need for a strong national student union and a need for widening access to university education. While some of the suggestions can be said to be technical, most of them relate to creating an enabling environment that can contribute to democratic management and governance of university education in Malawi. One university manager mentioned the following:

Certainly I would encourage government that it should go ahead to get the National Council for Higher Education which will serve as a bridge so that in terms of us championing government policy we will be better placed with the facilitation of the council. Secondly, the council will help in terms of auditing our activities so that we do not do things that we enjoy but things that are necessary. At the moment that is not being done in a systematic manner. 
The respondent argues for the establishment of the National Council for Higher Education, which is it hoped, will serve as a bridge to facilitate government policy. As shown in chapter 7, it is important to note that discourses that refer to councils for higher education have basically stemmed from the neoliberal agenda and need to be treated cautiously within the university sector. In order to improve the management and governance of the university sector, the respondent hopes that the council will help in auditing activities of the university in a systematic way. However, the success of the National Council for Higher Education will depend on how independent the body shall be. If, for example, the body gets caught up within the neopatrimonial logic it shall not be able to effectively contribute to the democratic management and governance of university education in Malawi. Another university manager answered as follows:

... the vision I have is that the National Council for Higher Education will be independent as we intend it to be and powerful therefore the council will be like a referee. It has no invested interest, university vs. government discussions you are all interested parties so council will probably move things.

The respondent hopes that the National Council for Higher Education will be independent in facilitating policy for the university sector by bringing about democratic ways of policy praxis. However as already alluded to earlier, this shall depend on the activities of the Malawi Government in its policy-steerage, which as revealed in this thesis, are interventionist and caught up with neopatrimonial aspects of big-man syndrome and patron-client. One university manager held the following views:

The one major policy that has come up now is the policy that we should have the Malawi Council for Higher Education, which is a common entity in many African countries. The council would like to set standards at the national development of education... This is irrespective of whether it is a national university or a private university. This was missing and therefore this umbrella...will help not only the national university but the private as well in a way of keeping the standards, accreditation, infrastructure, industry and relevance... Private universities shall be assured that whatever programmes they are putting up can compare with any...we also like it because the council will be higher than even the national universities and the bench marks will be set for everyone irrespective of who you are 
whether national or private. It is something which all of us will benefit from.

The respondent welcomes the National Council for Higher Education and hopes that the private university sector will also benefit in terms of keeping standards, accreditation and deal with issues of the relevance of university education. Given problems with access to higher education in Malawi discussed in chapter 4, a proper collaboration between the Malawi Government and the private university sector is vital, as this has the potential to improve access to university education and hopefully help prevent interventionist policies, such as the quota system of university selection.

Some respondents were interested in changes in national university curricula and related capacity building issues. One university manager said the following:

...the second is to look at the programmes and see how we can make them more relevant to society. We have not done much in terms of outreach of most of our programmes. Of course people see our teachers going to school offering services to society and people understand what we are doing.

The respondent argues for a need to work on the relevance of the courses offered in universities. While it is important for universities to be relevant to societal needs, the idea of relevance is debatable and it ought to move beyond technicist conceptions, such as those that only support education for neoliberal or economic gains at the expense of a vibrant citizenship education, as argued in chapter 7. Another university manager averred as follows:

...we need to move more to Science and Technology through some of the programmes that we have started. Some are unique in a certain way and we can use them to advance issues of Science and Technology. I will mention for instance renewable energy, forestry the whole natural resources with the addition of water resources management we seem to have covered the whole sweep, so the next question will be what value can we add.

The respondent argues for the need to move toward strengthening Science and Technology in the university curriculum. Again although this is important, its 
success shall depend on whether universities shall be able to achieve democratic governance to create an enabling environment for the running of universities. Hopefully, strengthening Science and Technology should not be at the expense of citizenship education in Malawian universities that is pertinent to curb neopatrimonial attitudes. Another respondent mentioned the following:

\begin{abstract}
...we need to have a system which is building a society and makes it move. A system should go beyond training people in white collar jobs only but citizens that can assist in advancing the national agenda because we cannot develop if we do not produce. We should be productive as a people but in the current situation we are far from there...
\end{abstract}

The respondent supports a curriculum that will help to build the national agenda of the country and one that shall allow the country to produce. A sound, well balanced education is healthy for Malawi, but shall require great emphasis on working together, rather than adhering to big-man syndrome, which hinders communicative rationality. One public officer said the following:

We have a lot of plans in higher education. One, we recognise the fact that most of university departments are manned by junior staff. The percentage of staff associates in our universities is quite big. We want to make sure that these get minimum of masters degree and also we need a number of PhDs to do research and carry the junior staff in the process training them. We want to recruit more staff and ensure we retain the staff by having good salaries and other motivational things so that they do not run away... We want to have more masters students and increase the production. We want to ensure that there is equity in the universities in terms of recruitment. We want to ensure that there are more students enrolled and the issue of bed space determining the number of students should stop. We have actually instructed the universities to outsource the cafeteria and other services so that we have more students. We must outsource a number of things so that we can concentrate on core business of the university. We do not want the university to be chasing food that is not our core business...

The respondent mentions a need for building capacity for universities and for increasing the quality of lecturers, equity in university recruitment, outsourcing policy among others. The sentiments of the respondent reveal how the neoliberal and new-managerialism discourse permeate the university system. The issues discussed by the respondent are relevant in the growth of 
universities in Malawi. While this growth is pertinent, there is a need to develop democratic practices in policy-steerage simultaneously.

Some respondents urged the Malawi Government to support private universities. For example, commenting on whether the Malawi Government has created an enabling environment for the growth of private universities, one university manager talk about the following:

I would say yes and no. Yes because they have set up policies and recognise the role of the private institution...in human development. Certainly that is there, because they have even set up accreditation body to really assist the private sector. But a no in the sense that the government has not come forth with aid or grant or financial systems like it used to be at secondary school level where they would give salaries of teachers or give grants for running the institutions...We are not asking for that at this particular time. We are saying, government give... to us so we can train for you. We can develop their staff, for example we have our social work programme now the government has no institution of higher learning in this country training social workers. Chancellor College is just starting this time and they are training more in the masters level. So many districts in this country are staffed by social workers but these workers are not trained, they may have gone to Magomero you know but that is just a certificate so we would like to upgrade them here and in so doing we are not begging but we are saying we have the capacity to train their personnel. And this is what we are looking for not just money because there will be strings attached.

The respondent mentions that the government needs to come forth with a mechanism to assist private universities as it did with primary and secondary schools which were grant aided where it would give salaries of teachers or grants for running the institutions. The respondent acknowledges that the government has set up policies and recognise the role the private institutions play in human development in Malawi. Further, the respondent quests for a kind of collaboration between private universities and the government so that the concerned private university could offer training to government social workers. A need for the government to support the growth of private universities is pertinent, given that it is one way of widening access to university education that is most crucial in the country at the moment. As such, the collaboration between the Malawi Government and private 
universities mentioned by the respondent is most welcome. Another university manager responded as follows:

I would like to see government supporting these private universities. For example... I was happy that the president is supporting us with a 100 bed girls' hostel. Now we have received about 43 million kwacha to start with the project. So we appreciate that kind of support and also we do appreciate this peace and tranquillity that is in Malawi because without it then you cannot have a university. We need to have more support from the government and we have been saying to the government that we are training Malawians and these Malawians are going to work here in Malawi. And these will contribute immensely to the development of the country and now if the government is giving scholarships to students in public universities, they should do the same to our students because these have come to us because they prefer to be trained in a Christian university after what they see in... colleges where discipline is going down...They just decide to come here or they have a special reason so let the students be given equal opportunity in form of bursaries and so on. By the end of the day whether you attend a Christian university or not you are a Malawian and should get equal support.

The respondent thanks the state president for supporting the private university with infrastructure development. While this is a good gesture, there could be better mechanism to support in this area. For example, it would be better for the support to come from the government other than the state president for this encourages the big-man syndrome. Further, if the support comes from the government per se, proper mechanisms could be put in place for sustained support. The suggestion for the government to start granting loans to private university students is a welcome idea and one that has potential to contribute to increasing the much needed access to university education in the country, as most needy students will get support for their studies.

Some respondents mentioned a need for the civil society to play a role in policy-making. One respondent mentioned the following:

Civil society has got a role to play. Their main role is to complement government, to help government in terms of policy formulation, to advise government on all those issues. I know it is unfortunate in Southern Africa including Malawi most of our civil society are not that aggressive unlike for instance in West Africa where they are fully 
developed. Malawian civil society is also coming up slowly and I guess their role is also critical... I know and do know that government attaches a lot of importance to civil society. It is unfortunate that for a long time in Malawi, government and civil society used to see each other as competing kind of organisations with a lot of mistrust but I see that civil society now... are mature and responsible, criticising where it is due and not necessarily criticising on anything. I guess it is a process to develop since the civil society is a very big plus to government because they see other things that we cannot see. And they can ably assist us...

The respondent argues for a vibrant civil society that could complement government's efforts in university education policy. The respondent mentions that it is important for the Malawi Government to benefit from the civil society in terms of policy formulation. The enhanced role of the civil society is pertinent, as it would encourage democratic policy-making for the university sector. However as already mentioned, such efforts shall depend of on the listening spirit on the part of the government. Another respondent said the following:

My view is that it is a question of identifying a mechanism through which policy dialogue can start and take place. I think NGOs that deal with policy issues could take it up or independent policy think tank as it were could be established to look at the whole issue of policy cycle and also mobilise and harmonise experts. Then papers could be commissioned, policy research papers analysed, published and disseminated. So that may be on an annual basis that forum could meet where... Consensus could be achieved...and action plan could be developed and government could commit itself to say we are going to do such such things. Where government is not committing itself, civil society can engage in advocacy to force government to be accountable.

The respondent sees the role of the civil society as complementary to government services. The civil society in this way could constitute a form of public sphere (Habermas, 1991) that helps government see and solve problems in higher education. The role played by the civil society would contribute greatly to deliberative mechanisms in university education policymaking in Malawi especially in rationalising (in a Habermasian sense) neopatrimonial attitudes (see Habermas, 1984, 1987). Another respondent said the following: 
The other aspect is the access to information bill because in absence of the Information Act people who want to engage government will face challenges in terms of release of information... when you are working in policy, policies are made in governmental structures and the implementation tool is the government structure...institutions can create good rapport but...you get technicians who can deny people information on the basis of confidentiality even on things that are basic. I have been to government offices and 99\% of things that they are hiding are basic, they are not supposed to hide, why they should hide to a citizen who is part of and parcel of that information. Like in South Africa they have Access to Information Act which spells out how citizens would access information from government...In case that government is not releasing information, what action should be taken.

The respondent argues for a need for an Access to Information Act to facilitate the flow of information especially in policy related issues. Access to information is a democratic endeavour and one that can assist all stakeholders in policy including that of university education. Given the problems of access to information mentioned by the respondent, an Information Act could be helpful in making sure that information is available to the public, including the civil society so that stakeholders can contribute to university policy-making in informed ways in Malawi.

Some suggested a strong national students' union that could assist in channelling students' voice. One student leader mentioned the following:

... We do not have a strong student union where issues could be followed through. That could be an entry point because frameworks are already there. And also some institutions can work in terms of networking because members already have skills and also students would actually do very good advocacy. The question is trying to harmonise, sell ideas to them and they can be assisted by people who could help in terms of programme setting.

Supporting the idea, another student leader said the following:

Prior to coming here I was with... so honestly we need a student union platform in the country that could represent all the universities and the smaller colleges not just the University of Malawi one. We need a platform where we are consulted when they are doing policy issues so that we have a channel through which our voice could be heard. 
The student body would constitute a kind of public sphere (see Habermas, 1991) that would help in debating university education policies and their formulation processes. As already alluded to, this is imperative in fostering democratic university policy-steerage within the university sector. As noted, in Habermasian sense, attempts that adhere to deliberative democracy are crucial in rationalising the taken-for-granted attitudes generally.

Some suggested a need for widening access to university education. One university manager argued as follows:

My own feeling is that we should do away with this thing of residential and non residential students because what happens is that the residential students will pay K25 000 a year and have a scholarship from government while the non residential will pay K100 000 a year and find own accommodation which I think is not fair. In fact the non residential issue is not their problem at all, it is the university which is at fault they did not have enough space. With the outsourcing of the kitchen I would think that to be fair the tax payer should pay the tuition fee for everybody... like last year we had 900 on full scholarship and 500 who came as non residential so it was 1400 . So the 900 were admitted based on bed space and the 500 by asking the faculties and departments how many more can you take. So if that is the case my own feeling is that let the government pay for everybody's tuition fee and the selection should be based on the classroom size. In this case the answer would have been 1400 and ask them to apply for residence separately and government can then decide to give scholarship to those who are needy. But now when all of them are Malawians and you have sat for the same examinations and both of you have passed and because one got 62 while the other 61 should pay 100000 is not on.

The respondent argues that to widen access, selection policy based on bed space should be abandoned. This is in line with recommendations advanced in chapter 4 . In this case all students who qualify should be given places based on classroom size. As such, government should pay tuition fees for all those that have been selected, while the students should cater for their own accommodation and food. This means that the government then could give scholarships to the needy, which makes more sense than the quota system policy in university selection in that it is neither regionalist nor manipulative. However, the major problem lies on the criteria of identifying the needy, as this has already been contested since government started providing loans to 
university students (Hayward \& Ncayiyana, 2006). Another university manager mentioned the following:

I think I would like to broaden the access like everyone does for opportunities to a wider number of people without diluting standards and that means to be innovative in the ways of recruiting students, we need to invest a lot in secondary education. Secondary education is very important, we used to have excellent state secondary schools but they have allowed it to wither to some extent because of the thinking to promote primary education. Secondary education is absolutely compulsory because unless you have well schooled secondary students to the level of $\mathrm{O}$ level and better you will not have candidates who will take advantage of the tertiary education. So my view is investment in secondary education and raising of status of those educators in other words to see clear awards, financial reward for a community teacher. They are very important to encouraging students. So those are the issues that I would concentrate on as a government to make improvements.

The respondent argues for a need of a sound education system that supports all sectors: primary, secondary and tertiary. In this case, the respondent feels access to university will be improved with quality students. The respondent argues that standards at secondary school have been left to wither due to the focus on primary education. The respondent argues for better remuneration for community day teachers so that they can better assist in students' achievement for the tertiary education sector.

\subsection{State university policy-steerage}

Respondents who touched on state-steerage of university policy were mostly interested in the autonomy of the universities. One university manager posited the following:

In terms of the way we run as the management of a university... I have already mentioned interference from government and therefore the views of the people at university level should matter at university level. We need to change the Act so that if council decides something should not say because we are a policy-making body but policy should be participative, use the brains that are around and so on... But again... university council you know everyone there is appointed by the president so no one would oppose what the government wanted. We 
need some radical thinking and sometimes it may be that NGO supported by donors but most of them are for basic education and we need them for higher education. If donors can also fund NGOs it will help. We need bodies that could engage the university.

The respondent makes the argument for participative policy-making at council level. The respondent mentions the problem public universities face in that council members are generally appointed by the president who has power over them. Given the neopatrimonial attitudes discussed earlier, it becomes very difficult for the council to be independent of the big-man syndrome of the chancellor and the government. The respondent argues that the sector would benefit from the engagement of Non Governmental Organisations (NGOs). As noted, this would be a welcome public sphere. The respondent categorically argues for radical thinking in the sector which is vital in rationalising neopatrimonial attitudes (see Habermas, 1987). One staff union leader said the following:

I would speak for... if we are really to move forward .... college needs a bit of independence from the government. They can do a few things without necessarily consulting government or government should stop changing conditions of service on their own without consulting us, it should stop dictating on what fees which we should be charging our students and this is one area that is taking us backward because the fees that the students are paying is too low. But we have no powers to raise the fees...they tell us that we have to source money from income generating activities such as rearing chickens but I think people have said that is not our business. We cannot be here to sell chickens our core business is to teach and our only source of money could be fees and consultancy but you know there is very little consultancy in Malawi. After all $80 \%$ goes to the owner of the consultancy and 20\% goes to the system so people came to a conclusion that as long as the fees are where they are this place cannot expand, and people will continue leaving this place because you cannot raise their salaries. So long as the frustration is at the level it is, I can only see people going away. The only way to make progress is to charge reasonable fees.

The major argument presented by the respondent touches on autonomy of the university. The respondent argues for a need for the university through its council to determine issues such as fees to be paid by university students. While the fee issue is contested, the respondent makes a point on institutional autonomy. The implicit problem discerned by the respondent is that the government keeps fees too low for the running of the university because it 
wants to be politically correct. More autonomy given to the universities would be useful in lessening or curbing the interventionist ways of university policysteerage by the Malawi Government. One university manager mentioned the following:

I think first of all its coordination, how we can make the university more autonomous from the government interference. I think if we do that we shall make the university comparative to other universities. In other words the vision of the university should not be downgraded because of in-country policies. We are now in a global village if we are going to move as a university we have to be competitive at regional and international level. Our level of academic, science... should be matching up. Right now the university ... is number 68 on... ranking and number one is UCT ${ }^{25}$... We have to have an approach that translates Science and Technology to the country.

The respondent argues for greater autonomy for the university sector to determine its future without government interference. The problem with government interference as shown earlier is that it is interventionist and woven within neopatrimonial attitudes as such it becomes difficult for the university sector to focus on its core business. Unless this situation changes, chances are that democratic governance in Malawian universities shall be farfetched.

\section{4. Conclusion}

Chapter 11 has presented respondents' views on improving the management and governance of the university sector in Malawi. At university level respondents argue for a need for participatory governance that adheres to a listening spirit and one that avoids same officers making decisions both at senate and council. More so, they propose a need for collaborative research between academics and students. At national policy level, they propose a need for the establishment of the National Council for Higher Education;

25 UCT is short form for the University of Cape Town 
changes in national university curricula and related issues; support by Government to private universities; engaging the civil society in policy praxis; a strong national student union and a need for widening access to university education. At state-policy steerage level, they advocate for greater autonomy for the university sector. While respondents' views do not adhere to Critical Theory, they provide basis for the theory on university management and governance based on Critical Theory aimed at emancipation advanced in chapter 12 , which concludes this thesis. 


\section{Chapter 12}

\section{Toward Emancipation: A theory of university management and governance for Malawian universities based on Critical Theory}

\subsection{Introduction}

This chapter concludes the thesis. Having examined anti-democratic practices within university policy-steerage, management and governance in Malawi at international, university and government levels, following a Horkhermian Framework, this chapter identifies actors to change the anti-democratic practices and proposes a theory of university management and governance for Malawian universities based on Critical Theory as a way of achieving emancipation. The chapter revisits the identified anti-democratic practices before identifying actors of change and developing the emancipatory theory.

\subsection{Challenges and problems revisited}

As noted, the thesis has revealed several challenges that can be summarised as follows: First, that using policy debates or discourses and data, university policy-steerage by the World Bank and partner organisations shows instrumental use of reason within the global-neoliberal-orthodoxy and, is, thus, viewed as anti-democratic.

Second, at university level governance, data show that the neopatrimonial attitude of presidentialism or big-man syndrome permeates the management and governance of universities in Malawi rendering the system instrumental and anti-democratic. 
Third, at Malawi Government university policy-steerage level, data reveal interventionist policy-steerage characterised by both neopatrimonial aspects of presidentialism and patron-client. Following the Horkhermian Framework, the next discussion briefly identifies agents to change the problems identified.

\subsection{Agents of change}

The thesis identifies the following actors of change: university lecturers, university managers and administrators, university students, the civil society, government officials especially in the ministries of planning and education, university chancellors, university council members and the international finance community. These actors are identified because of their potential role both directly and indirectly in democratising university policy-steerage, management and governance in Malawi. As argued earlier, Critical Theory proposes a need for humans to realise that they can engage and change distortions that happen within their societies (Carr \& Kemmis, 1986; Habermas, 1984, 1987). It can be argued that actors of change need to be empowered so as to realise that they have a duty as change agents. The contention is that if the identified actors of change are empowered to view themselves as change agents then they would among other ways: actively participate in university education policy debates and practices in Malawi using the force of reason rather than force of coercion (see Habermas, 1984, 1987). To achieve the desired changes for emancipation, the thesis proposes the following theory of university management and governance based on Critical Theory. 


\subsection{A theory of university management and governance}

This thesis develops a theory of university management and governance based on Critical Theory as a way of achieving emancipation in the university sector in Malawi. The theory embodies two ideas: dialectical reasoning and communicative rationality. First, the ideas of dialectical reasoning and communicative rationality are briefly explained.

As noted, the idea of dialectical reasoning entails understanding things as they are now and what they might be in future (Adorno, 1982; Carr, 2000; How, 2003). For example, for Hegel, dialectics meant that the particular and the universal were interdependent (How, 2003), revealing the idea that reality is a becoming. Similarly, summarising Bernstein's argument on dialectical reasoning, Carr (2000) posits as follows:

The dialectical process begins with a thesis, any definable reality that is the starting point from which all further developments precedes...reflection progresses and this thesis is seen to encompass its opposite or antithesis as part of its very definition. One moment of the dialectic process gives rise to its own negation...what emerges from the dialectic of affirmation and negation is a transcendent moment that at once negates, affirms, and incorporates all the previous moments (Carr, 2000, pp. 212-213).

Thus, dialectical reasoning demands constant questioning or reflexivity conceived as involving three moments: thesis, antithesis and synthesis (Carr, 2000). In this questioning, reality embodies the reflexive mind that negates the self evident nature of reality (see Adorno, 1982; Carr, 2000; Grubbs, 2000; Horkheimer, 1978; Marcuse, 1978). Adorno describes the idea of dialectal reasoning as follows:

Dialectics is the quest to see the new in the old instead of just the old in the new. As it mediates the new, so it preserves the old as the mediated. If it were to proceed according to the schema of sheer flow and indiscriminate vitality, then it would degrade itself to a replica of the amorphous structure of nature, which it should not sanction through mimicry, but surpass through cognition. Dialectics gives its 
own to the old as reified and consolidated, which dialectic can move only by realising the force of its own weight (Adorno, 1982, pp. 38-39).

Dialectical reasoning also entails seeing the new in the old other than just the old in the new (Adorno, 1982). Like Hegel, Adorno holds that the dialectic always involves asking questions about, what a future might be, from what is now. As such, other than viewing matters in nomothetic terms, dialectical reasoning demands continuous questioning of reality (Carr, 2000). It can be argued that in terms of dialectical reasoning, "the real field of knowledge is not the given facts about things as they are, but the critical evaluation of them as a prelude to passing beyond their given form" (Marcuse, 1941, p. 145). How (2003) argues that for Marcuse and the first generation Critical Theorists, thus, reality does not rest on positivist approaches but on constant reflection on how things may become better in the future. For example, "for human justice to exist, to be justice at all, it must suggest the potentiality of fairness, rightness, equity and so forth" (How, 2003, pp. 3-4). Marcuse argues as follows:

Dialectical thought invalidates the a priori opposition of value and fact by understanding all facts as stages of a single process - a process in which subject and object are so joined that the truth can be determined only within the subject-object totality. All facts embody the knower as well as the doer; they continuously translate the past into the present. The objects thus contain subjectivity in their very structure (Marcuse, 1978, p. 445).

Following on Marcuse, positivist theorising, for example, negates the very nature of questioning by celebrating the givenness of reality (see Adorno, 1982; Grubbs, 2000; Horkheimer, 1978; Marcuse, 1978). For Marcuse and fellow first generation Critical Theorists, understanding reality is a process of interaction between the knowing subject and the researched in a dialectic manner. In other words, reality entails assuming, a becoming, facilitated by dialectical reasoning in which the knowing subject employs reflexivity and adds new knowledge about reality. As noted, in this thesis the idea of dialectical reasoning is complemented by the Habermasian theory of communicative action or rationality in providing an emancipatory theory to 
curb the identified anti-democratic practices within the university sector in Malawi.

The Habermasian theory of communicative rationality is against instrumental reasoning. As noted, the phrase instrumental reasoning was coined by Horkheimer following on Weber's argument that in western society, reason was being used for social control by some people (see Marcuse, 1968; Rasmussen, 2004). This meant for Weber, that reason became devoid of its emancipatory role as it was being used for manipulative purposes (Rasmussen, 2004). It is this manipulative nature employed through reason that Horkheimer termed instrumental reason or force of reason for social control (Rasmussen, 2004). In explaining the stance taken by Horkheimer, Grubbs (2000) argues as follows:

In contemporary society our very notions of mind and reason - or our intellectual capability and human understanding - are meaningless, as we have lost the connection between means and ends. Without the link, knowledge has become nothing more than an instrument, supporting the self-perpetuation of the powerful and ensuring a broad deterioration in the human condition (Grubbs, 2000, pp. 222-223).

As such, "instrumental reason would represent the ever expanding ability of those who were in positions of power in the modern world to dominate and control society for their own calculating purposes" (Rasmussen, 2004, p. 14). It is against the domination and colonising effects of the powerful through instrumental reasoning, that the thesis suggests that communicative rationality as argued by Habermas would be helpful to bring about emancipation within the university sector in Malawi.

As argued in chapter 3, Habermas posits critique within communicative action in which actors seek to reach common understanding and coordinate actions by reasoned arguments, consensus and cooperation, rather than instrumental reasoning or strategic action aimed at manipulation (Habermas, 1984). Habermas describes four kinds of social action in society: teleological, 
normatively regulated, dramaturgical action and communicative action (Habermas, 1984). “In teleological action the actor attains an end or brings about the occurrence of a desired state by choosing means that have promise of being successful in the given situation and applying them in a suitable manner" (Habermas, 1984, p. 85). Habermas contends that strategic action is a subset of teleological action in which actors choose and calculate means and ends for reasons of utility. Habermas criticises teleological action because actors are only interested in the realisation of their own ends (Habermas, 1984).

In normatively regulated action, members of a social group orient their action to common values as such "the individual actor complies with or violates a norm when in a given situation the conditions are present to which the norm has application" (Habermas, 1984, p. 85). Habermas criticises the normatively regulated action because actors are simply interested in consensual action of an already existing agreement (Habermas, 1984).

In a dramaturgical action "the actor evokes in his public a certain image, an impression of himself, by more or less purposefully disclosing his subjectivity" (Habermas, 1984, p. 86). Habermas criticises the dramaturgical action because the actor presents oneself in relation to an audience.

Habermas supports communicative action. He makes the claim that unlike the other social actions, the original mode of language is communication and that consequently, discourse, embodies emancipation (Habermas, 1984, 1987). He argues as follows:

...the use of language with an orientation to reaching understanding is the original mode of language use, upon which indirect understanding, giving something to understand or letting something to be understood, and the instrumental use of language in general are parasitic (Habermas, 1984, p. 288). 
The use of language for communication is a condition for understanding and agreement based on the use of reason as opposed to use of force or manipulation such as in instrumental rationality (Morris, 2006, 2009).

As noted in chapter 3 , Habermas advances the idea that communicative action is complemented by a theory of the lifeworld (Habermas, 1984,1987) in which he contends that subjects acting communicatively always come to an understanding in the horizon of a lifeworld or a cultural, social and shared meaning context (see Habermas, 1984, 1987; Leet, 1998; Morris, 2006). As such, the "lifeworld provides context in which actors come to know themselves, where they ask questions of each other raising validity claims about what is true or force, right or wrong, about what should or should not happen" (How, 2003, p. 128). It is argued that the idea of a lifeworld gives contextual background to communicative action. "With every utterance, the speakers and hearers bring forth a cultural, social and normative space of shared meaning contexts that serve the largely unquestioned background against which the act of speech occurs" (Morris, 2006, p. 238).

As noted in chapter 3 , the lifeworld is also posited as the taken-for-granted. The danger is that this shared context in which meaning is derived could be informed by distortions and anti-democratic practices, thus, the need to rationalise the lifeworld (Carr \& Kemmis, 1986; Habermas, 1987; Morris, 2009). For Habermas, "a critique...can indeed be based on the procedural concept of communicative rationality if it can be shown that the decentration of world understanding and the rationalisation of the lifeworld are necessary conditions for an emancipated society" (Habermas, 1984, p. 74). In other words there is a need to question the taken-for-granted. Habermas posits as follows:

The more cultural traditions predecide which validity claims, when, where, for what, from whom, and to whom must be accepted, the less the participants themselves have the possibility of making explicit and examining the potential grounds on which their yes/no positions are based (Habermas, 1984, p. 70). 
Rationalisation demands that validity claims that may be influenced by the lifeworld need to be exposed to criticism and deliberation based on reason (Habermas, 1984). This means that argumentation facilitated through communicative rationality is, as such, key in rationalising the lifeworld (Habermas, 1998).

Communicative action enforces Habermas' idea of deliberative or discursive democracy (see Habermas, 1998) in which a speaker ought to convince only by using good reasons. Argumentation for Habermas entails achieving consensus using reason (Habermas, 1998). Deliberative democracy serves four major purposes: legitimising ideas made through consensus, encouraging interest in public issues that require rectifying, encouraging respect for one another in decision-making processes and correcting mistakes that may stem from people's misunderstanding of issues (Gutman \& Thompson, 2004).

All in all, it is argued that opposed to instrumental reasoning, communicative rationality seeks to achieve democratic ways of policy-steerage. The tenets of communicative action can be summarised as follows:

1. Rationality: that in decision or policy-making respondents engage each other with reasoned arguments

2. Inclusivity: that decision or policy-making is collective

3. Domination free: that participants in policy-making should make decisions freely without interference by institutional powers (e.g. government authority, university authority, economic authority etc)

4. Equal treatment of respondents: that participants in society are respected only on the basis of the use of reason and not positions of power

5. Consensus: that discussions or policy-making processes that use the force of reason aim at consensus other than empty deliberation and, 
that decisions are open to constant critique and thus open to change with realisation of new realities (Habermas, 1984, 1987).

The thesis, thus, presents the two ideas as central to a proposed theory of university management and governance in Malawi. Dialectical reasoning is pertinent to the theory in that it presents social reality as in a constant transformation through human ongoing reflexivity. Communicative rationality is significant in its use of reason, inclusivity, domination free, equality and consensus in policy-making. Communicative rationality entails that university policy-steerage, management and governance in Malawi ought to be a democratic affair in which domination is avoided in favour of rationality (Habermas, 1984, 1987, 1991, 1998). Communicative rationality also contributes to emancipation through the rationalisation of the lifeworld, the taken-for-granted. In this thesis, neopatrimonial modes of thought are viewed as providing a lifeworld that requires rationalising through argumentation to achieve emancipation. These two ideas are helpful in rationalising the neopatrimonial attitudes that permeate the running of the universities in Malawi and in curbing instrumental reasoning in policy praxis generally.

\subsubsection{Emancipation at international level}

As noted, the major problem at international level is that the World Bank leadership employs instrumental use of reason in its policy-steerage in Malawi within the global-neoliberal-orthodoxy. Given this problem at international level, the thesis proposes that the World Bank and its partner organisations and the Malawi Government ought to realise that they are change agents for creating a more just environment in university policy-steerage. The idea is that the leadership of the World Bank needs to reduce its dominating tendency in policy-steerage. 
The Malawi Government would play agency against the global-neoliberalorthodoxy by advocating that the World Bank revisits its generalised policysteerage mechanisms noted in the thesis. The thesis, however, acknowledges that the level of agency depends on the way the World Bank's leadership is prepared to embrace social justice, as it is the one endowed with power and is economically privileged over the Malawi Government.

One way for the World Bank to reduce its dominating tendency is by embracing dialectic reasoning. By embracing dialectical reasoning, the World Bank's leadership shall be able to interrogate its policy-steerage to avoid being manipulative. It is expected that this would facilitate the World Bank to revisit its hegemonic power that has been legitimised for example, through the PostWashington Consensus in Africa generally.

Dialectic reasoning by the World Bank's leadership ought to be complemented by communicative rationality in which the use of power or force is replaced by the use of reason in coming up with university policies in Malawi (see Habermas, 1984, 1987). Embracing communicative rationality would mean that the World Bank and partner organisations take university decisions not based on the fact that it is powerful and economically privileged over the Malawian Government, but based on the use of reason and consensus through the process of argumentation. The use of reason would give a chance to the Malawi Government to chart its own relevant policies even if the World Bank is providing funds for them. The Malawi Government leadership as argued earlier could facilitate communicative rationality by involving professionals and experts such as those from the university sector in engaging with the World Bank and partner organisations on university policy. There is a need for the Malawi Government leadership to prioritise policies within the university sector that are relevant to the situation in Malawi. There is a need for scrutinising policy-steerage by the World Bank for the availability of funding only, does not suffice to adopt new policies (see Banya \& Elu, 2001). The recent out-sourcing policy in Malawian universities is a case in point. 
In general terms, adhering to dialectical reasoning and communicative rationality has the potential to reduce anti-democratic practices within the international policy-steerage in Malawi and lead to emancipation.

\subsubsection{Emancipation at university level}

As noted, at university level the thesis reveals that the neopatrimonial attitude of presidentialism or big-man syndrome permeates the management and governance of universities in Malawi rendering the system instrumental and anti-democratic. Thus, at this level; academics, university managers and students need to view themselves as change agents to change the big-man syndrome. Two ways are proposed to achieve this change: first is by offering deliberate training to university managers or administrators, academics and student leaders to view leading as a constant process of reflection to achieve best practices in dialectic way. Second, is by challenging the big-man syndrome which represents a lifeworld or a taken-for-granted through argumentation based on communicative rationality (see Habermas, 1984).

Training university and student leaders to view leading in dialectical terms within universities in Malawi has the potential to encourage leaders to constantly think about improving their managerial and administrative skills to achieve social justice within the university. Such leaders will be able to view their leading skills within realms of thesis, antithesis and synthesis and be open to critique and improvement. This means viewing leading as always in a process of becoming, precisely, becoming better. Dialectical reasoning shall, thus, assist university leaders in Malawi not to be preoccupied with power and control (as revealed in the thesis) that make them maintain the big-man syndrome, but to recognise and work for social justice (see Carr, 2000). As noted, viewing leading as a becoming better, shall help university leaders to see the new in the old and not just the old in the new (Adorno, 1982), so as to think about changing and improving their practices generally. 
University leaders in Malawi, employing dialectic reasoning, will realise that within the demands of dialectical reasoning, they, themselves are subjects of change (see Carr, 2000). As such, instead of viewing others as needing change, they will begin to question their own taken-for-granted standpoints that require changing for the better. This is expected to curb the manipulative and instrumental way of reasoning that aims at controlling the less powerful stakeholders within the Malawian universities, as reflected in relationships between managers and academics and between academics and students.

Dialectal reasoning has the potential to contribute to achieving some level of autonomy by stakeholders within the university. For example, lecturers who think dialectically shall be able to give some level of autonomy to learners to manage their own learning in a reflexive manner. Lecturers employing dialectical reasoning shall, thus, be more open to critique and facilitate a reflexive learning for their students and avoid using their power such as of grading students' work to stifle students' creativity.

To complement dialectic efforts, there is a need to use communicative rationality to rationalise the neopatrimonial attitude of the big-man syndrome that permeates the management and governance of universities in Malawi. Rationalising the neopatrimonial attitude of the big-man syndrome at university level, will require putting up structures that allow for argumentation, debates and critique of campus life such as managerial practices, the learning environment, academic freedoms and university autonomy, research and all that embraces university life. Such deliberations ought to include discussing sensitive issues such as regionalist politics in Malawi in view of using reason to change attitudes.

All in all there is a need to advance a deliberative democratic culture within the university sector. Dialectical reasoning and communicative rationality ought to be reflected in the whole national education system or curricula for 
sustained change in reducing anti-democratic practices highlighted at this level.

\subsubsection{Emancipation at Malawi Government level}

As noted, at Malawi Government university policy-steerage level, the thesis reveals interventionist policy-steerage characterised by both neopatrimonial aspects of the big-man syndrome and patron-client mechanisms. At this level, it is helpful for the university chancellors (state presidents), university council members, university managers, university lecturers, students and the civil society in general to view themselves as agents to change the interventionist policy-steerage and neopatrimonial aspects of the big-man syndrome and patron-client. This will require working on the powers used by university chancellors (presidents) and providing for dialectic reasoning and communicative rationality to rationalise the neopatrimonial attitudes identified.

One way of avoiding interventionist policy-steerage is by revisiting the role of state presidents as university chancellors and avoiding perpetuating the bigman syndrome displayed by them. The idea is that policy-steerage ought not to be a one man show rather one that reflects a consensus by the reasoning community (Habermas, 1984). This means that the university council members and the university management generally, ought to employ the power of reason in order to avoid succumbing to narrow political interventions within the university system perpetuated by the chancellors. University chancellors or state presidents will need to realise a need for sustaining a university system that does not depend on their benevolence which only perpetuates the big-man syndrome. University councils in public universities in Malawi ought to consider employing academic professionals as university chancellors other than state presidents to avoid problems already highlighted in this thesis. 
There is a need for deliberate training of politicians and government officials concerned with the university sector to embrace dialectical leading. Embracing dialectic reasoning at political level (concerned with university policy in Malawi) shall be helpful in producing politicians that take their actions as a constant reflection to improve the sector other than to control and manipulate university stakeholders.

To rationalise neopatrimonial attitudes of big-man syndrome and patronclient, there is a need for establishing a strong national communicative community in which the identified agents could employ the force of reason to deliberate the anti-democratic nature of the attitudes. There is a need for a strong civil society such as national students and staff unions to initiate deliberation on major issues that affect the university sector, such as regionalist politics and the big-man syndrome. It is argued that in so doing, these groups would represent a strong public sphere that could, through argumentation, rationalise aspects of neopatrimonialism at this level.

Embracing communicative rationality would allow politicians and government officials to engage in a deliberative way in policy-formulation and create an enabling democratic environment in Malawi. For example, the quota selection policy would have benefited from such engagement if those steering it did not harbour instrumental use of reason. Both dialectical reasoning and communicative rationality would help politicians, as well as government officials, to rethink their un-critical stances, that foster anti-democratic practices such as regionalist politics in Malawi, in order to achieve a just environment.

In general, the theory of university management and governance advanced in this thesis is aimed at enhancing university stakeholders in Malawi to use and create conditions for self reflexive critique in order to challenge domination and achieve democratic policy-steerage and practices in Malawian universities 
(Habermas, 1984, 1987, 1998). There is a need to create an open society that is discursive in nature at international, government and university levels in order to foster democratic practices within the university sector in Malawi generally. This theory is therefore an ideological critique of instrumental reasoning and neopatrimonial modes of thoughts in policy-steerage, management and governance of the university sector in Malawi.

\subsubsection{Summary of the emancipatory promise}

Given the suggestions presented by respondents in chapter 11 and concerns for emancipation in this chapter, the following is a summary of required interventions to democratise university policy-steerage, management and governance in Malawi:

1. Advancing dialectical reasoning at every level of university leadership to avoid instrumental use of reason.

2. Facilitating communicative rationality in international university policy-steerage by involving university policy experts as well as experts from the public in discussing donor driven initiatives affecting the international university policy-steerage in Malawi.

3. Enhancing the public sphere by strengthening the civil society that could assist in giving direction to university education policy-making in Malawi.

4. Rationalising (in a Habermasian sense) the neopatrimonial aspect of big-man syndrome at university level through argumentation using communicative rationality.

5. Introducing or enhancing participatory governance at university level to counter the big-man syndrome that permeates university governance, resulting into constrained faculty led decision-making, rivalry relationship among stakeholders and constrained students 
participation in decision-making processes. This will require a high level of transparency and trust among stakeholders.

6. Rationalising neopatrimonial aspects of big-man syndrome and patronclient at Malawi Government university policy-steerage level through argumentation using communicative rationality.

7. Providing national curricula that reflect dialectical reasoning and communicative rationality and encourage a general deliberative culture within the whole national education system in Malawi.

8. Bringing mechanisms to support the growth of private universities, which shall in turn widen university education access that is most crucial in the university education sector in Malawi. In this way, the country could avoid patron-client regionalist and interventionist policies such as the contested quota selection of university policy.

9. Enacting Access to Information Act to enable people to access information when required so as to have informed policy debates that can allow for democratic policy-making

10. Adhering to maintaining academic freedom and institutional autonomy in Malawian universities.

11. Providing a relevant curriculum in the university, that does not only apply to the global-neoliberal-orthodoxy and the knowledge economy rhetoric, but one in which the public role of the university is upheld.

12. Providing for independent or quasi-independent defensible university education policy frameworks, such as the National Council for Higher Education, to avoid the neopatrimonial logic permeating defensible higher education policy frameworks.

The thesis has identified issues for further research helpful to further understand anti-democratic practices within the university sector in Malawi and Africa generally. 


\subsection{Issues for further research}

Having identified problems within the university policy-steerage, management and governance in Malawi; suggested agents of change and provided an emancipatory theory, the thesis suggests further issues for research. This is important because the thesis has revealed gaps in knowledge that require addressing. The following are some of the identified issues for further research:

1. Global forces and policy-making in Africa;

2. Neopatrimonialism and social services (e.g. Education and Health) in Africa;

3. The impact of power and bureaucracy on the running of African universities;

4. Analyses of the interaction between the global and the local in development policies in Africa (making a connection to education); and

5. Understanding universities as organisations in Africa (e.g. using insights of the new-institutionalism theory).

6. Equity and differentiated participation in higher education in Malawi.

\subsection{Final word}

This thesis proposes critique of instrumental use of reason and neopatrimonial modes of thoughts that affect policy-steerage, management and governance of the university sector in Malawi. The proposals are based on Critical Theory, which has enabled the research to conceive an emancipatory project. The thesis presents the idea that to achieve emancipation, it is necessary to contain aspects that perpetuate manipulative behaviour, such as the big-man syndrome through dialectical reasoning and communicative rationality. 
The thesis contributes to the development of Critical Theory and its practical application. It helps in understanding how Critical Theory as an emancipatory theoretical framework can help to assess the nature of anti-democratic practices within an education system such as in Malawi. For example, using Habermas' theory of the lifeworld helps in understanding how the taken-forgranted neopatrimonial aspects permeate the management of the university sector in Malawi and in suggesting change through argumentation. Through both dialectical reasoning and communicative rationality the thesis helps in understanding how the use of power such as by the World Bank and university actors degenerates to social control and manipulative behaviours. The thesis advances a need for a deliberative culture in policy-steerage, management and governance of the university sector. 


\section{REFERENCES}

Adedeji, A. (1999). Structural adjustment policies in Africa. International Social Science Journal, 51(162), 521-528.

Adorno, T. (1982). Against epistemology: A metacritique. Oxford: Basil Blackwell Publisher Ltd.

Ajayi, J. F., Goma, L. K. H., \& Johnson, G. A. (1996). The African experience with higher education. Accra: Ohio University.

Allen, J. (1995). Global Worlds. In J. Allen \& D. Massey (Eds.), Geographical Worlds. Oxford: The Open University.

Altbach, P. (2005). Academic freedom: International challenges and African realities. JHEA/RESA, 3(1), 17-34.

Assié-Lumumba, N. (2005). Critical perspectives on the crises, planned change and the prospects for transformation in African Higher Education. JHEA/RESA, 3(3), 1-29.

Assié-Lumumba, N. (2006). Higher education in Africa: Crisis, reforms and transformation. Dakar, Senegal: CODESRIA.

Association of African Universities. (2004). Higher education in Sub-Saharan Africa: With specific reference to universities. Accra: Association of African Universities.

Bailey, C. (2007). A guide to qualitative field research. Thousand Oaks: Pine Forge Press.

Banya, K. (2001). Are private universities the solution to the higher education crisis in sub-Saharan Africa? Higher Education Policy, 14(16), 161-174.

Banya, K., \& Elu, J. (2001). The World Bank and financing higher education in Sub-Saharan Africa. Higher Education, 42(1), 1-34.

Beckmann, A., \& Cooper, C. (2004). Globalisation, the new managerialism and education: Rethinking the purpose of education in Britain. Journal for Critical Education Policy Studies, 2(2). 
Beckmann, A., Cooper, C., \& Hill, D. (2009). Neoliberalisation and managerialisation of education in England and Wales: A case for reconstructing education. Journal for Critical Education Policy Studies, $7(2), 311-345$.

Berkhout, S., \& Wielemans, W. (1999). Towards understanding educational policy: An integrative approach. Educational Policy, 13(3), 402-420.

Birkland, T. A. (2005). An Introduction to the policy process: Theories, concepts and models of public policy making. New York: M.E. Sharpe.

Bleiklie, I., \& Kogan, M. (2007). Organisation and governance of universities. Higher Education Policy, 20, 477-493.

Bloom, D., Canning, D., \& Chan, K. (2006). Higher education and economic development in Africa. Harvard: Harvard University.

Bloom, D., \& Rosovsky, H. (2007). Higher education in developing countries. In J. Forest \& P. Altbach (Eds.), International handbook of higher education (Vol. 18, pp. 443-459). Dordrecht: Springer.

Bohman, J. (1996). Critical theory and democracy. In D. Rasmussen (Ed.), The handbook of critical theory (pp. 190-215). Cambridge: Blackwell Publishers Ltd.

Bolton, R. (2005). Habermas's theory of communicative action and the theory of social capital. Paper presented at the Meeting of Association of American Geographers, Denver, Colorado.

Booth, D., Cammack, D., Harrigan, J., Kanyongolo, E., Mataure, M., \& Ngwira, N. (2006). Drivers of change and development in Malawi. London: Overseas Development Institute.

Boyce, C., \& Neale, P. (2006). Conducting in-depth interviews: A guide for designing and conducting in-depth interviews for evaluation input. Watertown: Pathfinder International.

Bratton, M., Gyimah-Boadi, E., \& Mattes, R. (Eds.). (2004). Sources of ethnic identification in Africa. Cape Town: Afrobarometer. 
Bratton, M., \& van de Walle, N. (1997). Democratic experiments in Africa: Regime transitions in comparative perspective. Cambridge: Cambridge University Press.

Briefs, G. (1939). The rise and fall of proletarian utopias. The Review of Politics, 1(1), 31-50.

Brock-Utne, B. (1996). Globalisation of learning- the role of the universities in the south: With a special look at sub-Saharan Africa. Educational Development, 16(4), 335-346.

Brock-Utne, B. (2003). Formulating higher education policies in Africa: The pressure from external forces and the neo-liberal agenda. JHEA/RESA, 1(1), 24-56.

Bryman, A. (2008). Social research methods. Oxford: Oxford University.

Cammack, D. (2007a). 'Big Men', governance and development in neopatrimonial states. Retrieved 23, 2009, from http://www.odi.org.uk/resources/download/4746.pdf

Cammack, D. (2007b). The logic of African Neopatrimonialism: What role for donors? Development Policy Review, 25(5), 599-614.

Cammack, D., Golooba-Mutebi, F., Kanyongolo, F., \& O'Neill, T. (2007).

Neopatrimonial politics, decentralisation and local government: Uganda and Malawi 2006. Retrieved 18, 2009, from http://www.ids.ac.uk/files/dmfile/CammacketalGAPWP2.pdf

Canales, M. K. (2000). Othering: Toward an understanding of difference. Advances in Nursing Science, 22(4), 16-31.

Carr, A. (2000). Critical theory and the management of change in organisations. Journal of Organisational Change, 13(3), 208-220.

Carr, A., \& Kemmis, S. (1986). Becoming critical: Education, knowledge and action research. London: The Farmer Press.

Chirambo, R. M. (2001). Protesting politics of "death and darkness" in Malawi. Journal of Folklore Research, 38(3), 205-227. 
Chirambo, R. M. (2004). "Operation bwezani": The army, political change, and Dr. Banda's hegemony in Malawi. Nordic Journal of African Studies, 13(2), 146-163.

Chirambo, R. M. (2007). Subverting Banda's dictatorship in Malawi: Orality as counter-discourse in Jack Mapanje's of chameleons and gods. ArielCalgary, 38(2-3), 139-158.

Chirambo, R. M. (2009). Democracy as a limiting factor for politicised cultural populism in Malawi. Africa Spectrum, 44(2), 77-94.

Chirwa, W. (1994). Elections in Malawi: the peril of regionalism Retrieved 12, 2009, from http://www.africafiles.org/printableversion.asp?id=3967

Cho, J., \& Trent, A. (2006). Validity in qualitative research revisited. Qualitative Research, 6(3), 319-340.

Chou, C. (2008). The impact of neo-liberalism on Taiwanese Higher Education. International Perspectives on Education and Society, 9, 297-311.

Claussen, J., Amis, P., Delay, S., \& McGrawth, J. (2006). Joint evaluation of general budget support 1994-2004: Burkina Faso, Malawi, Mozambique, Nicaragua, Uganda, Vietnam: Malawi Country Report. Birmingham: International Development Department.

Cohen, L., Manion, L., \& Morrison, K. (2007). Research methods in education London: Routledge.

Creswell, J. (2002). Research design: qualitative, quantitative and mixed method approaches. Newbury: SAGE.

D'Cruz, H., Gillingham, P., \& Melendez, S. (2007). Reflexivity, its meanings and relevance for Social Work: A critical review of the literature. British Journal of Social Work, 37, 71-90.

Davies, B., Gottsche, M., \& Bansel, P. (2006). The rise and fall of the neo-liberal university. European Journal of Education, 41(2), 305-319.

Delanty, G. (2003). Ideologies of knowledge society and the cultural contradictions of higher education. Policy Futures in Education, 1(1), 7182. 
Denzin, N. K., \& Lincoln, Y. S. (2003). The disciplines and practice of qualitative research. In N. K. Denzin \& Y. S. Lincoln (Eds.), Strategies of qualitative inquiry (pp. 1-45). Thousand Oaks: SAGE.

Dye, R. T. (1987). Under-standing public policy. Englewood Cliffs: Prentice Hall.

Engel, U., \& Erdmann, G. (2007). Neopatrimonialism reconsidered: Critical review and elaboration of an elusive concept. Commonwealth \& Comparative Politics, 45(1), 95-119.

Enslin, Pendlebury, \& Tjiattas. (2001). Deliberative democracy, diversity and the challenges of citizenship education. Journal of Philosophy of Education, 35(1), 116-130.

Erdmann, G., \& Engel, U. (2006). Neopatrimonialism revisited-beyond a catchall concept. Retrieved 14, 2010, from http://ideas.repec.org/p/gig/wpaper/16.html

Fielden, J. (2008). Global trends in university governance: Working paper series number 9. Washington DC: World Bank.

Flick, U. (2006). An Introduction to qualitative research. London: SAGE

Forester, J. (1993). Critical theory, public policy and planning practice: Towards a critical pragmatism. New York: State University of New York.

Forst, R. (1996). Justice, reason, and critique: basic concepts of critical theory. In D. Rasmussen (Ed.), The handbook of critical theory (pp. 138-162). Cambridge: Blackwell Publishers.

Fraser, A. (2005). Poverty Reduction Strategy Papers: Now who call the shots? Review of African Political Economy, 104(5), 317-340.

Fritzell, C. (2002). Pedagogic practice and deliberative democracy. Paper presented at the European Conference on Educational Research, Lisbon, Portugal.

Gaidzanwa, R. (1994). Governance issues in African universities: Improving management and governance to make African universities viable in the 1990s and beyond. Accra: Working Group on Higher Education. 
Gentile, E. (1990). Fascism as a political religion. Journal of Contemporay History, 25(2/3), 229-251.

Geo-Jaja, M., \& Zadja, J. (2005). Rethinking globalisation and the future of education in Africa. In J. Zadja (Ed.), International handbook on globalisation, education and policy research (pp. 109-129). Dordrecht: Springer.

Gewirtz, S., \& Ball, S. (2000). From welfarism to new managerialism: Shifting discourses of school headship in the education market place. Discourse: Studies in the Politics of Education, 21(3), 253-268.

Gilman, L. (2001). Purchasing praise: Women, dancing and patronage in Malawi party politics. Africa Today, 48(4), 43-64.

Gilman, L. (2004). The traditionalisation of women's dancing, hegemony, and politics in Malawi. Journal of Folklore Research, 41(1), 33-59.

Giroux, H. (2003). Selling out higher education. Policy Futures in Education, 1(1), 179-200.

Golafshani, N. (2003). Understanding reliability and validity in qualitative research. The Qualitative Report, 8(4), 597-607.

Gornitzka, A. (1999). Governmental policies and organisational change in higher education. Higher Education, 38(1), 5-31.

Grubbs, J. (2000). Cultural imperialism: A critical theory of interorganisational change. Journal of Organisational Change, 13(3), 221-234.

Gutman, A., \& Thompson, D. (2004). Why deliberative democracy. Princeton: Princeton University Press.

Habermas, J. (1984). The theory of communicative action: Reason and the rationalisation of society. Boston: Beacon.

Habermas, J. (1987). The theory of communicative action: Lifeworld and system: A critique of functionalist reason. Boston: Beacon.

Habermas, J. (1991). The structural transformation of the public sphere. Cambridge: The MIT Press. 
Habermas, J. (1998). Between facts and norms. Cambridge: the MIT Press.

Habib, A., Morrow, S., \& Bentley, K. (2008). Academic freedom, institutional autonomy and the corporatised university in contemporary South Africa. Social Dynamics, 34(2), 140-155.

Hall, K. (2005). Science, globalisation and educational governance: the political rationalities of the new managerialism. Indiana Journal of Global Legal Studies, 12(1), 153-182.

Hansen, S., Berente, N., \& Lyytinen, K. (2009). Wikipedia, critical social theory and the possibility of rational discourse. The Information Society, 25(1), 38-59.

Hartz-Karp, J. (2007). How and why deliberative democracy enables cointelligence and brings wisdom to governance. Journal of Public Deliberation, 3(1), Article 6.

Harvey, L., \& Green, D. (1993). Defining quality. Assessment and Evaluation in Education, 18(1), 9-34.

Hayward, M. F., \& Ncayiyana, D. J. (2006). Report on the National Education Sector Plan Project: 30th October-18 November 2006. Lilongwe: Ministry of Education and Vocational Training (MoEVT).

Horkheimer, M. (1978). The end of reason. In A. Arato \& E. Gebhardt (Eds.), The essential Frankfurt School reader (pp. 26-48). New York: Urizen Books.

How, A. (2003). Critical Theory. New York: Palgrave Macmillan.

Howlett, M., \& Ramesh, M. (1995). Studying public policy: Policy cycles and policy subsystems. Oxford: Oxford University.

Ibhawoh, B. (1999). Structural adjustment, authoritarianism and human rights in Africa. Comparative Education of South Asia, Africa and the Middle East, XIX(1), 158-167.

IMF World Economic Outlook Database. (2008.) Retrieved 26/01/09, 2009, from http:www.globalpropertguide.com/Africa/malawi/gdp-per-capita 
Inhonvbere, J. (1997). From despotism to democracy: The rise of multiparty politics in Malawi. Third World Quarterly, 18(2), 225-247.

Ishengoma, M. J. (2004). Cost-sharing in higher education in Tanzania: Fact or fiction. JHEA/RESA, 2(2), 101-133.

Johnstone, B. B. (2004). Higher education finance and accessibility: Tuition fees and student loans in sub-Saharan Africa. JHEA/RESA, 2(2), 11-36.

Jones, P. (1998). Globalisation and internationalism: Democratic prospects for world education. Comparative Education, 34(2), 143-155.

Kamwendo, G. (1994). Culture, nationalism and the invention of tradition in Malawi. The Journal of Modern African Studies, 32(3), 477-497.

Kamwendo, G. (2004). Your Chitumbuka is shallow. It is not the real Chitumbuka: Linguistic purism among Chitumbuka speakers in Malawi. Nordic Journal of African Studies, 13(3), 275-288.

Kaspin, D. (1995). The politics of ethnicity in Malawi's democratic transition. The Journal of Modern African Studies, 33(4), 595-620.

Kayambazinthu, E. (1998). The language planning situation in Malawi. Journal of Multilingual and Multicultural Development, $19(5$ \& 6), 369-439.

Kayuni, H., \& Tambulasi, R. (2010). The Malawi 1964 cabinet crisis and its legacies of 'perpetual regression of trust' amongst contemporary Malawian politicians. Social Dynamics, 36(2), 410-427.

Kemmis, S. (2006). Exploring the relevance of critical theory for action research: Emancipatory action research in the footsteps of Jürgen Habermas. In P. Reason \& H. Bradbury (Eds.), Handbook of action research (pp. 94-105). London: SAGE.

Kerr, D., \& Mapanje, J. (2002). Academic freedom and the University of Malawi. African Studies Review, 45(2), 73-91.

Kincheloe, J., \& McLaren, P. (2008). Rethinking critical theory and qualitative research. In N. K. Denzin \& Y. S. Lincoln (Eds.), The landscape of qualitative research (pp. 403-456). Thousand Oaks: SAGE. 
King, N., \& Horrocks, C. (2010). Interviews in Qualitative Research. Los Angeles: SAGE.

Kirk, J., \& Miller, M. (1986). Reliability and validity in qualitative research. Beverly Hills: SAGE.

Kolsaker, A. (2008). Academic professionalism in the managerialist era: A study of English Universities. Studies in Higher Education 33(5), 513525.

Krejsler, J. (2006). Discursive battles about the meaning of university: The case of Danish university reform and its academics. European Educational Research Journal, $5(3$ \& 4), 210-220.

Kurer, O. (2007). Why do Papua New Guinean voters opt for clientelism? Democracy and governance in a fragile state. Pacific Economic Bulletin, 22(1), 39-53.

LeCompte, M., \& Goetz, J. (1982). Problems of reliability and validity in ethnographic research. Review of Educational Research, 52(1), 31-60.

Leet, M. (1998). Jürgen Habermas and deliberative democracy. In A. Carter \& G. Stokes (Eds.), Liberal Democracy and its Critics. Cambridge: Polity Press.

Levy, D. (1999). When private higher education does not bring organisational diversity. In P. Altbach (Ed.), Private Prometheus: Private higher education and development in the 21st century (pp. 15-44). London: Greenwood Press.

Levy, D. (2007). A recent echo: African private higher education in an international perspective. JHEA/RESA, 5(2 \& 3), 197-220.

Loken, D., Asher, S., \& Lesire, R. (1977). Malawi Education Sector Survey: Report on the findings of a mission in June/July 1977 to Malawi. Washington DC: World Bank.

Macridis, R. (1952). Stalinism and the meaning of Titoism. World Politics, 4(2), 219-238. 
Malawi Government. (2000a). Policy and Investment Framework (PIF) 20002015. Lilongwe: Malawi Government.

Malawi Government. (2000b). Vision 2020: The national long-term development perspective for Malawi. Zomba: Malawi Central Africana Limited.

Malawi Government. (2006a). Malawi Growth and Development Strategy. Lilongwe: Malawi Government.

Malawi Government. (2006b). National Education Sector Plan. Lilongwe: Malawi Government.

Malawi Government. (2008). 2008 population and housing census. Zomba: Ministry of Economic Planning and Development.

Malawi Government. (2009). Malawi Education Country Status Report (CSR 2008/09). Lilongwe: Malawi Government.

Malawi Law Reports. (2003). Mhango and others v University Council of Malawi. Durban: Butterworths.

Maluwa-Banda, D. (2004). Gender sensitive policy and practice: The case of Malawi. Prospects, XXXIV(1), 71-84.

Marcuse, H. (1941). Reason and revolution: Hegel and the rise of social theory. London: Oxford University Press.

Marcuse, H. (1968). One-dimensional man. Boston: Beacon Press.

Marcuse, H. (1978). A note on dialectic. In A. Arato \& E. Gebhardt (Eds.), The essential Frankfurt School reader (pp. 444-451). New York: Urizen Books.

Marginson, S. (2002). Nation-building universities in a global environment: The case of Australia. Higher Education, 43(3), 409-428.

Marginson, S., \& Considine, M. (2000). The enterprise university: Power, governance and reinvention in Australia. Cambridge: Cambridge University Press.

Matiki, A. (2001). The social significance of English in Malawi. World Englishes, 20(2), 201-218. 
May, T. (1997). Social research: Issues, methods and processes. Buckingham: Open University.

McCabe, J., \& Holmes, D. (2009). Reflexivity, critical qualitative research and emancipation: A Foucauldian perspective. Journal of Advanced Nursing, 65(7), 1518-1526.

Miles, M., \& Huberman, A. M. (1994). Qualitative data analysis. California: SAGE.

Moja, T., Muller, J., \& Cloete, N. (1996). Towards new forms of regulation in higher education: the case of South Africa. Higher Education, 32, 129155.

Morris, M. (2006). Jürgen Habermas (1929-). In J. Simons (Ed.), Contemporary critical theorists: From Lucan to Said (pp. 234-251). Edinburgh: Edinburgh University Press.

Morris, M. (2009). Social Justice and Communication: Mill, Marx and Habermas. Springer, 22, 134-155.

Mtika, P. (2008). Teaching practice as a component of teacher education in Malawi: An activity theory perspective. (Unpublished doctoral dissertation). The University of Nottingham, Nottingham.

Mzuzu University. (1997). Mzuzu University ACT. Mzuzu: Mzuzu University.

Mzuzu University. (2005). Mzuzu University Student Handbook (2005-2006). Mzuzu: Mzuzu University.

Mzuzu University. (2006). Mzuzu University Strategic Plan. Mzuzu: Mzuzu University.

Neuman, L. (2006). Social research methods: Qualitative and quantitative approaches. Boston: Pearson Education Inc.

Ng'ethe, N., Subotzky, G., \& Afeti, G. (2008). Differentiation and articulation in tertiary education systems: A study of twelve African countries. Washington DC: The World Bank. 
Nur-Awaleh, M., \& Mtegha, D. (2005). Shared governance and leadership in African Universities: Experiences from Mzuzu University, Malawi and Amound University, Somaliland. Africa Development, XXX(1), 34-52.

Olsen, M., \& Peters, M. (2005). Neoliberalism, higher education and the knowledge economy: From the free market to knowledge capitalism. Journal of Education Policy, 20(3), 313-345.

Olssen, M., Codd, J., \& O'Neill, A.-M. (2004). Education Policy: Globalisation, citizenship and democracy. London: Sage.

Olssen, M., \& Peters, M. (2005). Neoliberalism, higher education and the knowledge economy: From the free market to knowledge capitalism. Journal of Education Policy, 20(3), 313-345.

Omari, I. M. (1991). Higher education at crossroads in Africa. Nairobi: Man Graphics Limited.

Orb, A., Eisenhauer, L., \& Wynaden, D. (2000). Ethics in qualitative research. Journal of Nursing Scholarship, 33(1), 93-96.

Ordorika, I. (2003). The limits of university autonomy: Power and politics at the Universidad Nacional Autónoma de México. Higher Education, 46, 361-188.

Patton, M. (2002). Qualitative researching and evaluation methods. California: Sage.

Peters, M. (2003a). Classical Political Economy and the Role of Universities in the New Knowledge Economy. Globalisation, Societies \& Education, 1, 153-168.

Peters, M. (2003b). Education policy in the age of knowledge capitalism. Policy Futures in Education, 1(1), 361-380.

Peters, M. (2004). Performative, performativity and the culture of performance: Knowledge management in the new economy (part 1). Management in Education, 18(1), 35-38. 
Peters, M., \& Besley, T. (2004). Building knowledge cultures: Education and development in the age of knowledge capitalism. Lanham: Rowman \& Littlefield Publishers, Inc.

Petocz, A., \& Newbery, G. (2010). On conceptual analysis as the primary qualitative approach to statistics education research in Psychology. Statistics Education Research Journal, 9(2), 123-145.

Posner, D. (1995). Malawi's new dawn. Journal of Democracy, 6(1), 131-145.

Potter, R., Binns, T., Elliot, J., \& Smith, D. (2008). Geographies of development: An introduction to Development Studies. Essex: Pearson Education Limited.

Powell, W., \& Snellman, K. (2004). The knowledge economy. Annual Review of Sociology, 30, 199-220.

Punch, K. F. (1998). Introduction to social research: Quantitative and qualitative approaches. London: SAGE.

Punch, K. F. (2005). Introduction to social research: Quantitative and qualitative approaches London: SAGE.

Ramphele, M. (2004). The university as an actor in development: New perspectives and demands. JHEA/RESA, 2(1), 15-33.

Rasmussen, D. (1996). Critical Theory and Philosophy. In D. Rasmussen (Ed.), The handbook of Critical Theory (pp. 11-38). Cambridge: Blackwell Publishers Ltd.

Rasmussen, D. (2004). Critical Theory and Philosophy. In D. Rasmussen \& J. Swindal (Eds.), Critical Theory (pp. 3-28). London: SAGE.

Rehg, W. (1996). Habermas's discourse theory of law and democracy: An overview of the argument. In D. Rasmussen (Ed.), The handbook of Critical Theory (pp. 166-189). Cambridge: Blackwell Publishers Ltd.

Reich, W. (2007). Deliberative democracy in the classroom: A sociological View. Educational Theory, 57(2), 187-197. 
Richard, J., \& Anderson, D. (1998). University autonomy in twenty countries. Canberra: Commonwealth of Australia: Centre for Continuing Education, The Australian National University.

Richards, H., \& Schwartz, L. (2002). Ethics of qualitative research: Are there special issues for health research? Family Practice, 19(2), 135-139.

Rizvi, F., \& Lingard, B. (2010). Globalising education policy. Oxon: Routledge.

Robbins, D., Strydom, M., \& Hoosen, S. (2009). SARUA handbook 2009: A guide to the public universities of Southern Africa. Retrieved 12, 2010, from http://www.sarua.org/files/Handbook/full handbook.pdf

Robertson, S., Novelli, M., Dale, R., Tikly, L., Dachi, H., \& Alphonce, N. (2007). Globalisation, education and development: Ideas actors and dynamics. Bristol: Department for International Development: Educational Papers.

Rust, V., \& Jacob, J. (2005). Globalisation and education policy. In J. Zadja (Ed.), International handbook on globalisation, education and policy research (pp. 235-252). Dordrecht: Springer.

Rytmeister, C., \& Marshall, S. (2007). Studying political tensions in university governance: A focus on board member construction of role. Tertiary Education and Management, 13(4), 281-294.

Saint, W. (2004). Comments on challenges facing African universities. African Studies Review, 47(1), 61-65.

Saint, W. (2009). Legal frameworks for higher education governance in subSaharan Africa. Higher Education Policy, 22(4), 523-550.

Samoff, J., \& Carrol, B. (2003). From manpower planning to the knowledge era: World Bank policies on higher education. Paper presented at the UNESCO Forum on Higher Education, Research and Knowledge.

Samoff, J., \& Carrol, B. (2004a). Conditions, coalitions and influence: The World Bank and higher education in Africa. Paper presented at the Annual Conference of the Comparative and International Education Society, Salt Lake City. 
Samoff, J., \& Carrol, B. (2004b). The promise of partnership and continuities of dependence: External support to higher education in Africa. African Studies Review, 47(1), 67-199.

Sawyerr, A. (2004a). African universities and the challenge of research capacity development. JHEA/RESA, 2(1), 213-242.

Sawyerr, A. (2004b). Challenges facing African Universities. African Studies Review, 47(1), 1-59.

Sayed, Y., Mackenzie, I., Shall, A., \& Ward, J. (2008). Mainstreaming higher education in national and regional development in Southern Africa: A regional profile. Retrieved 24, 2009, from http://www2.aau.org/mrci/docs/sarua final.pdf

Shawa, L. B. (2007). Can higher education policy frameworks engender quality education in Malawian Universities? (Unpublished master's thesis). Stellenbosch University, Cape Town.

Sherman, M. (1990). The university in Modern Africa: Toward the TwentyFirst Century. The Journal of Higher Education, 61(4), 363-385.

Short, P. (1974). Banda. London and Boston: Routledge and Keagan.

Stewart, F., \& Wang, M. (2003). Do PRSPs empower poor countries and disempower the World Bank, or is it the other way round? Oxford: University of Oxford, Queen Elizabeth House.

Sturges, P. (1998). The Political economy of information: Malawi under Kamuzu Banda. International Information and Library Review, 30, 185201.

Taylor, J., \& Miroiu, A. (2002). Papers in higher education: Regional university network on governance and management of higher education in South East Europe. Bucharest: UNESCO.

Teferra, D., \& Altbach, P. (2004). African higher education: Challenges for the 21st century. Higher Education, 47(1), 21-50.

The University of Malawi. (1998). The University of Malawi Act (1974) incorporating the Amended Act of 1998. Zomba: The University Office. 
The University of Malawi. (2004). The University of Malawi Strategic Plan 20052010. Zomba: The University of Malawi.

The University of Malawi. (2009). The University of Malawi ACT (proposed). Zomba: The University of Malawi.

Thomas, E., \& Magilvy, J. (2011). Qualitative rigor or research validity in qualitative research. Journal for Specialists in Pediatric Nursing, 16, 151-155.

Tilak, J. (2005). Are we marching towards laissez-faireism in higher education development? Journal of International Cooperation in Education, 8(1), 153-165.

Tomal, D. (2003). Action research for educators. Lanham: The Scarecrow Press, Inc.

Trowler, P. (1998). Education Policy. Eastbourne: The Gildredge.

Vail, L., \& White, L. (1989). Tribalism in the political history of Malawi. In L. Vail (Ed.), The creation of tribalism in Southern Africa (pp. 152-184). London: Currey University of California Press.

Van Vught, F. (1994). Autonomy and accountability in government/university relations. In J. Salmi \& A. Verspoor (Eds.), Revitalising higher education (pp. 322-362). Oxford: Pergamon Press.

Van Wyk, B. (2006). Exploring constitutive meanings of educational transformation in South Africa. Interchange, 37(181-199).

von Soest, C. (2007). How does neopatrimonialism affect the African state? The case of tax collection in Zambia. Journal of Modern African Studies, 45(4), 621-645.

Waghid, Y. (2003). Democratic Education: Policy and praxis. Stellenbosch: Department of Education Policy Studies.

Waghid, Y. (2004). Deliberative democracy and higher education policy discourses in South Africa: In defence of equitable redress. In Y. Waghid \& L. le Grange (Eds.), Imaginaries on democratic education and change (pp. 31-40). Pretoria: SAARDHE. 
Waghid, Y. (2005). On the possibility of cultivating justice through teaching and learning: An argument for civic reconciliation in Africa. Policy Futures in Education, 3(2), 132-140.

Waghid, Y. (2006). University education and deliberation: In defence of practical reasoning. Higher Education, 51(Springer), 315-328.

Weaver, K., \& Olson, J. (2006). Understanding paradigms used for nursing research. Journal of Advanced Nursing, 53(4), 459-469.

Whittemore, R., Chase, S., \& Mandle, C. L. (2001). Validity in qualitative research. Qualitative Health Research, 11(4), 522-537.

Whitty, G., Power, S., \& Halpin, D. (1998). Devolution and choice in education: The school, the state and the market. Buckingham: Open University Press.

Williams, D. (1978). Malawi: The Politics of despair. Ithaca and London: Cornell University.

Williamson, J. (2004). A short history of the Washington Consensus. Paper presented at the From the Washington Consensus towards a new Global Governance conference, Barcelona.

Willis, J., Jost, M., \& Nilakanta, R. (2007). Foundations of qualitative research: Interpretive and critical approaches. Thousand Oaks: Sage.

World Bank. (2009). Accelerating catch up: Tertiary education for growth in sub-Saharan Africa. Washington DC: World Bank.

Yates, S. (1998). Doing social research. London: SAGE.

Zeilig, L. (2009). Student resistance and the democratic transition: Student politics in Senegal 1999-2005. Social Dynamics, 35(1), 68-93.

Zeilig, L., \& Dawson, M. (2008). Introduction: Student activism, structural adjustment and democratic transition in Africa. JHEA/RESA, 6(2 \& 3), 131.

Zeleza, P. T. (2003). Academic freedom in the neo-liberal order: Governments globalisation, governance and gender. JHEA/RESA, 1(1), 149-194. 
Zeleza, P. T. (2005). Transnational education and African universities. JHEA/RESA, 3(1), 1-28. 


\section{APPENDICES}

Appendix 1: An example of an invitation letter for research

\section{VICTORIA UNIVERSITY OF WELLINGTON \\ Te Whare Wananga o te Upoko o te Ika a Maui}

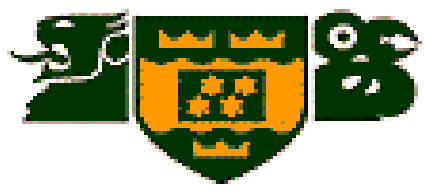

\section{Work Address}

Lester Brian Shawa,

Department of Education and Teaching Studies

Mzuzu University, P/Bag 201, Mzuzu, Malawi

Email: brianshawa2001@yahoo.com

Ph (+265) - 1- 320 - 579 (575); Mobile (+265) - 88-453-2348

\section{$\underline{\text { School Address }}$}

Lester Brian Shawa, PhD candidate

Victoria University of Wellington

PO Box 600, Wellington 6140, New Zealand

Email: brian.shawa@vuw.ac.nz

Ph (+64-4-463 9851); Mobile (+64-210-299 4695)

Dear [Sir/Madam/Prof/ Dr/ Mrs/Miss/ Mr/ Fr/ Rev]

\section{INVITATION TO PARTICIPATE IN RESEARCH}

I would like to invite you to participate in my doctoral research as detailed in the information sheet attached.

I am a Lecturer in Education and Teaching Studies at Mzuzu University currently pursuing Doctoral studies in Education at Victoria University of Wellington in New Zealand. As part of this degree, I am undertaking research using critical theory to investigate university policy-making and practice in 
Malawi. My PhD research is supervised by Dr. Stephanie Doyle and Prof. Rob Strathdee, both at the Faculty of Education, Victoria University of Wellington.

Please also find attached a consent form and a research information sheet.

Your assistance shall be greatly appreciated.

Yours faithfully,

Lester Brian Shawa

PhD Candidate, Victoria University of Wellington, New Zealand Lecturer, Mzuzu University 


\section{VICTORIA UNIVERSITY OF WELLINGTON \\ Te Whare Wananga o te Upoko o te Ika a Maui

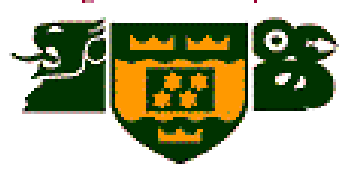

\section{CONSENT TO PARTICIPATE IN RESEARCH}

\section{Exploring anti-democratic practices in university policy-steerage, management and governance in Malawi: A Critical Theory approach}

Researcher: Lester Brian Shawa, Faculty of Education, Victoria University of Wellington.

I have been given full information about this research and I have understood an explanation of the research project. I have had an opportunity to ask questions and have them answered to my satisfaction.

I understand that the information provided will be used for the purposes of this $\mathrm{PhD}$ research, academic papers and conference papers only.

I understand that I may withdraw (or any information I have provided) from this research (before data collection and analysis is complete) without having to give reasons or without penalty of any sort.

I understand that if I withdraw from the project, my interview transcript will be returned to me or destroyed.

I understand that I will not be named in the report but my organisation will be.

I understand that the researcher will be the sole transcriber of the work and that the researcher will replace names of respondents with codes in the transcripts. 
I understand that all transcripts will be kept in a locked file and access will be restricted to the investigator and supervisors.

I understand that I will be given opportunity to check transcripts of my interview.

I understand that the tape recording of the interview will be electronically wiped at the end of the research.

I would like to receive a summary of the research findings.

I would like to be provided with an electronic link to the final $\mathrm{PhD}$ thesis.

Name of the [Organisation]

Name of the [Respondent]

Position/Role of the [Respondent]

Signed [Respondent]

Date 


\section{VICTORIA UNIVERSITY OF WELLINGTON \\ Te Whare Wananga o te Upoko o te Ika a Maui}

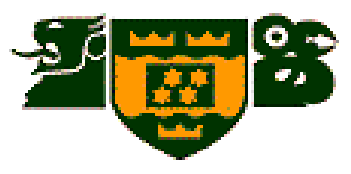

\section{RESEARCH INFORMATION SHEET: Ministry of Education and Vocational Training (MoEVT) and Ministry of Economic Planning and Development (EP\&D)}

Exploring anti-democratic practices in university policy-steerage, management and governance in Malawi: A Critical Theory approach

Researcher: Lester Brian Shawa, Faculty of Education, Victoria University of Wellington.

I am a Lecturer in Education and Teaching Studies at Mzuzu University currently pursuing Doctoral studies in Education at Victoria University of Wellington in New Zealand. As part of this degree, I am undertaking research using critical theory to investigate university policy-making and practice in Malawi. My PhD research is supervised by Dr. Stephanie Doyle and Prof. Rob Strathdee.

In keeping with the university's human ethics policy, I have sought and gained ethical approval from the Faculty of Education's Human Ethics Committee.

The research uses Critical Theory to examine the formulation and implementation of university policy in Malawi with specific reference to issues of equity, social justice, creativity and academic freedom.

The researcher will interview leaders of selected organisations including universities, two government ministries, staff and students unions and World Bank and International Monetary Fund, and will analyse policy documents.

I hope my thesis and associated reports will provide valuable information to policymakers, academics, higher education scholars, human rights activists and bodies that advance values of democratic governance, deliberative democracy and citizenship education. 


\section{What does this research involve?}

With their consent, the research will involve a recorded in-depth interview with the Principal Secretary and the Director of Higher Education at MoEVT and the Director of Development at EP\&D that I will later transcribe. The interview will take approximately one hour.

\section{What will I do to ensure your institution's privacy?}

All interviews with respondents will be kept confidential and will only be used for purposes of this PhD study and for academic publications. Interview transcripts will be retained for five years. All audio recordings will be wiped at the end of the project. Although organisations, union groups, government ministries and institutions will be named in the study no information will be attributed to individuals. I will be the sole transcriber of the work I will replace names of respondents with codes in the transcripts. Respondents will be given opportunity to check transcripts or excerpts and I will keep all transcripts in a locked file.

All respondents' institutions will be provided with a written summary of the findings and if requested an electronic link to the final $\mathrm{PhD}$ thesis.

If you require further information or clarification on any of the above points, please do not hesitate to contact me or my supervisors (details below):

My contact details

\begin{tabular}{|c|c|}
\hline Work Address & $\underline{\text { School Address }}$ \\
\hline $\begin{array}{l}\text { Lester Brian Shawa, } \\
\text { Department of Education and } \\
\text { Teaching Studies } \\
\text { Mzuzu University, P/Bag 201, Mzuzu, } \\
\text { Malawi } \\
\text { Email: } \\
\text { brianshawa2001@yahoo.com } \\
\text { Ph (+265) - 1- 320-579 (575); } \\
\text { Mobile (+265) - 88-453-2348 }\end{array}$ & $\begin{array}{l}\text { Lester Brian Shawa, PhD candidate } \\
\text { Victoria University of Wellington } \\
\text { PO Box 600, Wellington 6140, New } \\
\text { Zealand } \\
\text { Email: brian.shawa@vuw.ac.nz } \\
\text { Ph (+64-4-463 9851); Mobile (+64- } \\
\text { 210-299 4695) }\end{array}$ \\
\hline
\end{tabular}


Supervisors' Contact details

\begin{tabular}{|l|l|}
\hline Dr. Stephanie Doyle, & Prof. Rob Strathdee \\
Victoria University of Wellington & Victoria University of Wellington \\
PO Box 17-310, Karori, Wellington & Po Box 600, Karori, Wellington \\
New Zealand & New Zealand \\
Phone: +64-4-463-6657 & Phone: +64 44637468 \\
Cell: +64 272841084 & Cell: +64275637468 \\
Fax: + 64-4-4639521 & Fax: +64 4 4635349 \\
Email: stephanie.doyle@vuw.ac.nz & Email: $\underline{\text { rob.strathdee@vuw.ac.nz }}$ \\
\hline
\end{tabular}


1. Can you describe decision making processes at this university?

2. What major problems do you face in decision making processes at this university?

3. Debates on African higher education show a proliferation of problems within the running of universities in Africa, what challenges does your university face?

4. What major policies do you have in running this university? How were the policies arrived at?

5. In what ways can staff members and students advance their concerns to the university administration/management?

6. Most Governments in Africa have been criticised for the neglect of students and staff welfare in their universities, what has been your experience?

7. Some policy analysts have argued that although having state presidents as chancellors of universities was meant to link higher education and development in most African countries, the arrangement has exacerbated tension between states and universities. What has been the experience in Malawi?

8. Current debates on African higher education show that there is a need for academic freedom in universities, how does this university ensure academic freedom among staff and students?

9. How do you implement government policy initiatives for the university?

10. What other wider local and international community influence education policy in Malawi?

11. What kind of changes and vision do you have to improve higher education and policy-making in Malawi both at national and university levels? 


\section{Appendix 5: Sample questions for chairpersons of staff unions}

1. Debates on African higher education show a proliferation of problems within the running of universities in Africa, what challenges does your staff union experience?

2. In what ways can staff members advance their concerns to the university administration /management?

3. Most Governments in Africa have been criticised for the neglect of students and staff welfare in their universities, what has been your experience?

4. Current debates on African higher education show that there is a need for academic freedom in universities, how does your university ensure academic freedom among staff members?

5. Some policy analysts have argued that although having state presidents as chancellors of universities was meant to link higher education and development in most African countries, the arrangement has exacerbated tension between states and universities. What has been your experience?

6. What kind of changes and vision do you have to improve higher education and policy-making in Malawi? 


\section{Appendix 6: Sample questions for chairpersons of student unions}

1. How would you describe the role of the students union at this university?

2. What critical issues or challenges do you experience at this university?

3. What are the major causes of riots or strikes at this university?

4. In what ways does your student body advance your concerns to the university administration/management?

5. As a student body in what ways do you make sure that a creative and an academic inquiring spirit prevails among students?

6. What changes do you suggest in order for this university to operate better? 


\section{Appendix 7: Questions for the Director of Development}

1. What input does your ministry have in development policy and the role of higher education in Malawi?

2. Describe the different groups or individuals who have contributed to development policy and in what ways has the Malawi government responded

3. In your view, what has been the impact of different policy initiatives on development policy in Malawi?

4. Some policy analysts have argued that although having state presidents as chancellors of universities was meant to link higher education and development in most African countries, the arrangement has exacerbated tension between states and universities. What has been your experience?

5. What challenges or opportunities for the future do you envisage in linking development policy to higher education? 


\section{Appendix 8: Sample questions for university registrars and principals}

1. How can you describe the role of government in running the university?

2. What specific challenges do you experience while working with the government?

3. Recent government policies have included issues of quality, relevance, equitable access, and governance within the universities. How has the university been involved in government higher education policy formulation?

4. What other wider local and international community influence policy at this college?

5. Can you describe decision-making processes at the university?

6. In what ways are students involved in decision-making at the university?

7. In most sub-Saharan universities, research reveals a lot of strikes or riots from both academic staff and students. What has been the experience at the University of Malawi?

8. In what ways can staff members and students advance their concerns to the university administration/management?

9. One of the major policies that have attracted public interest is the quota system of university selection. How has your office been involved in arriving at this policy?

10. Most Governments in Africa have been criticised for the neglect of students and staff welfare in their universities, what has been your experience?

11. Current debates in African higher education show that there is a need for academic freedom in universities, how does your college ensure academic freedom among staff and students?

12. Some policy analysts have argued that although having state presidents as chancellors of universities was meant to link higher education and development in most African countries, the arrangement has exacerbated tension between states and universities. What has been the experience in Malawi?

13. What kind of changes and vision do you have to improve higher education and policy-making in Malawi? 


\section{Appendix 9: Questions for the Director of Higher Education}

1. What are the major policy initiatives that have taken place in university education since 1995 ?

2. As a ministry, what current priorities or political drives influence university education policy in Malawi?

3. Describe the different groups or individuals who have contributed to higher education policy-making and in what ways has the Malawi government responded?

4. How do you monitor whether universities are fulfilling government policy initiatives?

5. Some policy analysts have argued that although having state presidents as chancellors of universities was meant to link higher education and development in most African countries, the arrangement has exacerbated tension between states and universities. What has been your experience?

6. Most Governments in Africa have been criticised for the neglect of students and staff welfare in their universities, what has been your experience?

7. Current debates in African higher education show that there is a need for academic freedom in African universities, how does your ministry ensure academic freedom in Malawian universities?

8. In your view, what has been the impact of different policy initiatives on the university sector in Malawi?

9. What kind of changes and vision do you have to improve higher education and policy-making in Malawi? 


\section{Appendix 10: Sample questions for vice chancellors, private universities}

1. Can you describe decision-making processes at this university

2. What major problems do you face in decision-making processes at this university?

3. Debates on African higher education show a proliferation of problems within the running of universities in Africa, what challenges does your university face as a private university?

4. What major policies do you have in running this university? How were the policies arrived at?

5. In what ways can staff members and students advance their concerns to the university administration/management?

6. Most Governments in Africa have been criticised for the neglect of students and staff welfare in their universities, what has been your experience?

7. Some policy analysts have argued that although having state presidents as chancellors of universities was meant to link higher education and development in most African countries, the arrangement has exacerbated tension between states and universities. What has been the experience in a church run university?

8. Current debates on African higher education show that there is a need for academic freedom in universities, how does this university ensure academic freedom among staff and students?

9. What role does the government play in assisting your private university?

10. How is your participation in policy-making at national level?

11. What other wider local and international community influence education policy in your context?

12. What do you understand by the quota system of section in public universities?

13. As a church university do you have a percentage of your members to be accepted at the university?

14. What kind of changes and vision do you have to improve higher education and policy-making in Malawi both at national and university levels? 


\section{Appendix 11: Questions for the civil society}

1. How is your organisation involved in higher education policy in Malawi?

2. One of the policy issues in higher education in Malawi is the issue of equitable access to university education. As an organisation what would you comment on this issue?

3. The government now how outlined policies in higher education to deal with quality, relevance, governance, from civil society point of view do you think the government has enough mechanisms to achieve these policy issues within the universities?

4. How would you assess external influence on university policy/ and or domestic policy in general terms?

5. How can organisations like yours help to sensitise or assist in policymaking especially in higher education?

6. I have noticed that most NGOs in education focus on basic education. Why do you think there is general lack of interest in higher education? 
Appendix 12: University of Malawi selection by district, year and population from 2002-2008

\begin{tabular}{|c|c|c|}
\hline Northern region districts & $\begin{array}{l}\text { Number of students in } \\
2002-2008\end{array}$ & Population per district \\
\hline Chitipa & 257 & 179,072 \\
\hline Mzimba & 744 & 853,305 \\
\hline Rumphi & 350 & 169,112 \\
\hline Nkhatabay & 272 & 269,575 \\
\hline Likoma & 48 & 10,445 \\
\hline Karonga & 363 & 272,789 \\
\hline Total & 2,034 & $1,745,298$ \\
\hline \multicolumn{3}{|l|}{ Central region districts } \\
\hline Kasungu & 258 & 595,130 \\
\hline Lilongwe & 365 & $2,211,279$ \\
\hline Ntchisi & 95 & 224,098 \\
\hline Mchinji & 149 & 456,558 \\
\hline Dowa & 160 & 539,645 \\
\hline Dedza & 200 & 623,789 \\
\hline Nkhotakota & 98 & 301,868 \\
\hline Salima & 89 & 339,773 \\
\hline Ntcheu & 314 & 474,451 \\
\hline Total & 1728 & $5,766,591$ \\
\hline Southern region districts & & \\
\hline
\end{tabular}




\begin{tabular}{|c|c|c|}
\hline Balaka & 221 & 316,740 \\
\hline Blantyre & 291 & $1,210,431$ \\
\hline Chikwawa & 117 & 435,966 \\
\hline Chiradzulu & 187 & 290,946 \\
\hline Machinga & 104 & 488,705 \\
\hline Mangochi & 156 & 803,602 \\
\hline Mulanje & 233 & 525,429 \\
\hline Mwanza & 54 & 94,476 \\
\hline Neno & 30 & 108,897 \\
\hline Phalombe & 95 & 313,227 \\
\hline Thyolo & 234 & 587,455 \\
\hline Zomba & 387 & 582,040 \\
\hline Nsanje & 97 & 238,089 \\
\hline Total & 2,116 & $6,083,369$ \\
\hline
\end{tabular}

Source: University of Malawi, University Office 


\section{Appendix 13: Public Affairs Committee (PAC) press statement}

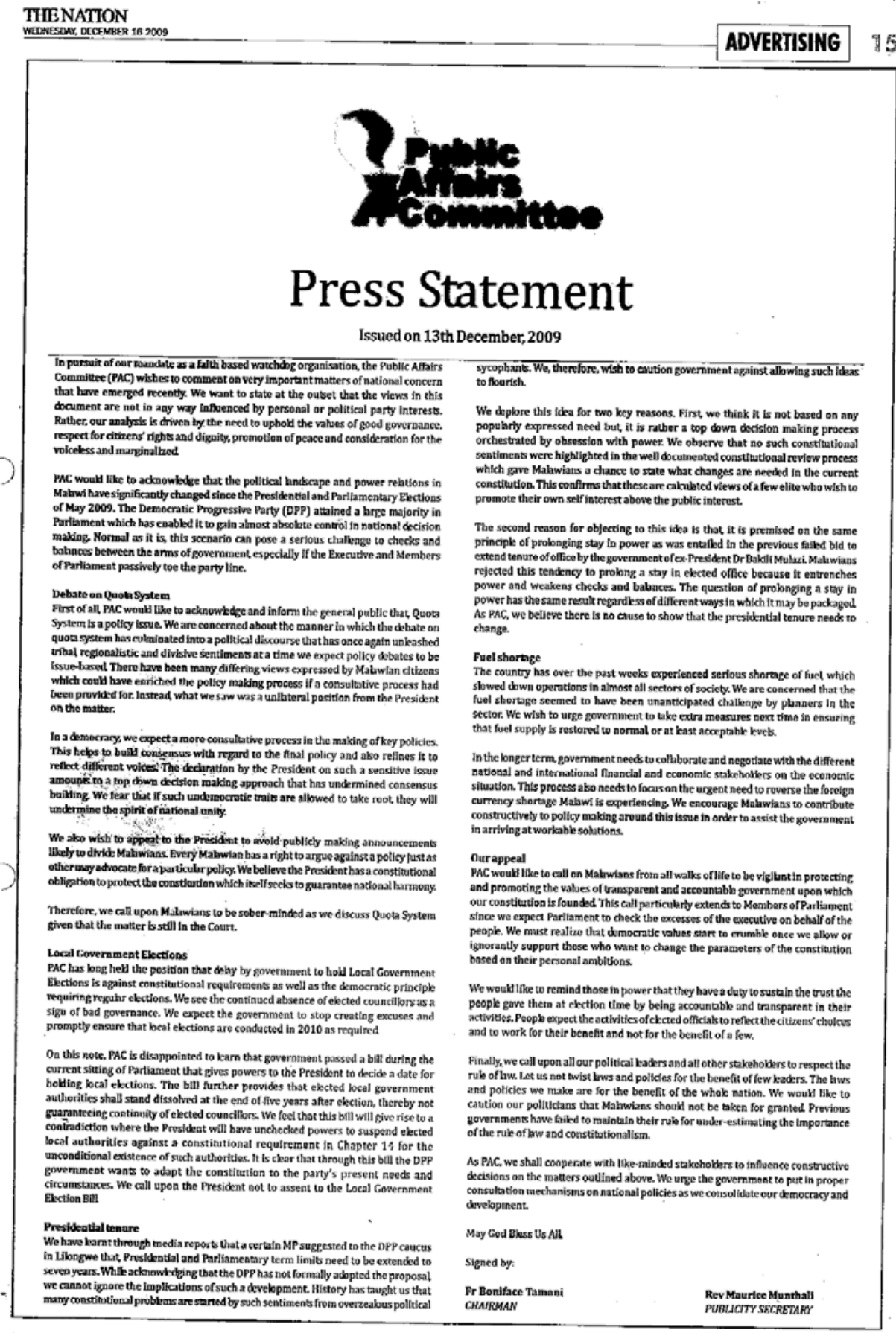




\section{Appendix 14: Church of Central Africa Presbyterian Synod of Livingstonia press release}

THE NATION

WEDNESDAY. SEPTEMBER 302009

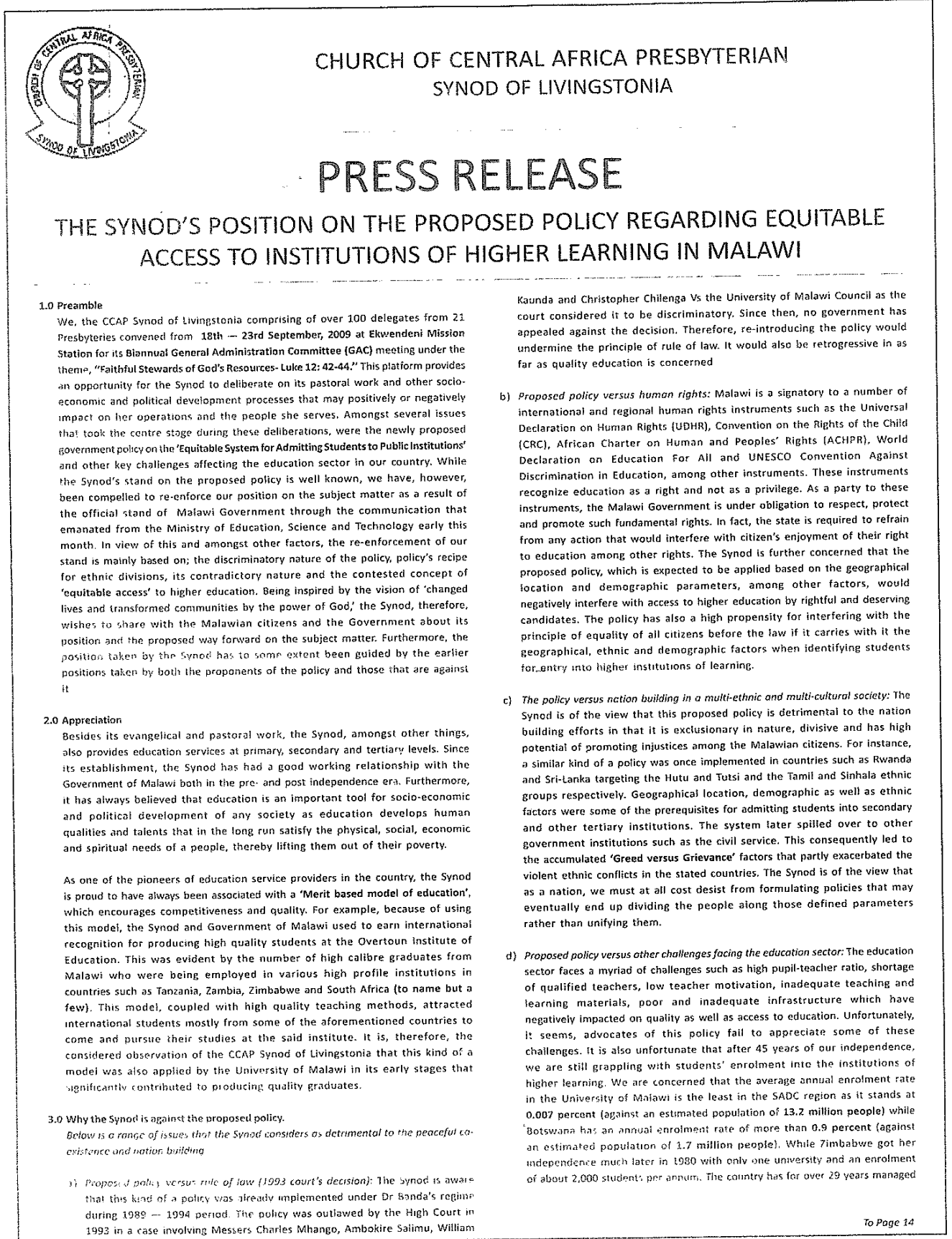


to build more than nine public universities with an annual enrollment rate. of more than 0.41 percent (measured against an estimated population of 12 million people).The Synod is, therefore, of the view that the proposed policy should not be used as a scapegoat for failing to develop institutions of higher learning in the country. Instead, as a nation, we should put all our energies, efforts and resources together to ensure functional education institutions and programmes that are available in sufficient quantity and quality and are accessible to all Maiawian citizens.

e) Policy versus existing system of rewarding best students: While the proposed existing system of rewording best students: while the propos policy may result in a more equitable distribution of oppor Malawians in ger the view that re-reintroducing this system could damage the educational prospects of many excellent students coming out of secondary school and, therefore, the system of rewarding the best students might, in the long run, be compromised.

f) Proposed policy versus the concept of 'equitoble access'. The Synod is of the view that the noncep' of 'equitable access' has not been clearly defined. It is

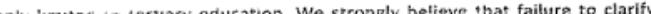
only this conced. (a) been

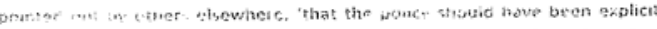

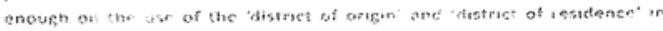
Identitymo andidates for entry into the inssitutions of higher learning since thest two terms are not necessarlly the same." "herefore, the correct term could have been used in order to convey the intended meaning.

4.0 Proposed Recommendations:

Bosed on the oforementioned, the CCAP Synod of Livingstonio, therefore recommends:

a) That the proposed policy should not be implemented as it is more likely to promote social divisions and derail the implementation of government programmes and policies.

b) That Malawi Government should concentrate on addressing the key challenges facing the education sector such as increased budgetary allocation. This would go a long way in addressing issues of high pupillecation. This would go a lone way in addressing issues of hish Thateriats, poor and inadequate infrastructure, among other issues.

c) That the state should be more open, transparent and accountable in formulating and implementing policies. Caution should be given to those policies that are considered insensitive and detrimental to nation building efforts and promotion of inter-group relations.

d) The Synod is urging the Government to always 'behave and act' within the Rule of Law. Our fear is that, the consolidation of democracy, protection and promotion of human rights would be under threat if the Rule of Law is promotion of human rights

$$
\text { Signed by: }
$$

Rev M.M. Banda (Moderator) Hot

Rey LN. Nyondo (General Secretary)

trastar

Rev M. c. E. Munthaî "Deputy General Secretary) 


\section{Appendix 15: Quota university policy selection directive}

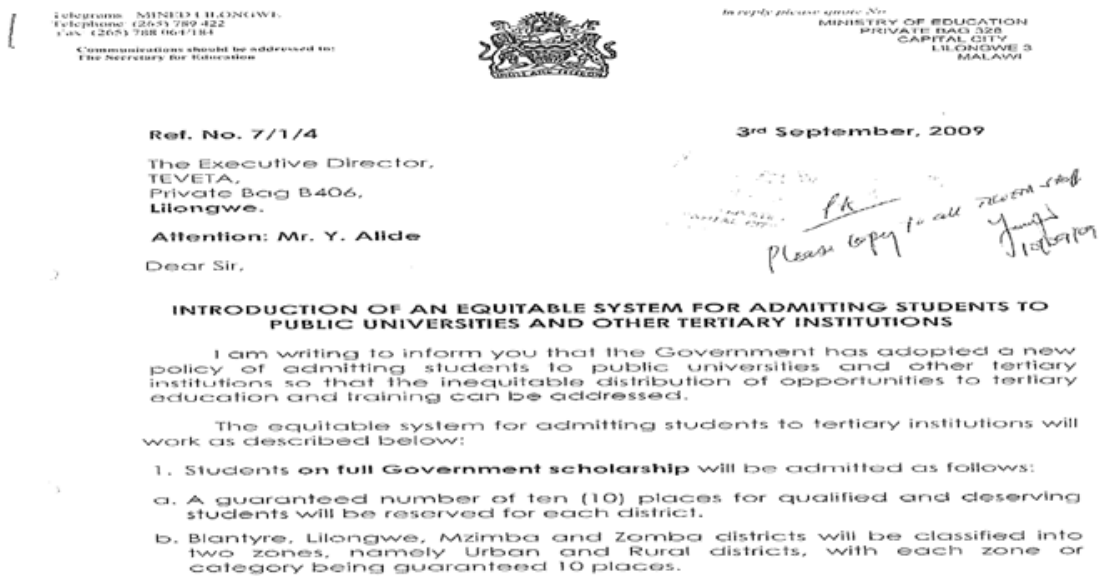

C. The balance of the available places will be distributed on merit basis according to population rations of districts of origin.

d. For the districts that would not be able to contribute a total of the remaining places would be put in inte the general pool and awards for such spaces would bo ro-distributed to other districts, based on the concernod.

2. Non-residential students (students not on govarnment scholarship)
will be admitted purely on meril and ability to pay, as is currently the caso.

You are, theretore, davised to imploment the new system with effec from the $2009 / 10$ academic year.

$$
\text { Yours faithfully. }
$$

SECRETARY FOR EDUCATION, SCIENCE AND TECHNOLOGY 


\title{
Appendix 16: call for academic freedom by top Malawian Professors
}

\author{
Malawi call for reform amid repression \\ University World News
}

24 April 2011

Issue: 0076

Leading Malawian professors have petitioned the government, proposing reform of the country's university system. This as academic freedom has come under severe threat, with the government firing teaching staff, freezing lecturer salaries, closing campuses and endorsing police planting of informants in university classrooms.

The professors, some of them teaching at top universities abroad, have petitioned the country's Education Minister Professor Arthur Mutharika (pictured) to set up a 16member commission to sit for six months with the objective of bringing about higher education reform.

They include Professor Sam Mchombo of the University of California, Berkeley, Professor Lupenga Mphande of Ohio State University's Department of African American and African Studies, Dr Louis Nthenda, formerly of the University of Malawi, Dr Mpalive-Hangson Msiska of Birkbeck College, University of London, and Thandika Mkandawire of the London School of Economics.

Malawian higher education was thrown into turmoil in January after Inspector General of Police Peter Mukhitho summoned University of Malawi political science lecturer, $\mathrm{Dr}$ Blessings Chinsinga, for questioning.

Chinsinga had allegedly made comments in class drawing parallels between problems encountered in Malawi and those that led to popular uprisings in Egypt and Tunisia.

Lecturers demanded an apology from the police officer and the government to reassure them that it upheld academic freedom. But President Bingu wa Mutharika said there was no need for the state agent to apologise, and accused lecturers of plotting to overthrow his government through "academic anarchy".

The issue sparked a strike by professors, and students joined in the protests. Three university campuses were subsequently closed and lecturers' salaries were frozen. A Malawian court has since 'unfrozen' the salaries, weeks after the president lost another court case against the lecturers through a verdict that said his decree for them to go back to work was null and void. 
The petition from the leading academics arrived as differences escalated. The professors said the commission's terms of references should include reviewing the current university law as it applies to the universities of Malawi, Mzuzu, Livingstonia, the Catholic University of Malawi and Blantyre International University.

It should recommend changes, examine the issue of academic freedom in all its ramifications, and investigate the pros and cons of establishing a University Grants Committee as a finance interface between the government, universities and management of the Endowment Fund.

In their proposal, the professors said for the past 50 years Malawian universities have operated under a one-party state, with university staff appointments, teaching materials and teaching content under the constant "threat of Big Brother".

They added that even though the one-party state was abolished nearly 15 years ago, old habits died hard. There have been attempts by the current government to influence appointments and determine teaching content and methods. They said this had reawakened in the collective academic memory the worst excesses of the 1970s and 1980s.

"As we approach the next 50 years, and with an increase in the number of universities, it is time to revisit and update the university law, especially as it pertains to academic freedom, internal administration, external relations and finding stable sources of financing," the proposal said.

The professors suggested that the Association of Commonwealth Universities (ACU), to which the University of Malawi belongs, as a neutral body acceptable to both sides should be requested to set up a 'blue ribbon' commission of inquiry drawn from member universities. ('Blue ribbon' refers to a group comprising eminent academics.)

The commission, they said, should comprise members seconded from the ACU's UK committee as well as Southern Africa, Australian and American university leaders, Malawian members appointed by the government, and Malawians recommended by university unions, among others.

They proposed that while the commission was sitting the parties should revert to the previous status: re-instate university teaching staff, reopen closed campuses and ensure that police desist from putting informants in university classrooms.

Meanwhile, the impasse has resulted in the Council for the Development of Social Science Research in Africa, or Codesria, postponing an international colloquium scheduled for Malawi in May due to "violations and abuses of academic freedom".

The colloquium, organised in conjunction with the University of Malawi and the South Africa-based Intellectual Heritage Project, has been organised to honour Malawi-born Mkandawire, one of the academics proposing the commission. 
"Chinsinga's class was infiltrated by informants hired by the Malawian state police, a practice reminiscent of the worst days of the Kamuzu Banda dictatorship. No modern university can properly function, let alone develop, under close police surveillance," Codesria said in a statement. 


\section{Appendix 17: Council for the Development of Social Science Research in Africa's concerns over academic freedom in Malawi}

CODESRIA cancels Malawi forum over academic freedom concern

By Nyasa Times

Published: April 11, 2011

Atop pan African intellectual think tank, the Council for the Development of Social Science Research in Africa (CODESRIA) has postponed an international Colloquium which was scheduled for Malawi in May due to "violations and abuse of academic freedom."

The Senegal-based pan-African organisation that promotes academic freedom as an integral part of the struggle for democracy and social justice, wanted to hold the academicians symposium in honour of a Malawi-born and one of Africa's finest academics Prof. Thandika Mkandawire.

"This event, organised by CODESRIA in collaboration with the University of Malawi and the South Africa-based Intellectual Heritage Project, was earlier scheduled to take place in his home country, Malawi, on 2-4 May 2011," said a statement posted on the organisation's website.

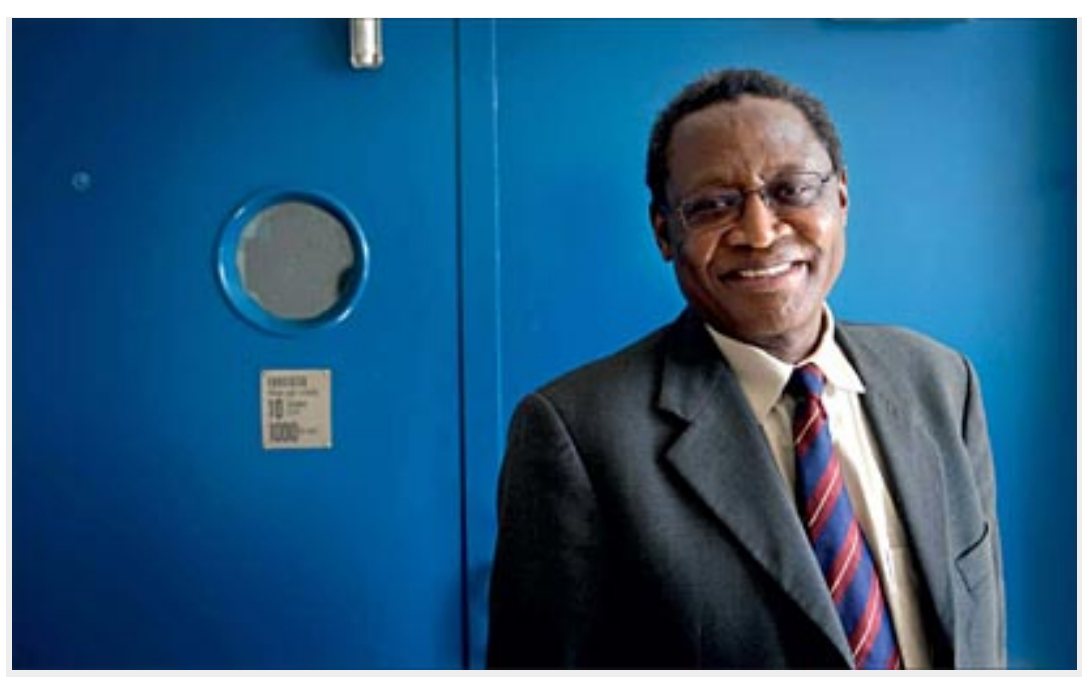

Prof Thandika Mkandawire:One of Africa's finest academics

Mkandawire, currently is Professor of African Development at the prestigious London School of Economics after having spent many years as Director of UNRISD in Geneva (1998-2009) and Executive Secretary of CODESRIA (1985-1996. 
"This great icon and proud son of Africa marked his 70th Birthday Anniversary last October," informed the statement. "For such a remarkable friend, inspiring leader and vigorous interlocutor for so many people, one who 'shared in our tribulations and triumphs', the occasion is not merely an anniversary of the birthday of an individual ; it is an opportunity us to celebrate a community that is as global as it is African."

CODESRIA said Malawi was ideal to hold the colloquium "in celebration of the life and works of Prof Mkandawire" with the University of Malawi as an ideal partner but that the recent "gross violations of academic freedom " at UNIMA give reason to organistaion to postpone the event.

The statement said the postponement will be up until "such a time when our Malawian colleagues feel less threatened in the exercise of their rights as scholars and the enjoyment of the freedom of research and expression, without fear of being persecuted because of their ideas."

Lecturers at UNIMA are currently protesting the infringement of their academic freedom after Inspector General of Police Peter Mukhito summoned Chancellor College political science professor Blessings Chinsingaover the contents of one of his class lectures in which he gave examples of reasons for popular protest taken from Egypt and Tunisia.

The lecturers have been boycotting classes demanding an apology and assurances of academic freedom from Mukhito, who has refused to apologise and has been backed by President Bingu wa Mutharika, who is both Chancellor of the University of Malawi and Commander-in-Chief of the Malawi Police Service.

CODESRIA and the entire community of African social researchers have since appealed to the Government of Malawi to take urgent steps to reinstate the academic staff of UNIMA who have been dismissed. The four lecturers, Chinsinga, Chancellor College Academic Staff Union president Dr. Jesse Kabwila-Kapasula, her Secretary General Franz Amin and Legal Advisor, Dr. Garton Kamchedzera, were dismissed but they have successfully obtained an injunction against the sackings in the High Court.

The organisation asked Malawi government to ensure that academic freedom is respected and guaranteed, in compliance with the Constitution of Malawi, and respond positively to the demand of the Chancellor College Academic Staff to assure them in writing that no such actions shall be repeated by any official authority, or agent connected with the Police.

"We hope the Council of the University of Malawi would also refrain from practices that make the academic staff of the university feel insecure," CODESRIA statement said.

Unima registrar, Benedicto Wokomaatani Malunga, told a local radio that there is no definition of academic freedom in Malawi.

Malunga, who is also secretary of University Council of Malawi, the regulatory authority of UNIMA said institution's senate has not agreed on what should be the definition of academic 
freedom and that the country's constitution does not clearly define it.-(Reporting by Thom Chiumia, Nyasa Times) 


\section{Appendix 18: Demonstration in fight for academic freedom at Chancellor College, University of Malawi}

Chanco set May 27 for academic freedom demo

By Nyasa Times

Published: May 24, 2011

Academic members of staff of Chancellor College (Chanco), a constituent college of the University of Malawi will on 27 May 2011 go to the streets and March marking 100 days of the fight in demand for academic freedom.

Apart from the march which will start at Chanco to Zomba City Centre and back, there will also be a news conference and later a documentary at Senior Common Room.

In a leaflet, signed by the Academic members of staff of Chancellor College entitled: '100 Days of the Academic Freedom Struggle in Defence of Constitutional Rights 16 February, 2011 - 27 February, 2011' which Nyasa Times has, the staff compare the present threat to academic freedom to that of the 70s, 80s and early 1990s when the University of Malawi was turned into a "reservoir for political detainees".

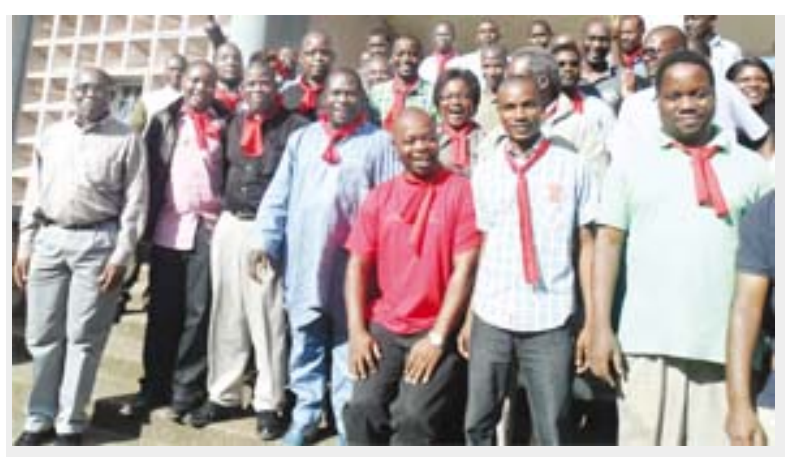

Lectures: Set May 27 for acedemic freedom march

The result, they write, was among others, "a massive brain drain that crippled the national University and has not been remedied."

Academic freedom is a constitutional right, they argue: "Section 44(1) and Section 45 of the Constitution of the Republic of Malawi state that there can be no limitation, restriction or derogation of academic freedom, not even during an officially declared state of emergency.

"The Constitution gives special protection to academic freedom because it is a necessary condition for the achievement of good quality education, freedom of thought and conscience, freedom of opinion, freedom of expression, access to and for the open pursuit and dissemination of information, which, in turn, is critical for national development," reads the leaflet signed by the Chanco Academic staff. 
They narrate that on 12 February 2011, an Associate Professor in the Department of Political and Administrative Studies a, Dr Blessings Chinsinga, was summoned by the Inspector General of the Malawi Police Service, Peter Mukhito, to an interrogation over the contents of a lecture that he had delivered to one of his classes.

But the members of the Chancellor College Academic Staff Union (CCASU) and other academic staff of the University considered the summoning of Chinsinga a gross violation of academic freedom as guaranteed by the Constitution of the Republic of Malawi.

They write that following the interrogation they together with the students, "out of fear of a repeat of the dark past," started to shun classes.

They petitioned the Police chief to among other things to seek assurance that no such actions shall be repeated by the Inspector General, personally, his agents, or any other authority connected with his office because they had created an unnecessary condition of censorship, fear, suspicion, and threat to the intellectual, professional and physical welfare of the academics.

They also asked him to apologise to the Chancellor College community "for the unnecessary disruptions in the academic calendar" and, to Chinsinga for the "psychological trauma caused to him personally and to his family".

Following this, to the "utter disbelief of the academics", Mukhito refused to apologise and was emphatic that academic freedom must be balanced against national security. He failed to give an assurance that this will not happen again.

President Bingu WA Mutharika, who is Commander-In-Chief of the police categorically, stated that the Inspector General will not apologise and he issued a directive that lecturers go back to lecture halls.

At several public rallies, the President, who is also Chancellor of the University of Malawi, pronounced the teaching of Chinsinga as bordering on treason and academic freedom as academic anarchy;

The University authorities summarily dismissed Chinsinga and Dr Jessie Kabwila-Kapasula (President of CCASU), Dr Garton Kamchedzera (legal Counsel of CCASU), and Mr Franz Amin (Secretary General of CCASU).

The University authorities further issued orders freezing all academic staff salaries and closing down Chancellor College and the Polytechnic colleges.

CCASU President Kabwila-Kapasula has also been received death threats.

Since then, the leaflet reads, the staff members have survived on court orders that have given them only temporary relief against the actions of the University authorities. 
Despite the courts pronouncements, the academic staff alleges that the Council of the University of Malawi continues to take destructive actions and is seeking to lift the court orders so that dismissals are effected and the two main colleges of the University are permanently closed and cordoned off by the police.

To the Academic staff, both the response of the Inspector General of Police and the actions of the University authorities indicate that spurious claims of national security maybe used to intimidate and victimise academic staff including students for things that they say in their academic work.

"This fear is genuine and informed by historical experience in which Chancellor College academic staff and students were detained without trial or victimized in many other ways merely for expressing themselves. There is real danger of reverting to the past."

The staff appeal for support "in solidarity for the defence of academic freedom in Malawi." (Reporting by Kumbukani Bwanali, Nyasa Times) 


\section{Appendix 19: Chairperson of the University of Malawi Council's view on academic freedom}

Academic freedom not under threat -Prof Seyani

By $\underline{\text { Nyasa Times }}$

Published: March 22, 2011

University Council of Malawi says academic freedom is not under threat saying the interrogation of political science associate professor Dr. Blessings Chinsinga, by Inspector General of Police Peter Mukhito didn't infringe upon academic freedom.

Prof. James Seyani, chairman of the University Council told a news conference in the capital, Lilongwe on Tuesday that it was necessary that the lecturers at Chancellor College in the eastern city of Zomba and Blantyre-based Polytechnic should "resume teaching by 24th March, 2011."

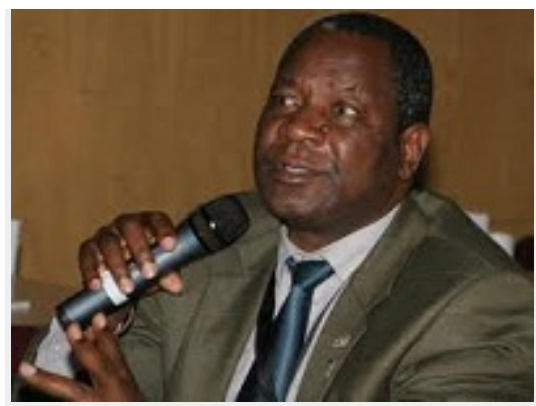

Seyani: No threats to academic freedom

"Academic freedom in the University of Malawi is assured, guaranteed and it not under threat," said Prof. Seyani said.

"The College Welfare Committees whose members have joined the Chancellor College sit-in are reminded of laid procedures which they have not followed," he said.

Associate Professor at the College of Medicine Dr. John Chisi has also challenged his fellow dons that their demand for academic freedom is uncalled for and should not disturb classes at the university.

"Why should a discussion between the IG and Chinsinga be a national problem? I cannot join the other lecturers who are abandoning classes because everybody is doing it," he said.

Chisi heaped praises for President Bingu wa Mutharika and his government and the Police chief saying these are doing great work to protect Malawians. 
"The IG has a duty to protect us. If he heard something that would pose threat to the security and went to ask Chinsinga is that wrong? I think the lecturers have taken this issue too far. They should state the real issues," he said.

Mukhito summoned Chinsinga after it was reported that the associate professor gave an example in class of the Middle East demonstrations. He reportedly said such demonstrations can be started if the economy is not fine. Chinsinga cited the shortage of fuel in Malawi as a possible cause for insurrections.

The lecturers demanded an apology from Mukhito for summoning their colleague. They also demanded an assurance from Mukhito that he will no longer poke his nose in the affairs of the university.

But President Mutharika said Mukhito will not apologise.-(Reporting by Charles Kufa, Nyasa Times) 